\title{
Representações, jornalismo e a esfera pública democrática
}

\author{
Murilo César Soares
}

SOARES, MC. Representações, jornalismo e a esfera pública democrática [online]. São Paulo: Editora UNESP; São Paulo: Cultura Acadêmica, 2009. 272 p. ISBN 978-85-7983-018-1. Available from SciELO Books <http://books.scielo.org>.

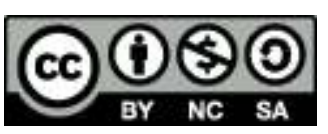

All the contents of this work, except where otherwise noted, is licensed under a Creative Commons Attribution-Non Commercial-ShareAlike 3.0 Unported.

Todo o conteúdo deste trabalho, exceto quando houver ressalva, é publicado sob a licença Creative Commons Atribuição Uso Não Comercial - Partilha nos Mesmos Termos 3.0 Não adaptada.

Todo el contenido de esta obra, excepto donde se indique lo contrario, está bajo licencia de la licencia Creative Commons Reconocimento-NoComercial-CompartirIgual 3.0 Unported. 


\section{REPRESENTAÇŌEs, JORNALISMO E A ESFERA PÚBLICA DEMOCRATICA}

MURILO CÉSAR SOARES 


\section{REPRESENTAÇÕES, JORNALISMO E A ESFERA PÚBLICA DEMOCRÁTICA}





\section{MURILO CÉSAR SOARES}

\section{REPRESENTAÇÕES, JORNALISMO \\ E A ESFERA PÚBLICA DEMOCRÁTICA}


(C) 2009 Editora UNESP

\section{Cultura Acadêmica}

Praça da Sé, 108

01001-900 - São Paulo - SP

Tel.: (0xx11) 3242-7171

Fax: (0xx11) 3242-7172

www.editoraunesp.com.br

feu@editora.unesp.br

CIP - Brasil. Catalogação na fonte

Sindicato Nacional dos Editores de Livros, RJ

\section{S653r}

Soares, Murilo César

Representações, jornalismo e a esfera pública democrática / Murilo

César Soares. - São Paulo : Cultura Acadêmica, 2009.

Inclui bibliografia

ISBN 978-85-7983-018-1

1. Jornalismo - Brasil. 2. Jornalismo - Aspectos políticos - Brasil.

3. Imprensa e política. 4. Democracia. 5. Cidadania. I. Título.

09-6213.

CDD: 079.81

CDU: 070(81)

Este livro é publicado pelo Programa de Publicações Digitais da Pró-Reitoria de Pós-Graduação da Universidade Estadual Paulista "Júlio de Mesquita Filho" (UNESP)

Editora afiliada:

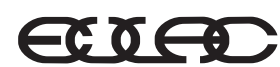

Asociación de Editoriales Universitarias de América Latina y el Caribe

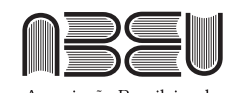

Associação Brasileira de Editoras Universitárias 


\section{SUMÁRIO}

Apresentação 7

PARTE I - Representações 11

1 Representações e comunicação: uma relação em crise 13

2 A luta pelo sentido: retórica e pensamento 29

3 Formas da representação jornalística 47

PARTE II - Democracia e jornalismo 71

4 Democracia: a palavra e os sentidos 73

5 Jornalismo e democracia, além das antinomias 103

6 O papel dos meios informativos nas lutas da cidadania 129

PARTE III - Verificações e análises 153

7 Cenários de representação da política nas eleições presidenciais brasileiras 155

8 Representações da reeleição pela imprensa 193

9 A crise política na esfera pública mediatizada 213 
10 Legitimidade e legalidade nos enquadramentos jornalísticos da campanha presidencial de 2006221

11 A luta pela democratização dos meios e as tecnologias digitais 239

PARTE IV - Balanço e perspectivas 261

12 O jornalismo na construção da esfera pública democrática 263 


\section{Apresentação}

Este livro foi organizado originalmente atendendo às exigências do concurso de livre-docência em Sociologia na Unesp. Ele é o resultado da reunião de textos tratando aspectos diversos das representações da política nas sociedades democráticas contemporâneas. A veiculação das representações pelos meios de comunicação têm um inegável impacto destes na construção social dos significados partilhados, em especial naqueles referentes à construção da democracia. Buscamos examinar a trajetória das representações nos planos individual, social e mediático, buscando, afinal, suas expressões nos processos políticos da vida democrática. Nessa perspectiva os meios são tomados como "uma arena de disputa entre representações do mundo social", na qual se veiculam discursos que conferem sentido à realidade, os quais "afetam a percepção dos cidadãos sobre sua própria realidade...” (Schramm, 2007, p.19).

A interpretação integral do papel do jornalismo na sociedade contemporânea, em termos de poder social de construção das representações, mobiliza conceitos teóricos num largo espectro, com diversos focos, constituindo um campo de estudos apoiado em bibliografia recente nacional e estrangeira (Reese; Gandy Jr.; Grant, 2001; Motta, 2002; Contrera; Figueiredo \& Reinert, 2004; Mccombs, 2004; Silva, 2006; Schudson, 2003; Entman, 2004; Curran, 2006). Não tivemos, 
porém, a pretensão de compor um exame sistemático do problema, mas apenas examinar certas categorias de representações, a partir do pressuposto de que, na dinâmica social da comunicação, elas estabelecem entre si uma relação, ora de pertinência mútua, ora de ligação significativa.

A maioria dos textos (oito de 11) foi redigida ao longo dos anos de 2005 a 2007, exclusivamente para a livre-docência. Três textos resultaram da reedição de trabalhos apresentados anteriormente nas reuniões do GT de Comunicação e Política da Compós, comparecendo aqui substancialmente modificados e atualizados.

A maior parte dos textos foi apresentada nos seminários temáticos e grupos de trabalho da Compós, da Anpocs, da Alaic e da SBPP, recebendo inestimáveis colaborações e críticas, sendo que alguns mereceram publicação em periódicos de Comunicação. Também me beneficiei da discussão dos textos com estudantes do curso de pós-graduação em comunicação da Faac, o que o contribuiu para o aperfeiçoamento e desenvolvimento de novas ideias.

O conjunto de textos está dividido em três partes. A primeira parte, intitulada Representações, compõe-se de três textos, o primeiro dos quais - Representações e comunicação: uma relação em crise - apresenta a problemática da primeira parte, ao discutir os aspectos cognitivos das representações, sua produtibilidade social e sua expressão mediática. No segundo texto, A luta pelo sentido: retórica e pensamento, examinamos a forma pela qual a formulação retórica, ao elaborar representações, constrói significados capazes de influenciar o pensamento e as avaliações da "realidade", ou seja, do estado do mundo empírico, em especial nos seus aspectos social e político. Por fim, em Formas da representação jornalística, tratamos do agendamento e do enquadramento como processos de representação próprios do jornalismo, capazes de exercer uma influência sobre juízos políticos das audiências e dos leitores, conforme diversas pesquisas empíricas.

A segunda parte, denominada Democracia e Jornalismo, é formada por três textos, o primeiro dos quais, Democracia, a palavra e os sentidos, examina as acepções que o termo recebeu e suas resso- 
nâncias, colocando uma discussão que nos pareceu absolutamente imprescindível a um conjunto de textos que analisa exatamente a relação entre a comunicação e o regime democrático. O segundo texto, Jornalismo e democracia, além das antinomias, busca situar a controvérsia sobre o papel desempenhado pelo jornalismo no contexto democrático, em torno da pergunta: a atividade jornalística age a favor ou contra a plenitude democrática? O terceiro texto, O papel dos meios informativos nas lutas da cidadania, procura relacionar a trajetória da liberdade de imprensa com o desenvolvimento das gerações de direitos da cidadania.

A terceira parte, denominada Análises, é dedicada a verificações do papel dos meios de comunicação em processos políticos brasileiros recentes. Cenários de representação da política e eleições presidenciais no Brasil relaciona os cenários construídos pelos meios de comunicação durante as campanhas das cinco últimas eleições presidenciais. Representações da reeleição pela imprensa analisa as posições assumidas por textos do jornalismo opinativo da Folha de S. Paulo e de O Estado de S. Paulo, na discussão da emenda da reeleição. A crise política na esfera pública mediatizada e Democracia, legitimidade e legalidade nos enquadramentos jornalísticos da campanha presidencial de 2006 analisam as controvérsias entre coberturas jornalísticas de duas das crises políticas que eclodiram no primeiro governo de Lula. Procuramos, nesses textos sobre objetos distintos, dirigir um olhar analítico, seja para os contextos das campanhas eleitorais, seja para os enquadramentos jornalísticos dos temas políticos, procurando interpretar o seu papel na democracia brasileira. O último texto, $A$ luta pela democratização dos meios e as tecnologias digitais, enfoca os esforços realizados pela regulamentação e pela democratização dos meios de comunicação no Brasil, tratando de questões como concentração mediática e poder político, que dizem respeito principalmente ao poder simbólico da atividade jornalística.

Balanço e perspectivas, texto que fecha o volume, constitui um exame dos resultados das investigações realizadas e um esforço para formular algumas inferências gerais, relacionando as discussões teóricas às análises de situações concretas, trabalho complexo porque 
cada capítulo tem a sua especificidade. Buscamos formular neste texto derradeiro algumas interpretações e avançar hipóteses para trabalhos futuros sobre representações, comunicação e democracia, que compuseram nosso campo de investigações, sugerindo algumas linhas de investigação possíveis.

\section{Referências bibliográficas}

CONTRERA, M. S., FIGUEIREDO, R. R., REINERT, L. Jornalismo e realidade: a crise da representação do real e a construção simbólica da realidade. S. Paulo: Ed. Mckenzie, 2004.

CURRAN, J. Media and power. Londres/Nova Iorque: Routledge, 2006.

ENTMAN, R. Projections of power: framing news, public opininion and U.S. foreign policy. Chicago/Londres: The University of Chicago Press, 2004

MC COMBS, M. Setting the agenda. Cambridge: Polity Press, 2004.

MOTTA, L. G. Imprensa e poder. Brasília: Ed. da Universidade de Brasília, S. Paulo: Imprensa Oficial do Estado, 2002.

REESE, S. D., GANDY JR., O. H., GRANT, A. E. (Eds.) Framing public life: perspectives on media and our understanding of the social world. New Jersey/Londres: Lawrence Erbaum Associates, 2001.

SCHRAMM, L. D. Dilemas democráticos e midiáticos contemporâneos. In: ASSOCIAÇÃO NACIONAL DE PÓS-GRADUAÇÃO EM COMUNICAÇÃO SOCIAL, 31., Caxambu, 2007. Anais... Caxambu: ANPOCS, 2007. 1 CD-ROM.

SCHUDSON, M. The power of the news. Cambridge/Londres: Harvard University Press, 2003.

SILVA, M. O. da. Imagem e verdade: jornalismo, linguagem e realidade. S. Paulo: Annablume, 2006. 
PARTe I

REPRESENTAÇÕES 



\section{1 \\ REPRESENTAÇÕES E COMUNICAÇÃO: UMA RELAÇÃO EM CRISE ${ }^{1}$}

O tema das "representações" vem atraindo a atenção de pesquisadores, em trabalhos acadêmicos atuais, nos campos das ciências humanas e sociais, indo da Pedagogia à Comunicação, abrangência que se deve, provavelmente, ao fato de que todas as realizações humanas podem ser examinadas com base no conceito de representação. Trata-se de um conceito com uma longa trajetória teórica (Santaella \& Nöth, 1998) e que vem sendo "construído nas fronteiras da sociologia, psicologia e semiótica", como atentou França (in Pereira et al, 2004, p.14).

Este texto, com base na bibliografia, aponta justamente a diversidade disciplinar que envolve o conceito, procurando sua distinção ou aproximação de outras noções, com o objetivo de balizar sua aplicação nos estudos sobre a comunicação mediática. Para isso, dada a amplitude do objeto, entendemos que nele devem ser distinguidas, pelo menos, quatro ordens de problemas distintos, porém complementares, a saber: a) representação mental, b) determinantes sociais das representações, c) representações mediáticas e d) representação distribuída.

1 Publicado na revista Líbero, n.20, dezembro de 2007. 


\section{Representação mental}

O ponto de partida e um dos momentos mais importantes da elaboração do conceito de representação é a filosofia medieval, que introduziu o termo latino repraesentatio, usado ora para indicar uma imagem ou ideia, ora ambas as coisas, sugerindo uma "semelhança" com o objeto ou a coisa representada. Representar envolvia, portanto, a ideia de reapresentar algo então ausente como se estivesse presente, ou seja, tornar algo presente outra vez. Essa noção deu origem a uma variedade de teorias sobre a representação mental na filosofia medieval, indo até a época de Descartes.

Uma forma bastante comum de tratar a representação mental entre os filósofos medievais era tomá-la como algo semelhante à coisa representada, por exemplo, retratando-a, estabelecendo uma correspondência com os objetos representados. Outra maneira de explicar a representação mental é considerar que ela e o objeto covariam, de modo que se um está presente o outro também está. No século XII, quando se estabelece grande parte do vocabulário filosófico ocidental, aparece o sentido de representação mental como conceito, ao qual se atribui uma função semântica, por meio da qual ele pode ser signo de objetos. A representação mental poderia atuar como uma "palavra" mental, assumindo um papel linguístico, de modo que as representações podiam ser combinadas para formar conceitos mais complexos ou sentenças da linguagem.

O termo alcançou um uso frequente na filosofia, especialmente para referir-se ao conhecimento que podemos ter da realidade e, no século XVIII, Kant considerou a representação como o gênero do qual todos os atos ou manifestações cognitivas seriam espécies, atribuindo significação máxima ao termo, com a qual que foi usado a partir de então na linguagem filosófica (Abbagnano, 1982). Nessa perspectiva, o mundo cognoscível para nós é constituído por representações, as quais são marcadas pelas limitações de nossos sentidos e das nossas capacidades cognitivas. Contemporaneamente, as noções de representação mental e de intencionalidade tornaram-se objeto da filosofia da mente, que considera que o pensamento é um estado 
mental sobre algo diferente de si mesmo, apresentando, pois, uma natureza representacional.

Representação mental é tomada, por alguns autores, como um construto hipotético para explicar o funcionamento da mente. Como uma teoria da mente não poderia se basear apenas em representações não-conceituais, considera-se que as representações mentais se constituem por meio da abstração dos dados da experiência, formando conceitos generalizáveis, os quais, ao serem designados pelos signos linguísticos, tornam-se estáveis, permitindo uma estruturação proposicional. Em última análise, no entanto, o significado de uma palavra encontrar-se-ia sempre na representação mental que essa palavra exprime (Prado Júnior, 1961).

\section{A determinação social das representações}

A partir do século XIX, abre-se uma nova perspectiva de análise do problema das representações, enfocando não os processos de formação dos conceitos no interior da mente e suas relações semânticas com os objetos representados, mas o papel das estruturas sociais e conjunturas históricas na constituição das representações. Passa-se a considerar a possibilidade da produção social das ideias, por meio de elaborações discursivas, que sancionam percepções sobre coisas, pessoas, ideias, estados e processos. As sociedades instaurariam consensos mais ou menos amplos, podendo entrar em conflito com formulações concorrentes.

Iniciadores desse enfoque, Marx e Engels apresentaram uma teoria sobre o papel da sociedade na formação das ideias, utilizando o termo ideologia para referir-se à influência das estruturas sociais na formulação das representações vigentes em uma dada época histórica (Marx \& Engels, 1983). A análise invertia os termos convencionais de abordagem do problema da formação das ideias, acentuando o papel determinante dos modos de produção material dos meios de subsistência da sociedade na construção das representações: 
Em outras palavras, não partimos do que os homens dizem, imaginam e representam, tampouco do que eles são nas palavras, no pensamento, na imaginação e na representação dos outros, para depois chegar aos homens de carne e osso; mas partimos dos homens em sua atividade real, é a partir de seu processo de vida real que representamos também o desenvolvimento dos reflexos e das representações ideológicas desse processo vital. (Marx \& Engels, 1998, p.19-20)

Numa sociedade dividida em classes, a ideologia dominante, na abordagem marxista, é a ideologia da classe dominante, a única que tem meios para dedicar-se à produção de ideias. A ideologia dominante mascara a base produtiva real da sociedade e as relações entre as classes dominantes e dominadas, tendo, por isso, um caráter justificador da exploração, formulando explicações legitimadoras do status quo. Ideologias são, portanto, representações conceituais de caráter político que configuram a realidade social a partir do prisma de uma classe, destacando-se nesse processo a classe dominante. Como se origina em um segmento restrito da sociedade, a ideologia expressa um consenso limitado e particular sobre determinadas questões, rechaçando argumentos de outros setores sociais. Tornase, assim, uma forma de representação auto-alimentada, que tende a se isolar e a caracterizar um antagonismo agudo com formulações concorrentes.

No início do século XX, um dos pioneiros da Sociologia, Émile Durkheim, propôs o conceito de "representações coletivas" para indicar categorias de pensamento que traduzem estados das coletividades. Nessa formulação, a estrutura social seria determinante das categorias de pensamento, da mesma forma que essas categorias tenderiam a reproduzir simbolicamente a estrutura social (Mattedi, 2006). Nos anos 20 e 30 do século XX, começa a constituir-se um campo próprio de estudos das determinações sociais do conhecimento, que ganhou corpo principalmente a partir da obra de Karl Manheim, Ideologia e utopia, fundadora da Sociologia do Conhecimento. Trata-se de disciplina voltada para o estudo da construção social 
da realidade, ou seja, dos processos de interiorização e objetivação das representações do mundo por meio da socialização (Berger \& Lukman, 1983).

Na psicologia social, adquiriu importância o conceito de representações sociais, proposto por Moscovici em 1961, que se contrapõe à noção de "representações coletivas", excessivamente totalista, de modo a sublinhar preferencialmente as influências grupais, em sociedades com maior diversidade social e cultural. Ele entende por representações sociais proposições, explicações e conceitos originados nas comunicações interpessoais da vida cotidiana. São formas de familiarização com setores do mundo estranhos a nós, constituindo-se de "uma série de proposições que possibilita que coisas ou pessoas sejam classificadas, que seus caracteres sejam descritos, seus sentimentos e ações sejam explicados e assim por diante" (Moscovici, 2003, p.209-10).

$\mathrm{Na}$ discussão sociológica sobre as relações entre conhecimento e contexto social, é necessária referência ao pensamento de Michel Foucault, que tratou da caracterização dos discursos de cada época histórica por meio do conceito de episteme, com o qual ele designa as relações conceituais que estruturam os diferentes tipos de discurso em uma dada época intelectual (Mattedi, 2006). Para Foucault, existe uma regularidade entre os conceitos e escolhas temáticas dos falantes, que remetem a "formações discursivas", às quais se referem as falas individuais. Em sua abordagem, os enunciados singulares não são livres, neutros e independentes, mas fazem parte de uma série, integram-se num jogo enunciativo geral (Gregolim, 2006). Dessa forma, a obra de Foucault é indicativa de que a representação reprime a área da experiência que condena ao silêncio, ou seja, ele compreende o discurso como uma violência imposta às coisas (Farinaccio, 2004).

\section{Representações mediáticas}

Os autores marxistas e os sociólogos do conhecimento, via de regra, analisaram um mundo em que a comunicação era predominan- 
temente linguística e literária, marcada pelos discursos do livro, do jornal e do partido. Com a disseminação dos meios audiovisuais, na segunda metade do século XX, a questão das representações deixaria paulatinamente esse domínio ligado a ideias e doutrinas formuladas proposicionalmente e começaria a envolver cada vez mais as representações visuais e encenações mediáticas, nas quais os conceitos nem sempre são declarados, nem os argumentos são formulados claramente, estando, pelo contrário, implícitos em imagens visuais e estruturas narrativas mediáticas, sendo naturalizados pelo registro fotográfico, ao qual se adicionaram o movimento, os sons, as cores e a difusão eletrônica. Na comunicação mediática praticada hoje, é raríssimo encontrar expressões das próprias ideologias, comuns em livros e em jornais partidários: elas se manifestam de forma tácita, como vestígios ou traços implícitos em narrativas do jornalismo, da ficção, da publicidade e da propaganda.

Origens mais remotas do uso de representação para referir-se a formas sensíveis podem ser encontradas na linguagem medieval, que também atribuía ao vocábulo o sentido de imagem ou representação na arte ou estratégias de trazer algo à mente. Quintiliano foi um dos primeiros autores a empregar o vocábulo representação, dando-lhe o sentido de "ilustração vívida", instrumento da boa retórica, pela qual é como se o orador pintasse um quadro claro e convincente do assunto, falando de forma a trazer à imaginação dos ouvintes um imagem interior, reapresentando-a às suas mentes. Além isso, o termo ganharia importância na teologia cristã medieval, na qual a Eucaristia é a representação do sofrimento de Cristo, lembrando seu amor pela humanidade. O termo foi também empregado como tradução de mimesis, da obra de Aristóteles, para referir-se à representação externa, imitação, pintura, escultura e poesia.

A força da comunicação contemporânea tem sido atribuída às capabilidades expressionais dos meios de comunicação que, por meio das imagens e da palavra, conferem realismo, drama e intensidade afetiva às representações mediáticas. Na sua origem e etimologia, o conceito de representação evoca algum tipo de simulação das propriedades de objetos, eventos, processos e relações, com a finalidade 
de retratá-los, de modo que as representações teriam, para alguns autores, um caráter analógico. Os meios de comunicação modernos são a concretização tecnológica máxima da "representação" naquele sentido de uma reapresentação, a partir da semelhança, da figurativatividade da imagem, da simulação.

A similitude entre a imagem e o objeto confere um caráter testemunhal, uma verossimilhança e um realismo às representações visuais, especialmente a partir da fotografia, dando um ar de naturalidade e espontaneidade a essas formas. Essas características foram exponenciadas pelo cinema e, mais ainda, pela televisão, especialmente nas transmissões ao vivo, que agregaram à imagem visual o movimento, os sons da realidade e a simultaneidade. A crítica da cultura mediática tem, por essa razão, focalizado destacadamente a fotografia, o cinema e a televisão, no sentido de revelar o caráter construído de suas representações.

A ideia de representação, necessariamente, parte do reconhecimento do seu caráter produzido. No entanto, as marcas dessa produção podem ser obliteradas sutilmente, ficando invisíveis, tanto no caso dos discursos verbais como nas imagens fotográficas ou eletrônicas. Na história das pesquisas em comunicação, diversos autores enfocaram de maneiras diferentes esse tema, destacando os vieses implícitos nas representações, por meio de conceitos como enquadramento ou framing (Entman, 1991), mitologia (Barthes, 1980) e representação (Hall, 1997).

Como resultado da onipresença dos meios, a vida em sociedade, contemporaneamente, foi analisada como sendo constituída de duas situações distintas: a primeira, real, concreta, do cotidiano vivido; a segunda, imaginária, que se abre a partir da cultura de massa (Morin, 1976). Esta última transporta as pessoas para além do horizonte cotidiano, por meios virtuais, produzindo experiências vicárias de fatos não vivenciados diretamente e construindo representações tanto sobre sua experiência direta como sobre temas distantes do dia-a-dia dos membros da audiência. Como aparentam ser ou mesmo se apresentam como um retrato do mundo, essas representações instauram ou sancionam, homologam, naturalizam certos vieses, os quais, no 
âmbito discursivo, sugerem que esse é o modo de ser da sociedade representada, podendo servir para fixar ou confirmar estereótipos étnicos, sociais, de gênero, profissionais. Trata-se ora da instauração de padrões "normais" ou "modelos", ora de imagens pejorativas ou idealizadas de populações, categorias sociais, minorias etc.

Assim, a pesquisa das representações na cultura mediática tem como focos mais recorrentes de investigação as representações da mulher, de minorias e de etnias, embora, em princípio, qualquer assunto possa ser objeto de estudo. As representações aparecem no contexto discursivo como formas casuais, meras insinuações, "pistas" visuais, ou mesmo como "cenário" dado como "normal" ou "padrão", que acaba naturalizando a representação, especialmente com o auxílio da imagem fotográfica ou eletrônica. Os discursos, assim, produzem determinadas composições de imagens pictóricas ou dramatúrgicas, audiovisuais, aparentemente colhidas no mundo empírico, sem intervenção ativa de ninguém, as quais são elevadas à categoria de "representantes" de pessoas, situações, fatos. Por esse meio, as intervenções invisíveis do autor de um discurso são potencialmente capazes de influenciar de maneira sutil as percepções sobre pessoas, gêneros, grupos sociais e categorias, contribuindo, como dissemos, para o estabelecimento ou fixação de estereótipos.

As representações desempenham papéis distintos nos três grandes gêneros da cultura mediática: a ficção, a persuasão (publicidade comercial, propaganda política) e a informação (jornalismo).

Uma quantidade de estudos sobre representações tem como objeto telenovelas, séries de TV, filmes, produções ficcionais que atuam no âmbito da fabulação, produzindo um imaginário sem compromisso necessário com o mundo empírico e histórico, a partir de certas estruturas canônicas, estudadas desde a Antiguidade, que se repetem na dramaturgia, aparecendo claramente nas produções desse gênero. Por isso, muitas dessas produções constituem uma espécie de "jogo", trabalhando com alguns elementos fixos, que vão se recombinando. Apesar de se basearem na liberdade criativa dos autores, operando esquemas recorrentes, essas produções constroem representações 
tácitas sobre a realidade social, naturalizando as estruturas sociais vigentes, idealizando categorias e demonizando outras.

A publicidade constitui o gênero que financia toda a comunicação mediática e, por isso, seus objetivos são bem específicos, no sentido de despertar nas audiências o desejo de consumo de bens. A representação na publicidade organiza-se como retórica, trabalhando no sentido de semantizar mercadorias, como calçados, relógios, bebidas etc., aos quais atribui significados hiperbólicos (Peninou, 1976). Para isso, opera com elementos narrativos do gênero entretenimento, recaindo, geralmente, na reiteração do status quo, o que envolve a idealização de famílias felizes, sexualidade, beleza e juventude perpétuas.

O caso do jornalismo é o mais controvertido, do ponto de vista da propriedade e precisão das representações. Ou seja, aceita-se com certa naturalidade a ideia de que um comercial de TV ou um filme de ficção contenha representações construídas e tendenciais, mas é difícil admitir essa inclinação quando se trata de uma reportagem, devido à suposição de um compromisso ético e profissional desse gênero em estabelecer uma relação referencial com a realidade. No entanto, o jornalismo é necessariamente um relato particular dos acontecimentos, ou seja, uma narrativa construída sobre um aspecto do mundo selecionado.

Representações não são informações pontuais, tão somente. Por isso, o conceito de enquadramento (framing) vem sendo empregado para analisar como informações pontualmente corretas e verificáveis podem ser selecionadas, valorizadas, destacadas, omitidas ou atenuadas, relacionadas a outras, em reportagens complexas, de modo a produzirem representações diferentes de uma mesma situação, dentro do limiar de verossimilhança (Soares, 2006).

Segundo Entman (1991), ao fornecerem, repetirem e, portanto, reforçarem palavras e imagens que referenciam algumas ideias, mas não outras, os enquadramentos tornam algumas ideias mais salientes no texto, outras menos e outras inteiramente invisíveis. As orientações dos enquadramentos são difíceis de detectar, porque muitos artifícios podem parecer "naturais", simples escolhas de palavras ou imagens. A comparação com outros textos, no entanto, mostra que 
essas escolhas não são inevitáveis ou não-problemáticas, sendo, pelo contrário, modos de definir e interpretar os eventos. Para o autor, por meio da repetição, focalização e associações reforçadoras, palavras e imagens, o enquadramento torna uma interpretação básica mais rapidamente discernível e memorável do que outras. Os fatores essenciais do enquadramento são a seleção dos aspectos de uma realidade percebida e a saliência dada a eles, promovendo, assim, uma definição da situação, uma interpretação causal, uma avaliação moral (Entman, 1993).

\section{Representação distribuída}

Com base nas abordagens anteriores, estabelece-se uma controvérsia em torno das dimensões das representações - mental, social, mediática - em busca da resposta definitiva às perguntas sobre "onde está, afinal, a representação?” e "qual a sua natureza real?” Uma solução que vem se desenhando em estudos recentes busca superar esse dilema, apontando para a distribuição do conhecimento entre pessoas e artefatos, interpretando-o como situado simultaneamente em contextos físicos e culturais. Nessa perspectiva, a representação inclui tanto agentes humanos, seus padrões de comunicação e práticas, quanto os artefatos materiais, dispositivos e instrumentos que suportam a disseminação do conhecimento pelo sistema. Nessa abordagem, os meios internos (memória, experiência) entrelaçam-se com meios externos (dados, diagramas, gráficos, instrumentos, painéis). Não poderíamos mais manter clara a dicotomia entre representações internas e externas (Osbeck \& Nercessian, 2006).

Aplicada ao campo da comunicação mediática, a visão distributiva da representação pode realizar uma síntese entre os fatores racional-cognitivo, social e técnico envolvidos no processo, permitindo a superação de antagonismos entre abordagens, como, por exemplo, aquele que confronta, de um lado, as análises das mensagens e, de outro, a recepção, buscando estabelecer o momento da produção de sentido. As representações seriam consideradas como constituídas de 
redes de interação entre pessoas e artefatos (mensagens), nas quais o polo individual só é possível na presença dos polos social e o material. Uma concepção distributiva considera as representações mentais, os processos sociológicos e as representações mediáticas como instâncias que incidem umas sobre as outras e retroagem, de forma dinâmica.

\section{Crítica das representações}

Na interpretação dos enquadramentos ou retóricas da comunicação mediática, a perspectiva de representação distribuída pode ser um instrumento de crítica dos meios. Como as representações mediáticas têm uma correspondência variável com estados do mundo, especialmente do mundo social, o seu cotejo com outras representações, da ciência ou do senso comum, permite aplicar, para variações que excedam um limite ou intervalo aceitáveis, a ideia de desrepresentação. As representações da mulher na publicidade, por exemplo, são, via de regra, irrealistas, comparadas a padrões populacionais regulares, sendo, no entanto, construídas como se fossem tipos estatisticamente frequentes. A partir de certo ponto, é mais adequado empregar o termo "mitos", proposto por Barthes (1990), utilizado para essa inflexão de sentido realizada pelos meios.

Mais crítico que a desrepresentação é o uso retroativo da representação mediática, no qual, em vez de ser considerada como substituto simbólico de algo, a representação é involuntariamente tomada pela audiência como o próprio objeto ou assunto representado, sendo usada como seu equivalente, numa verdadeira reificação da representação. Assim, a propaganda política é percebida como se fosse a própria política e não a encenação de uma forma de retórica eleitoral. De maneira semelhante, uma eventual ênfase na divulgação sistemática de crimes pela televisão pode ser interpretada pela audiência como sinal de uma elevação efetiva dos índices de criminalidade. Inversamente, deixar de dar uma notícia corresponde a fazer o acontecimento desaparecer para a audiência. 
As representações visuais são mais frequentemente objeto dessa involuntária reificação, tornando o critério contemporâneo de verdade a expressão “vi na TV” (Debray, 1993). Essa preocupação é o foco das meditações apocalípticas de Virilio (1994), que sugere que as imagens produzidas tecnologicamente alteraram o contexto nos quais os seres humanos experimentam, registram e recebem representações visuais, de modo que o olhar ocidental se tornou preso à tela, afastando as pessoas das experiências e ações reais, de fazer algo concreto e não mediatizado no mundo físico. A tela substitui o espaço público e o que é considerado verdadeiro passou a ser a imagem visual. As representações visuais tornam-se, assim, uma forma de controle oficial das representações, por meio da difusão de imagens seletivas sobre os acontecimentos, feita, por exemplo, por governos durante tempos de guerra. A condição de dependência das sociedades contemporâneas em relação às imagens tecnológicas leva uma ansiedade em relação ao presente, uma sensação de sermos esmagados pela tecnologia científica, uma inquietação sobre o poder político das imagens e uma demanda de que a representação se torne moralmente responsável (Barnhurst, 1996).

Focalizando especificamente o caso da imagem na televisão, Fiske (1996) relaciona três teorias críticas da representação: a mimética, a da representação ideológica e a pós-moderna. As duas primeiras têm em comum a crença de que exista uma realidade, a qual difere da imagem captada, ou seja, ambas as teorias argumentam que ocorre uma desrepresentação (misrepresentation), enquanto a terceira propõe o desaparecimento da própria representação. Na abordagem mimética, a realidade é definida em termos empíricos, sendo que a crítica focaliza os desvios da imagem, em comparação com imagens mais verdadeiras e acuradas do real. O problema epistemológico salientado na abordagem mimética é, assim, o da relação da TV com a realidade empírica. Já teoria da representação ideológica faz a crítica da construção da realidade pela televisão, cujo problema epistemológico é a discursividade ideologicamente determinada. A terceira abordagem enfocada por Fiske, que ele denomina teoria pós-moderna da televisão, está baseada no conceito de simulacro, 
proposto por Baudrillard (1991). Este autor ignora os problemas da desrepresentação e da construção, dizendo que imagens e realidade não têm status ontológicos diferentes, ou seja, que não há diferença entre imagem e realidade, pois vivemos numa era do simulacro.

O simulacro é tanto a reprodução como o original, a imagem e o referente, fundidos num mesmo conceito. Fiske exemplifica: quando um político faz uma declaração para uma câmara de TV, o político e seu comentário não ocorreriam sem as câmaras de TV, ou seja, o político e o comentário existem simultaneamente e de modo similar na tela da TV e na realidade. Não há diferença ontológica entre eles, nem há como dizer que um preceda ao outro: cada um é tão real e irreal quanto o outro. O simulacro não nega o real, mas sim a diferença entre a imagem e a realidade, já que vivemos uma hiper-realidade, uma situação em que se fundem imagem, realidade, espetáculo, sensação e significado. O hiper-real constituiria, ao mesmo tempo, a condição pós-moderna e nosso sentido de experiência dessa condição, reunidos numa mesma noção. Com isso, Baudrillard procura dar conta da característica da sociedade na época contemporânea: as imagens libertaram-se tanto da condição de mimese quanto da de representação, não podendo mais ser controladas pela realidade ou pela ideologia. A cultura pós-moderna é fragmentada, não estando organizada em proposições coerentes, segundo princípios estáveis. A perda de realidade e da ideologia como suportes das imagens seria outro aspecto da perda das chamadas grandes narrativas, levando à fragmentação da experiência e das imagens.

Fiske considera a televisão particularmente adaptada à cultura do fragmento, pelo fluxo contínuo de segmentos, numa sequência ditada pela mistura de requisitos narrativos, econômicos e do gosto popular. A fragmentação supera a tentativa de imprimir coerência ao discurso televisual e o controle remoto acrescenta novas fragmentações introduzidas pelo usuário, que praticamente constrói a programação que assiste. Mesmo o telejornal implica uma construção pós-moderna, ao justapor imagens de estúdio, o repórter ao vivo no local do acontecimento, imagens de arquivo, comentários de especialistas, reconstituições, infográficos. $\mathrm{O}$ acontecimento é um 
simulacro, no sentido de que se funde à sua própria representação, de que se espetaculariza por meio de uma série de recursos expressionais próprios dos meios, e essa condição passa a ser a sua maneira própria de existir para as audiências. Para Fiske, a sensibilidade pós-moderna não encara essa bricolage como contraditória - na medida em que dispensa conceitos organizadores como gênero, período ou meio, ela destrói a possibilidade de gerar contradições.

Portanto, por um lado o conceito de simulacro destaca a natureza das formas mediáticas, totalmente dependentes dos dispositivos tecnológicos que as produzem e confundidas com os recursos expressivos destes últimos. Por outro lado, sublinha o caráter fragmentário e aparentemente contraditório da comunicação mediática, caracterizada pelo fluxo permanente de imagens. Nessa perspectiva, dissolve-se o conceito de representação e até o de seu oposto, o de desrepresentação, substituídos por uma hiper-realidade autônoma. Trata-se de uma crítica radical, que nasce da consciência da fragmentação e do relativismo contemporâneos, instaurando um cenário de niilismo comunicacional (Machado, 2004). Essa perspectiva constitui um aspecto corrosivo da tecnologia sobre as bases tradicionais do pensamento representacional e um novo problema teórico para as teorias da representação. A nosso ver, uma forma de responder positivamente ao desafio do conceito de simulacro é a análise das comunicações mediáticas, deslindando seus paradoxos e fazendo a sua crítica.

Representações mediáticas fazem parte do ambiente cultural em que se dão o pensamento, julgamento e ação dos seres humanos. Embora, numa perspectiva distributiva, possam ser identificadas múltiplas agências de representação, como a escola, a ciência, o sindicato, para a maioria das pessoas, os meios são os provedores primordiais de representações sobre o estado da sociedade, da política, dos costumes, dos valores. Para fundamentar o desenvolvimento da sua crítica, contudo, parece-nos importante refinar ainda mais os marcos teóricos sobre a natureza e papel e limites das representações e do simulacro na cultura mediática e na vida social contemporâneas. 


\section{Referências bibliográficas}

ABBAGNANO, N. (1982). Dicionário de filosofia. São Paulo: Mestre Jou. BARNHURST, K. G. (1996) "Les frauduleux: science and the crisis of representation." Journal of Communication. Nova Iorque: v.46, iss.1. p.159-69.

BARTHES, R. (1990) O óbvio e o obtuso: ensaios sobre fotografia, cinema, pintura, teatro e música. Rio de Janeiro: Nova Fronteira. Mitologias. São Paulo: Difel, 1980.

BAUDRILLARD, J. Simulacros e simulação. Lisboa: Relógio d'Água, 1991.

BERGER, P., LUCKMAN, T. A construção social da realidade. Petrópolis: Vozes, 1990.

DEBRET, R. Curso de midiologia geral. Petrópolis: Vozes, 1993.

DICTIONARY OF PHILOSOPHY OF MIND. Disponível em:

$<$ http://philosophy.uwarterloo.ca/MindDict/representation.html>

ENTMAN, R. M. (1993) "Framing: Toward Clarification of a Fractured Paradigm." Journal of Communication 43 (4). p.51-8.

"Framing US coverage of international news: contrasts in narratives of the KAL and Iran Air incidents." Journal of Communications, 41 (4), 1991, p.6-27.

FARINACCIO, P. A questão da representação e o romance brasileiro contemporâneo. Campinas, 2004. Tese (Doutorado) - Universidade Estadual de Campinas, Instituto de Estudos da Linguagem.

FISKE, J. Post-modernism and television. In: CURRAN, J., GUREVITCH, M. (Eds.) Mass media and society. Londres/Sidney/Aukland: Arnold, 1996.

FRANÇA, V. R.V. Representações, mediações e práticas comunicativas. In: PEREIRA, M., GOMES, R. C., FIGUEIREDO, V. L. F. de. (Orgs.) Comunicação, representação e práticas sociais. Rio de Janeiro: Ed. PUCRio, Aparecida: Ideias e Letras. 2004, p.13-26.

FREIRE FILHO, J. "Força de expressão: construção, consumo e contestação das representações midiáticas das minorias.” Famecos, n.28, 2005, p.18-29.

GERARGHTY, C. (1996) Representation and popular culture. In: CURRAN, J., GUREVITCH, M. (Eds.) Mass media and society. Londres/ Sidney/Aukland: Arnold.

GREGOLIN, M. do R. Foucault e Pêcheux na análise do discurso: diálogos e duelos. S. Carlos: Claraluz, 2006. 
HALL, S. (ed.) Representation: cultural representations and signifying practices. Londres/Thousand Oaks/New Delhi: Sage, 2003.

MACHADO, A. A comunicação e sua retórica. In: PEREIRA, M., GOMES, R. C., FIGUEIREDO, V. L. F. de (Orgs.) Comunicação, representação e práticas sociais. Rio de Janeiro: Ed. PUC-Rio, Aparecida: Ideias e Letras. p.47-59, 2004.

MARX, K., ENGELS, F. A ideologia alemã. São Paulo: Martins Fontes, 1988.

MATTEDI, M. A. Introdução à abordagem sociológica do problema do conhecimento. Chapecó: Argos, 2006.

MORIN, E. Cultura de massas no século: o espírito do tempo. Rio de Janeiro: Forense-Universitária, 1975.

MOSCOVICI, S. Representações sociais. Petrópolis: Vozes, 2003.

OSBECK, L. M., NERCESSIAN, J. The distribution of representation. Journal of the Theory of Social Behaviour, v. 36. p.141-60, 2006.

PENINOU, G. Semiótica de la publicidad. Barcelona: Gustavo Gili, 1976. PRADO JÚNIOR, C. Notas introdutórias à lógica dialética. São Paulo: Brasiliense, 1961.

SÁ, C. P. Núcleo central das representações sociais. Petrópolis: Vozes, 1996.

SANTAELLA, L., NÖTH, W. Imagem, semiótica, mídia. São Paulo: Iluminuras, 1988.

SOARES, M. C. Análise de enquadramento. In: DUARTE, J., BARROS, A. Métodos e técnicas de pesquisa em comunicação. S. Paulo: Atlas, 2006. p.450-64.

SOARES, M. C. Construindo o significado do voto: retórica da propaganda política pela televisão. São Paulo, 1996. Tese doutoramento - USP.

Mensagens educacionais através do meio impresso. São José dos Campos, 1978. Dissertação de Mestrado - INPE.

STANFORD ENCYCLOPEDIA OF PHILOSOPHY. Disponível em: http://plato.stanford.edu.

VIRILIO, P. The vision machine. Londres: British Film Institute \& Indiana University Press, 1994. 


\section{2 \\ A lutA PELO SENTIDO: RETÓRICA E PENSAMENTO}

\section{Introdução}

A Retórica é uma das abordagens mais antigas da influência da linguagem sobre o pensamento. A partir do século XIX, ganha importância o estudo das ideologias políticas, entendidas como discursos originados da dinâmica das relações de classe, tendo papel relevante nos conflitos sociais e políticos. Buscamos as afinidades entre as duas noções, enquanto formas linguísticas de representação que, num contexto concorrencial, procuram influir na avaliação que as pessoas fazem de situações sociais concretas.

\section{A palavra mágica}

A origem mais remota da retórica, sugere Enriquez (1990), talvez se encontre na crença ancestral no poder propiciatório da linguagem, cujo fator essencial seria a característica operatória das palavras, que as tornaria capazes de, ao serem pronunciadas, transformarem a realidade, sem mediações. Vestígios dessa crença na magia da palavra podem ser observados, ainda hoje, nas atitudes das pessoas com relação às maldições, orações e às palavras-tabus. 
Mas não é toda linguagem que possui tal poder. Só uma linguagem encantada, enfeitiçada, artística, repetitiva (estruturada ritualmente) pode comportar tais efeitos mágicos. Esta linguagem remete à neurose narcísica dos indivíduos (e, portanto a seus desejos de onipotência), a reforça e fornece seu campo de aplicação. Favorece a posição maniqueísta, em que são projetadas sobre os adversários todas as características negativas. A análise de conteúdo dos discursos políticos mostra que eles pretendem menos demonstrar e argumentar, do que seduzir, atrair, fascinar por figuras de estilo, por variações de vozes, intensidade expressiva e, sobretudo, por repetições de fórmulas simples, que podem ser retomadas em coro pelo conjunto das massas. Os discursos funcionam como indicadores de ação e visam impedir qualquer reflexão contraditória. Neste caso, estamos no centro do funcionamento artístico, na medida em que este visa fascinar, transportar, fazer sonhar e fazer o sonho passar por realidade... (Enriquez, 1990, p.57-8).

Um recurso retórico básico é nomear coisas, fatos, situações, com sentido pejorativo ou elogioso. Dando nomes às coisas e aos fatos, o orador induz os ouvintes a se sentirem confiantes com um vocabulário prático para pensar e falar sobre as realidades tratadas (Hart, 1980). Esse aspecto lexical foi destacado num ensaio de Boyer (1991) sobre situações da política francesa, em que uma palavra, usada para denominar uma determinada política, se converte em um verdadeiro slogan para as necessidades do discurso estatal, argumentativo e autolegitimante. Os socialistas, por exemplo, assumiram o governo sob o signo da palavra solidariedade. Foi uma das palavras mais utilizadas desde a vitória de Mitterrand em 1981, servindo de nome a um ministério, o da Solidariedade Nacional. Solidariedade é um termo que se opõe a luta de classes, tendo um inquestionável valor moral, evocando de maneira menos conflitual os problemas da injustiça e da desigualdade, legitimando todo o esforço nacional de proteção social. Posteriormente, em 1982-3, é a palavra rigor que será investida do que Boyer chama de função encantatória do discurso oficial, substituindo o odiado apelo conservador à austeridade. Em 
1984, modernização, em princípio elitista, teria a mesma sorte. Mitterrand promoveria o princípio da "sociedade moderna, sociedade solidária”. Em 1988, reunião e abertura estiveram na ordem do dia da eleição presidencial, na estratégia de Mitterrand, em face da necessidade de co-habitação no governo entre socialistas e conservadores. O slogan era "a França unida". Quem recusará a reunião pela justiça social? Essa era a pergunta formulada por Mitterrand. A palavra abertura, em 1988, expressou o apelo do presidente aos ministros não-socialistas para a composição do seu novo ministério de coalizão.

O espetáculo das palavras na cena política é largamente dirigido por aqueles que detêm o poder e controlam o discurso estatal. Cada poder tem suas próprias palavras-slogans. No governo de J. Chirac, a denominação do ministério da Economia acolheu a nova palavra-slogan privatização e o nome do ministério dos assuntos sociais acrescentou a palavra emprego. A direita francesa também soube trabalhar a focalização das palavras evocando a liberdade para se relegitimar ideologicamente, em contraste com os socialistas, e reconquistar o poder em 1986.

Boyer conclui que o que ele denomina focalização léxico-pragmática, intensificada pela imprensa, é que conduz a essa autonomização do signo linguístico, produzindo a palavra-slogan. Esta última abandonaria o papel de mero designante, para participar da tentativa de empolgar a opinião pública, num contexto eminentemente conflitual. A discussão da fetichização da palavra ajuda-nos a compreender o processo político enquanto fenômeno retórico, em que à luta pelo poder deve corresponder uma luta pela linguagem.

\section{Demonstração, persuasão e sedução}

A Retórica, porém, não se resume às palavras isoladas, primeiro degrau do processo persuasivo, mas avança sobre estruturas de organização mais complexas, como a argumentação (que Aristóteles denominava o estudo das "provas" do discurso), um dos focos do interesse atual nos estudos contemporâneos. Para Koch, a argumen- 
tatividade é uma característica fundamental da interação por meio da língua, formando um princípio estruturante do discurso, o qual, portanto, dificilmente poderia ser "neutro". O ser humano, dotado de razão e vontade, estaria permanentemente avaliando e criticando, formando juízos sobre as coisas, enquanto, por outro lado, procuraria comunicar essas percepções, de maneira a influenciar os demais, buscando fazer com que compartilhem de suas opiniões.

O pensador belga Chaim Perelman defende a importância social da argumentação, trazendo sua análise para o campo da filosofia dos valores. Ele defende que não existe uma lógica específica para os julgamentos de valor, cujo fundamento deve ser buscado na Retórica. Para ele, quando se trata de

estabelecer o que é preferível, o que é aceitável e o que é razoável, os raciocínios não são nem deduções formalmente corretas, nem induções, indo do particular ao geral, mas argumentações de todo tipo, visando ganhar a adesão dos espíritos às teses que se apresentam a seu assentimento. (Perelman, 1977).

Perelman retoma, assim, a perspectiva de Aristóteles, que distinguiu duas espécies de raciocínios: os lógicos ${ }^{1}$ e os dialéticos. Aristóteles, criador da Lógica, tinha estudado as formas de inferências válidas, especialmente o silogismo. Ele considerava essa inferência puramente formal: como a verdade é uma propriedade das proposições, independente das opiniões dos homens, os raciocínios lógicos são demonstrativos e impessoais. Muito diferente é o caso dos raciocínios empregados no argumento retórico, que ele denominou dialéticos. Um raciocínio é dialético, diz Aristóteles, se as premissas são constituídas de opiniões geralmente aceitas, ou seja, opiniões aceitas por todos, pela maioria ou pelos filósofos, os mais notáveis e mais ilustres (Perelman, 1975). Os raciocínios dialéticos partem do que é aceito, mas seu objetivo é fazer admitir outras teses, que

$1 \mathrm{Na}$ terminologia aristotélica, raciocínios analíticos. Outros autores falam de raciocínios demonstrativos. 
são ou podem ser controversas: eles se propõem, pois, a convencer, persuadir.

Eles não consistem em inferências válidas e constritivas, mas apresentam argumentos mais ou menos fortes, mais ou menos convincentes e que não são nunca formais. Um argumento persuasivo é aquele que persuade aquele a quem se destina: contrariamente ao raciocínio analítico, o raciocínio dialético não é impessoal, porque ele se aprecia por sua ação sobre o espírito. Os raciocínios analíticos se apoiam na verdade, os outros na opinião. Cada domínio, exigindo um outro tipo de discurso, é tão ridículo contentar-se com argumentos razoáveis da parte de um matemático, quanto exigir provas científicas de um orador. (Perelman, 1977, p.17)

Para o autor, a lógica moderna identificou-se com os raciocínios analíticos e negligenciou os raciocínios dialéticos, próprios da $\mathrm{Re}$ tórica, considerados estranhos à lógica. Para ele, a teoria da argumentação seria uma nova retórica ou uma nova dialética, cobrindo todo o campo do discurso que visa a convencer ou a persuadir um público. A filosofia sempre opôs a busca da verdade às técnicas dos retores e sofistas, pois os filósofos sempre buscavam apoiar-se na universalidade da evidência. Mas, segundo Perelman, a dialética é indispensável justamente quando a evidência é contestada. Por isso, argumenta, o Organon de Aristóteles possui, ao lado dos Analíticos, voltados para o raciocínio lógico-formal, os Tópicos, que examinam os raciocínios dialéticos, aqueles que permitem justificar a melhor opinião, a opinião razoável.

Perelman acredita que o declínio da retórica, ao fim do século XVI, se deveu à ascensão do pensamento burguês, que generalizou o papel da evidência. Mas quando não há premissas universais, porém apenas opiniões divergentes, quando as escolhas razoáveis são precedidas de uma deliberação ou de discussões, quando diferentes alternativas são contrastadas, ressalta o valor da teoria da argumentação, que ele denomina a nova retórica. Em lugar de procurar uma verdade primeira, necessária e evidente, na qual se apoiaria todo 
nosso saber, Perelman defende que organizemos nossa filosofia em função de uma visão na qual são os homens e as sociedades humanas em interação os únicos responsáveis por suas culturas e suas instituições e seu futuro, que se esforçam para elaborar seus sistemas de raciocínio, imperfeitos, mas perfectíveis.

A ideia de que toda teoria científica não é mais que uma hipótese humana (...) não sendo nem evidente nem infalível é uma concepção moderna que Karl Popper defendeu com talento. (...) O estatuto do conhecimento deixa de ser impessoal porque todo pensamento científico se torna um pensamento humano, falível, situado e sujeito a controvérsia. (idem, p.175)

Perelman, dessa forma, apresenta o critério de validade dos raciocínios não-formais ou não-silogísticos: o acordo intersubjetivo, o consenso social que se quer estabelecer na política, na moral, no gosto, no Direito e mesmo na ciência, depois do debate sobre temas controvertidos. Esse acordo - e não propriamente as técnicas de persuasão - é que fornece a caução necessária à fixação de um valor. Assim, se a argumentação é essencial para obter a adesão a um valor, é o consenso em torno deste que, em última análise, o legitima.

Em trabalho no qual analisamos a retórica das campanhas políticas (Soares, 1996), propusemos a existência de dois modos retóricos básicos: o da persuasão e o da sedução. A estratégia da persuasão foi objeto principal da retórica aristotélica e constrói-se segundo a lógica do provável, da opinião, do verossímil, manifestando-se pela argumentação. A argumentação, por conseguinte, tem um conteúdo cognitivo, constituído de noções, princípios, valores. Mas, ao lado dela, observamos o emprego de uma estratégia da sedução, que mobiliza os sentimentos e os sentidos, buscando a atração da plateia por meio do encantamento. Seduzir, nesse caso, significa pôr em suspensão o razoável, em favor do prazer ou da emoção (o pathos, que também foi tratado por Aristóteles). A sedução, contemporaneamente, organiza-se pela comoção e pelo espetáculo, visando ao efeito estético e, por isso, seu modo de expressão por excelência é a dra- 
matização. O princípio desse modo retórico não é o argumento, mas a representação sensível, resultante da estruturação da mensagem como narrativa ou drama, pela sua encenação (caso da propaganda pela televisão). O objetivo não é convencer, mas contagiar, por apelo aos sentimentos e pela saturação dos sentidos, a fim de obter a adesão por uma identificação emocional com o discurso ou com a encenação, o ritual, liturgia, celebração ou festa. É, portanto, um modo retórico essencialmente irracionalista.

Na retórica contemporânea, pode-se observar a convivência dos dois modos retóricos, às vezes entremeados, como se observa, por exemplo, na propaganda eleitoral brasileira pela televisão.

\section{A visão retórica}

No contexto acadêmico norte-americano, também se deu, no século XX, um renascimento dos estudos retóricos, representado pela análise retórica (rhetorical criticism), abrindo novas e instigantes perspectivas teóricas. Uma das autoras dessa tradição, Sonja Foss (1989) entende que a retórica não diz respeito somente ao discurso falado e escrito, mas inclui símbolos não-verbais, os quais, ao lado da linguagem persuadem porque geram nosso conhecimento sobre o mundo. Não se trataria, portanto, apenas de uma tradução do conhecimento na forma persuasiva, mas do próprio processo pelo qual apareceria o conhecimento. A realidade ou o conhecimento do que venha a ser o mundo resultaria da comunicação sobre eles: a realidade não seria fixa, mas criada por meios retóricos. Como a retórica não é algo que apenas dá saliência à verdade, mas algo que participa de sua criação, a retórica é epistêmica (Foss, 1989).

Halliday (1992), autora brasileira da escola de análise retórica, estudando a publicidade de empresas, destacou o papel de definição de realidade, dizendo que as organizações empresariais, por meio de atos retóricos e atos administrativos, exercem uma ação simbólica legitimante, procurando redefinir sua atuação, no sentido de sua aceitabilidade social. Uma das formas de legitimação empregadas é 
a transcendência, obtida por meio da redefinição retórica da atividade principal da empresa, mostrando que ela vai além da produção do bem ou serviço; ou pela redefinição dos objetivos empresariais em termos de aspirações regionais, nacionais ou universais ou, finalmente, colocando os objetivos empresariais além dos limites do tempo, no futuro.

Hart (1990) diz que o orador faz a audiência esquecer outras ideias, pessoas e políticas para concentrar-se na sua mensagem. A retórica, então, estreita as escolhas da audiência sem dar a ela a sensação de estar sendo cerceada. A retórica engrandece coisas, fatos e pessoas utilizando associações ou dissociações com outras coisas, fatos e pessoas. Quando se refere ao passado, conta uma história seletiva, editada, na qual só figuram os fatos eleitos em função de sua funcionalidade para a ideia do discurso.

Lloid Bitzer (1968) propôs o conceito de situação retórica, dizendo que o discurso retórico aparece como resposta a exigências de uma dada situação problemática, as quais podem cessar por influência desse discurso, de modo que a importância de uma fala decorre da sua relação com uma determinada situação, como resposta a um problema. Para ele, em vez da persuasão, um discurso é retórico na medida em que funciona como uma resposta cabível a uma situação que o solicita. Por fim, a situação controla a resposta, sendo a verdadeira fonte da ação retórica.

O filósofo da retórica Kenneth Burke (1969) defende que a palavra-chave da retórica não é persuasão, mas identificação, por meio da qual a retórica promoveria a coesão social, induzindo a cooperação em seres que por sua natureza respondem a símbolos, sendo, por essa razão, fator da vida coletiva. A noção de identificação teve grande influência entre pesquisadores norte-americanos, como Ernest G. Bormann (1982, 1989), que procurou relacionar a retórica à organização da vida social, partindo da hipótese de que a realidade instaurada pelos símbolos é partilhada pelos grupos, por meio do que chamou de convergência simbólica. Sua teoria declara que os mundos simbólicos privados se inclinam um em direção ao outro, tornam-se mais próximos ou até mesmo se sobrepõem durante os processos de comunicação, trazendo o consenso sobre significados subjetivos. 
Bormann defende que essa convergência simbólica constitui uma base para a comunicação e para a criação da comunidade, na qual se podem discutir experiências comuns e alcançar a compreensão mútua. Para ele, pessoas que experimentaram conjuntamente emoções, que desenvolveram atitudes e interpretaram algum aspecto de sua experiência da mesma forma, em suma, que sentiram a convergência simbólica, partilham a mesma fantasia. Na terminologia do autor, fantasia não é uma ilusão imaginária, mas a "interpretação criativa e imaginativa de eventos" (Foss, 1989).

A teoria da convergência simbólica baseia-se nas experiências realizadas pelo próprio Bormann e por Robert Bales. Este descobriu o processo dinâmico de fantasia grupal, descrevendo a forma pela qual a comunicação dramatizada cria a realidade social para os grupos. Nas dramatizações, o drama é um espelho da situação do grupo: as ambiguidades, os choques de papéis, o conflito de liderança aparecem simbolizados no encadeamento da fantasia das pessoas. Valores e atitudes, dramas políticos e religiosos são testados e legitimados nesse processo, de maneira que os grupos acabam por criar uma cultura própria. Para Bales, a cultura do grupo traz aos membros o sentimento de ter entrado numa outra realidade, num mundo de heróis, vilões, santos e inimigos. A pessoa passa a viver num mundo de fantasia psicodramática, do qual os outros membros também fazem parte.

A hipótese de Bormann é de que essas vivências acontecem também em grupos maiores, como quando as pessoas ouvem um discurso público, bem como nos processos de comunicação de massa. As dramatizações que empolgam os pequenos grupos espalham-se por meio de públicos maiores, servindo para sustentar o senso de comunidade dos membros, para impeli-los à ação, fornecendo-lhes uma realidade social.

Bormann voltou-se então para a questão de saber até que ponto existe uma dimensão retórica da comunicação associada a esses episódios. Algumas fantasias de grupo se encadeariam mais facilmente, devido à habilidade com que o drama é representado. Assim, se um comunicador habilidoso, deliberadamente, pode agir retoricamente 
para influenciar uma audiência, fica demonstrada a existência de dramatizações planejadas, intencionais, em condições de captar a atenção de outras pessoas. Audiências massivas partilham fantasias, elaboradas cuidadosamente, com base em análises de públicos-alvo. A esses dramas compostos, que envolvem grandes grupos de pessoas, Bormann denominou visão retórica.

Seu método de análise objetiva delinear o "tema-fantasia" envolvido na comunicação, ou seja, o tema pelo qual o grupo realiza a interpretação de fatos do passado, de eventos atuais, da realidade dos participantes, em suma.

Bormann defende que as fantasias partilhadas são necessárias para a argumentação, no sentido de que são elas que estabelecem o sistema de pressupostos que constituem a base para os argumentos. Em outras palavras, a fantasia importa não apenas para os aspectos irracionais da persuasão, mas, também, fornece uma base para os argumentos racionais, uma vez que o argumento discursivo requer um conjunto de suposições sobre a natureza da realidade.

Pessoas que partilham de uma visão retórica formam uma comunidade retórica, participando de um sistema simbólico comum e respondendo às mensagens de maneira coerente à sua visão retórica. Os vilões e os heróis estarão definidos e provocarão sentimentos semelhantes, seu critério de evidência será o mesmo, bem como os motivos para sua ação, ou seja, o indivíduo participará do mesmo drama partilhado. O exemplo de Bormann é o do cristão que, ao ser batizado, nasce de novo, adota um estilo de vida e uma conduta determinada e modelada pelos heróis daquela visão retórica. Ele escreve:

Os indivíduos em transações retóricas criam mundos subjetivos de expectativas e significados comuns. Contra o panorama de grandes eventos e forças aparentemente imutáveis, da sociedade ou da natureza, o indivíduo frequentemente se sente perdido e desesperado. Um mecanismo para superar essa situação é sonhar uma fantasia individual que forneça um senso de significado e sentido para o indivíduo e ajude a protegê-lo das pressões da calamidade natural e do desastre social. A visão retórica serve muito bem a essa função de 
luta para aqueles que participam no drama e frequentemente com muito mais força devido ao calor do apoio dos companheiros com mentalidades semelhantes. (Bormann, 1989, p.214)

Para Bormann, as palavras não emanam simplesmente do contexto social, elas são o contexto social. Nos momentos confusos, ambíguos, as pessoas são liberadas para fantasiar, segundo sua visão retórica, quando, então, os temas-fantasia se convertem nos principais sistemas explicativos para os fatos, como o ilustram os boatos. Como é a visão retórica que proporciona o sentido das ações, estas têm pouco sentido para as pessoas de fora, mas podem ser imperativas no contexto da visão, que lhes proporciona o motivo, legitima-as e as explica. Para Bormann, o drama de tema-fantasia de uma grande coletividade é uma chave para a compreensão da realidade social, na medida em que a participação nele proporciona aos indivíduos as emoções, significados, atitudes com relação às personae do drama, permitindolhes compartilhar uma visão comum de um aspecto da experiência. ${ }^{2}$

\section{A luta pelo sentido}

Por um lado, as pesquisas de Bormann sugerem uma intersecção da retórica com a ideologia. Por outro, para um teórico da ideologia

2 Há uma semelhança entre o conceito de tema-fantasia, proposto por Bormann, e o de imaginário social, de Bakzco (1984). No Brasil, José Murilo de Carvalho tratou do tema em A conquista das almas, sobre o imaginário republicano, texto no qual afirma: "A elaboração de um imaginário é parte integrante da legitimação de qualquer regime político. É por meio do imaginário que se podem atingir não só a cabeça mas, de modo especial, o coração, isto é, as aspirações, os medos e as esperanças de um povo. É nele que as sociedades definem suas identidades e objetivos, definem seus inimigos, organizam seu passado, presente e futuro. O imaginário social é constituído e se expressa por ideologias e utopias, sem dúvida, mas também - e é o que aqui me interessa - por símbolos, alegorias, rituais, mitos. Símbolos e mitos podem, por seu caráter difuso, por sua leitura menos codificada, tornar-se elementos poderosos de projeção de interesses, aspirações e medos coletivos" (1990, p.10). 
como Ansart (1978), ela deve ser vista como a expressão simbólica de conflitos em curso na sociedade, o que a insere, desde logo, no campo da linguagem. A noção de ideologia passa a englobar o conjunto de linguagens políticas de uma sociedade, por meio das quais os conflitos sociais se formulam no campo das posições simbólicas e, com isso, chama a atenção para o estudo da linguagem dos movimentos políticos, constituída na ação dos grupos, em resposta a antagonismos, linguagem condicionada por circunstâncias que cabe analisar em cada caso.

Marx pôs em evidência as ideologias como expressões dos interesses das classes e toma os conflitos ideológicos como resultante das contradições sociais. Em Marx, as ideologias são a linguagem da existência social, diz Ansart, ou seja, o sistema de representações não é uma ilusão ou epifenômeno, mas participa das atividades como parte constituinte e as define como prática. Porém, as ideologias aparecem não como simples repetição de uma situação social dada, constituindo, antes, um instrumento eficaz no processo de luta política, dotado de uma especificidade que pode ser estudada em cada caso.

Assim, conclui Ansart, há uma correspondência entre as oposições simbólicas e aquelas que se dão na prática social. O campo ideológico é inerentemente concorrencial e conflitivo, a violência simbólica caracteriza o campo ideológico, no qual cada locutor procura afirmar-se em relação aos demais, pela conquista e conservação de um status ideológico, o que suscita uma posição agressiva e defensiva. Essa confrontação, no entanto, se dá em termos puramente simbólicos, como substituta de uma violência efetiva. A luta ideológica reelabora e deforma discursivamente os conflitos sociais e políticos, estabelecendo um esquema perceptivo e explicativo, por meio do qual militantes se definirão e se situarão em relação aos adversários.

Ao contrário da linguagem científica, cuja característica é o distanciamento, a linguagem ideológica designa-se explicitamente. Além disso, a linguagem ideológica é normativa, exprime um dever ser, a linha justa, conclamando à adesão, à ação. Ela ultrapassa a distância entre conhecimento e moral, dando ao grupo os meios de ação e de reconciliação consigo mesmo. Por isso, é comum que 
a ideologia sirva para orientar as oposições, aumentando o conflito para obter a integração.

As simplificações, os amálgamas analógicos que constituem a ideologia dão aos indivíduos a segurança para vencer as dúvidas, permitem a ele projetar sobre a diversidade do real a unidade tranquilizadora do sentido, proporcionando um sentimento satisfatório de dominar simbolicamente a realidade. O indivíduo encontra na ideologia um esquema facilmente comunicável, unificado, que o convida a definir-se e a reconhecer-se na imagem gratificante que lhe é proposta. Por outro lado, a ideologia é uma linguagem para os membros do grupo, permitindo-lhes uma sociabilidade, designando os pontos em comum, definindo aquilo em que há acordo, gerando a comunicação entre as pessoas, congregando-as como indivíduos portadores de uma causa justa.

A beleza da linguagem estrutura as emoções coletivas, conseguindo criar o consenso pelo controle dos fluxos afetivos. $\mathrm{O}$ ajuste das motivações, o acordo sobre os significados, o entendimento, a confirmação pelo outro de minha boa imagem, a exaltação coletiva, a participação fusional (grito, o canto coletivo) dão à linguagem política uma função de terapia social, na medida em que ela diminui as tensões e as potencialidades de destruição no seio do grupo.

Nos regimes pluralistas, segundo Ansart, a crítica das ações governamentais é uma atividade permanente, institucionalizada. Com isso, cria-se a impressão de que todas as posições são provisórias e contestáveis, pois há uma tendência à multiplicação indefinida das interpretações, uma pluralidade de "razões", situação oposta àquela dos regimes autoritários, em que o sucesso está ligado à demonstração de fidelidade à ortodoxia. Devido à confrontação verbal cotidiana, o partido, num regime pluralista, precisa, ao mesmo tempo em que proclama sua permanência, adaptar suas tomadas de posição às circunstâncias, inventando novos modos de conciliação entre as linguagens antigas e as novas exigências. O pluralismo é a condição da expressão dos interesses divergentes e da sua confrontação pacífica, bem como a manifestação das divergências sociais. Ao contrário dos regimes ortodoxos, que proclamam a identidade de interesses, 
o pluralismo transforma a vida política em história de conflitos, tornando-os regra comum em todos os níveis da vida. O dissenso é considerado normal, a sociedade adquire uma agressividade que se expressa sob a forma de violência simbólica. O pluralismo provoca a proliferação e diversificação dos significantes políticos. Os líderes precisam manter o prestígio por meio de uma produção regular de signos legitimadores. Trata-se de uma atividade que conhece um ritmo sazonal, acalmando-se entre as eleições, para intensificar-se na sua proximidade.

\section{Retórica, ideologia e pensamento}

A retórica constitui uma totalidade forma-conteúdo, capaz de, em situações sociais contraditórias, representar as questões a partir de certo prisma, atribuindo-lhes determinado significado e sentido, direcionando o julgamento e raciocínio da audiência, de modo a influir nas atitudes e ações a respeito.

Já a ideologia é um pensamento a serviço da legitimação de um poder, dissimulando essa função sob uma aparente racionalidade (Reboul, 1980). Enquanto discurso, seu conteúdo é inseparável de sua forma, de seus termos, pelos quais se expressa. Assim, tomando a ideologia como uma organização discursiva, podemos afirmar que sua forma de expressão é a retórica. Como consequência de sua estrutura retórica, a ideologia visa dirigir a interpretação dos acontecimentos, ela "pensa por nós", é um "prêt à penser", na expressão de Reboul.

Na qualidade de retórica, que opera de forma "quase lógica" ou "aparentemente lógica", a ideologia consegue responder às questões incertas, às controvérsias que as ciências - em especial as Ciências Sociais - não resolveram, dando um determinado significado às informações, um projeto para uma coletividade, um sentido à sua prática (Ellul, 1962). Mas as ideologias não são nunca plenamente verificáveis do ponto de vista das evidências científicas e seu núcleo esconde sempre uma tomada de posição de ordem afetiva, expres- 
sando especialmente sentimentos negativos, como o ódio, o medo, o ressentimento (Reboul, 1990).

Buscando integrar aspectos convergentes de ambos os conceitos, diríamos que a ideologia pode ser entendida como a) o discurso retoricamente formulado, b) expressando uma opinião, geralmente coletiva, c) que se desenvolve numa situação de incertezas ou de indeterminação política e social, d) num clima fortemente emocional, e) num contexto de antagonismo social e político, f) servindo para renovar as paixões coletivas e aumentar a coesão social em torno de uma liderança ou de um poder.

As ideologias afirmam-se e disseminam-se com relativa facilidade porque, não sendo proposições científicas, estão, geralmente, imunes à crítica epistemológica (e até mesmo a uma crítica lógica), podendo ser dominadas, eventualmente, pelos falsos silogismos ou falácias, pela sedução das frases espirituosas, pelas emoções imediatas. Assim, elas podem, com maior destreza, encaminhar sutilmente o curso dos pensamentos e avaliações, traindo insensivelmente a coerência e consistência dos argumentos.

As ideologias não são exclusividade de algumas orientações políticas específicas, de esquerda ou de direita, podendo infiltrar-se em diversas falas, mesmo as de cunho científico, aparecendo como formulações politicamente enviesadas. Isso não significa, no entanto, que não possa haver proposições verificáveis empiricamente nas ideologias, as quais, aliás, fornecem-lhes uma espécie de caução relativa, já que uma ideologia sem qualquer ligação com a experiência, verossimilhança e sem o apoio no conhecimento científico, especialmente hoje, não teria chance de ser aceita. Esse suporte de evidências pontuais, no entanto, não garante que o edifício ideológico, especialmente nas conclusões, apresente coesão e adequação à realidade.

A retórica na época contemporânea comparece como argumentação ou sedução, na instauração de imaginários (ideologias ou mitologias), constituindo o discurso publicitário, a propaganda política e o discurso religioso, ou seja, em todas as situações em que se procura estabelecer um consenso social parcial ou geral, em apoio a determinadas teses com sentido político. O poder do discurso linguístico, 
hoje, é intensificado ao integrar-se com as imagens, formando as linguagens sintéticas do cinema, da televisão e da internet, mas a propriedade de formular conceitos, avaliações e interpretações continua exclusividade da língua, por meio qual se formulam conceitos, julgamentos e avaliações (Barthes, 1975).

Finalmente, as ideologias existem não apenas porque há interesses divergentes enraizados na sociedade, especialmente nas classes sociais, mas também porque não há certezas absolutas nem critérios racionais definitivos para avaliação de uma quantidade de fatos, decisões políticas e suas consequências futuras. Mais do que isso, do ponto de vista lógico, muitas proposições submetidas à avaliação pela sociedade encerram antinomias que as tornam dilemas indecidíveis, de modo que para seu julgamento, frequentemente, dispomos apenas das preferências, das opiniões e dos valores (éticos, políticos, estéticos). E esses elementos, como já vimos, é que desenham o campo próprio da retórica.

\section{Referências bibliográficas}

ANDREWS, J. R. The practice of rhetorical criticism. Nova Iorque: Mac Millan, 1983.

ANSART, P. Ideologias, conflitos e poder. Rio de Janeiro: J. Zahar, 1978. ARISTÓTELES. Arte retórica e arte poética. Rio de Janeiro: Ediouro, s/d. Tópicos. Dos argumentos sofísticos. São Paulo: Nova Cultural, 1991.

BACZKO, B. Les imaginaires sociaux: mémoires et espoirs collectifs. Paris: Payot, 1984.

BARTHES, R. Elementos de semiologia. São Paulo: Cultrix, 1975. Mitologias. São Paulo: Difel, 1980.

BITZER, L. The rhetorical situation.Philosophy and rhetoric, v.1, n.1, p 1-14, Winter, 1968.

Functional communication, a situational perspective. In: WHITE, E. (Ed.). Rhetoric in transition: studies in the nature and uses of rhetoric.

University Park: Pennsylvania State University, 1980. p.21-38.

BORMANN, E. G. Fantasy and rhetorical vision: ten years later. Quarterly Journal of Speech, n.68, p.288-305, 1982. 
Fantasy and rhetorical vision: the rhetorical criticism of social reality. In: BROCK, B., SCOTT, R. L., CHESEBRO, J. W. (Orgs.) Methods in rhetorical criticism. Detroit: Wayne State University. p.210-21.

BOYER, H. Le langage en spéctacle. Paris: L'Harmattan, 1991.

BRINTON, A. Situation in the theory of rhetoric. Philosophy and rhetoric, v.14, n.4, p.234-48, fall 1981.

BURKE, K. A rhetoric of motives. Berkeley and Los Angeles: University of California Press, 1969.

BURKE, P. A fabricação do rei. Rio de Janeiro: J. Zahar, 1994.

CARVALHO, J. M. de. A formação das almas: o imaginário da República no Brasil. São Paulo: Companhia das Letras, 1990.

CATHCART, R. S. Post-communication rhetorical analysis and evaluation. Indianapolis: Bobbs-Merril, 1981.

CORCORAN, P. E. Political language and rhetoric. Austin: The University of Texas Press, 1979.

COUTINHO, O. M. Fernando Collor: o discurso messiânico - o clamor do sagrado. São Paulo, 1995. 146p. Dissertação (Mestrado em Comunicação e Semiótica) - Pontifícia Universidade Católica de São Paulo, 1995.

DUNCAN, H. D. Symbols in society. Nova Iorque: Oxford University Press, 1968.

EDELMAN, J. M. The symbolic uses of politics. Urbana: University of Illinois Press, 1964.

ELLUL, J. Propagandes. Paris: Armand Colin, 1962.

ENRIQUEZ, E. Da horda ao Estado. Rio de Janeiro: J. Zahar, 1990.

FIORIN, J. L. O regime de 1964 - discurso e ideologia. São Paulo: Atual, 1988.

FOSS, S. K. Rhetorical criticism, exploration and practice. Prospect Heights: Waveland Press, 1989.

GIRARDET, R. Mitos e mitologias políticas. São Paulo: Companhia das Letras, 1987.

GRANAI, G. Problemas de sociologia da linguagem. In: GURVICH, G. (dir.) Tratado de Sociologia. S. Paulo: Martins Fontes, s. d. v.2, p.353-83.

HALLIDAY, T. L. A retórica das multinacionais: a legitimação das organizações pela palavra. São Paulo: Summus, 1987.

(org.) Atos retóricos: mensagens estratégicas de políticos e igrejas.

São Paulo: Summus, 1988.

O que é retórica. São Paulo: Brasiliense, 1990.

Definições da realidade ambiental: a "causa ecológica" na legitimação das organizações. (Apresentado no GT de Comunicação Organizacional 
do XV Congresso Brasileiro de Ciências da Comunicação. São Bernardo do Campo, 1992). Recife, Universidade Rural de Pernambuco, 1992. 23 p. (Mimeogr.)

HART, R. P. $\backslash$ Modern rhetorical criticism. Glenview-Londres: Scott, Foresman/Little, Brown, 1990.

HUNSAKER, D., SMITH, C. R. The nature of issues: a constructive approach to situational rhetoric. Western Speech Communication, p.144-56, Summer, 1976.

KOCH, I. G. V. Aspectos da argumentação em língua portuguesa. São Paulo, 1981. Tese (Doutoramento em Ciências Humanas: Língua Portuguesa) - Pontifícia Universidade Católica. Argumentação e linguagem. São Paulo: Cortez, 1993.

MAINGUENEAU, D. Iniciation aux méthodes de l'analyse du discours. Paris: problèmes et perspectives. Paris: Hachette, 1976. . Novas tendências em análise do discurso. Campinas: Pontes, 1989. OSAKABE, H. Argumentação e discurso político. São Paulo: Kairós, 1979. PERELMAN, Ch. L'empire rhétorique: rhétorique et argumentation.Paris: Librairie Philosophique J. Vrin, 1977.

REBOUL, O. Langage et idéologie. Paris: Presses Universitaires de France, 1980.

SILVEIRA, R. A., PERGHER, G. K., GRASSI-OLIVEIRA, R. Linguagem e pensamento: visão (supra) comunicativa acerca da linguagem. Ciências E Cognição, ano 2, v.6, nov 2005. Disponível em www. cienciasecognição.org.

SOARES, M. C. Construindo o significado do voto: retórica da propaganda política pela televisão. Tese de doutoramento. São Paulo, 1996. USP. TRINGALI, D. Introdução à retórica. São Paulo: Duas Cidades, 1989. 


\section{3 \\ FORMAS DA REPRESENTAÇÃO JORNALÍSTICA}

O papel dos meios é estabelecer os limites dentro dos quais vão disputar todas as definições de realidade em competição.

Todd Gitlin

O surgimento da imprensa diária, no século XIX, instaurou a primeira forma contemporânea de informação, expressão e debates, instaurando o espaço público ampliado, sendo seguida, a partir do século XX, pela radiodifusão. Essas tecnologias levaram a análises relacionadas à participação dos meios no processo político, as quais aparecem em trabalhos contemporâneos, especialmente nos que tratam das teorias sociológicas do jornalismo.

O enfraquecimento histórico das oposições doutrinárias, acelerado a partir da década de 1990, em virtude do fim dos regimes socialistas na Europa, fez com que o conceito de ideologia tenha deixado o proscênio das pesquisas acadêmicas. Embora ele possa ser ainda apropriado para análises de questões e de doutrinas políticas em perspectiva histórica, em contextos de oposição filosófica explícita, do ponto de vista metodológico, nas análises mais circunscritas, é preferível estabelecer conceitos mais operacionalizáveis, que permitam estreitar o foco em fenômenos mais restritos, como conteú- 
dos dos meios de comunicação, objetos sobre quais nem sempre é viável desenvolver análises ideológicas stricto sensu. Numa época de atenuação ideológica, as representações da realidade social se disseminam de forma sutil nas reportagens, como vestígios de matrizes doutrinárias. Essas formas discursivas são, no entanto, capazes de indicar inclinações num contexto de sentidos em oposição. No caso de investigações sobre gêneros bem determinados, como o jornalismo, além do mais, é preferível desenvolver conceitos próprios, a fim de conferir uma identidade aos fenômenos em estudo, distinguindoos nitidamente de investigações políticas e filosóficas. Os conceitos de agendamento e enquadramento têm se destacado no exame das formas de representações jornalísticas que constroem das percepções do mundo social, sendo frequente a busca de seus vínculos com a política, em contextos democráticos. Vamos examinar cada um deles, fazendo, em seguida algumas reflexões sobre sua influência real nos processos sociais e políticos.

\section{Agendamento e representação política}

No domingo, 19 de março de 2006, o programa de televisão Fantástico, da Rede Globo de Televisão, fugindo ao seu formato padronizado de décadas, de revista de variedades, exibiu em quatro blocos o documentário Falcão: meninos do tráfico, com uma hora de duração, dirigido pelo músico M. V. Bill, gravado em comunidades pobres, mostrando como o tráfico usa e destrói crianças num processo implacável. No documentário, são as próprias crianças e adolescentes envolvidos que narram suas histórias limitadas, demonstrando consciência do risco que, em pouco tempo, levaria a maioria dos jovens entrevistados à morte. Uma sequência mostra crianças brincando de traficar drogas, de lutar contra grupos rivais e da executar um alcaguete.

As cenas chocantes do documentário provocaram, no dia seguinte, manifestações de políticos pelos meios, principalmente os das Organizações Globo, mas também apareceram pronunciamentos ao vivo de senadores pela TV Senado, comentando a gravidade do que 
fora mostrado e defendendo a necessidade de ações para modificar a situação. A condição dos meninos do tráfico já era difundida, principalmente após o sucesso do filme Cidade de Deus, mas talvez estivesse "latente" na voragem dos noticiários. Quando a questão foi colocada em destaque em um programa de elevada audiência nacional, vozes da sociedade priorizaram instantaneamente o tema e as autoridades sentiram que precisavam manifestar uma posição indignada como resposta à opinião pública, nem que fosse verbalmente.

O que se pode verificar nesse episódio é que a Rede Globo estava conseguindo pautar a agenda política, destacando um tema social, que não costuma frequentar com tal intensidade e duração a programação da TV, especialmente nesse programa, uma revista semanal de grande audiência em todo o país. O caso ilustra o poder de agendamento das preocupações do público pelos meios.

Devido ao seu poder de definição da agenda pública, Miguel (2003) identifica os meios de comunicação como forma de representação política. Já no debate político das campanhas eleitorais é possível perceber a importância da agenda pública para o eleitor, pois as alternativas eleitorais são situadas num campo de controvérsias sobre determinados temas pautados pelo jornalismo: a informação relevante para a decisão do voto encontra-se num quadro restrito que é a agenda mediática. A mesma situação ocorre quando os eleitores julgam a conduta pretérita de seus representantes, decisão que está balizada pela agenda pública. Como os meios são disseminadores mais importantes de conteúdos simbólicos, diz o autor, a pauta das questões consideradas relevantes acaba sendo influenciada pela visibilidade mediática dessas questões, de modo que até mesmo os políticos precisam sensibilizar os meios antes de proporem certos assuntos na agenda pública. Ele conclui que "a relação entre representantes e representados depende, em grande medida, dos assuntos tematizados e colocados para decisão". Agendamento constitui, portanto, uma faculdade ou atributo da representação jornalística, implicando o poder de estabelecimento de uma hierarquia coletiva de importância, prioridades para a sociedade (e estabelecer prioridades é a própria definição da política). 
Fuks (2002) também identifica a formação de agenda como uma questão politicamente importante, que desloca o foco dos estudos dos assuntos públicos das suas condições objetivas para o estudo dos processos sociais relacionados às disputas pela sua definição, em arenas argumentativas. Igualmente, reconhece que a comunicação de massa, na medida em que atua como ponte de articulação entre as demais arenas e como canal de difusão do que ocorre dentro delas, é uma arena estratégica para a formação da agenda pública.

Maxwell McCombs, um dos proponentes do conceito e pesquisador pioneiro do agendamento, ou agenda setting, diz que a agenda pública é uma realidade de segunda mão, estruturada pelas reportagens de jornalistas. A maneira de conhecer qual a agenda do público é perguntando a uma amostra da população "qual é o mais importante problema do país hoje?" Quando se tabulam os resultados, percebe-se que alguns assuntos indicados como os mais importantes pelo público são aqueles enfatizados nas reportagens, de modo que se pode estabelecer uma correspondência entre os destaques dos meios noticiosos e a agenda das preocupações sociais. Essa não seria uma influência premeditada, mas um resultado da necessidade dos meios de selecionarem e destacarem uns poucos tópicos em seus noticiários. ${ }^{1}$

As pesquisas realizadas em diversos países mostram que, em geral, a agenda do público é limitada, não tendo lugar para mais do que de cinco a sete assuntos, de modo que há uma competição entre os assuntos por uma colocação na lista das prioridades coletivas. Por outro lado, não mais do que cinco assuntos correspondem a dez por cento ou mais das respostas do público e poucos assuntos têm estado por longo tempo no centro das atenções da opinião pública

1 A partir de referências teóricas distintas, o pesquisador Venício Artur de Lima (1994, 1995, 2001) propôs o conceito de Cenário de Representação da Política (CR-P) que, a nosso ver, implica a questão do agendamento. O CR-pé o cenário formado pelas representações hegemônicas da política que aparecem na rede de televisão dominante e que, por força de sua difusão, acaba constuituindo o âmbito do pensamento e das decisões da maioria dos cidadãos, em especial no processo eleitoral. 
norte-americana. O nível educacional faz com que haja um alargamento dos assuntos, mas não um aprofundamento, diz McCombs (2004), afirmando que as pesquisas mostram que mesmo pessoas altamente educadas raramente conhecem em detalhe e profundidade as questões públicas.

McCombs explica o agendamento como um resultado da necessidade de orientação das pessoas na sociedade contemporânea, que pode ser definida em termos de duas variáveis: relevância e incerteza. Relevância significa o sentimento de que um determinado assunto tem alguma importância pessoal ou importância para o conjunto da sociedade. O nível de incerteza exprime o desconhecimento de aspectos relacionados a um tópico e acontece em situações não-familiares, quando os leitores deparam com situações novas. A necessidade de orientação será baixa quando tanto a relevância quando o nível de incerteza forem baixos. Quando a relevância é alta e a incerteza é baixa, a necessidade de orientação será moderada. Por fim, quando se combinam a alta relevância do assunto e um alto grau de incerteza, tem-se uma alta necessidade de orientação. É justamente nessas situações de maior necessidade de orientação que se encontram os valores mais altos de correlação entre as agendas de leitores e dos jornais, ou seja, quando ocorre com mais intensidade o processo de agendamento (McCombs, 2004).

\section{Papel da noticiabilidade no agendamento}

Para McCombs, a teoria de agendamento convencional, relativa aos leitores, constitui apenas uma aplicação limitada da teoria, pois agendamento na realidade diz respeito a qualquer processo de transferência de saliência de uma agenda a outra. Após o reconhecimento do fenômeno do agendamento, a pergunta que os pesquisadores passaram a fazer passou a ser: "e quem agenda os meios?" McCombs responde que há três níveis de influência: primeiro, as fontes externas de notícias como o governo, porta-vozes, campanhas políticas; segundo, o agendamento recíproco entre os meios de comunicação; 
terceiro, as normas sociais e tradições do jornalismo. Tratando do primeiro nível, ele observa um movimento circular no relacionamento entre a cobertura de notícias e a evolução das políticas públicas, num padrão documentado, nos Estados Unidos, para assuntos como AIDS, aquecimento global e drogas. Muito do que sabemos tem origem em informação oficial; as autoridades públicas constituem uma importante fonte de notícias. As campanhas eleitorais também fazem um esforço para capturar a agenda dos meios. Já o agendamento intermeios significa que os meios de elite exercem influência sobre a agenda dos outros meios e que os jornalistas observam as coberturas de seus colegas, como forma de validar seus próprios julgamentos sobre os acontecimentos, o que explicaria a redundância da agenda de notícias. Por fim, as normas do jornalismo exercem uma pressão em direção à homogeneidade das notícias diárias.

A discussão dos critérios jornalísticos leva, implicitamente, à questão da noticiabilidade, que vem sendo objeto de diversos estudos (Wolf, 1986; Souza, 1995; Traquina, 2005). As teorias contemporâneas têm mostrado um progressivo afastamento das concepções mais convencionais, que concebiam a notícia como reflexo da realidade, a denominada "teoria do espelho", inclinando-se em direção a perspectivas construcionistas e estruturalistas e interacionistas, que veem o concurso de diversos fatores na construção do noticiário dos meios (Traquina, 2004).

Os jornais ocupam-se prioritariamente do que é inédito, traduzindo certo nível de incerteza, como ocorrências imprevistas e acontecimentos fortuitos que apresentam interesse maior para serem convertidos em notícias. Relatos sobre questões permanentes, situações estáveis, ou processos com alguma permanência, supostamente sabidos, "óbvios" no sentido da sua previsibilidade, formando um "estado de coisas", têm baixo grau de informação, não constituem notícia, no sentido de novidade, e só são abordados a propósito de uma notícia, que fornece o que os jornalistas denominam "gancho jornalístico”, ou seja, um pretexto ou motivo para referir-se a elas.

Por exemplo, um acidente (incêndio, deslizamento) ocorrido em uma favela pode motivar uma reportagem sobre a precariedade desse 
assentamento humano e sobre as condições de vida dos seus moradores, embora seja um tipo de habitat urbano secular, motivando interesse secundário dos jornais em situações de normalidade. $\mathrm{Ou}$ seja, acontecimentos com certo ineditismo ou incerteza (eleições, revoluções, acidentes) por serem menos prováveis têm maior taxa de informação (Pignatari, 2003), suscitando mais atenção dos meios noticiosos. Isso faz com que o noticiário seja definido por alguns critérios próprios dos meios noticiosos, destacando principalmente a novidade. Mas, observam os pesquisadores, além do ineditismo, é preciso que esse acontecimento ocorra dentro de certo espectro da realidade, caracterizado como mais noticiável segundo os critérios do meio, mas geralmente envolvendo governo, crime, economia, pessoas importantes - quer dizer, há critérios profissionais, mas que são também culturais e sociológicos para determinar o que vem a ser a notícia, qual será o destaque das manchetes etc. A conclusão que julgamos reiterar neste ponto é que a agenda dos meios é uma função, também, da noticiabilidade ou, em outras palavras, os temas com maior potencial de formarem a agenda dos jornais são os que apresentarem maior noticiabilidade, segundo os critérios profissionais jornalísticos. ${ }^{2}$

No caso da política, os acontecimentos institucionais, as ações de personalidades políticas, a inadequação à ética política e à legalidade são altamente noticiáveis pelos meios. Eventualmente, estes podem tomar a iniciativa de investigar, pesquisar, criticar, denunciar, agindo no sentido de "criar" um item de agenda, em vez de colocar-se atrás dos acontecimentos. Essa possibilidade coloca em consideração, portanto, o viés possível da visão própria ou do interesse do grupo editorial, além do jogo livre das forças de atuação profissional.

A relação da agenda com os fatores da noticiabilidade em geral, na perspectiva que estamos tratando, aparece representada nas figu-

2 Pode-se contradizer essa conclusão, aduzindo a interferência na agenda mediática de interesses políticos ou econômicos dos grupos proprietários dos meios. Essa discussão, que tem relevância indiscutível, no entanto, nos levaria para longe de nosso propósito neste capítulo e será discutida em outra parte do volume. 
ras 1 e 2. Em ambos os casos, trata-se da transferência de saliência entre agendas, passando pelo filtro da noticiabilidade, que, como vimos, é, frequentemente, arbitrado pelos critérios jornalísticos ou pelos meios noticiosos. A figura 1 inspira-se no roteiro descrito por McCombs, que toma o governo como o primeiro agendador, conseguindo pautar os meios. Na figura 2, temos como ponto de partida um evento, avaliado positivamente pelos critérios de noticiabilidade, sendo transferido para a agenda dos leitores e, eventualmente, se for cabível (notícias sobre segurança, legalidade, serviço público etc.), para a agenda do governo (autoridades dos poderes executivo ou judiciário, parlamentares).

\section{AGENDA DO GOVERNO + (NOTICIABILIDADE?) $\rightarrow$ AGENDA $\rightarrow$ AGENDA DOS MEIOS DOS LEITORES}

Figura 1: Percurso provável do agendamento a partir do governo

No caso da figura 1, é importante destacar que as ações e falas dos órgãos do governo e das autoridades têm um peso muito importante na definição das pautas das redações, não só por critérios estritos de noticiabilidade (prestígio, poder e importância das fontes governamentais), mas, também, em razão de essas instâncias estarem incluídas nas rotinas diárias dos jornalistas, com finalidade de garantir a produção adequada de notícias nos ciclos diários de reportagem e edição das matérias até os horários de fechamento. Essa circunstância garante ao governo uma proeminência indiscutível na agenda mediática, em relação a outras fontes (movimentos sociais, cientistas, críticos da política) que não estejam incluídas nas rondas jornalísticas diárias.

EVENTO + (NOTICIABILIDADE) AGENDA AGENDA AGENDA (ou fonte) $\rightarrow$ DOS è DOS $\rightarrow$ DOS MEIOS LEITORES GOVERNO

Figura 2: Percurso provável do agendamento, a partir de eventos 
Na figura 2, pode-se ver um percurso provável originário de uma fonte não governamental ou de um evento, sendo necessário observar que nem todo assunto agendado pelos meios tornar-se-á objeto de política pública ou mesmo de ações específicas. Muitas vezes, ao assunto pautado pelos meios o governo responde apenas retoricamente, por meio de notas oficiais, discursos, justificativas protocolares etc. Por exemplo, as altas taxas de juros no governo Lula, ao longo dos anos de 2005 a 2007, foram muito criticadas pelos meios, expressando a opinião da maioria dos empresários e dos economistas ligados às universidades e aos setores produtivos da economia, que viam nessa política um entrave ao crescimento econômico. No entanto, essa crítica sistemática atravessou o ano sem afetar a política do Comitê de Política Monetária do Banco Central, que nas suas reuniões mensais deliberou manter as taxas em patamar elevado, a pretexto de ameaça de um retorno da inflação. O mesmo se pode dizer das críticas à complexidade fiscal no Brasil, que vêm sendo veiculadas pelos meios há anos e que, apesar disso, não deflagraram uma reforma tributária ou diminuição do excesso de legislações da matéria. Outros exemplos poderiam ser arrolados nessa mesma direção.

Outras vezes, no entanto, a imprensa claramente influiu nas decisões parlamentares, como foi o caso das críticas reiteradas dos meios no final do ano de 2005 aos salários extraordinários dos deputados em convocações em períodos de férias, bem como à excessiva duração do recesso parlamentar, que levaram imediatamente à votação da legislação, durante a convocação extraordinária de janeiro de 2006, reduzindo a duração do recesso parlamentar do Congresso e a proibindo pagamentos extras aos deputados e senadores em convocações extraordinárias. Outras vezes, o agendamento expressa-se em medidas do Executivo, como o anúncio de construção de presídios, em face do noticiário sobre condições subumanas dos presos ou notícias de rebeliões. Ou seja, a afirmação de Miguel (2003) sobre o poder dos meios de agendar as políticas públicas precisa ser relativizada, mesmo porque as evidências obtidas sobre o processo de agendamento dizem respeito à agenda dos leitores, não do governo. 
Assim, às vezes, pode-se perceber a influência dos meios na ação do governo, outras vezes, ela não é visível. Há muitas leis sendo votadas e iniciativas da esfera administrativa que têm motivações em outros âmbitos (técnicos, setoriais, administrativos) e não foram pautadas pelos meios, ou seja, o governo tem suas agendas pautadas internamente, ou por outros atores como setores da sociedade. Por essas trajetórias alternativas pode-se perceber como é complexa a avaliação do papel político dos meios na definição das prioridades das ações governamentais.

\section{Enquadramento}

Enquadramento (framing) é um conceito surgido na Sociologia e trazido para os estudos de comunicação, sendo empregado para referir-se às propriedades construtivas das representações jornalísticas. As referências originais desse conceito vêm da obra Frame analysis, do sociólogo norte-americano Erving Goffman (1974), na qual os enquadramentos são definidos como marcos interpretativos construídos socialmente, que permitem às pessoas atribuírem sentido aos acontecimentos e às situações sociais, basicamente, respondendo à pergunta: "o que está acontecendo aqui"? Ou seja, trata-se de um processo de definição de situação, implicando construção de sentido para os eventos cotidianos. A psicologia cognitiva é outra fonte importante do enquadramento, por meio de pesquisas que demonstram como mudanças na formulação de problemas provocam variações nas percepções das pessoas (Porto, 2004).

Trazido aos estudos de jornalismo, o enquadramento diz respeito à capacidade dos meios de produzirem e disseminarem implicitamente uma interpretação do mundo, por intermédio de uma retórica implícita, entranhada na própria estrutura das matérias jornalísticas, indicando o papel dos meios noticiosos na construção das representações públicas. Os enquadramentos de notícias existiriam em dois níveis: a) como princípios mentais ou esquemas de processamento da informação e b) como características do texto noticioso (Entman, 
1991). Nesse caso, os enquadramentos residem nas propriedades específicas da narrativa noticiosa que encorajam percepções e pensamentos sobre eventos e compreensões particulares sobre eles. Os enquadramentos de notícias são construídos por palavras, metáforas, conceitos, símbolos e imagens visuais enfatizadas na narrativa noticiosa.

Porto (op. cit.) lembra que o conceito foi utilizado pela primeira vez nos estudos de comunicação pela socióloga Gaye Tuchman, no livro Making news (1978), no qual a autora defende que o enquadramento constitui uma característica essencial das notícias, as quais definem a realidade e balizam o entendimento da vida contemporânea. No entanto, seria Todd Gitlin, em seu clássico The whole world is watching (1980) o primeiro autor a propor uma definição clara e sistemática do conceito, que serviria de base para diversas pesquisas sobre enquadramentos da mídia:

Os enquadramentos da mídia ... organizam o mundo tanto para os jornalistas que escrevem relatos sobre ele, como também, em um grau importante, para nós que recorremos às suas notícias. Enquadramentos da mídia são padrões persistentes de cognição, interpretação e apresentação, de seleção, ênfase e exclusão, por meio dos quais os manipuladores de símbolos organizam o discurso, seja verbal ou visual, de forma rotineira. (Gitlin, 1980, p.7 apud Porto, 2004, p.4, grifos no original)

Segundo Entman, ao fornecerem, repetirem e, portanto, reforçarem palavras e imagens que referenciam algumas ideias, mas não outras, os enquadramentos tornam algumas ideias mais salientes no texto, outras menos e outras inteiramente invisíveis. As orientações dos enquadramentos são difíceis de detectar porque muitos artifícios podem parecer "naturais", simples escolhas de palavras ou imagens. A comparação com outros textos, no entanto, mostra que essas escolhas não são inevitáveis ou não-problemáticas, sendo centrais para o modo como a notícia enquadra e interpreta os eventos. Para o autor, o enquadramento não elimina toda informação 
inconsistente, mas por meio da repetição, focalização e associações reforçadoras, palavras e imagens, torna uma interpretação básica mais rapidamente discernível e memorável que outras. Os fatores essenciais do enquadramento são seleção e saliência: "Enquadrar é selecionar alguns aspectos de uma realidade percebida e torná-los mais salientes num texto comunicativo, de modo a promover uma definição de problema particular, uma interpretação causal, avaliação moral e ou recomendação de tratamento" (Entman, 1993).

\section{O estudo do enquadramento}

Já os movimentos sociais e protestos populares têm uma cobertura menor e de cunho negativo, sendo apresentados como tumulto e desordem, enquanto decisões institucionais, mesmo prejudiciais, mas argumentadas, são tidas como legais, institucionais e, portanto, aceitáveis.

A abordagem apropriada para o estudo de matérias jornalísticas é a análise de enquadramento, produzindo resultados que põem em evidência os vieses implícitos na sua produção. Trata-se de uma metodologia que permite salientar o caráter construído da mensagem, revelando a sua inclinação implícita, em textos aparentemente objetivos, imparciais e com função meramente referencial. No entanto, refere-se à natureza do texto jornalístico em geral, numa perspectiva sociocultural e política, não implicando um questionamento da atuação profissional dos autores das matérias. Ao desenvolver a análise, o pesquisador identifica as estratégias textuais e representações contidas em um corpus, podendo estabelecer, por exemplo, contrastes entre coberturas diferentes, as quais, em uma simples leitura, podem parecer semelhantes.

Apesar de o enquadramento constituir uma abordagem surgida no ambiente acadêmico norte-americano, Porto (2004) observa que, desde 1994, esse enfoque recebe atenção crescente de pesquisadores brasileiros, relacionando diversos trabalhos realizados aqui, principalmente sobre a cobertura jornalística de eleições e de movimentos sociais. 
No entanto, excetuando o trabalho desse autor, desconhecemos, na bibliografia brasileira, desenvolvimentos teóricos sobre o conceito.

Para levantar os enquadramentos pela imprensa, Semetko \& Valkenburg (2000) entendem que existem duas abordagens mutuamente exclusivas: a indutiva e a dedutiva. A primeira implica analisar as matérias jornalísticas sem uma grade prévia, de modo a revelar a gama de enquadramentos que se apresentam. Já a abordagem dedutiva envolve a definição prévia dos enquadramentos, buscando verificar sua ocorrência em uma amostra de notícias. Scheufele (1999) diz que o enquadramento é uma forma de construtivismo social, sendo que os meios dispõem os quadros de referência para os leitores, com os quais eles interpretam e discutem eventos públicos. Os enquadramentos dos meios provocam uma "retorção" (spin) no direcionamento da história.

O sociólogo William Gamson e seus colegas, em diversos trabalhos dos anos 1980 e 1990, formaram uma tradição de pesquisa própria sobre o enquadramento, examinando temas políticos como portadores de uma cultura, ou seja, um discurso que se modifica no decorrer do tempo e que apresenta interpretações e significados de fatos relevantes. Em muitos desses temas, existe uma competição entre "pacotes interpretativos", tendo no centro um enquadramento, ou seja, "uma ideia central organizadora" que atribui significados específicos aos eventos, estabelecendo uma conexão entre eles e definindo a natureza das controvérsias políticas. Assim, as questões políticas são caracterizadas por disputas simbólicas entre diferentes interpretações, expressas em metáforas, slogans e imagens empregadas nos discursos dos diversos agentes (Porto, 2004).

Para D'Angelo (2002), os pesquisadores interessados no estudo da construção do enquadramento pelos meios assinalam as palavras e imagens associadas a ele, em um determinado corpus textual. Em seguida, identificam intenções jornalísticas, valores de notícia, estruturas discursivas, conteúdos e formatos que integram palavras e imagens de uma notícia, de modo a construir um determinado enquadramento. Analistas chamam esses elementos constitutivos dos enquadramentos de dispositivos de enquadramento. D'Angelo 
indica, na bibliografia a respeito, uma série de dispositivos que foram propostos para estudar uma variedade de eventos analisados. Assim, Gitlin (1980), estudando a cobertura noticiosa sobre uma entidade estudantil para a sociedade democrática, observou dispositivos de enquadramento como trivialização, polarização, ênfase no dissenso interno, marginalização. Entman (1993) considera os enquadramentos derivados da forma como os assuntos ou eventos são transportados pelos dispositivos, os quais definem problemas, fazem diagnósticos, julgamentos morais e sugerem soluções. Iyengar \& Kinder (1987), investigando o enquadramento da responsabilidade no noticiário, trataram de três dispositivos em coberturas sobre problemas sociais, nas quais a) o presidente era responsável pela causa e solução do problema (condição aumentada); b) outros agentes eram responsáveis pelo problema (condição de desconto), e c) nenhuma pessoa identificável era responsável (condição agnóstica). Neumann et al (1992) identificaram enquadramentos baseados em palavras que ora sugeriam interesse humano, ora conflito, ao longo dos quais se definiam ou uma política ou um problema social. De maneira parecida, Price et al (1997) identificaram três novos enquadramentos, chamados conflitos, interesse humano e consequência, com base em expressões da reportagem que refletiam esses valores de notícia. Semetko eValkenburg (2000), num estudo sobre a imprensa holandesa, identificaram quatro enquadramentos frequentes:

- Enquadramento de conflito. Trata-se de um dos mais frequentes enquadramentos identificados nas pesquisas, especialmente nas coberturas das campanhas eleitorais, quando se reduz o debate complexo à oposição simplista. A ênfase no conflito tem levado os meios a serem responsabilizados pelo cinismo público e à desconfiança dos líderes.

- Enquadramento de interesse humano. Destaca o lado emocional envolvendo seres humanos, personalizando e dramatizando a notícia.

- Enquadramento das consequências econômicas. Enfoca um evento em relação aos seus resultados econômicos para grupos, indivíduos e países. 
- Enquadramento da responsabilidade. Atribui a responsabilidade por um problema ao governo, a um grupo ou ao indivíduo.

Observa-se, portanto, uma variedade de concepções dos dispositivos de enquadramento, sendo que os pesquisadores - devido à natureza competitiva do campo de pesquisa - são encorajados a usar métodos analíticos diversificados, como a análise de conteúdo e a análise do discurso, na busca dos dispositivos de enquadramento nas notícias (D’angelo, op. cit.).

\section{Enquadramento e hegemonia}

Carragee \& Roefs (2004) defendem que os enquadramentos expressam a distribuição do poder social e político, conectando-se dessa forma à hegemonia ideológica. Os enquadramentos podem dominar de tal forma o discurso, a ponto de serem tidos como senso comum ou descrições transparentes dos fatos, em vez de interpretações. Para os autores, os enquadramentos são patrocinados por múltiplos atores sociais, incluindo políticos, organizações e movimentos sociais, e as reportagens seriam como fóruns para disputas entre enquadramentos concorrentes, nos quais atores políticos competiriam pela construção social da realidade, por meio de suas definições dos assuntos. No entanto, os enquadramentos das elites são geralmente favorecidos, devido a seus recursos econômicos, à centralização da coleta de notícias em instituições e à tendência dos repórteres a atribuir maior credibilidade a fontes oficiais do que aos seus desafiadores. Por isso, o autor atribui muita importância, nas pesquisas sobre o enquadramento, à análise das questões ligadas ao poder social e político.

Mc Leod \& Detember (1999), consideram que está bem documentado, em pesquisas realizadas nos Estados Unidos, o favorecimento do jornalismo ao status quo e a existência de um "paradigma de protesto", pelo qual reportagens sobre manifestações públicas tendem a focalizar a aparência dos manifestantes, em vez de suas posições, a enfatizar ações violentas, opô-los à polícia e desmerecer 
sua efetividade. As estruturas narrativas, a confiança nas fontes e definições oficiais e outras técnicas de deslegitimação, marginalização e demonização das manifestações foram identificadas pelo autor nos meios norte-americanos. Bennett e colaboradores (2004), estudando a cobertura jornalística das reuniões do Fórum Econômico Mundial, entre 2001 e 2003, mostraram que o noticiário do New York Times, embora tenha dado grande destaque aos protestos contra o encontro, representou os manifestantes contrários ao Fórum como, na sua maioria, anônimos que ameaçavam a ordem civil violentamente, apesar de poucos distúrbios terem ocorrido efetivamente.

Os enquadramentos não são estáticos, mas se desenvolvem ao longo do tempo, à medida que os jornalistas redefinem os assuntos e as elites reestruturam suas próprias definições, em razão da mudança das condições políticas, absorvendo ou cooptando enquadramentos dos desafiadores. Assim, alguns assuntos e seus enquadramentos podem mudar do campo inconteste para o campo contestado do discurso jornalístico, por meio dos esforços de desafiadores, entre os quais se encontram os movimentos sociais. Em razão desses desafios e porque o consenso da elite às vezes entra em crise, as notícias podem conter inconsistências, o que sublinha a necessidade de abandonar definições mecânicas de hegemonia, já que contradições e enquadramentos oponentes, às vezes, aparecem nos textos. Os movimentos sociais estão entre os mais importantes desafiadores dos valores hegemônicos e sua habilidade de fazê-lo depende da sua eficácia em influenciar o discurso dos meios. Apesar da assimetria do poder de influenciar o processo de enquadramento e da dificuldade de moldar o noticiário, os movimentos sociais, às vezes, conseguem colocar alguns elementos de seus enquadramentos no discurso dos meios (Carragee \& Roefs, 2004).

\section{Efeitos sobre a audiência}

Scheufele (1999) classifica as abordagens de pesquisa do enquadramento em dois tipos: enquadramento do assunto pelos meios 
(media frames) ou enquadramentos individuais. Enquanto o primeiro tipo se refere ao enquadramento como propriedade dos textos jornalísticos, a segunda modalidade focaliza os enquadramentos dos leitores das reportagens, dando um passo adiante das formulações iniciais, abrindo uma nova linha investigações de tipo experimental.

Esses novos estudos têm revelado que os enquadramentos podem ter consequências sobre a forma como as audiências percebem e compreendem um assunto ou evento, podendo até mesmo alterar suas opiniões (Shen \& Edwards, 2005). Os resultados têm sido estudados sob a denominação de "efeitos de enquadramento" e ocorrem porque as pessoas teriam a tendência para empregar "atalhos cognitivos" ou heurísticos para processar a informação, baseando-se nas informações disponíveis para fazerem seus julgamentos. Assim, se os meios noticiosos enfatizam determinada informação sobre um assunto, ela se torna acessível à audiência e pode afetar opiniões e atitudes. Mc Leod \& Detenber (1999) analisando os efeitos do "paradigma de protesto", um tipo de enquadramento que leva a audiência a desenvolver impressões sobre pessoas e assuntos relacionados a uma manifestação pública, concluíram que as variações em termos do nível de apoio ao status quo em reportagens de televisão produziram efeitos de enquadramento em relação à maior ou menor identificação dos leitores com participantes do protesto, apoio aos seus direitos expressivos, crítica da polícia, efetividade percebida, avaliação do apoio público percebido e noticiabilidade do protesto.

Mas, simultaneamente, o processamento da informação das pessoas e a interpretação da realidade sofrem a influência de estruturas de sentido preexistentes, os chamados "esquemas" mentais. Citando Entman (1993), Scheufelle diz que os enquadramentos individuais são conjuntos (clusters) de ideias que organizam o processamento da informação. Shen \& Edwards (op. cit.) afirmam que as pessoas usam seus valores básicos para se posicionarem politicamente, por isso, políticos e meios de comunicação tendem a enquadrar os assuntos em torno de certos valores compartilhados, tais como liberdade, igualdade, individualismo econômico, democracia, capitalismo e humanitarismo. Em um estudo sobre a reforma do sistema de previ- 
dência, os autores encontraram evidência de que os valores preexistentes dos leitores, em relação ao humanitarismo e individualismo, interagiam com os enquadramentos de textos atribuídos à imprensa, afetando suas respostas. Eles explicaram esses resultados com base na teoria da acessibilidade: valores importantes e frequentemente usados estão permanentemente disponíveis, de modo que quando ativados pelas matérias jornalísticas passam a ter um papel decisivo na interpretação e julgamento da informação. Eles defendem que sua descoberta estabelece uma ligação entre valores individuais e enquadramentos dos meios, dependendo dos valores envolvidos e da sua importância para os leitores.

D’Angelo (2002) diz que o fluxo de efeitos de enquadramento envolve a mediação de processos intervenientes (como discursos oficiais, candidatos, movimentos sociais) sobre os enquadramentos de audiência, originando opiniões de pessoas em suas conversas, relacionando-se com conhecimentos anteriores. Esse fluxo indica que os enquadramentos não são de mão única. Por exemplo, os movimentos sociais procuram obter a atenção do noticiário e, em grande parte, são modelados pela cobertura jornalística, mas os discursos dos movimentos sociais interagem com os enquadramentos de notícias, a fim de atenuá-los e comunicar a visão do grupo.

\section{Paradigmas do enquadramento}

D’Angelo (2002) entende que não há um paradigma único para as pesquisas de enquadramento, mas três: o paradigma cognitivo, cuja imagem é a de negociação; o crítico, cuja imagem é a de dominação, e o construcionista, cuja imagem é a de cooptação.

$\mathrm{O}$ paradigma cognitivo considera que a cobertura noticiosa se torna um enquadramento acessível que os indivíduos usam, de modo que a informação disponível ativa o conhecimento anterior, ajudando o leitor a tomar decisões e a formar interpretações. A ideia de negociação, implicada nesse paradigma, ocorreria no contato entre o enquadramento noticioso com os conhecimentos anteriores 
do indivíduo, que formam estruturas semânticas organizadas como esquemas de interpretação. Assim, o conhecimento anterior é o mediador do poder dos enquadramentos, num contexto de tomada de decisão e de avaliação. Porém, os enquadramentos noticiosos também criam associações semânticas nos esquemas individuais, de modo que proposições textuais, nas quais estão codificados os enquadramentos, interagem com o conhecimento prévio, fornecendo a base para atualização dos esquemas.

O paradigma crítico considera os enquadramentos resultado de rotinas de captação de notícias, pelas quais jornalistas, ao produzirem informações sobre assuntos e eventos, fazem-no segundo a perspectiva de valores sustentados por elites econômicas e políticas. No paradigma crítico, os enquadramentos dominam o noticiário e também as audiências. Com base nesse paradigma, Martin \& Oshagen (1997, apud D'Angelo, 2002) examinaram a cobertura noticiosa sobre o fechamento de uma fábrica da General Motors, retratando a adaptação das pessoas às dificuldades como decorrentes de decisões corporativas necessárias. Para os autores, o noticiário atua no sentido de enquadrar as relações sociais hegemônicas, apresentando a redução industrial como inevitável e mostrando que a cumplicidade das pessoas é importante para o sucesso do programa. Para os autores, enquadramentos ligados ao processo hegemônico limitam a amplitude do debate e restringem seu potencial para a esfera pública democrática.

Já o paradigma construcionista sustenta que os jornalistas são processadores de informação que criam pacotes interpretativos, a partir das posições de fontes com investidura política, a fim de refletir e acrescentar-se à cultura do assunto. Nesse processo, os enquadramentos constrangeriam a consciência política de indivíduos, opor-se-iam aos objetivos dos grupos ligados a movimentos sociais, estabeleceriam parâmetros para os debates políticos - não necessariamente de acordo com procedimentos democráticos. Por isso, a imagem paradigmática do construcionismo é a cooptação. Os enquadramentos podem existir por muito tempo e constituem as "ferramentas" usadas pelos cidadãos para formar suas opiniões. Um exemplo seria o enquadramento da energia nuclear como "pro- 
gresso" pelos meios norte-americanos, entre 1945 e 1970 (Gamson \& Modigliani, 1989, apud D’Angelo, 2002).

Comparando análises de enquadramento realizadas, D'Angelo (op. cit.) considera que os pesquisadores tendem a sintetizar ideias de diferentes paradigmas, formando uma abordagem multiparadigmática.

\section{Agendamento, enquadramento e democracia}

As representações dos meios noticiosos configuram-se, especialmente, como agendamento e enquadramento. Esses conceitos, construídos sobre bases teóricas distintas e adotando métodos analíticos próprios, inspiram as análises da influência e do conteúdo jornalístico nas últimas décadas, em diversos países.

$\mathrm{O}$ agendamento, como vimos, indica que a ordem de certos temas ou eventos nos meios noticiosos exerce uma influência sobre a ordem dos temas de preocupação dos leitores, num processo denominado transferência de saliência, o que indica a importância do agendamento na formação da opinião pública. A agenda dos meios e dos leitores, no entanto, não exerce necessariamente influência sobre a agenda do governo, ou seja, sobre ações públicas efetivas a respeito dos problemas indicados, limitando-se a produzir, na maioria das vezes, manifestações retóricas protocolares, que provavelmente têm apenas uma finalidade contemporizadora. Isso significaria que o papel dos meios é muito mais de caráter simbólico, pautando as questões para outros atores sociais, geralmente no âmbito dos discursos, em vez de deflagrar políticas públicas ou ações específicas. Haveria uma independência relativa entre políticas públicas e agenda mediática, o que limitaria muito o poder político dos meios. Esse é um tema para uma pesquisa comparando a agenda mediática, ao longo de um determinado período, com as ações dos poderes Executivo e Legislativo, por exemplo. Uma hipótese é de que os problemas agendados pelos meios noticiosos são, na sua maioria, crônicos, revelando uma lentidão dos órgãos responsáveis em encaminhar sua solução. 
Reconhecendo esse fato como um dado, passou-se a indagar sobre as forças que atuam na constituição da agenda dos meios, sugerindo-se estabelecer uma relação entre critérios de noticiabilidade e agenda mediática. Toda uma série de questões se desenha aqui, especialmente a partir da hipótese de que os critérios de noticiabilidade são, em larga medida, arbitrados pelos meios de comunicação. No caso do Brasil, em que se observa um caráter conservador dos meios (Azevedo, 2006), pode-se conjeturar que o noticiário sobre determinados acontecimentos possa ser expandido ou minimizado deliberadamente para atender a posições políticas ou interesses de grupos ou setores do establishment.

No caso dos diferentes enquadramentos que podem ser assumidos pelas matérias jornalísticas, vimos que eles correspondem às percepções distintas dos eventos, num ambiente de liberdade, competição e conflito, marcas de uma sociedade democrática, sendo resultante da tensão das interpretações que marca essa realidade. No entanto, um exame mais crítico poderá revelar que, no caso dos meios hegemônicos, a diferença de enquadramentos se dá numa faixa limitada do espectro das opiniões, deixando de lado uma gama de interpretações, que corresponderiam à visão de outros segmentos sociais. Os estudos do enquadramento, além disso, tendem, como vimos, a revelar uma concentração das representações que valorizam o status quo em detrimento da contestação. Dessa maneira, os enquadramentos balizam o debate, marcando os limites, não de todas as definições de realidades em disputa, como escreveu Gitlin, mas de algumas delas, preferencialmente aquelas que não colocam diretamente em xeque o status quo.

Na combinação de agenda mediática e enquadramento, poderíamos cogitar que os meios noticiosos formam um painel parcial da sociedade, geralmente super-representando temas de interesse de classe média, de onde provêm os leitores e consumidores dos produtos anunciados nos meios, apresentando esses temas segundo certos enquadramentos. Temas de interesse das maiorias podem aparecer no noticiário, mas com menor frequência, sendo geralmente motivados por acontecimentos pontuais (calamidades, acidentes, crise educa- 
cional ou sanitária) ou então sob a forma de ameaças, como o crime, ocupações de terras ou de instalações, greves e outras ações. Por sua vez, estas últimas podem ter sido planejadas exatamente com a finalidade de serem agendadas, revelando estratégias dos movimentos sociais para alcançarem visibilidade mediática.

\section{Referências bibliográficas}

AZEVEDO, F. A. Democracia e mídia no Brasil: um balanço dos anos recentes. In: GOULART, J. O. (Org.) Mídia e democracia. S. Paulo: Annablume, 2006.

D'ANGELO, P. News framing as a multiparadigmatic research program: a response to Entman. Journal of Communication. December, 2002.

ENTMAN, R. M. Framing US Coverage of International News: contrast in narratives of the KAL and Iran Air incidentes. Journal of Communication, 41 (4), Autumn, 1991.

FUKS, M. Definição de agenda, debate público e problemas sociais: uma perspectiva argumentativa da dinâmica do conflito social. Revista Brasileira de Informação Bibliográfica em Ciências Sociais. Rio de Janeiro, n. $49,1^{\circ}$ semestre de 2000.

GAMSON, W. A., MODIGLIANI, A. Media discourse and public opinion on nuclear power: a constructionist approach. American Journal of Sociology, 95, 1-37.

LIMA, V. A. de. Televisão e poder: a hipótese do cenário de representação da política, CR-P. Comunicação E Política, Nova Série, v.1, n.1, p 5-22, ago./nov.1994.

CR-P: novos aspectos teóricos e implicações para a análise política. Comunicação Ė política, nova série, v.1, n.3, p 95-106, abr./jul. 1995. Mídia, teoria e política. São Paulo: Fundação Perseu Abramo, 2001.

MARTIN, C. R., OSHAGEM, H. Disciplining the workforce: The news media frame a General Motors plant closing. Communication Research, 24, 669-97.

MC COMBS, M. Setting the agenda. Cambridge: Polity Press, 2004.

MCLEOD, D., DETENBER, D. H. Framing effects of television news coverage of social protest. Journal of Communication.Summer, 1999, p.3-23.

MIGUEL, L. F. Representação política em 3-D: elementos para uma teoria ampliada da representação política. Revista Brasileira de Ciências Sociais. v.18 n.51. São Paulo, Fev. 2003. 
PIGNATARI, D., Informação, Linguagem, Comunicação. São Paulo: Ateliê Editorial, 2003.

PORTO, M. P. Enquadramentos da mídia e política. In: RUBIM, A. A. (Org.) Comunicação e Política: conceitos e abordagens. Salvador: EdUFBA, 2004. p.73-104.

SEMETKO, H. A., VALKENBURG, P. M. Framing european politics: a content analysis of press and television news. Journal of Communication. Spring, 2000, p.93-109.

SHEN, F., EDWARDS, H. H. Economic individualism, humanitarism and welfare reform: a value-based account of frame effects. Journal of Communication.Dec. 2005, p.795-808.

SCHUDSON, M. The power of the news. Cambridge/Londres: Harvard University Press, 2003.

SOUZA, J. P.As notícias e os seus efeitos. Porto: 1995. Disponível em: http://bocc.ubi.pt

TRAQUINA, N. Teorias do jornalismo. Porque as notícias são como são. V.1. Florianópolis: Insular, 2004.

WOLF, M. Teorias da comunicação de massa. Lisboa: Presença, 1987. 

PARTe II

\section{DEMOCRACIA E JORNALISMO}





\section{4 \\ Democracia: A palaVRa e os SENTIDOS ${ }^{1}$}

\section{Introdução}

O século XX foi marcado pela derrota do fascismo e do nazismo, na sua primeira metade, e pelo desaparecimento, no final do século, da maioria dos regimes políticos denominados "socialismo real", que vigoraram durante décadas em sociedades importantes, pelo fim das ditaduras de direita em países latino-americanos e o retorno a governos representativos. A democracia tornar-se-ia, assim, a agenda política consensual do século XXI, representando, ela própria, uma das finalidades da atividade política, na medida em que é uma garantia de respeito aos direitos, de expressão dos conflitos, de retificação dos caminhos errados, de igualdade na punição dos erros, mesmo que esses valores sejam entendidos em termos ideais. Não há regimes alternativos à democracia que sejam aceitos majoritariamente no campo da discussão política contemporânea, no qual as formas autoritárias de governo ou de organização social tendem a ficar isoladas.

1 Versões deste trabalho foram debatidas no III Seminário Internacional LatinoAmericano de Pesquisa da Comunicação, realizado pela Alaic, em 2005, na ECA-USP, São Paulo, e no III Simpósio Brasileiro de Psicologia Política, realizado na Unesp de Bauru em 2005. 
Neste capítulo procuramos enfrentar os sentidos desse conceito, argumentando que a democracia aparece como uma conquista social cuja manutenção interessa mais particularmente às camadas subalternas da sociedade. Apesar dessa concordância com o regime, é preciso reconhecer as limitações próprias da democracia representativa e as deformações que ela sofre na sua concretização, por força de inúmeras variáveis sociais, econômicas e culturais. Não temos a pretensão de, no âmbito deste capítulo, abordar exaustivamente as dimensões do conceito e a complexa problemática teórica da democracia, nem de examinar em pormenor diversas teorias sobre ela, mas tão somente trazer algumas referências conceituais suficientes para balizar as discussões sobre comunicação e democracia que se farão ao longo do trabalho.

\section{Assimetrias de poder}

Durante a maior parte da História, vigoraram nas diversas sociedades as aristocracias, ou seja, a desigualdade social e política constitutiva, construída a partir da ascendência familiar e de genealogias nobres. Essa situação foi denominada heteronomia, ou seja, trata-se de regimes em que as normas não são debatidas pela sociedade, mas estabelecidas unilateralmente por uma classe ou por categorias de pessoas de posse do comando por ascendência familiar e com base na religião. É extraordinário que somente nos últimos duzentos anos essa situação tenha começado a mudar, com o alastramento das revoluções burguesas, que trouxeram consigo a república ou pelo menos as monarquias parlamentares, que substituíram o poder da nobreza ou o atenuaram. A longa duração histórica das monarquias apenas mostra a força da tradição, da religião e dos aparelhos coercitivos do Estado na manutenção a longo prazo de uma distância social extrema e uma desigualdade política radical entre seres humanos.

A implantação de regimes republicanos e dos parlamentos nos regimes monárquicos criou uma situação nova, na qual os indivíduos lutaram para adquiriam um estatuto político idêntico perante os Es- 
tados Nacionais, deixando de ser súditos para se tornarem cidadãos. A partir desse momento, passa a travar-se uma luta regulamentada pelo controle do aparelho do Estado, inaugurando propriamente o campo da política, como um espaço de competição e disputa pelo poder, por meio do voto, conquistado por meios simbólicos como a retórica e a ideologia e tendo como instrumento privilegiado de ação os partidos políticos.

O valor da noção de democracia pode ser posto em evidência, $a$ contrario, pelas consequências trágicas das experiências autoritárias do século XX. Regimes totalitários surgidos na chamada "era das tiranias”, iniciada no final da Primeira Guerra Mundial, produziram resultados catastróficos em termos humanos, indicando que relações assimétricas entre o indivíduo e o Estado todo-poderoso, ainda mais quando ele dispõe dos recursos das modernas tecnologias, não podem produzir boas sociedades. O esmagamento dos direitos humanos, as guerras, as injustiças, as perseguições, os abusos de toda ordem contra os indivíduos, deportações, campos de concentração, injustiças, os assassinatos, a interrupção do desenvolvimento intelectual, o irracionalismo e o genocídio foram consequências históricas reiteradas do despotismo dos regimes policiais de Estados contemporâneos. Por isso, O’Donnell (1999), diz que "a despeito de suas limitações o regime democrático é uma conquista valiosa”.

a existência desse tipo de regime e das liberdades que lhe são simultâneas, apesar das muitas deficiências persistentes em outras esferas da vida política e social, implica uma enorme diferença em relação ao regime autoritário. No mínimo, essas liberdades criam a possibilidade de usá-las como base de proteção ou de habilitação para a busca de ampliar os direitos existentes ou obter novos. (O’Donnel, 1999)

Huntington (apud Castro Santos, 2001) considera que houve três ondas de democratização. A primeira, marcada pelo aumento expressivo da população masculina com direito a voto, teve início na década de 20 do século XIX, prolongando-se até 1926, quando se encerra simbolicamente com a marcha de Mussolini sobre Roma. 
Há, em seguida, um período de retrocesso, marcado pela ascensão dos regimes fascistas e antiliberais. A segunda onda democratizante viria com a vitória dos Aliados na Segunda Guerra e o começo da descolonização, mas seria revertida, a partir de 1960, pela sucessão de golpes militares, em especial na América Latina, inaugurando um longo período ditatorial. Com o fim dos regimes autoritários na Europa e na América Latina, estaríamos na terceira onda de democratização, cujo marco simbólico é a Revolução dos Cravos, em Portugal, no ano de 1974. Esta última onda teria atingido todos os continentes, sendo muito maior que as anteriores. Durante a primeira onda de democratização havia 29 países democráticos, correspondendo a 45,3\% do total de Estados no mundo. Durante a segunda onda, os países democráticos eram 36, ou 32,4\% dos países. Já em 1999, 120 países, 62,5\% de um universo de 192, eram considerados formalmente democráticos, apresentando sistemas democráticos constitucionais, com eleições competitivas e multipartidárias, em contraste com apenas $41 \%$ uma década antes (Castro Santos, op. cit.).

Apesar da amplitude da última onda de democratizações, há, ainda hoje, diversas sociedades autoritárias, mas seus regimes não se apresentam como modelos para os demais, nem são vistos pelo resto do mundo como referência desejável para o desenvolvimento futuro. São situações peculiares, resultantes de desenvolvimentos históricos próprios, que não constituem modelos universalizáveis de organização política, nem se baseiam em doutrinas generalizáveis ou, sequer, defensáveis.

Na América Latina, após as sangrentas ditaduras dos anos 70, os governos democráticos passaram a predominar a partir dos anos 80 . O Brasil retornou à democracia, em 1985, com a posse do primeiro governo civil, embora ainda eleito indiretamente, encerrando vinte anos de regime militar. A redemocratização foi tarefa de uma geração e contou com a participação tanto de trabalhadores quanto de estudantes, professores, intelectuais, da classe média, enfim. Muitos perderam seus direitos nessa luta, outros foram exilados, presos, torturados e mortos, de modo que a democracia brasileira é um bem conquistado com muito sacrifício e, apesar de seus problemas, há um 
reconhecimento tácito das diversas classes, categorias e grupos da sociedade de que os avanços políticos só poderão ocorrer por meio seu aprimoramento, e não pela sua substituição por qualquer modalidade de regime que venha a suprimir direitos políticos, civis ou sociais.

Para Castro Santos (2001), "implícita ou explicitamente, todos manifestam a 'esperança' de que os sistemas políticos avaliados venham a tornar-se democráticos ou consolidados. O forte viés normativo pró-democracia é inequívoco” (op. cit., p.732). Apesar desse consenso, a autora adverte para o que denomina "postura naïve e missionária, quando não militante, mas certamente ideológica, na defesa e promoção da democracia no mundo", à qual se adicionaram pressões declaradas do FMI, do governo dos Estados Unidos, com a ajuda da União Europeia, da OEA e da ONU:

É importante, portanto, considerar democracia como pressão externa, expressão da hegemonia ocidental, independentemente da preferência dos cidadãos e governantes dos países em tela. A ideia de modelo ideal de democracia, à moda dos países industrializados ocidentais nos mais diversos ambientes histórico-culturais que compõem o mundo em desenvolvimento, é criticada por parte relevante da literatura recente sobre processo de democratização. Embora a referência comum continue sendo a democracia procedural na tradição de Schumpeter/Dahl, esse segmento da literatura fala de tipos de democracia, de democracia delegativa, graus e limites mínimos de democracia e regimes híbridos, geralmente levando em conta os distintos contextos histórico-culturais das democracias emergentes. (idem, p.733)

A democracia envolve um regramento aberto e neutro capaz de viabilizar a luta política sem uso da força, mantendo os conflitos no campo simbólico discursivo dos parlamentos, dos meios de comunicação, das campanhas eleitorais, dos atos públicos, das manifestações pacíficas, passeatas e reuniões, das negociações e votações. O regime deve garantir a igualdade de condições políticas, mas ao ser implantado em sociedades social e economicamente desiguais, relativiza o 
ideal de igualdade política, considerado abstratamente, na medida em que assimetrias econômicas entre os segmentos sociais podem comprometer essa isonomia jurídica.

Considerando a série de peculiaridades históricas nacionais representadas, entre outros critérios, pelo grau de desenvolvimento das forças produtivas, o intervalo das desigualdades sociais e econômicas, a adesão social ao regime (cultura política), fala-se da "democracia brasileira", da "democracia norte-americana" etc., atribuindo um conteúdo concreto de experiências nacionais ao projeto democrático de cada sociedade. Dessa maneira, embora a democracia possa expressar um conjunto de princípios universais, sua concretização histórica é sempre peculiar e diversa no tempo e no espaço, especificando-se a cada vez em projetos vivenciados coletivamente, em conjunturas variáveis, que lhe dão um conteúdo e uma forma próprias.

\section{As teorias e as práticas democráticas}

Apesar do consenso sobre o valor da democracia, um estudo comparativo entre autores que trataram do tema, nos últimos dois séculos (como Rousseau, os federalistas, Tocqueville e os marxistas), revelaria muito mais um conceito em disputa do que um sentido universal (Freitas, 2006). Etimologicamente, democracia significa governo do povo e a sua implantação original deu-se em Atenas no século 5 a. C., mas há uma grande diversidade de modos de interpretar o seu significado atual. Os gregos nos deram a palavra democracia, mas não um modelo (Birch, 1993).

Na realidade, a democracia grega representou um episódio muito exclusivo e também muito breve de algumas cidades gregas, que não foi imitado por outras sociedades da Antiguidade. Nas cidades gregas que a adotavam, todos os homens, adultos e livres, reunidos em praça pública, podiam participar das decisões, geralmente relativas à realização de festas coletivas e atribuição de encargos. Era um regime de iguais, mas excluía as mulheres, os escravos e estrangeiros. Estudiosos eruditos observam que as cidades-estado da Grécia 
não ultrapassavam algumas dezenas de milhares de habitantes, de modo que os cidadãos que participavam dessas reuniões, apesar de poderem formar um grande número, o faziam pessoalmente, sem representantes (Dahl, 2001).

As diferenças entre as sociedades contemporâneas e as da Grécia no século V a. C. tornam obrigatória a adequação do conceito antigo para os tempos atuais. As sociedades atuais têm populações muito maiores, são muito heterogêneas e mais complexas. Mas, além disso, há um consenso entre os autores de que a forma da democracia contemporânea deve muito mais aos desenvolvimentos políticos realizados a partir de instituições e práticas medievais europeias, por meio das quais os governantes buscavam a aprovação de suas políticas, em particular a elevação de impostos, por representantes dos três "estados": a nobreza, o clero e a burguesia. As assembleias desses representantes estão na origem dos parlamentos atuais. Embora não corresponda ao conceito contemporâneo de democracia, é importante observar que as assembleias estabeleciam um limite ao poder real, especialmente após a chamada Revolução Gloriosa, ocorrida na Inglaterra, no século XVII, que fortaleceu o Parlamento em face da realeza.

No século XVIII, ocorrem outros desenvolvimentos importantes, como o Iluminismo e as revoluções americana e francesa, das quais surgem os conceitos de direitos naturais e igualdade política. Apesar disso, a democracia norte-americana, como se sabe, continha restrições inaceitáveis nos dias de hoje, como os direitos políticos determinados pela propriedade, a exclusão das mulheres e dos escravos, estes últimos considerados como bens e não como cidadãos. A principal preocupação das instituições imaginadas pelos fundadores da nação norte-americana era a criação de mecanismos capazes de garantir a centralização do poder na nova nação, evitando, porém, o risco do despotismo (Freitas, 2006). A partir do século XIX, parlamentos com representantes legislativos eleitos passaram a ser instituições centrais dos governos, embora a palavra democracia fosse ainda considerada um termo revolucionário ou radical, havendo diversos procedimentos para limitar o sentido de povo a certos grupos considerados qualifica- 
dos (Williams apud Schramm, 2007). As eleições eram censitárias no início, ou seja, apenas homens livres com certa renda podiam votar, mas os direitos políticos foram se estendendo aos cidadãos adultos, embora o voto feminino só viesse tardiamente, no século XX, como resultado do movimento sufragista das mulheres.

No esforço de caracterizar a democracia contemporânea, há duas formas diferentes de proceder: uma, normativa ou idealística, busca estabelecer os ideais, valores e princípios democráticos; a outra, empírica, parte da observação da prática política das sociedades consideradas democráticas para, indutivamente, conceituar a democracia (Birch, 1993).

$\mathrm{Na}$ abordagem normativa, teóricos políticos norte-americanos, com base nos textos dos chamados fundadores da República, definem a democracia de três modos diferentes: a) o populista, que a trata em termos de governo do povo; b) o pluralista, que a define pela competição entre grupos de pressão e c) o modo institucional, que a vê em termos de instituições e processos.

O modo populista está assentado na crença na soberania popular, pela qual o poder supremo está nas mãos do povo, o que revela certo ceticismo dos fundadores com relação aos políticos, por mais iluminados estadistas que fossem. Assim, eleições frequentes seriam necessárias para manter os políticos em xeque, como forma de evitar a corrupção de suas funções. Apesar dessa crença na soberania popular, os teóricos e líderes da revolução americana não consideravam o sistema que implantaram uma democracia, devido a uma aversão à ideia de governo dos mais pobres, preferindo considerá-lo republicano, expressando a tradição do século XVIII (Graeber, 2005; Birch, 1993).

A linhagem pluralista, pelo contrário, entende que o governo democrático é uma arena para o conflito entre grupos organizados, que expressam interesses importantes e garantem a realização de compromissos que levem em conta esses interesses. Uma corrente teórica contemporânea, o pluralismo radical, considera que o conflito, em vez de ser um problema para a democracia, é uma de suas virtudes (Cunningham, 2001). Para os autores dessa corrente, não apenas o conflito é inevitável na vida social e política, como o seu reconheci- 
mento e institucionalização pela cultura e instituições democráticas é uma defesa contra a autocracia. A esse respeito, é inevitável lembrar que formas de governo antidemocráticas condenam os conflitos sociais, como fazia o fascismo, que pretendia suprimir as contradições, em nome uma suposta unidade nacional, acima das classes.

Ribeiro (2002) considera, nesse sentido, que a democracia é também um meio de resolver conflitos, porque aceita a divergência, renunciando à unanimidade. Ao encaminhar a solução dos conflitos por meio do voto, a democracia torna a aceitação dos derrotados mais fácil do que quando se usam outros procedimentos, sendo, por isso, capaz de produzir relações sociais melhores, mais pacíficas e maior cooperação. Os procedimentos democráticos significam que somos incapazes de definir racionalmente a melhor alternativa para todos, havendo uma disputa entre posições antagônicas sobre assuntos controvertidos de natureza política e social, sendo, portanto, preferível resolvê-los pela discussão, argumentação e pelo sufrágio.

Por último, o modo institucional de conceituar a democracia focaliza as instituições e os procedimentos, como governo parlamentar e as eleições livres e universais. A democracia implantada nos Estados Unidos instituiu a representação política e a separação dos poderes, instaurando um modelo que inspiraria as instituições das democracia contemporâneas.

Bobbio (2000), na linha institucional (ou procedimental, como ele escreve), entende que a democracia é o "governo das leis", o conjunto de regras que estabelecem quem está autorizado a tomar as decisões coletivas e com quais procedimentos, sendo fundamental a regra da maioria. Ela se baseia nos direitos de liberdade de opinião e expressão, de reunião e de associação que formaram a base do Estado liberal, pressuposto histórico e jurídico do Estado democrático e sobre o qual se constitui o Estado de Direito. Ribeiro (2002), de forma semelhante, diz que o caráter democrático da política moderna é dado pelos direitos, que exprimem a pressão popular sobre o poder.

Nessa abordagem, vemos que, em termos institucionais, a democracia se realiza por meio da representação, pela qual eleitores escolhem os governantes, ou seja, aqueles que realmente terão o 
poder de decidir. Schumpeter, por exemplo, entende o método democrático como um arranjo institucional para chegar a decisões políticas, em que os indivíduos, para adquirirem o poder de decidir, entram em uma luta competitiva pelo voto da população (1976 apud Kinzo, 2004).

Nessa definição, ou seja, da disputa pela maioria dos votos, a democracia identifica-se com eleições. Por esse critério, a democracia é, apenas, um método que transfere a algumas pessoas o poder de decisão em questões políticas, legislativas e administrativas, por meio de eleições. Como os eleitos é que passam a ter poder, em lugar dos eleitores, na democracia o povo não governa, apenas aceita ou recusa pessoas que se candidatam para governá-lo. Além disso, Schumpeter afirma que os eleitores não sabem o que é melhor para eles em questões públicas, não têm uma vontade expressa, apenas impulsos vagos, equivocados e desinformados. A concepção eleitoral da democracia é bastante difundida, sendo usada para determinar, pelos critérios procedimentais, quais regimes são e quais não são democracias, mas a democracia é, nessa perspectiva, tão somente, um mercado eleitoral, em que os políticos competem pela preferência do eleitorado (Cheibub \& Przeworski, 1997) e seriam regimes democráticos todos aqueles que promovem eleições livres e regulares de seus governantes.

Miguel (2002) salienta a contradição entre a noção original de democracia e essa conceituação mínima, na qual o povo não governa e as decisões são tomadas por uma minoria, geralmente mais rica e informada que a maioria, sobre a qual exerce um papel de liderança. Relaciona a concepção minimalista schumpeteriana ao pensamento elistista de Mosca, Pareto e Michels, lembrando que ela teria um papel na confrontação ideológica com os regimes comunistas durante a guerra fria:

O modelo desenhado por Schumpeter é um retrato bastante fiel dos regimes políticos ocidentais, que permite que eles se apresentem como verdadeiras democracias. Mas é, de fato, um rebaixamento do ideal democrático. Significa a negação da possibilidade de qualquer 
forma substantiva de soberania popular. A participação do cidadão comum é reduzida ao mínimo, ao ato de votar. Schumpeter condena qualquer outra manifestação popular, até mesmo o simples envio de cartas aos representantes, como sendo uma intromissão indevida dos governados nas ações dos governantes. Ao mesmo tempo, o momento central da democracia concorrencial, a eleição, é desprovido de qualquer conteúdo, pois não indica a vontade do povo, nem mesmo a da maioria. (Miguel, 2002, p.502)

O’Donnell admite o elitismo da conceituação schumpeteriana, mas não vê minimalismo nela, defendendo que Schumpeter preconizara outras condições complementares às eleições, entre elas as liberdades de expressão e de imprensa. Ele chama essa definição de realista e restritiva, pois ela "delimita um espaço empírico e analítico que permite distinguir esse tipo de regime de outros, com importantes consequências normativas, práticas e teóricas" (1999). O’Donnell faz complementos à teoria competitiva, acrescentando às eleições livres outros aspectos essenciais à democracia, como inclusividade e universalidade; a existência de um sistema legal para promulgar e garantir pelo menos os direitos e liberdades incluídos na definição de um regime democrático e excluindo a possibilidade de uma pessoa ou instituição declarar-se acima do sistema jurídico.

Dahl (2001) entende que, para que haja uma democracia representativa moderna, são necessárias eleições, mas, além delas, é preciso que existam e funcionem diversas outras instituições políticas básicas, apresentando uma relação bastante abrangente delas:

- Governantes eleitos: os cidadãos elegem seus representantes nos poderes Legislativo e Executivo, delegando a eles poder temporário para as decisões de governo.

- Eleições livres, justas e frequentes: um dos sinais mais peculiares da democracia é a realização de eleições nas épocas previstas, de forma pacífica e sem coerções ou ameaças aos eleitores.

- Liberdade de expressão: a liberdade de expressão é condição para que as pessoas participem realmente da vida política, para que adquiram uma compreensão esclarecida das ações do 
governo. Dahl escreve que para adquirir competência cívica, as pessoas precisam expressar seus pontos de vista, aprender umas com as outras, discutir, decidir, questionar especialistas e políticos. As pessoas devem ter o direito de se manifestar, inclusive sobre questões políticas, fazendo críticas ao governo, ao regime, aos funcionários, à ordem socioeconômica e à ideologia dominante. Finalmente, é pela liberdade de expressão que as pessoas podem influenciar as decisões e ações do governo.

- Fontes de informação diversificadas: esta condição está diretamente ligada à anterior e diz respeito, principalmente, aos meios de comunicação. É uma condição da democracia que os cidadãos tenham acesso a informações independentes, envolvendo jornais, revistas, livros, internet etc.

- Autonomia para associação: os cidadãos precisam ter direito a formar grupos, organizações, entidades, como partidos políticos, sindicatos, até mesmo como forma de obter direitos necessários para o funcionamento das instituições políticas democráticas.

- Cidadania inclusiva: os direitos acima devem ser estendidos a todos os cidadãos adultos residentes permanentemente no país. Historicamente, certas categorias, como as pessoas sem propriedades, os escravos e as mulheres, estiveram excluídas dos direitos políticos. Durante milênios, os direitos em democracias e repúblicas estiveram restritos a uma minoria de adultos, sendo o governo e a vida política assuntos exclusivos de homens. $\mathrm{O}$ conceito de cidadania expressa a ideia republicana crucial de que os membros da sociedade democrática são pessoas com direitos políticos e jurídicos iguais, portadores, cada um, de uma fração da soberania, e não súditos de um monarca.

Para Dahl (2001), além dessas, outras condições ainda são necessárias para a existência da democracia, como o controle dos militares e da política por governantes eleitos; a presença de uma cultura política e de convicções democráticas; a ausência de controle estrangeiro hostil à democracia. O autor alinha também o que chama de condições favorá- 
veis à democracia, como uma economia de mercado moderna e o fraco pluralismo subcultural. Essas condições, desenvolvidas por Dahl, já sinalizam as dificuldades de implantação da democracia em muitos países com tradições culturais despóticas e estruturas sociais desfavoráveis ou que enfrentam conjunturas econômicas críticas, indicando o delicado equilíbrio necessário à permanência de governos democráticos ao longo do tempo. No entanto, ele próprio salienta o paradoxo da Índia, país com problemas sociais crônicos, uma multiplicidade de línguas e variedade subcultural e que, por isso mesmo, tem no regime democrático a única alternativa de manter-se unido e em paz.

Sartori (1994) defende que o processo democrático é sintetizado nas eleições, momento em que, para ele, estamos diante de um "povo governante", mas o voto expressa uma experiência pré-eleitoral, pois computa opiniões, de modo que as eleições promovem um governo baseado na opinião prévia do eleitorado. Eleições sem opinião livre não têm qualquer conteúdo democrático, argumenta o autor, destacando o papel amplo e central que os meios de massa desempenham na formação da opinião pública nas democracias de hoje. Ele indica duas condições capazes de originar uma opinião pública relativamente autônoma: um sistema educacional que não seja voltado à doutrinação e a pluralidade dos centros de informação. Uma opinião pública livre, no seu entender, resulta de uma estruturação policêntrica dos meios de comunicação e de sua interação competitiva, sendo sustentada por essas condições. Daí que uma crítica recorrente à informação nos países democráticos seja a de que o poder de informar é um poder de poucos, distribuído de forma desigual.

Sartori (1994) cita que as pesquisas demonstram um estado de desatenção, falta de interesse, subinformação, distorção perceptiva e ignorância do cidadão comum, lamentando que o público não tenha opinião, mas apenas sentimentos desarticulados. Para ele, três críticas podem ser dirigidas às marcas da informação que o público recebe dos meios: insuficiência; tendenciosidade e pobreza em termos de qualidade. Sartori detém-se na questão da qualidade, argumentando que muitas vezes, por exemplo, a televisão apresenta meias verdades ou coisas inteiramente falsas. 


\section{Democracia como fórum}

Dahl (1997) denomina democratização o processo de progressiva ampliação da competição política e do direito de participação no processo político, ou seja, ampliação da inclusão (menores e mulheres, por exemplo).

À concepção de competição num mercado, representada pela teoria minimalista formulada por Schumpeter, Sales (2005) contrapropõe a perspectiva da democracia como participação num fórum, que seria, segundo ela, expressa pela teoria deliberativa, a qual pressupõe a inclusão nas discussões das pessoas interessadas, destacando-se a relevância da argumentação e do convencimento dos participantes.

Para a autora, o elemento mais importante da democracia deliberativa é a necessidade de o Estado ceder um espaço decisório à participação pública. Nesse sentido, os arranjos deliberativos coincidem com formas ampliadas de participação popular, que contribuiriam para a argumentação em que os atores trazem razões próprias, diferentes daquelas do Estado. A democracia deliberativa, segundo ela, realizar-se-ia nos fóruns entre o Estado e a sociedade, como, por exemplo os conselhos e o orçamento participativo, quando as informações são tornadas públicas, em arranjos deliberativos capazes de experimentar inovações institucionais, revelando diversidade e não unidade. Em conclusão, Sales procura articular as duas perspectivas, defendendo que a interpretação da democracia como mercado não exclui a possibilidade de ela desempenhar também o papel de fórum.

Enquanto a dimensão concorrencial é um procedimento generalizado nas democracias contemporâneas, a participação da sociedade civil nas deliberações é um mecanismo de abertura à intervenção política e, por conseguinte, introduz um elemento de correção da perspectiva minimalista. Porém, para isso, será preciso observar as instaurações históricas concretas da democracia para perceber de que maneira elas implementam essas práticas.

Outra expressão da abordagem deliberacionista da democracia apresenta-se no campo da comunicação de massa, por meio do "intercâmbio de razões em público" propiciada pela rede de opiniões 
publicadas, como defende Maia (2007). Nessa perspectiva, embora reconhecendo diversas limitações, a autora argumenta que são os meios de comunicação que tornam públicas as informações, de modo que os cidadãos possam avaliar os problemas e promover discussões políticas.

\section{Representação e democracia}

Apesar de ser, hoje, fato corriqueiro referir-se aos regimes democráticos atuais como representativos, os autores clássicos como Rousseau e os federalistas não reconheciam essa forma de governo como democracia. Rousseau, por exemplo, entendia que esse tipo de governo não representa a vontade geral, mas a vontade de particulares, na medida em que o parlamento acolhe os conflitos das classes sociais. Sistema que abre a esfera pública para o conflito de interesses, a representação acabaria por transformar o governo no titular da vontade geral (Freitas, s. d.).

Miguel (2003) observa que a democracia baseia-se na ideia de igualdade entre todos os cidadãos, enquanto a eleição implica seleção, ou seja, introduz a ideia de que existem indivíduos mais bem preparados para os cargos públicos, sendo, por isso, um mecanismo aristocrático, destinado a estabelecer uma distinção entre os cidadãos. As instituições representativas, em vez de terem surgido devido à impossibilidade de democracia direta em grandes Estados, teriam sido pensadas desde o início como meio para reduzir a presença popular no governo, deixando-o nas mãos de indivíduos da elite.

Por outro lado, os cidadãos, na verdade, não escolhem seus representantes para promover seus interesses; antes, apenas votam em um candidato dentre aqueles que se apresentam no mercado político. A representação política tem origem no voto, quando eleitores escolhem delegados para decidirem em seu nome. A eleição, além de constituir o meio para a alternância no poder, é o momento de origem da representação e o momento em que os representados julgam seus representantes no mandato anterior, o que vem sendo chamado de responsividade, ou prestação de contas. 
Uma complexidade a mais decorre da organização da competição eleitoral por meio dos partidos políticos: é que os eleitos prestam conta tanto ao eleitorado quanto a seu partido, dando origem ao chamado duplo mandato (Miguel, 2003). Apesar de serem entidades que se interpõem entre os eleitores e os candidatos, Kinzo defende que eles desempenham um papel central na operacionalização da vida política:

Os partidos têm papéis específicos em duas arenas do sistema político: a eleitoral e a decisória. Nesta última, sua atividade está associada à formulação, ao planejamento e à implementação de políticas públicas, participando como atores legítimos no jogo de poder e no processo de negociação política. São agentes fundamentais no processo democrático representativo, pois estão respaldados no voto popular. De fato, somente com base neste critério - apoio eleitoral - é possível, no contexto das democracias de massa, falar de partidos como canais de expressão e representação de interesses, como um vínculo, ainda que frágil, entre a sociedade e o Estado. $\mathrm{Na}$ arena eleitoral, seu papel específico é o de competir pelo apoio dos eleitores a fim de conquistar posições de poder. É por meio desse mecanismo que a cadeia de representação política se forma nas democracias representativas, uma cadeia que vincula os cidadãos às arenas públicas de tomada de decisões. (2004, p.24-5)

Na realidade, esse vínculo do eleitor com as decisões por meio dos parlamentares é muito tênue, sendo difícil fazer o acompanhamento dos políticos no seu dia-a-dia, porque novas questões aparecem durante o mandato que não constavam das plataformas dos candidatos e, não menos importante, porque pode haver um descolamento do político de suas bases eleitorais, levando o político a tratar de outros interesses que não dizem respeito às fontes populares de seu mandato. Essas distorções introduzidas pela mediação da representação atenuam bastante o sentido original da ideia de democracia como "governo do povo", uma vez que ela se torna uma forma delegativa de poder, com mecanismos bastante limitados de acompanhamento da ação dos representantes. 


\section{Abordagens empíricas}

O contraste entre a teoria e a realidade é um desafio para a democracia, diz Bobbio (2000), referindo-se às promessas não cumpridas, como o fato, por exemplo, de nos estados democráticos contemporâneos não prevalecerem os indivíduos soberanos, mas os grupos, as grandes organizações, as associações, os sindicatos e os partidos, com sua relativa autonomia diante do governo central. Além disso, há uma persistência das oligarquias, o "poder invisível" constituído pelo crime organizado, serviços secretos etc., diante dos quais não há o controle do poder pelos cidadãos, mas o controle destes pelo poder.

Embora a parte procedimental da democracia deva efetivamente estabelecer as regras do jogo, uma vez que elas são os meios de viabilização das oportunidades de participação, há inúmeras formas de burlar essas regras, fazendo valer o poder econômico e social (as influências pessoais, grupais, estamentais, gremiais), que traem o ideal republicano, em benefício dos interesses de certos setores.

A essas circunstâncias, observadas por Bobbio, poderíamos acrescentar, ainda, a cena eleitoral, com as inúmeras possibilidades de ação da comunicação de massa, da retórica vazia, da demagogia e da própria mentira. Por último, mas sem fechar essa relação, a democracia é um sistema político vigente em sociedades com formações históricas muito diferentes, com estruturas contrastantes e, muitas vezes, injustas. Por isso, as sociedades dos países latino-americanos, por exemplo, se impacientam com as delongas e decepções da democracia, naquilo que o ex-presidente do TSE, Sepúlveda Pertence, chamou de "desalento democrático", refletido nas pesquisas empíricas que muitas vezes revelam uma adesão limitada ao ideal democrático.

Esses desvios e problemas, que para Sartori (1994) expressam a tensão entre ideal e fato na democracia, mostram como a discussão se trava entre o conceito normativo (o que a democracia deve ser) e o âmbito das realidades empíricas, nas quais podemos procurar nos regimes democráticos os desvios, os pesos proporcionais de entidades e de forças sociais e econômicas, de grupos organizados 
etc. traçando o perfil da democracia efetiva de que se está tratando, num determinado momento. As circunstâncias e conjunturas podem implicar avanços ou retrocessos nas conquistas democráticas, em relação ao conceito ideal.

Esses fatos mostram como é necessário não se limitar a análise às regras no estudo da democracia, mas analisá-la nos contextos de classes sociais, grupos de pressão, poder econômico, blocos, hegemonia etc., ou seja, realizar uma abordagem sociológica, que procure projetar a dimensão valorativa, normativa do conceito em sociedades históricas, analisando as configurações resultantes. Fábio Wanderley Reis, por exemplo, observa que em situações de grande desigualdade social, como o Brasil, diferentes indivíduos controlam porções muito desiguais de recursos na esfera econômica, levando a um desequilíbrio, tornando problemático o exercício efetivo dos direitos políticos e civis (2003).

A democracia tem sido invocada contemporaneamente na discussão de assuntos como condições de vida, justiça, lutas sociais. $\mathrm{O}$ investimento semântico do conceito é enorme e as expectativas que ele suscita empolgam as sociedades, em particular aquelas como as latino-americanas, a braços com graves problemas sociais. Se é verdade que ao longo do século XX aumentou o número de países democráticos, é preciso observar, sugere Rodrigues (2004), que em muitos casos trata-se de um conceito "mínimo" de democracia, estritamente político, acrescentando que se agregarmos a dimensão econômico-social à conceituação, é difícil pensar o século XX como o "século dos direitos sociais", como periodizou T. H. Marshal (1967).

A incapacidade das democracias dos países subdesenvolvidos de darem respostas rápidas e satisfatórias a essas premências expõe agudamente o problema da diferença entre as expectativas geradas pela redemocratização e a solução das questões coletivas. Sartori, no entanto, apesar de reconhecer a importância da democracia social e da democracia econômica, vê a democracia política como condição, instrumento indispensável de qualquer democracia ou meta democrática: para ele, "democracia" sem adjetivos é "democracia política", ou seja, trata-se de um conceito político antes de tudo (1994). 
O estudo das práticas políticas das sociedades contemporâneas revela também que a forma de concretização dos ideais democráticos apresenta certas peculiaridades, fugindo muitas vezes da norma ideal. O’Donnell (apud Castro Santos, 2001) propõe a expressão “democracia delegativa" para caracterizar os governos latino-americanos, diferenciando-a das democracias representativas ocidentais. As democracias delegativas implicam uma concepção cesarista do presidente, que atuaria como se estivesse investido de poderes para governar de acordo com sua vontade, limitado apenas pelas relações de poder e pela duração do mandato. A democracia delegativa combina eleições livres e competitivas com instituições políticas informais, como o clientelismo e o particularismo, pelo qual se confundem o público e o privado. Nesse regime, há limitada prestação de contas, pouca transparência dos processos de tomada de decisão, grande distância entre as normas e o funcionamento real das instituições, de modo que as concepções e práticas delegativas terminam por reviver as características autoritárias. Essa situação levou à ideia de uma gradação da democracia, definindo-se um limite mínimo de democracia, aceitando-se que, a partir daí, diferentes países, em razão das variações culturais, possam adotar outras práticas políticas (Król, 1996 apud Castro Santos, 2001).

Castro Santos (2001) escreve que a maioria dos autores que trata do processo de democratização utiliza o que ela chama de definição procedimental mínima de democracia, na linha de Dahl, que se refere a eleições livres, honestas, competitivas, a direitos civis e direitos políticos, mas muitos consideram esse critério insuficiente, advertindo contra a "falácia do eleitoralismo" e lembrando que eleições e partidos políticos não são suficientes para caracterizar uma autêntica democracia. Desse modo, acrescentam-se atributos ao procedimental mínimo, como a limitação das prerrogativas militares, a autodeterminação do sistema político, que deve agir de forma independente, previsão de que governantes eleitos não sofram restrições, não tenham suas decisões sujeitas ao veto de pessoas sem mandato eletivo, nem sejam afastados do cargo. 
A autora acrescenta que a análise do processo de consolidação democrática dos países em desenvolvimento deva contemplar o exercício da representação política e os padrões do processo de tomada de decisão. Citando Malloy (1977), ela propõe que democracia é um processo contínuo de formulação de políticas, no qual ressalta a presença dos principais grupos da sociedade civil, em especial sindicatos de trabalhadores e de empresários. Entende que ênfase exagerada vem sendo colocada na questão das eleições, partidos e direitos, esquecendo-se do acesso dos grupos organizados da sociedade civil às tomadas de decisão governamentais. Ela se refere ao controle social das burocracias, por meio do acesso ao processo de decisão dos grupos organizados da sociedade, o que não significa invocar a democracia participativa. Pode-se, por meio desse controle, verificar o caráter mais ou menos democrático dos regimes no período entre as eleições, explicitando os mecanismos de decisão, as formas de representação de interesses, o controle social das burocracias (Castro Santos, 2001).

\section{A democracia brasileira}

Escrevendo no final do processo de transição do regime militar para o poder civil no Brasil, Weffort (1984) considerava que a democracia brasileira sofreu um processo de instrumentalização. Segundo ele, o conservadorismo brasileiro legou-nos uma concepção autoritária de democracia e a tradição brasileira é marcada pela ambiguidade que permite aos governantes serem autoritários e democratas ao mesmo tempo, numa mistura de pragmatismo e cinismo, que toma a democracia apenas como instrumento para conquistar e manter o poder. Para ele, essa concepção vem das oligarquias da República Velha, que se diziam liberais, mas faziam do Estado uma espécie de apêndice dos latifúndios, convertendo seu liberalismo numa forma de privatismo. Um processo novo na transição brasileira, a partir de 1974, foi que se rompeu o realismo cínico da tradição, criando uma crença nova na democracia como valor geral. Essa nova perspectiva envolve não apenas os liberais de fachada a quem o autor se referira, 
mas também a esquerda, que participou da luta armada contra o regime militar:

Depois da derrota das armas, ficou claro para muitos que um dos modos, na verdade o mais efetivo, de se lutar contra uma ditadura estaria em organizar a democracia pela base, na sociedade. Tornouse, então, possível entender que a democracia é algo mais do que uma formalidade descartável e que as instituições civis e os movimentos sociais devem fazer valer a sua autonomia em face do Estado e dos partidos. (p.84)

O’Donnell, citado por Diniz (2001), 15 anos depois, enfatiza peculiaridades da formação histórica das democracias jovens, inclusive a brasileira, as quais geram uma fragilidade institucional que resiste às tentativas de mudança, como por exemplo a incompletude da cidadania, levando a lacunas nos direitos civis e sociais, o estreitamento dos espaços públicos, além de sérias limitações à efetividade da lei. Para Diniz, a prática de implantação de reformas do Estado sob regimes autoritários resultou na consolidação de um Executivo sobredimensionado, sem freios institucionais à sua capacidade de nomeações, em contraposição a um Legislativo enfraquecido em seus poderes. Nesse contexto, vigora um estilo tecnocrático de gestão econômica, com a valorização do saber técnico, tornando a administração pública um campo de competência de uma elite acima do questionamento da sociedade ou dos políticos. O resultado desse processo de formação do Estado brasileiro seria um déficit de accountability, ou seja, de procedimentos de cobrança e de prestação de contas, de controle, transparência e publicização dos atos do governo.

Na mesma direção, Castro Santos (2001) observa que no Brasil pós-autoritário, as tomadas de decisão ocorrem em duas arenas de poder: a representativa e a burocrática. A primeira é a da política, que se dá no Congresso, marcada pelo clientelismo, não se restringindo às regras constitucionais e regimentais, variando com o tipo de política em questão. Pode envolver um grande número de atores, como altos burocratas, o presidente e sua assessoria, os negociado- 
res do governo no Congresso, partidos e seus líderes, os líderes do governo no Congresso, os grupos de interesse afetados (empresários e suas entidades, sindicatos de trabalhadores, associações de aposentados etc.), governadores, prefeitos. Por sua vez, a chamada arena burocrática situa-se dentro do aparelho de Estado, sendo formada pelas agências burocráticas encarregadas de deliberar sobre a política pública em discussão. Para a autora, não ocorreram grandes mudanças nesta última arena a partir da democratização brasileira, a não ser pela incorporação de atores anteriormente excluídos, como representantes de trabalhadores e, mais recentemente, das Organizações da Sociedade Civil e de Interesse Público (OSCIPs). Ela considera que o processo dual de deliberação brasileiro apresenta uma forte afinidade com as chamadas formas híbridas de democracia, podendo ser transitório, em direção a um regime plenamente democrático.

Analisando o período de 18 anos, a partir de 1985, quando se dá o retorno do poder aos civis, Kinzo (2004) conclui que eleições e democracia estão consolidadas no Brasil, sendo que as eleições de 2002 constituíram um marco ao produzirem uma alternância tranquila de poder para o Partido dos Trabalhadores. No entanto, ela destaca que o quadro partidário brasileiro é marcado pela fragmentação, fragilidade partidária, baixa inteligibilidade da disputa eleitoral e elevada volatilidade eleitoral. Essas circunstâncias despertam preocupação sobre sua influência no processo democrático:

A fragmentação do sistema partidário não seria um problema para o funcionamento da democracia caso não afetasse a inteligibilidade do processo eleitoral, isto é, a capacidade de o sistema produzir opções claras para os eleitores, permitindo-lhes escolher com base em seu conhecimento sobre os partidos ou sua identidade com eles. O problema é que no Brasil a intensa fragmentação partidária está acompanhada por uma pequena inteligibilidade do processo eleitoral. Em geral, um sistema partidário fragmentado tende a ter partidos de contornos mais definidos, alicerçados em algum tipo de clivagem social, regional ou política, proporcionando aos eleitores 
opções mais estruturadas e diferenciadas na disputa eleitoral. Isso não é o que ocorre no caso brasileiro, dado que a maioria dos partidos, como organizações distintas, não possui contornos claramente definidos. (p.31-2)

A relativa indiferenciação partidária, argumenta a autora, facilita aos políticos trocarem de partido com frequência. A fragilidade dos partidos leva à formação de alianças partidárias, a coligações de partidos com orientações programáticas distintas, mesmo em eleições municipais e em eleições legislativas. Embora essa estratégia seja racional para partidos e políticos, que assim conseguem mais recursos eleitorais previstos na lei, para os eleitores torna mais difícil perceber claramente as alternativas eleitorais, em alianças que variam a cada eleição e em cada lugar. A eleição à presidência da República de um candidato de esquerda em 2002, apesar de sua importância política para a democracia, acabou levando a um governo de coalizão de dez partidos, maior que a do governo anterior, a uma intensa troca de partidos, em 2003, induzindo-a a questionar se o sistema partidário é realmente importante para a consolidação da democracia no Brasil (idem).

A democracia brasileira, eventualmente, experimenta, ainda, as deformações provocadas pelo poder econômico e pelas representações do processo político pelos meios, especialmente durante as campanhas eleitorais. Há ainda a crítica do descolamento da representação política dos eleitos em relação aos interesses dos representados, tornando mandatos um fim em si mesmo, em benefício dos representantes populares. A corrupção e a utilização do Estado como meio de enriquecimento pessoal que pode resultar dessa conduta, no Brasil, mais do que um problema moral ou jurídico tornou-se um problema econômico, dadas as suas proporções e seu impacto sobre os orçamentos.

Crítico radical dessa situação, Baquero (2001) invoca o conceito de desconsolidação democrática para referir-se ao Brasil. Segundo ele, muitos autores parecem considerar que a duração da democracia seja mais importante do que seus resultados em termos sociais, 
ignorando que essa durabilidade se dá às custas da perversão da legitimidade e da eficácia democráticas. O que ele chama de paradoxo da democracia brasileira é que quanto mais ela dura, mais é pervertida pelo neoliberalismo, que a faz funcionar a serviço de interesses privados, e pelo processo de globalização, por meio do qual o país é colocado numa situação de dependência neocolonial. Dessa forma, a durabilidade da democracia sobrepõe-se aos custos sociais de sua precariedade, representados pelo aumento da pobreza e da exclusão, enquanto os lucros são remetidos ao exterior, o que faz a democracia brasileira atuar cada vez mais antidemocraticamente e anti-institucionalmente. Nesse contexto, surge o neopopulismo, no qual líderes com carisma pessoal que contam com o apoio da população agem contra essa mesma população, instalando a austeridade econômica e ajustes que agravam as condições de vida do povo (Baquero, 2001).

Essas circunstâncias indicam as imperfeições de sua realização, a ausência da plenitude democrática, em contraste com as formulações normativas ou, ainda, ao salientarem os percalços da implantação da democracia em uma dada situação histórica concreta, marcada por ressonâncias arcaicas da formação histórica brasileira, mostram a importância dos estudos empíricos para avaliar as formas concretas assumidas pelo regime democrático e a necessidade de sua superação.

Já a discussão conceitual toma a democracia como o arcabouço institucional que dá espaço à participação política, à reivindicação social, à expressão cultural, no contexto da hegemonia capitalista, espaço que, historicamente, vem sendo alargado por meio dos movimentos sociais, pela extensão dos direitos da cidadania, por meio das reformas da legislação. Nesse sentido, as críticas à democracia "burguesa", ou democracia "eleitoral", democracia "formal", apesar de aparentarem corresponder a uma perspectiva dos trabalhadores, das maiorias, na verdade, agem contra eles, uma vez que a democracia, no contexto da hegemonia capitalista, representa um espaço de conflito institucionalizado entre as classes, a garantia de organização e reivindicação, um equilíbrio dinâmico de forças, que permite o alargamento das bases sociais dos governos. 


\section{Considerações finais do capítulo}

O "modelo" democrático que se esboça a partir desse percurso teórico aponta para um conjunto de instituições modeladas historicamente a partir do liberalismo e alargadas pelas lutas sociais da sociedade. Mais do que um regime de poder instituído por eleições, a democracia implica a vigência das liberdades e garantias individuais, a separação dos poderes, enfim um sistema de pesos e contrapesos que proteja os indivíduos de um Estado poderoso, mas que, ao mesmo tempo, permita que interesses majoritários não sejam prejudicados pela ação de indivíduos ou grupos. A democracia é também uma estrutura política capaz de viabilizar uma sociedade plural, com grupos diferentes, com interesses divergentes e às vezes antagônicos, que competem eleitoralmente mediante seus candidatos e partidos. Nessa democracia representativa, o poder de governar e de legislar é dos representantes, o que constitui um risco, uma vez que o povo só é consultado de tempos em tempos e os representantes podem, nesse interregno, esquecer a origem popular de seus mandatos e agir como se esses mandatos fossem seus. Por fim, essa estrutura política estabelece-se numa sociedade histórica, com suas divisões em classes, nas quais vigora a hegemonia capitalista, que constitui a contingência mais abrangente dos processos políticos democráticos. Eli Diniz, a esse respeito, observa que "as singularidades da evolução histórica têm um impacto na qualidade da democracia, em termos de suas duas dimensões básicas: os direitos de oposição e de participação política" (Diniz, 2001).

Nesse contexto, palavra matizada em muitas significações, com uma valência semântica que a vincula a uma pletora de aspirações coletivas, a democracia expressa primordialmente um princípio político, cuja implementação concreta se dá sob o regime republicano. A democracia parte do princípio de que os seres humanos são iguais e livres, não apenas para viver suas existências particulares - como estabelece o liberalismo -, mas lhes faculta a organização para lutar coletivamente pelo desenvolvimento social, pelos direitos, bem-estar e justiça. 
Sartori (1994) diz que a democracia existe como expressão de ideais e valores e o conceito gira em torno da sua tensão em relação aos fatos. Ela deve sua própria existência a seus ideais, que mantêm sempre diante de nós aquilo que a democracia deve ser, de tal modo que o conceito apresenta, além de uma função descritiva ou denotativa, também uma função normativa e persuasiva. Por isso, ele entende que mesmo uma teoria empírica da democracia tem de ser, num certo sentido, normativa.

Nessa linha de argumentação, se formos pensar nas sociedades brasileira e latino-americanas, por exemplo, com suas profundas disparidades sociais, o Estado precisa dar respostas a múltiplas demandas, como trabalho, moradia, educação, saúde, segurança, consideradas direitos fundamentais dos cidadãos, uma vez que são essas condições (sociais, econômicas e políticas) que viabilizam a efetiva participação no processo democrático. A democracia, como notou Bobbio, é um sistema dinâmico, cujos limites estão em permanente alargamento pela pressão dos cidadãos sobre o Estado. Daí o conceito de democracia expandido, que transcende os meros direitos políticos, pressionando as esferas do Estado para a instauração de uma sociedade mais justa.

Essa trajetória do conceito permite concluir concordando com Freitas (s. d.) que a democracia é muito mais um conceito em disputa do que universal, expressando diferentes perspectivas sobre o conflito entre interesses antagônicos na sociedade; as possibilidades de enfrentamento social; as chances de as classes subalternas irem além de uma representação formal e serem capazes de realizar a transformação social. Mesmo num contexto em que as classes se enfrentam de forma assimétrica, em que o espaço de ação das maiorias é limitado por uma série de bloqueios e em que a representação política é corrompida por diversas manobras, a democracia continua a ser a grande utopia contemporânea, expressando simultaneamente liberdades, representatividade e justiça social, ideais cuja implementação, por vezes, os leva a conflitar entre si.

Democracia tornou-se um conceito negado por diversos autores, como Dahl (1997), que propôs o termo poliarquia, ou Castro Santos, 
criticando a ingenuidade de muitos que a estudam e mesmo o caráter peculiar das democracias ocidentais, nem sempre viáveis fora dos países capitalistas centrais. Mas esses autores, no entanto, não se afastaram do conceito, nem o substituíram. Quando se fala, hoje, em democracia, inclusive nas esferas do cotidiano, da universidade, da empresa, pensa-se não apenas na organização político-institucional do Estado, mas no caráter de participação ou representatividade equilibrada no processo decisório, na transparência deste último, que deverá redundar em deliberações mais justas. A discussão sobre democracia, num sentido genérico, rompe com o âmbito puramente institucional para outros espaços de decisão coletivos, nos quais não perde seu caráter político em sentido lato. Democracia seria, então, mais do que simplesmente eleger representantes, mas diria respeito às práticas deliberativas, uma luta contra os privilégios e dominações (Deetz, 1992).

\section{Referências bibliográficas}

BAQUERO, M. Cultura política participativa e desconsolidação democrática, reflexões sobre o Brasil contemporâneo. São Paulo Perspec., v.15, n.4, São Paulo, out./dez. 2001.

BOBBIO, N. O futuro da democracia. Rio de Janeiro: Paz e Terra, 2000. Castro Santos, M. H. Que democracia? Uma visão conceitual desde a perspectiva dos países em desenvolvimento. Dados, v.44, n.4. Rio de Janeiro, 2001.

CHEIBUB, J. A. \& PRZEWORSKI, A. Democracia, eleições e responsabilidade política. Revista Brasileira de Ciências Sociais, v.12, n.35, p.49-61, S. Paulo, out. 1997.

COSTA, S. Democracia cosmopolita: déficits conceituais e equívocos políticos. Revista Brasileira de Ciências Sociais. v.18, n.53, São Paulo, out. 2003.

DAHL, R. Poliarquia: participação e oposição. São Paulo: Edusp, 1997.

DAHAL, R. A. Sobre a democracia. Brasília: Ed. da Universidade de Brasília, 2001.

DEETZ, S. A. Democracy in an age of corporate colonization, developments in communication and the politics of everyday life. Albany: State University of New York Press, 1997. 
DINIZ, E. Globalização, reforma do estado e teoria democrática contemporânea. São Paulo em Perspectiva, v.15, n.4, S. Paulo, out./dez.2001

ELSTER, J. Peças e engrenagens das Ciências Sociais. Rio de Janeiro: Relume-Dumará, 1994.

The Market and the Forum: three varieties of political theory. In: BOHMAN, J. \& REGH, W. (Eds.). Deliberative democracy: essays on reason and politics. Cambridge: MIT, 1997.

A possibilidade da política racional. Revista Brasileira de Ciências Sociais. v.14, n.39, São Paulo, p.14-40, fev. 1999.

FREITAS, F. F. B. Democracia: um conceito em disputa. Disponível em: http://www.espdh.hpg.com.br/texto46.pdf. Acesso em 1\%/02/06.

GRAEBER, D. O carnaval está em marcha. Folha de S. Paulo, Mais! 14 de agosto de 2005, p.5-6.

KINZO, M. D. Partidos, eleições e democracia no Brasil pós-1985. Revista Brasileira de Ciências Sociais, v.19, n.54, São Paulo, fev. 2004.

KRÓL, M. Where East Meets West. In: L. Diamond e M. F. Plattner (Eds.), The global resurgence of democracy. Baltimore/Londres: The Johns Hopkins University Press, 1996.

MAIA, R. C. M. A deliberação nos media: desafios conceituais e apontamentos metodológicos. In: ENCONTRO ANUAL DA ASSOCIAÇÃO NACIONAL DE PÓS-GRADUAÇÃO EM CIÊNCIAS SOCIAIS - ANPOCS, 31, Caxambu, 2007. Anais... São Paulo: ANPOCS, 2007. 1 CD-ROM.

MALLOY, J. (ed.). Authoritarianism and corporatism in Latin America. Pittsburgh: The University of Pittsburgh Press, 1977.

MARSHALL, T. H. Cidadania, classe social e status. Rio de Janeiro: Zahar, 1967.

MIGUEL, L. F. A democracia domesticada: bases antidemocráticas do pensamento democrático. DADOS - Revista de Ciências Sociais, Rio de Janeiro, v.45, n.3, 2002.

Representação política em 3-D: elementos para uma teoria ampliada da representação política. Revista Brasileira de Ciências Sociais. v.18 n.51. São Paulo, fev. 2003.

O’DONNELL, G. Teoria democrática e política comparada. Dados, v.42, n.4, Rio de Janeiro. 1999.

REIS, F. W. Democracia, igualdade e identidade. In: PERISSINOTTO, R. M. \& FUKS, M. (Orgs.). Democracia : teoria e prática. Rio de Janeiro: Relume-Dumará, 2003. 
REIS, F. W., CASTRO, M. M. M. De democracia, civismo e cinismo, um estudo empírico sobre normas e racionalidade. Revista Brasileira de Ciências Sociais. v.16, n.45. São Paulo fev. 2001.

RODRIGUES, A. T. A democracia como invenção política. Rev. Sociol. Polít., n.22. Curitiba, jun. 2004.

SALES, C. V. As máscaras da democracia: notas sobre a teoria democrática contemporânea à luz dos eixos dahlsianos. Rev. Sociol. Polit., n.24, Curitiba, jun.2005.

SARTORI, G. A teoria da democracia revisitada. São Paulo : Ática, 1994. SCHRAMM, L. D. Dilemas democráticos e midiáticos contemporâneos. Apontamentos epistemológicos e normativos para uma compreensão das relações entre mídiaa e democracia. In: ENCONTRO ANUAL DA ASSOCIAÇÃO NACIONAL DE PÓS-GRADUAÇÃO EM CIÊNCIAS SOCIAIS - ANPOCS, 31., Caxambu, 2007. Anais... São Paulo: ANPOCS, 2007. 1 CD-ROM.

SCHUMPETER, J. A. Capitalismo, socialismo e democracia. Rio de Janeiro: J. Zahar, 1984. 



\section{5 \\ JORNALISMO E DEMOCRACIA, ALÉM DAS ANTINOMIAS}

\section{Introdução}

Este capítulo examina as abordagens sobre o papel do jornalismo no regime democrático. Preliminarmente apresenta diferentes modelos de democracia e os papéis que os meios noticiosos deveriam desempenhar para atender às exigências de cada um deles. Em seguida, contrasta duas orientações polarizadas sobre as relações entre o jornalismo e a democracia. De um lado, situa os autores que se inclinam a ver o jornalismo como essencial para a democracia e, de outro, os analistas e intérpretes críticos que, pelo contrário, veem a atividade das empresas jornalísticas na política com um conteúdo enviesado, o que as leva a ter uma atuação tendenciosa na sociedade, favorecendo posições, pessoas e grupos, construindo representações distorcidas da realidade, o que converteria o jornalismo num instrumento de poder simbólico nas mãos de uma minoria. Ao final, desenvolve uma argumentação visando enfrentar o impasse teórico por meio do conceito de hegemonia. Essa abordagem reconhece a existência de classes hegemônicas em sociedades democráticas, com influência sobre a mídia e suas representações, mas, ao mesmo tempo, propõe que exista um espaço para visões alternativas e críticas, numa perspectiva histórica. 


\section{Modelos de democracia e comunicação}

A discussão específica sobre as relações entre a comunicação e a democracia constitui um aspecto peculiar no campo da pesquisa em comunicação política. Nos regimes autoritários também há comunicação política, mas esta se realiza como propaganda, ortodoxia, centralismo, ausência de debate ou de pluralidade das vozes. $\mathrm{Na}$ democracia, pelo contrário, há liberdade de expressão, uma pluralidade de vozes, o confronto ideológico, o governo precisa renovar o discurso, responder às críticas da oposição, veiculadas pelos meios de comunicação (Ansart, 1978). Tem-se nesse caso uma questão mais complexa que a relação da comunicação com a política, que implica necessariamente aspectos doutrinários, critérios normativos e valores ligados ao progresso social.

Discutir a importância da liberdade de imprensa para a democracia exige que se tenha uma teoria dessa forma de governo, diz Baker (2001). Como não há um consenso sobre o conceito de democracia, ele apresenta quatro tipos ou modelos ideais, sendo que cada formulação de democracia apresentaria perspectivas distintas do papel dos meios. As abordagens foram reunidas em quatro grupos: a) as teorias elitistas de democracia; b) a concepção liberal-pluralista ou de grupo de interesse; c) a concepção republicana, e d) a "democracia complexa”, denominação que Baker dá à sua visão mais empírica e realista.

\section{A perspectiva elitista de democracia}

A perspectiva elitista prioriza a necessidade dos governos de tratar de questões tecnicamente complexas, exigindo uma ordem normativa flexível, útil e efetiva para resolver disputas. Que tipo de governo pode desempenhar melhor esse papel? Para a visão elitista, a democracia é a resposta, mas uma democracia vista de uma maneira limitada, como um modo de solucionar os problemas da sociedade complexa, sem se apoiar na força, baseando-se na competição. As eleições seriam uma forma de circulação das elites, criando incentivos para 
um desempenho eficaz dos governantes, oferecendo assim o melhor, senão o único, mecanismo para evitar a tirania e corrupção aberta.

Para desempenhar essa missão, a democracia precisa de uma imprensa livre, que eventualmente exponha a corrupção das elites, exercendo dessa maneira a função de cão de guarda, ou de vigilância, papel mais importante da imprensa para a democracia. Além disso, a imprensa precisaria reforçar o sentido geral de legitimidade do sistema, examinar a adequação do caráter e comportamento das figuras públicas, prover informação objetiva sobre os grandes problemas da sociedade, fornecendo às elites informação útil e revelando sua possível incompetência na condução dos problemas. A exposição da incompetência à sociedade seria útil para promover a rotação das elites.

\section{Democracia dos grupos de interesse}

Enquanto a visão elitista valoriza a democracia com a finalidade de manter o sentido de legitimidade do governo, a perspectiva denominada por Baker como pluralismo liberal parte do pressuposto de que o povo tem direito a governar, enaltecendo a vontade popular em vez das virtudes de elites que governam. O pluralismo liberal reconhece que cada indivíduo ou grupo tem seu próprio interesse, seus próprios conceitos, de modo que trata os temas políticos essencialmente em termos distributivos, vendo a democracia como o mecanismo mais capacitado a ponderar todos os interesses. A mobilização política dos grupos dá a eles poder de barganha, sendo que a participação política e eleitoral protege os direitos e interesses e constitui o meio pelo qual cada grupo será considerado, mais ou menos na proporção do seu tamanho e da intensidade de seus interesses. De acordo com a teoria liberal-pluralista, a criação de compromissos justos ou negociações entre grupos deveria guiar a construção de instituições.

Os liberais pluralistas observam que um aspecto revelador de muitas teorias de elite é o seu silêncio sobre certas questões, como classe, gênero, cor ou etnicidade, religião. Pelo contrário, o plura- 
lismo liberal tem sempre em vista essas clivagens, o conflito entre valores, interesses e visões de mundo.

Para essa concepção de democracia, a imprensa deveria oferecer informação, indicando quais os interesses de indivíduos e de grupos que estão em jogo. Os meios deveriam ajudar a mobilizar as pessoas a participarem e a promoverem seus argumentos. Em terceiro lugar, os meios deveriam tornar as autoridades conscientes do conteúdo e força das demandas populares. Para as duas primeiras tarefas, os meios comuns, que servem a toda a sociedade, não seriam suficientes, pois os grupos de interesses deveriam ter seus próprios meios, identificados com suas questões. Os pluralistas apóiam-se em meios militantes e mobilizadores, devendo ser, por conseguinte, opostos aos monopólios mediáticos. Essa visão baseia-se na segmentação da audiência, defendendo a existência de meios focalizados e controlados por grupos de pressão.

\section{Democracia republicana}

Os críticos do liberal pluralismo alegam que seu realismo insensível na verdade não corresponde à realidade, devido a dois atributos da maioria das pessoas, essenciais à democracia. Primeiro, o fato de que somos seres sociais, zelosos dos outros e não egoístas e atomizados, sendo motivados por concepções de bem comum e pela preocupação com o bem-estar dos outros. Em segundo lugar, os interesses das pessoas não resultam diretamente de sua identidade grupal, mas de autorreflexão, discurso, em interação com outros.

A perspectiva republicana considera esses dois atributos, dizendo que as pessoas são orientadas para o "bem comum", havendo por parte delas uma preocupação com a justiça ou com um mundo melhor para todos. Para essa concepção, democracia e política dizem respeito ao bem público e não apenas ao privado. Os interesses estreitos dos grupos não poderiam, dessa maneira, ser aceitos como normativos, mas deveriam ser vistos como um problema que uma democracia ideal precisaria enfrentar. Na visão republicana, a política diz respeito 
à discussão, à formulação de um compromisso com finalidades comuns, e a democracia é vista como uma forma de a sociedade buscar o equilíbrio na ação conjunta em busca de objetivos partilhados.

A imprensa, para a democracia republicana, precisa apresentar dois elementos essenciais: a) deve ser racionalmente discursiva e reflexiva e não meramente informativa e b) ser inclusiva, civil, objetiva, equilibrada e compreensiva.

\section{Democracia complexa}

Essa perspectiva reconhece que as duas anteriores - pluralista liberal e republicana - têm pontos consideráveis. Por um lado, entende que a vida social não seria possível sem uma perspectiva de bem comum, mas, da mesma forma, sabe que muito da política envolve interesses em conflito ou até mesmo desacordo sobre a própria concepção sobre o que vem a ser o bem comum. Apresentada como uma teoria mais realista, assume que a escolha não precisa ser entre o pluralismo liberal e o republicanismo, mas uma visão combinada de ambos, assumindo a legitimidade da barganha entre grupos sobre concepções do bem, a necessidade de um desenvolvimento discursivo das concepções do bem comum e, afinal, uma sociedade pluralista apresenta grupos com concepções diferentes do bem, que em parte se sobrepõem e em parte estão em tensão.

O que o exercício proposto por Baker deixa entrever é que, na perspectiva da democracia complexa, as exigências democráticas, oriundas da sociedade, são, em seguida, controladas pelo princípio republicano do "bem comum". Essa concepção é discutida por Renato Janine Ribeiro (2002), para quem é cada vez mais difícil manter a noção de povo - demos - o que traz a necessidade de rediscutir o conceito de democracia apropriado para a época contemporânea. Ele acredita que haja concretamente frações do povo com demandas (desejos, na sua terminologia) diferentes, cabendo à república refrear essas demandas, em nome de um bem comum, que é preciso preservar. A democracia seria um regime movido pelo desejo, enquanto a 
república visa conter esse desejo, sendo o regime da (força de) vontade. Apesar disso, considera difícil pensar a democracia isoladamente da república e vice-versa.

Não há política digna desse nome, hoje, que não seja republicana e democrática. O problema é que as duas vertentes não se conciliam facilmente. Se tendermos à democracia, o desejo de igualdade, e o desejo em geral, poderá inviabilizar o investimento de longo prazo, o respeito ao outro, a contenção. A própria conversão do desejo em direito é um elemento republicano. Contudo, se enfatizarmos a república, poderá ser que o respeito à coisa pública se torne fim em si, e deixe de lado a igualdade: teremos uma república de juízes (ou promotores), sem o aquecimento que está na democracia. (Ribeiro, 2001, p.77)

Dessa forma, parece bastante apropriado tomar a democracia complexa como o modelo que melhor corresponde à realidade empírica.

A imprensa idealizada pela democracia complexa precisaria desempenhar funções conflitantes destacadas pelas teorias liberal pluralista e republicana e mais ainda, diz Baker. A democracia complexa demanda tanto uma imprensa socialmente abrangente desejada pela teoria republicana quanto uma imprensa militante, segmentada, exigida pela teoria pluralista, apta a representar a pluralidade da sociedade. Numa projeção futura, provavelmente diferentes meios de comunicação seriam necessários para desempenhar essas funções divergentes, podendo, inclusive diferir em sua organização interna e sua base econômica.

\section{Visões polarizadas}

Se concordarmos com a preferência de Baker pela maior abrangência conceitual e política do modelo de "democracia complexa", podemos indagar: até que ponto os meios noticiosos de grande ex- 
pressão atendem, nas sociedades contemporâneas, àqueles requisitos enumerados pelo autor como necessários à busca do bem comum?

Essa questão geralmente abre uma controvérsia nos trabalhos investigativos empíricos sobre as relações entre o jornalismo e a democracia, os quais podem ser agrupados, grosso modo, a partir de duas orientações polarizadas. De um lado, há os autores liberais, que se inclinam a ver o jornalismo como decisivo para a democracia, caracterizando-o como "cão de guarda" dos cidadãos, garantidor da lisura no trato do governo, "os olhos da nação", o "quarto poder" e, por conseguinte, o verdadeiro fiel da democracia e condição para o exercício da cidadania. De outro lado, encontramos os analistas e intérpretes críticos que, pelo contrário, veem a atividade das empresas jornalísticas na política com um conteúdo de classe, o que as leva a ter uma atuação tendenciosa na sociedade, favorecendo posições, pessoas e grupos, construindo representações distorcidas da realidade, o que as torna um instrumento de poder simbólico nas mãos de uma minoria (Curran, 2006). Vamos preliminarmente apresentar os argumentos mais frequentes dessas duas visões, bem como as reflexões suscitadas por elas para, ao final, desenvolver algumas ideias tentando enfrentar os impasses.

\section{Jornalismo como instrumento da democracia}

O verbete Democracy and the media, redigido por McGee para a Encyclopedia of communication and information (Schement, 2002), declara que nas sociedades modernas é impossível falar de democracia sem levar em conta o papel desempenhado pelos meios, especialmente depois do surgimento dos meios eletrônicos, que ampliaram as conexões entre democracia, campanhas políticas, opinião pública e jornalismo. Na mesma direção caminha o argumento de McQuail (2002), para quem a comunicação de massa tornou-se um elemento essencial do processo democrático, ao instaurar uma arena e canal para o amplo debate, tornando candidatos conhecidos, veiculando 
opiniões e informações diversas. Trata-se de uma opinião bem estabelecida, principalmente no campo acadêmico anglo-saxônico, com base na tradição dos pensadores liberais ingleses e norte-americanos.

O cânone liberal baseia-se em três conceitos essenciais: a mídia como "cão de guarda" do público, como representação pública (o quarto poder) e como fonte de informação pública (Curran, 1996). No que diz respeito ao primeiro, o do cão de guarda, afirma-se que só baseando os meios no mercado livre é possível assegurar sua completa independência em relação ao governo, função que seria gravemente afetada por regulações oficiais, que enfraqueceriam a capacidade de investigar e de criticar livremente as autoridades. O papel de cão de guarda remete àquela função da comunicação que Merton (in Costa Lima, 2000) denominou de "execução das normas sociais", ou seja, tornar inaceitável publicamente aquilo que é tolerado privadamente. A denúncia faz com que os desvios dos governantes sejam combatidos e punidos com rigor. Nesse sentido, a mídia atua como aliada dos cidadãos, que não detêm mandatos nem poder, diante dos desmandos da autoridade.

A ideia do quarto poder coloca em pauta a questão da representação política pela mídia. Originalmente Fourth state (o quarto Estado), a expressão foi cunhada por Edmund Burke para referir-se ao poder político da imprensa na Inglaterra do século XVIII, ao lado dos três outros "estados": os Lordes, a Igreja e os Comuns. Em português, usa-se a expressão quarto poder em analogia aos três poderes da República (Legislativo, Executivo e Judiciário). Seus defensores, no século XIX, argumentavam que os jornais são "eleitos" diariamente pelos leitores, sendo uma instituição representativa que deveria ser aceita como parceira no processo de governança, como um ramo do governo com poder na confecção das leis. No século $\mathrm{XX}$, o argumento foi atenuado e convertido em termos do conceito de soberania do consumidor: a imprensa não é determinada senão pelos seus leitores, de modo que, num sistema de mercado, procura dar ao leitor o que ele quer, assegurando que os jornais reflitam as visões e valores dos seus compradores. O consumidor figura, nessa abordagem, como o controlador final da imprensa, transformando 
os jornais em representantes do público, mais do que os interesses políticos organizados. Durante a Guerra Fria, a imprensa soviética aparecia como o contraste monstruoso a esse modelo, por ter absorvido totalmente a imprensa no âmbito do Estado, abolindo dessa forma qualquer ponto de vista crítico independente (Curran, 1996).

Albuquerque (1999) argumenta que a ideia de quarto poder tem, no Brasil, um significado bem diferente, peculiar, implicando um papel político mais ativo do jornalismo que o aproxima de um modelo caracteristicamente brasileiro de "poder moderador". Isso levaria imprensa brasileira a adotar relações com o poder Executivo que se poderiam qualificar ora como "governismo", ora como "oposicionismo", de modo a atender ao seu compromisso com a defesa da democracia e da ordem pública. Em resumo, o jornalismo brasileiro reinterpretaria o modelo de jornalismo independente numa chave própria, influenciada pela nossa cultura política. Nos termos de Albuquerque, no Brasil, a imprensa reivindicaria o papel de árbitro das disputas entre os poderes constituídos, decidindo sempre em favor do "bem comum".

O terceiro ponto frisado por Curran (1996) refere-se ao papel informativo da mídia, promovendo a racionalidade pública e a autodeterminação coletiva, o que só poderia ser realizado adequadamente num mercado livre, no qual qualquer um está autorizado a publicar suas opiniões e um amplo espectro de informações de fontes mutuamente adversárias. Só assim os cidadãos poderiam ser informados sobre uma variedade de pontos de vista, por meio de canais de comunicação abertos entre o governo e os governados, promovendo uma zona neutra de formação da opinião pública, central para o exercício da soberania popular. Essa ideia encontra respaldo nos estudos sociológicos que em vista da vasta gama de assuntos aos quais não temos acesso pessoalmente, colocam o conhecimento social como dependente das fontes de informação.

Nessa perspectiva positiva, além dos argumentos dos autores liberais, há outras vozes, como Wolton (1995), que toma como referência o conceito de esfera pública. Para o autor, não existe uma antinomia entre comunicação e democracia de massa, antes, pelo 
contrário, a comunicação é uma condição estrutural do funcionamento da democracia. Em As contradições do espaço público mediatizado (1995), ele diz que a democracia pressupõe a existência de um espaço público no qual sejam debatidos os grandes problemas do momento. A democracia de massa que temos hoje implica um maior número de atores, exprimindo-se sobre um número maior de assuntos. Isso modificou o espaço público, no sentido de um alargamento resultante da democratização e do papel cada vez maior representado pelos meios de comunicação. Por isso, o espaço público contemporâneo é um espaço público mediatizado, o que quer dizer que ele é indissociável do papel dos meios de comunicação.

No século XVIII, o espaço público surge restrito, ligado a uma elite iluminada, pequena e homogênea do ponto de vista social e cultural, que debatia entre si, informada por uma imprensa e pela edição livreira. Esse modelo nada tem a ver com o espaço público de uma democracia de massa com sufrágio universal igualitário; alargamento constante do campo político; institucionalização das grandes funções sociais ligadas à educação e à saúde; atores de origem social e cultural diferenciada; conflitos mais numerosos; presença dos meios de comunicação de massa; pesquisas de opinião pública.

O novo espaço público existe numa sociedade aberta, urbanizada, com forte valorização do indivíduo. Mas, ao mesmo tempo, esse espaço caracteriza-se também pela organização de massa, em termos de trabalho e de consumo, dos tempos livres e de educação.

A contradição principal da nossa sociedade está exatamente em administrar essas dimensões opostas, que Wolton chama de "sociedade individualista de massa". De um lado essa sociedade implica a prioridade concedida a tudo aquilo que facilita a expressão, a identidade e a libertação do indivíduo, e de outro é uma sociedade que nos planos econômico, político e cultural baseia-se no grande número. Essa antinomia pressupõe a existência de um espaço público alargado, mediatizado, o único no qual se pode administrar essa característica contraditória das sociedades atuais. Nesse novo espaço público, a imprensa e os meios audiovisuais desempenham um papel considerável, em termos de informação e de comunicação. 
Além disso, esse espaço público é caracterizado pelas pesquisas de opinião que constroem permanentemente uma representação da opinião pública. Assim, as informações sobre os acontecimentos fornecidas pelos meios e as pesquisas sobre o estado da opinião de outro são condições de funcionamento do espaço público alargado da democracia de massa.

Apesar de seu otimismo, Wolton reconhece a existência de contradições na implementação desse espaço público. Para ele, a comunicação é condição funcional e normativa do espaço público e da democracia de massa, mas não pode, por si própria, garantir a qualidade do funcionamento desse espaço público democrático. Isso porque há valores políticos diferentes dos valores comunicacionais. Além disso, a comunicação mediática aprofundou a personalização que já existia na política.

Outra contradição vislumbrada por Wolton é a que ele denomina identificação comunicação-ação. Em política, a ação é inseparável da comunicação, sobretudo em uma democracia, na qual os políticos devem satisfações de suas ações. Mas se a política se define pela tomada de decisão, pelo exercício do poder, há hoje um crescimento da comunicação em relação à ação, um apagamento da fronteira entre comunicar e agir.

Por último, ele se refere à falsa transparência, ao sentimento de que os problemas importantes de uma sociedade são visíveis, sendo sempre levados ao conhecimento de todos (pelos meios de comunicação e pelas pesquisas de opinião). É uma falsa visibilidade, que resulta num sentimento de relativa segurança. É uma ilusão de um conhecimento dos fatos. É preciso manter diferentes representações da sociedade para evitar uma falsa homogeneidade, uma falsa transparência.

Para solucionar essas contradições da comunicação na democracia contemporânea, ele defende que o crescimento paralelo da comunicação e da política torna necessária a permanência de um antagonismo entre os valores de cada uma das áreas. Antigamente, a comunicação e a política encontravam-se normativamente ligadas 
ao modelo democrático. A vitória do modelo democrático obriga a dissociá-las. Para evitar os desvios para o espaço público mediatizado é preciso recriar a tensão entre valores complementares, mas estruturalmente contraditórios: os da comunicação e os da política. No entanto, o autor não sugere um caminho para a manutenção dessa independência entre os valores da política e da comunicação. Se a própria política precisa dos meios para legitimar-se continuamente, aumenta a dependência da política em relação à comunicação.

Wilson Gomes (1997) também examinou a problemática relação entre os meios e a organização democrática da sociedade, fazendo, para isso, uso do conceito de esfera pública, conforme foi proposto por Habermas, visando examinar seu sentido, alcance e validade na discussão da situação da comunicação e política. Para Gomes, a esfera pública indica "o âmbito da vida social em que se realiza a discussão permanente entre pessoas privadas reunidas num público".

Mas a esfera pública não existe mais dessa forma e é discutível mesmo que tenha existido no passado. As mudanças pelas quais passou a sociedade contemporânea solaparam suas bases, criando a ilusão de que ela teria se mantido, quando, na verdade há muito deixou de existir, mantendo apenas a aparência de uma "pseudoesfera pública, encenada, fictícia, cuja característica maior parece consistir em ser dominada pela comunicação e cultura de massas" (idem, p.7) Apesar disso, o conceito de esfera pública continua a fazer sentido porque "se está descrevendo uma instituição que é nada mais nada menos que o coração da democracia moderna" (idem, p.26). O problema é que esse conceito não deve ser tomado descritivamente, mas sim normativamente:

Isso significa que só aparentemente ele descreve o que se passa com os fenômenos; na verdade ele diz como os fenômenos seriam, se fossem como deveriam ser. Um conceito normativo não é construído a partir dos fenômenos e para deles dar conta, mas a partir daquilo que se considera como sendo a essência dos fenômenos e para justamente normatizar os fenômenos reais e concretos, como critério para a sua avaliação. (idem, ibidem) 
Gomes defende, no entanto, a "possibilidade de convivência entre uma esfera argumentativa, coerente, racional e aberta e uma cena pública sedutora, voltada para o entretenimento, frívola e espetacular" (1998). Essa dicotomia resolver-se-ia distinguindo a esfera de visibilidade pública da esfera da discussão pública, sobre cuja pauta os meios têm influência. Por isso, ele vê a existência de uma esfera pública no interior da própria cena pública mediática, caracterizada pelos debates que ela, ainda que não sistematicamente, propicia, por meio da realização de entrevistas, discussões etc.

\section{Jornalismo como viés da democracia}

Na direção contrária, há autores que veem nos meios, na forma como se apresentam na sociedade capitalista, um empecilho à plenitude da democracia, entendida como governo pela maioria. Uma demolição sistemática do legado de visões da tradição liberal sobre o papel democrático dos meios foi desenvolvida por Curran (1996), para quem essa tradição tem pouco a ver com a realidade contemporânea, apesar de seus pontos de vista virem sendo repetidos ao longo do tempo. Embora considere a supervisão crítica do governo como um aspecto importante da ação da mídia, argumenta que se trata de uma concepção simplista da sociedade, na qual o conflito principal é visto entre o indivíduo e o Estado, ignorando a opressão exercida por outras estruturas, como a economia, por exemplo. Os meios têm, documentadamente, deixado de investigar criticamente as atividades dos conglomerados aos quais pertencem, e não agem como cães de guarda independentes servindo o interesse público, mas sim como organizações que usam sua força para promover seus próprios objetivos particulares. Outros autores veem a emergência de um complexo informacional-cultural com laços com o governo, que dá apoio ao capital e ao conservadorismo, sendo, em vez de uma fonte popular de controle do governo, meramente um meio pelo qual as forças dominantes buscam exercer influência informal sobre o Estado. A crítica real seria aquela proveniente da militância da esquerda, 
mas tanto os governos como a imprensa tendem a ser conservadores. Embora possa haver conflitos entre jornais e governos, a tendência é a uma lealdade patriótica daqueles a estes, em casos de crise. Por último, não caberia adequadamente à imprensa, no sistema de mercado, o papel de cão de guarda, porque seu conteúdo é constituído principalmente pelo entretenimento.

Ao examinar a ideia da mídia como representação pública do consumidor (o quarto poder), Curran diz tratar-se de uma mitologia, pois o domínio dos meios por oligopólios restringiu a diversidade, a escolha dos meios de comunicação pela audiência e o controle público, reduzindo a entrada de outras empresas no mercado, de modo a criar uma zona de influência na qual as forças econômicas dominantes têm já uma posição privilegiada. As atuais estruturas de mercado, assim, ao contrário do que propalam os liberais, em vez de promoverem a diversidade, constrangem e impõem limites à diversidade. Ele argumenta que o conceito de controle soberano do consumidor ignora o papel central da publicidade comercial no financiamento dos meios, bem como o espectro de influências que dão conteúdo à mídia e, por fim, a resistência das organizações informativas às pressões populares.

Ao tratar dos meios como fonte de informação pública, o autor comenta que a própria existência de um mercado de mídia constitui um empecilho ao jornalismo. Transformada em mercadoria, a informação acaba sendo simplificada, condensada, personalizada, descontextualizada, dando ênfase à ação em vez de ao processo, à visualização em vez de à abstração, ao estereótipo em vez de à complexidade humana.

Corroborando essa visão, McChesney (1999) observa que o jornalismo nos Estados Unidos baseia-se em fontes oficiais, evitando, por outro lado, assuntos públicos de longo prazo, minimizando a oferta do contexto histórico e ideológico necessário aos leitores. Os jornalistas internalizam a noção de que os negócios é que realmente conduzem a sociedade, de modo que promovem uma ampla cobertura dos mesmos, achando natural que haja pouca atenção ao mundo 
do trabalho. Dessa maneira, estão longe de ser politicamente neutros ou “objetivos". Para esse autor, as noções tradicionais de separação de interesses editoriais e comerciais estão se enfraquecendo à medida que anunciantes desempenham um papel crescente na determinação dos conteúdos (McChesney, 1997).

No Brasil, um dos autores pioneiros na vertente dos estudos acadêmicos dessa temática, Marcondes Filho (1989), também desenvolve uma crítica categórica do jornalismo produzido nos marcos do capitalismo. Para ele, o jornalismo, via de regra, atua com grandes forças econômicas e sociais, representando conglomerados econômicos ou grupos políticos interessados em dar foro de objetividade às suas ideias. Alexis de Tocqueville considerava a imprensa como garantia da liberdade individual na sociedade democrática, mas essa perspectiva tornou-se anacrônica com a tendência à concentração da imprensa. Em meados do século XX, a imprensa torna-se empresa com fins lucrativos, sem perder seu caráter político. Para ele, o jornalismo moderno é seleção, ordenação, atribuição ou negação de importância a fatos, os quais passam a funcionar como se fossem o espelho do mundo, enquanto, na verdade, se trata de uma forma mascarada de luta pelo poder (Marcondes Filho, 1989).

Miguel (2001) observa que os meios são hoje o principal instrumento de difusão das visões de mundo e dos projetos políticos, sendo que neles se encontram as representações do mundo social, ligadas aos diversos grupos de interesse da sociedade. Mas há um viés nessa representação: os meios reproduzem mal a diversidade social, o que acarreta resultados negativos para o exercício da democracia:

Tal quadro deixa claro que os meios de comunicação, na forma em que existem hoje, dificilmente darão espaço para a expressão ou a constituição de interesses que ameacem as estruturas básicas do capitalismo. (...) De fato, o desequilíbrio de recursos que o capitalismo produz na esfera econômica transborda sem cessar para a esfera política, comprometendo a igualdade que é requisito para o exercício da democracia (...) e a propriedade da mídia pode ser encarada como uma manifestação deste fato mais geral... (p.5-6) 
A influência dos meios sobre o campo político dá-se na formação do capital político, de modo que a visibilidade na mídia é essencial. Mas a influência dos meios também é visível na formação da agenda dos leitores ou espectadores, ou seja, a pauta das questões relevantes, na capacidade de formular preocupações públicas. Além da agenda, os meios têm a capacidade de enquadrar os acontecimentos, por meio de esquemas que privilegiam certa interpretação dos acontecimentos.

O autor argumenta que a ação dos meios também se expressa na própria concepção do campo da política que, via de regra, é restrito às instituições políticas, a questões como o parlamento, os poderes, eleições e partidos, deixando num segundo plano questões como os movimentos populares, as demandas de minorias ou de mulheres, lutas ambientalistas. A mídia adapta-se ao recorte dominante que é formulado pelo próprio campo político. Assim, o noticiário jornalístico, focalizando a disputa por cargos e estratégias partidárias, contribuiria para fixar o campo da política fechado sobre si mesmo, definido apenas pela conquista do poder, enquanto os problemas concretos perdem o conteúdo, sendo convertidos apenas no objeto de disputas por espaço político.

Outro ponto crítico focalizado pelo autor é a linguagem. A mídia é responsável pela conversão do discurso político às suas regras, especialmente a televisão, na qual se destaca o peso da imagem dos políticos, a fragmentação e a superficialidade. Os próprios políticos acabam adaptando seu discurso a falas de poucos segundos, buscando o efeito acima de tudo, como forma de alcançarem audiência e notoriedade. A complexidade dessas relações aumenta quando se considera que o próprio campo da mídia não é autônomo, incorporando objetivos advindos do campo econômico, representando lobbies empresariais, empreiteiras ou concessionárias de serviços públicos.

Para Miguel (2003), a democracia representativa trouxe modificações importantes ao conceito original de democracia, ao implicar a escolha de representantes, a formação dos partidos políticos, as eleições. Além dessas modificações e a partir delas, as campanhas eleitorais trouxeram o peso da agenda pública para o processo de es- 
colha dos representantes pelos eleitores, evidenciando a importância da informação no processo político, de modo a condicionar a escolha eleitoral. Há, portanto, além da representação formal, uma segunda dimensão da representação política, representada pelo agendamento dos temas e sua hierarquização. Essa dimensão estaria muito influenciada pelos meios de comunicação, pelo processo conhecido como agenda setting, tornando os demais grupos de interesse da sociedade consumidores da informação. Se esses grupos desejarem introduzir questões na agenda pública precisam sensibilizar os meios de comunicação. O debate público não se limita, pois, ao parlamento, mas envolve toda a sociedade, de modo que a mídia tem uma função determinante, agendando os temas do debate e dando a eles determinado enquadramento. Nesse sentido, para Miguel, a representação política significa tanto participar das tomadas de decisão em nome de outros como participar da produção da agenda pública em nome de outros, que é a função da mídia:

Essa segunda dimensão é necessária porque, em sociedades populosas, extensas e complexas como as contemporâneas, a participação direta de todos no debate público é inviável. Da mesma maneira como a impossibilidade de tomada direta de decisões pelo povo torna imprescindível a representação parlamentar, a impossibilidade de uma discussão envolvendo a todos gera a necessidade da representação das diferentes vozes da sociedade no debate público. (2003, p.133)

No entanto, essa representação, como o autor já destacara no texto anterior, é enviesada porque sofre a influência dos proprietários dos meios, dos anunciantes, da posição social dos jornalistas, da pressão da competição pelos leitores. Como conclusão, há necessidade de uma democratização da comunicação, o que não é tarefa fácil, devido à permanente distinção entre produtores e consumidores de informação, reflexo da diferença entre cidadãos comuns e seus representantes. Um conjunto de providências na direção da democratização implicaria desde a desconcentração da propriedade dos meios até a 
qualificação do público para a interpretação das informações que recebe.

Em outro texto, Miguel afirma que entre os problemas da implementação efetiva da democracia nas sociedades contemporâneas situa-se, em particular, a questão da qualidade do fluxo das informações a que o cidadão tem acesso (2004). Para ele, os meios de comunicação seriam "intrusos" no funcionamento da democracia, pois os partidos é que deveriam estar em posição de centralidade, como intermediários do jogo político. Mas essa ideia parece estar em contradição com análises anteriores, nas quais Miguel identificou a ação da mídia como outra face da representação política, colocação bastante pertinente sobre a natureza da luta política contemporânea, na qual, como já frisara Rubim (2000), os meios formam o verdadeiro ambiente e não simples apêndices ou acessórios.

No contexto da perspectiva crítica, destaca-se a questão da concentração e oligopolização dos meios. Investigador dos efeitos dessa tendência das comunicações no processo democrático, Lima (1997) concentrou grande parte de seus estudos sobre o papel da Rede Globo na vida política brasileira. Ele indaga:

Nesse novo quadro que se configura, haverá ainda espaço para o desenvolvimento do livre mercado, da competição e da própria democracia liberal? Será possível conciliar oligopólio e monopólios dos mídia com livre debate de ideias e opinião pública autônoma? $\mathrm{O}$ pluralismo e a diversidade ainda serão possíveis ou já será tarde demais para se fazer frente à "nova lógica" do mercado? Será inevitável a consolidação de uma "democracia oligopolizada" em que o setor de comunicações permanecerá também oligopolizado? (p.148-9)

McChesney (1999), na mesma direção, considera que os meios se tornaram uma força antidemocrática, devido à sua concentração em poucas mãos, afastando-os dos ideais liberais e reforçando a tendência para o comercialismo, implodindo a vida pública. Para ele, o que acontece nos Estados Unidos nem de longe se aproxima de uma sociedade democrática, pois muitas decisões-chave são o campo 
do setor corporativo e a maior parte das decisões governamentais é influenciada por interesses de grupos, com pequena participação ou divulgação pública.

\section{Hegemonia e democracia}

Nosso intuito, nesta parte, é tentar situar a questão da democracia num quadro de correlação de forças sociais, procurando uma concepção que não se deixe capturar pelas antinomias examinadas. Parece-nos que tanto as perspectivas liberais como as abordagens críticas podem conduzir a concepções reducionistas da inserção social, do papel e do caráter da ação política dos meios. As duas perspectivas apresentam-se como absolutos que se confrontam, preparando ciladas que aprisionam e imobilizam a análise do problema. A perspectiva liberal adota uma visão idealizada e não-contraditória da sociedade, que não corresponde aos fatos observados, consagrando o existente como promotor de uma harmonia perfeita, de modo que não critica as práticas vigentes nem vê necessidade de seu aprimoramento. Em sentido contrário, a perspectiva crítica, ao não atribuir qualquer valor democrático à comunicação na economia de mercado, também não alimenta qualquer esperança de aprimoramento dos meios no âmbito do capitalismo. Na ausência de uma alternativa revolucionária, restaria denunciar eternamente o quadro atual. Nem a ingenuidade nem a descrença parecem favorecer o processo democrático.

No entanto, a nosso ver, cada uma das perspectivas possui elementos de verdade ou, pelo menos, observáveis, mas que precisam ser reavaliados, com vistas à construção de um modelo mais apto a representar a relação da comunicação com a democracia no mundo empírico.

Primeiramente, considerando os pressupostos liberais, parece defensável teoricamente que meios de comunicação independentes tenham um papel importante na crítica da condução e administração da coisa pública, na informação dos cidadãos sobre os temas relevan- 
tes da vida coletiva, sendo um elemento importante na promoção da democracia. A limitação dessa perspectiva é que a dinâmica social é mais complexa que a doutrina liberal, que identifica diretamente os meios com o interesse público, não reconhecendo que a propriedade privada pode introduzir uma perspectiva de classe às suas pautas, o que, obviamente, conspira contra o ideal democrático de um debate público equilibrado. Novelli (2004) notou essa ambiguidade da imprensa dizendo que enquanto empresa privada ela não precisa submeter-se às regras que presidem os órgãos públicos, mas ao mesmo tempo participa do debate político, sendo vista como um serviço público e reivindicando o prestígio de uma instituição pública.

Em direção contrária, a abordagem crítica, ao abordar os meios no contexto das relações sociais, em situações concretas, permite aproximações mais realistas e está apoiada por um sem número de estudos empíricos e analíticos, que trouxeram evidências às suas posições. Porém, a tendência dessa abordagem a restringir a ação dos meios à perspectiva dos proprietários não lhe permite considerar a possibilidade de uma representatividade ampliada da ação dos meios, promovida por pressões internas ou externas a eles. A noção de hegemonia, a nosso ver, forneceria à perspectiva crítica um modo mais matizado de interpretação do significado e do papel complexo das comunicações na sociedade contemporânea, tendo sido usada nesse sentido tanto pelo próprio formulador, como por autores contemporâneos.

Coutinho (s. d.) ressalta a atualidade desse conceito na elaboração de uma teoria da democracia, lembrando que Gramsci foi, no contexto do pensamento marxista, o autor que mais desenvolveu uma reflexão criativa e original sobre a hegemonia, capaz de "fornecer preciosas pistas para superar muitos dos impasses em que se tem debatido até hoje a teoria democrática”. Ele argumenta que se tem em Gramsci "uma nova visão de democracia, nova não só em relação à tradição marxista, mas também - e sobretudo - em relação à tradição liberal".

É certo que os meios de comunicação são instrumentos de construção da hegemonia, mas, como se sabe, na formulação de Gramsci esse 
conceito vai além da dominação pura e simples, implicando reformas ou concessões, graças às quais uma classe logra a liderança intelectual e moral sobre as demais. Observamos que a referência a concessões pressupõe, necessariamente, a existência de pressões e demandas provenientes de outras classes sociais, de modo que o conceito não deve ser lido como expressão de uma magnanimidade da classe hegemônica, mas sua resposta estratégica, num contexto agônico. De qualquer maneira, a classe hegemônica vai além de seus interesses econômicos imediatos, a fim de lograr o consentimento social, unindo categorias e classes de uma sociedade num bloco histórico, no qual vigeria um princípio de organização das instituições e das práticas sociais.

Transportando essa concepção da vida política para o campo da comunicação, podemos supor que, além de atenderem aos objetivos imediatos dos grupos proprietários e aos interesses das classes hegemônicas, os meios noticiosos precisariam ultrapassá-los e representar algumas demandas das demais classes sociais, até mesmo para atender o restrito objetivo mercadológico, pois os interesses da classe empresarial não são necessariamente os das suas audiências e estas, embora se possa admitir que sejam influenciáveis por suas visões de mundo, apresentam demandas específicas. Os meios precisariam, portanto, alargar o âmbito de suas pautas, falar a linguagem e abordar os temas de contingentes maiores, contemplando, pelo menos, os interesses da classe média. No limite, porém, há uma consciência geral nas sociedades contemporâneas de que os extremos de desigualdades econômicas e sociais, por exemplo, não são defensáveis sob nenhum ponto de vista, nem mesmo os mais utilitaristas e que, portanto, os problemas e demandas das camadas subalternas e dos setores excluídos também precisam estar representados nos meios (embora o sejam de forma precária e eventual). Ou seja, talvez haja consensos mínimos nas sociedades contemporâneas que envolvam também os conteúdos dos meios de comunicação.

As análises dos noticiários identificam agendas e enquadramentos noticiosos que majoritariamente se poderiam considerar sintonizados com os interesses e preocupações dos grupos proprietários, das elites empresariais em geral. Mas esses resultados não definem automatica- 
mente os conteúdos dos meios para sempre. Embora se possam traçar certas características gerais balizadoras das pautas da comunicação de massa numa sociedade capitalista, sua posição a respeito de um determinado tema ou sua ação específica no processo democrático numa dada conjuntura são fatos de natureza histórica, ou seja, sua conduta depende da correlação de forças num dado momento, da ação de pessoas, de categorias sociais, entidades, movimentos sociais, não podendo ser totalmente determinadas de antemão. Isso implica, além da variabilidade das situações, que a comunicação pode também ser vista como um espaço de luta pela democracia, num processo permanente. Ou seja, não se trata de acomodar-se, mas de buscar a ampliação do âmbito de preocupações e interesses dos meios.

Um dos autores brasileiros que trabalharam na construção de uma formulação teórica relacionando a mídia à política por meio do conceito de hegemonia é Lima (2001), que desenvolveu o já mencionado conceito de cenário de representação da política (CR-P) para indicar o lugar e objeto da articulação da hegemonia, no qual se expressam, se refletem e se constroem os significados da política. O conceito de CR-P inspiraria diversos trabalhos realizados ao longo da década, oferecendo um modelo bem fundamentado e testado, que serviria de referência para o estudo dos pleitos à Presidência da República ocorridos nos anos 1990.

Mas a luta pela democratização da sociedade e da política não se trava unicamente no âmbito dos meios: se é verdade que a comunicação é importante para a democracia, em sentido contrário a existência ou não da democracia é uma condicionante decisiva da natureza da comunicação que se pratica. A linha de determinação entre os dois termos tem um vetor mais forte que vai da garantia de condições gerais da convivência democrática (vigência do Estado de Direito, liberdades públicas, garantias individuais, império da lei etc.) em direção à comunicação.

A história das transformações radicais das orientações do jornal Folha da tarde, durante e após o regime militar, escrita por Beatriz Kushnir (2004), constitui um relato precioso dessa engrenagem que articula a questão da vigência ou não da democracia política às 
práticas mediáticas concretas de redação e edição jornalísticas. Mas é possível ir além das garantias básicas, dos direitos fundamentais de liberdade de expressão, de modo a incluir políticas que promovam e incentivem formas públicas de comunicação democrática, atuando paralelamente aos meios comerciais. Uma discussão sobre alternativas de organizações mediáticas não poderia ser desenvolvida aqui, mas o tema tem sido objeto de trabalhos de Miguel (2004b), Fonseca (2004) e Curran (apud Baker, 2001).

Por último, é preciso estabelecer distinções nas análises do papel de cada um dos diferentes meios de comunicação na democracia. Há uma enorme diferença entre a imprensa e a televisão, por exemplo, facilmente observável por diversos critérios, tanto de linguagem como de profundidade e cunho analítico, interpretativo. Além do mais, não existe semelhança alguma entre a influência política de um meio de comunicação local ou regional e uma rede de televisão nacional oligopólica. Dada a deformação que pode exercer no processo democrático pela simples densidade de sua massa, pela desigualdade de sua influência social em comparação com qualquer outro meio, mas principalmente por não enfrentar qualquer contraditório, na ausência de concorrência, a rede oligopólica constitui sempre uma ameaça potencial para a democracia. Nesse sentido, a questão principal na análise do binômio comunicação-democracia continua sendo, sem dúvida, a concentração da propriedade, que induz à concentração das audiências e, portanto, ao gigantismo das influências.

A comunicação na sociedade contemporânea realiza-se, portanto, num contexto de classes com interesses divergentes e conflitos, mas há consensos mínimos compartilhados. Nesse quadro complexo, em permanente tensão, o papel da atividade jornalística na realização da democracia é marcado pela luta por espaços e enquadramentos. Rejeitando definições categóricas ou visões essencialistas, em prol de uma visão histórica da ação do jornalismo, entendemos que, em vez de uma atuação uniforme e previsível, seu papel resulta da influência de diversas forças, num quadro de valores profissionais, sociais e políticos, no qual jornalistas e demais cidadãos são confrontados em situações concretas. 


\section{Referências bibliográficas}

ALBUQUERQUE, A. Um outro "Quarto Poder": imprensa e compromisso político no Brasil. Contracampo, Niterói, V.1, no. 4, 2000.

ANSART, P. Ideologias, conflitos e poder. Rio de Janeiro: J. Zahar, 1978.

BAKER, C. E. Media, markets and democracy. West Nyack: Cambridge University Press, 2001.

COUTINHO, C. N. Gramsci: um estudo sobre seu pensamento político. Civilização Brasileira, 1999. Atualidade de Gramsci. s. d.

http://www.acessa.com/gramsci/?page=visualizar\&id=293. Acesso em 10/01/2005.

CUNNINGHAM, F. Theories of democracy: a critical introduction. Florence: Routledge, 2001.

CURRAN, J. Media and power. Londres/Nova Iorque, 2006.

Mass media and democracy revisited. In: CURRAN, J., GUREVICH, M. (Eds.) Mass media and society. Londres/N.York/Sidney/ Aukland: Arnold, 1996.

FALLOWS, J. Breaking the news: how the media undermine American democracy. Nova Iorque: Vintage Books, 1997.

FONSECA, F. C. P.Mídia e democracia: falsas confluências. Revista de Sociologia e Política. Curitiba, n.22, jun 2004. p.13-24.

GRUPPI, L. O conceito de hegemonia em Gramsci. S. Paulo: Graal, 2000.

KUSHNIR, B. Cães de guarda: jornalistas e censores, do AI-5 à Constituição de 1988.

São Paulo: Boitempo, 2004.

LATTMAN-WELTMAN, F. Mídia e accountability: dimensões e condições da poliarquia. Trabalho apresentado ao X Encontro Anual da Associação Nacional dos Programas de Pós-Graduação em Comunicação (COMPÓS), Brasília/DF, 29 de maio a 1 de junho de 2001. Disponível em: http://www.unb.br/fac/comunicacaoepolitica/2001.html.

LIMA, V. A. Mídia, teoria e política. São Paulo: Fundação Perseu Abramo, 2001.

Comunicações, política e democracia. In: TRINDADE, A. A. C. e CASTRO, M. F. A sociedade democrática no final do século. Brasília: Paralelo 15, 1997.

LINS DA SILVA, C. E. (Coord.) Comunicação, hegemonia e contrainformação. São Paulo: Cortez-Intercom, 1982. 
MADRID, J. E. Meios de comunicação e construção da hegemonia. In: LINS DA SILVA, C. E. (Coord.) Comunicação, hegemonia e contrainformação. São Paulo: Cortez-Intercom, 1982.

McQUAIL, D. Mass Communication Theory. Londres/Thousand Oaks/ New Delhi: Sage, 2000.

MARCONDES FILHO, C. O capital da notícia. São Paulo: Ática, 1989.

McCHESNEY, R. Rich media, poor democracy: communication politics in dubious times. Nova Iorque: The New Press, 1999.

Corporate media and the threat to democracy. Nova Iorque: Seven Stories Press, 1997.

MENDONÇA, A. S. Comunicação e teoria da hegemonia. In: LINS DA SILVA, C. E. (Coord.) Comunicação, hegemonia e contrainformação. São Paulo: Cortez-Intercom, 1982.

MERTON, R. K. \& LAZARSFELD, P. F. Comunicação de massa, gosto popular e a organização da ação social. In: LIMA, L. C. (Org.), Teoria da cultura de massa, Rio de Janeiro: Paz \& Terra, 1990.

MIGUEL, L. F. Influência e resistência: em busca de um modelo complexo da relação mídia/política. Trabalho apresentado ao X Encontro Anual da Associação Nacional dos Programas de Pós-Graduação em Comunicação (COMPÓS), Brasília/DF, 29 de maio a 1 de junho de 2001. Disponível em: http://www.unb.br/fac/comunicacaoepolitica/2001.html.

Representação política em 3-D: elementos para uma teoria ampliada da representação política. Revista Brasileira de Ciências Sociais. v.18 n.51. São Paulo, fev. 2003.

Mídia e vínculo eleitoral: a literatura internacional e o caso brasileiro. Opinião pública, Campinas, V.X, n.1, p.91-111, maio, 2004.

Modelos utópicos de comunicação de massa para a democracia. Trabalho apresentado ao XIII Encontro Anual da Associação Nacional dos Programas de Pós-Graduação em Comunicação (COMPÓS), São Bernardo do Campo, 22 a 25 de junho de 2004b. Disponível em http:// www.unb.br/fac/comunicacaoepolitica/2004.html

NOVELLI, A. L. O projeto Folha e a negação do quarto poder. In: MOTTA, L. G. (Org.) Imprensa e poder. Brasília: UnB-Imprensa Oficial, 2002. RIBEIRO, R. J. A república. São Paulo: Publifolha, 2001.

RUBIM, A. A. C. Comunicação É política. S. Paulo: Hacker, 2000.

SCHEMENT, J. R. Encyclopedia of communication and information. Nova Iorque/Farmington Hills: Macmillan Reference, 2002.

WOLTON, D. As contradições do espaço público mediatizado. Revista de comunicação e linguagens. Comunicação e Política. Lisboa: Cosmos, 21-22, 1995. 434p. Edição especial. p.167-88. 



\section{6 \\ Papel dos meios informativos NAS LUTAS DA CIDADANIA ${ }^{1}$}

Sem as instituições ou o espírito da democracia, os jornalistas são reduzidos a propagandistas ou a entretenedores.

James Carey

\section{Introdução}

Nosso propósito com este capítulo é discutir o papel do jornalismo no processo de conquista e vigilância dos direitos civis, políticos e sociais dos cidadãos. Realiza preliminarmente uma retrospectiva histórica dos sentidos da cidadania, até os sentidos contemporâneos para, em seguida, examinar algumas possibilidades da intervenção da comunicação jornalística na sua efetivação. $\mathrm{O}$ texto conclui formulando algumas reflexões sobre a natureza do jornalismo e a complexidade de sua participação nos processos sociais, nos quais pode desempenhar um papel de agendamento de temas relevantes para os cidadãos.

1 Uma versão preliminar deste trabalho foi apresentada na sessão de comunicações "Comunicação e Cidadania" da 9a Jornada Interdisciplinar, realizada na Faac-Unesp, no período de 20 a 22 de novembro de 2007. 


\section{Sentidos da cidadania}

Embora a noção de cidadania remonte à Antiguidade, originalmente dizia respeito aos privilégios de classes, ou estamentos superiores, sendo indicativa de uma discriminação das camadas sociais subalternas. Nas cidades e cidades-estado da Grécia, ela geralmente era um atributo de proprietários, mas não de mulheres, escravos ou dos mais pobres membros da comunidade. Entre os romanos, originalmente, a cidadania correspondia a privilégios legais importantes da oligarquia, formada pelos patrícios, proprietários rurais que detinham o monopólio dos cargos públicos e religiosos, sendo os únicos cidadãos de pleno direito. Apesar dessa origem, ao longo de muitas lutas, os plebeus progressivamente conquistaram grandes avanços em termos de direitos de cidadania (Funari in Pinsky \& Pinsky, 2003). Quando ressurgiu, no final da Idade Média e na Renascença, a cidadania em várias cidades da Itália e Alemanha era garantia de imunidade para mercadores e outras pessoas privilegiadas contra as pretensões e prerrogativas de senhores feudais. Em suas origens, como se vê, tratava-se, portanto, de um conceito regressivo, que atuava como instrumento destinado a marcar um exclusivismo social.

Contemporaneamente, ao contrário dessas versões "antigas", discriminatórias, a tônica tem sido a luta por uma "cidadania para todos" (Singer in Pinsky \& Pinsky, 2003), tornando-se um conceito cada vez mais inclusivo, a partir do século XVIII originalmente, com um sentido libertário, indicando a posse de direitos dos indivíduos em face dos poderes de monarcas absolutistas. As monarquias governaram "súditos", ou seja, "submetidos", enquanto a república ao instaurar propriamente o campo da política tinha por base os cidadãos, pessoas autônomas, em condições de eleger governantes e participar do governo.

Kant diferenciou a cidadania ativa, relativa aos que estão aptos a votar, da cidadania passiva, a dos que não têm autonomia para se expressar e, portanto, votar. Entre esses incluía as mulheres, as crianças e aqueles impedidos de votar pela sua condição social, os 
quais, apesar disso, deviam ser considerados livres e iguais como "homens", na comunidade política. A crítica feminista a esse conceito universal de cidadania adverte, porém, que cidadania igual para todos requer o reconhecimento das desigualdades: a ficção do cidadão universal pode atuar em detrimento dos que estão em desvantagem. Por isso, Lanoux (2007) propõe uma concepção alargada de cidadão como co-habitante, ou seja, aquele que tem os direitos da cidadania, compartilhando o espaço democrático.

Bottomore (1996) distingue a cidadania formal da substantiva. A primeira ecoa a conceituação antiga, na medida em que se refere à relação entre um indivíduo e um Estado, ao qual um indivíduo deve obediência, recebendo, em contrapartida, proteção. Há diversos modos de aquisição da cidadania formal, que corresponde aproximadamente ao sentido de "nacionalidade", como o nascimento em certo território, a descendência de pais cidadãos, casamento com um cidadão, naturalização. Apesar do formalismo, é um tema muito relevante contemporaneamente, devido à existência hoje de enormes contingentes de imigrantes, exilados ou refugiados vivendo em países estrangeiros, para quem ela acaba sendo determinante da sua situação legal e de suas perspectivas.

A noção de cidadania substantiva, por sua vez, implica que os cidadãos têm certos direitos, começando pelos políticos, como o de votar e de ser votado, que são negados ou apenas parcialmente estendidos a estrangeiros e outros não-cidadãos residentes em um país (aos quais não se atribua cidadania formal). Trata-se de uma construção histórica, em expansão, ligada hoje a muitos aspectos da vida, significando o acesso dos cidadãos à saúde, à educação, à previdência, à cultura, à comunicação etc.

A concepção de cidadania hoje tem como referência frequente a obra do sociólogo inglês H. T. Marshall (1967), que distingue três momentos na luta pelos direitos. Analisando o caso específico da Inglaterra, ele diz que os direitos civis teriam se consolidado no século XVIII, os direitos políticos no século XIX e os direitos sociais no século XX. Os direitos civis são considerados pelo autor os que caracterizam a liberdade individual, como o direito de ir e vir, a 
liberdade de pensamento, de contrato, de propriedade, bem como o direito à justiça, necessária à defesa desses direitos. Direitos políticos, para Marshall, são os que permitem participar do poder político, como votar e ser votado. Os direitos sociais são os que garantem um mínimo de bem-estar e segurança. Um comentarista crítico destacou a forma estruturada como é apresentado o argumento:

(...) É importante indicar aqui que, para Marshall, essa evolução parece irreversível (pelo menos, no caso inglês), e a conquista de cada um desses elencos de direitos parece servir como ponto de apoio para a conquista do elenco seguinte. Desenha-se assim, no texto de Marshall, um processo de conquista de direitos em escada, o que sugere a ideia de uma evolução natural da cidadania. Finalmente, Marshall nos propõe uma avaliação sociológica - que se tornou um objeto permanente de polêmica na ciência política anglo-saxã - da relação entre o desenvolvimento do capitalismo e a evolução da cidadania. A instauração dos direitos civis teria sido indispensável à própria implantação do capitalismo, já que sem tais direitos os homens não poderiam participar livremente do mercado, seja como compradores, seja como vendedores da força de trabalho. (Saes, 2000, p.7-8)

Para Marshall (1967), a cidadania traz implícita a noção de igualdade, embora seu desenvolvimento coincida com a supremacia do capitalismo, baseado na desigualdade entre as classes sociais. Apesar disso, ele defende que o princípio da cidadania não conflitaria com o de classes sociais, porque eles têm origens distintas: enquanto as classes se enraízam na propriedade e na estrutura econômica, a cidadania está ligada ao direito, sendo concedida aos membros de uma comunidade, que são iguais em direitos e obrigações. ${ }^{2} \mathrm{Na}$ interpretação de Gentilli (2005), os direitos civis defendem a liberdade

2 Saes (2000), no entanto, a esse respeito, contra-argumenta, dizendo que a cidadania política é inviável no capitalismo, justamente devido à série de distorções introduzidas no processo democrático pela desigualdade econômica, sendo que a controvérsia a esse respeito abrangeria tanto autores da esquerda como conservadores e progressistas. 
dos indivíduos contra a ação do Estado; os direitos políticos - por meio do regime democrático - estabelecem as formas de participar do poder do Estado; por último, os direitos sociais reclamam a ação do Estado no provimento de benefícios, serviços e renda para as camadas economicamente mais vulneráveis da sociedade.

Os direitos sociais podem vir a restringir alguns direitos civis, especialmente aqueles que se referem à propriedade privada. Não se exclui, portanto, a ideia de uma tensão entre os direitos, reclamando a busca de um equilíbrio. Bottomore (1996), por exemplo, observa que durante o século XX, os regimes comunistas limitaram direitos civis e políticos nos países em que foram estabelecidos, embora pudessem proporcionar direitos sociais. Após décadas no poder, esses regimes foram extintos por movimentos que reivindicavam a restauração das liberdades e direitos políticos, bem como a independência das instituições da sociedade civil em relação ao Estado. Direitos civis, políticos e sociais devem ser vistos, pois, como autênticas conquistas históricas, que precisam ser preservadas, reclamando uma integração de uns com os outros, não devendo ser tratados como mutuamente exclusivos, sob pena de retrocessos em termos de cidadania. ${ }^{3}$

Touraine (1994) diz que a cidadania, na modernidade, é consequência da secularização, que tornou o individuo o centro de referência, fazendo com que os seres humanos busquem a legitimidade por meio de critérios racionais: "O ser humano não é mais uma criatura feita por Deus à sua imagem, mas um ator social definido por papéis, isto é, pelas condutas ligadas ao status e que devem contribuir para organizar e regulamentar as suas relações" (Touraine, 1994, p.26 apud Fernandes, 2002, p.3). O cidadão é o sujeito principal da secularização e liga-se a outros cidadãos por leis e regras criadas por seres humanos, ou seja, sempre arbitradas e, portanto, questionáveis. A conquista dos direitos civis, explica Touraine, significou para a burguesia o desaparecimento do controle do governo e da religião

3 Esse argumento foi formulado por Renato Janine Ribeiro em palestra, na qual se referiu às ideias da "boa política" como sendo a democracia, a república, o liberalismo e o socialismo. 
sobre a atividade econômica, legitimando o modo de produção capitalista. A partir daí, outras categorias sociais passam a lutar por direitos à cidadania e por benefícios da nova ordem econômica, que deveriam ser promovidos pela ação do Estado: são os direitos sociais, como os direitos à saúde, à moradia, educação, trabalho etc. (Fernandes, 2002).

Sendo históricos, há nas sociedades democráticas uma permanente busca pela conquista de novos direitos a partir dos já adquiridos, de modo que, num movimento social imprevisível, os seres humanos vão reinventando a cidadania. Para Bobbio (1992 apud Fernandes, 2002), a Declaração Universal dos Direitos Humanos de 1948 deu a partida para a luta por uma nova geração de direitos, como os à paz, a um ambiente despoluído, à utilização do patrimônio comum da humanidade. Outra passagem foi aquela do foco no ser humano genérico para o foco em seres humanos específicos, tomados na diversidade de seus status sociais (gênero, idade, condições físicas), cujas diferenças peculiares não admitem tratamento e proteção iguais às dos demais. A crítica feminista a um conceito universal de cidadania, por exemplo, adverte que cidadania igual para todos requer o reconhecimento das desigualdades: a ficção do cidadão universal atua em detrimento de alguns, como indivíduos com limitações mentais, por exemplo, que não têm direito a votar. Por isso, propõe uma noção alargada de cidadão como co-habitante, ou seja, aquele que tem os direitos da cidadania, compartilhando o espaço democrático (Lanoux, 2007).

Fernandes (2002) observa que depois do fracasso nas sociedades contemporâneas de concepções teóricas e de estratégias políticas incapazes de articular a multiplicidade de pleitos por uma vida melhor, a cidadania tornou-se para muitos movimentos sociais um tema central, porta de entrada dos sujeitos no espaço público, no qual apresentam interesses diversos, convocando a sociedade a examinar suas questões, abrindo a discussão em busca do entendimento e da legitimidade de suas reivindicações de direitos.

$\mathrm{O}$ apelo à cidadania expressa-se hoje por essa contínua entrada em cena de novos atores que procuram constituir-se como autori- 
dades para falar de si mesmos. Cidadania, além de ser sentimento de pertencimento a uma nação, a uma comunidade, a um projeto da sociedade moderna, vai sendo também relacionada à capacidade desses atores articularem demandas e apresentarem soluções. Os direitos não estão postos eternamente, mas os grupos e os indivíduos refazem-nos, alteram-nos e lutam para inscrevê-los em forma de leis. Não há uma certeza, uma norma fixa. Os cidadãos podem, em princípio, apresentar seus problemas, interesses, valores e eventuais soluções, a partir de suas próprias visões de mundo. Esse conflito permanente força a linha dos limites dos direitos, tornando-a expansiva (idem, p.5).

\section{Jornalismo e cidadania: a visão normativa}

Faremos agora algumas considerações sobre o tema específico, envolvendo as relações entre o jornalismo e a construção da cidadania. Em outras palavras, examinaremos o significado e papel desempenhado pela imprensa na ampliação, consolidação e disseminação dos direitos relativos à cidadania. Esta análise examinará dois enfoques distintos: o de caráter normativo, na linha de direito, que estabelece os princípios de uma imprensa comprometida com a cidadania, e o outro, crítico, que se apoia na observação das condições históricas em que atua a imprensa, especialmente em países capitalistas. Vamos examinar a primeira dessas alternativas.

O enfoque normativo do tema da cidadania, em vez de observar e analisar a forma como ocorrem os fenômenos sociais, pressupõe teoricamente certos princípios racionais, expressos como direitos, ainda que não estejam sendo aplicados concretamente. No caso do jornalismo, por exemplo, a abordagem normativa considera, preliminarmente, a informação como um direito civil, que se manifesta pela liberdade de expressão, ou seja, pela liberdade de difundir informações sem censura, de criar jornais (Gentilli, 2005).

Para Gentilli, o direito civil à informação é um pressuposto necessário à realização dos direitos políticos, constituindo um dos direitos 
relativos à esfera pública, como a liberdade de opinião e de expressão, liberdade de imprensa, liberdade de reunião e de associação. Keane (1998) revelou como a liberdade de imprensa - enquanto direito civil - foi defendida com entusiasmo, na Inglaterra do século XVIII, "como um direito de nascença dos ingleses", sendo que a imprensa livre se tornaria, ela própria, o palco para a discussão de outros direitos políticos e sociais, ao longo dos séculos seguintes. "A informação jornalística é, simplesmente, indispensável para o estar no mundo nos dias de hoje. O que alguns autores chamam de "necessidade social da informação' é hoje suprida sobretudo pelo jornalismo" (Gentilli, 2005, p.125).

Gentilli considera que a "sociedade dos cidadãos" é a "democracia do poder visível", ou "o governo do poder público", conforme preconiza Bobbio (2000). Ora, a visibilidade da democracia exige a publicidade dos fatos relativos à esfera pública. Dessa forma, ele deduz que os cidadãos precisam de acesso à informação pública para exercerem seus direitos de acesso ao poder político, e ao exercício pleno do conjunto dos direitos da cidadania:

É neste contexto, de fornecer as condições para um juízo do cidadão, que se deve pensar o conceito de "direito à informação. A questão pode ser vista a partir de duas vertentes: (1) O direito à informação deve ser pensado na perspectiva de um direito para todos. (2) O direito à informação deve ser pensado na perspectiva de fornecer informações em quantidade e qualidade para o melhor julgamento possível de cada um". (Gentilli, 2005, p.129-30)

Para o autor, o acesso à informação é um "direito-meio" que dá acesso aos demais direitos, entendidos como "direitos-fim”. É por meio da informação que os cidadãos podem fazer escolhas e julgamentos de forma autônoma, de modo que ela os auxilia a exercerem suas prerrogativas, tornando, por meio de sua difusão, mais acessíveis os demais direitos.

Penso o jornalismo como uma atividade indispensável no mundo contemporâneo, como o instrumento que viabiliza o direito à 
informação, no qual os jornais desempenham a função de mediadores e os jornalistas, individualmente, de representantes do leitor, telespectador e ouvinte, como indivíduos, consumidores e cidadãos (idem, p.142).

Nessa abordagem, os jornais, num modelo típico-ideal, formariam uma instituição social, mesmo sendo empresas privadas, porque "desempenham a função pública de atender aos direitos à informação” (idem, p.147). Há uma responsabilidade dos meios para com a sociedade, independente de se esses meios são públicos ou privados, pois embora sejam instituições livres, prestam contas à Justiça e aos cidadãos. No entanto, embora o jornalismo seja uma importante forma do direito à informação, não é a única: quando os cidadãos não têm uma determinada informação necessária, o Estado deve oferecê-la da mesma maneira como deve fornecer outros serviços de natureza social (idem).

A cidadania concerne, portanto, ao próprio direito à informação, traduzido em questões como acesso aos meios, comunicação pública, inclusão digital. Como observou Martins (2006), devemse distinguir: a) o direito de saber; b) a necessidade de saber e c) o desejo de saber. Os dois primeiros dizem respeito especificamente ao interesse público, enquanto o último se refere ao chamado "interesse do público".

O direito de saber corresponde, por um lado, ao princípio da publicidade dos atos do governo, da visibilidade, da transparência que caracterizam o regime republicano, envolvendo a divulgação das ações do governo, a produção de dados estatísticos, que são cobertos pelo jornalismo de assuntos públicos e da administração. Por outro lado, a nosso ver, inclui ações de governo e do jornalismo na defesa dos direitos da cidadania, como a divulgação dos direitos pelos órgãos públicos e a denúncia das violações e cobrança de reparações, a divulgação das lutas pela consolidação e ampliação dos direitos das maiorias. Incluímos no direito de saber a temática específica da comunicação em saúde, advertindo sobre riscos à saúde coletiva, comunicando a oferta de serviços públicos como consultas, vacinação e distribuição de produtos; difundindo cuidados de prevenção 
e promovendo estilos de vida saudáveis. A comunicação em saúde é responsável pela divulgação das informações tão vitais à saúde coletiva que será preciso passar a vê-las no Brasil como obrigação do Estado.

Já a necessidade de saber refere-se às informações de utilidade pública produzidas - seja pelo governo, seja pela sociedade civil que visam orientar os cidadãos, como dados do mercado, meteorologia etc.

Por último, o desejo de saber compreende as informações sobre temas-espetáculo, que visam mais ao entretenimento da audiência por apelos estéticos, sensuais e catárticos, preenchendo a vida real de imaginário. É objeto de muitas críticas, especialmente por ser um tipo de conteúdo majoritário, em especial nos meios eletrônicos, banalizando, frequentemente, temas de interesse público por meio de versões espetaculares.

\section{Jornalismo e cidadania: a abordagem crítica}

A grande imprensa continua invocando os ideais liberais do século XVIII, especialmente para combater a regulamentação das comunicações, mas hoje o contexto é totalmente diferente. Para Keane (1998), já não se trata mais de cidadãos a lutar contra o absolutismo, censura estatal, pela escolha individual, pela desregulamentação das proibições monárquicas, pela competição do mercado, mas de corporações poderosas que fizeram desaparecer a competição, num contexto em que as liberdades em relação ao poder político já estão estabelecidas e no qual o grande poder está no mercado.

O liberalismo de mercado interpreta a 'liberdade de imprensa' como o resultado de uma luta longa e heroica de empreendedores privados para se libertarem das obrigações e restrições que o governo ou 'o público' podiam tentar impor. [...] O problema é que o liberalismo de mercado não mostra que os mercados são estruturas complexas dentro das quais os tomadores de decisão corporativa 
agem como censores. A competição de mercado produz a censura de mercado. (idem, p.90). ${ }^{4}$

A publicidade encoraja a mudança da diversidade da informação em direção ao entretenimento, age a favor dos anunciantes e contra os cidadãos, privilegia a fala corporativa. $\mathrm{O}$ "mercado de comunicação restringe a liberdade de comunicação, gerando barreiras à entrada, monopólio e restrições à escolha". O consumidor venceu o cidadão: os indivíduos são tratados como consumidores liderados pelo mercado e não como cidadãos ativos com direitos e obrigações (idem). Além disso, as desigualdades sociais afetam o direito à informação: cidadãos empregados e com boa renda podem pagar por acesso aos meios noticiosos analíticos, enquanto os mais pobres só têm acesso à TV aberta e ao rádio.

Outra maneira de enfocar a atuação dos meios noticiosos, no caso da cidadania, é observar a distância entre o que se poderia chamar de "âmbito social dos meios" e o âmbito social das reivindicações de direitos sociais, distância que se traduzirá na limitada preocupação dos meios com relação às reivindicações sociais. O "âmbito" dos meios é o circuito constituído por editores, jornalistas e pelos leitores (que provêm, em geral, da classe média), enquanto os direitos sociais são, via de regra, reivindicados pelas maiorias, que são os pobres.

É possível supor, portanto, que, em parte, os temas sociais não frequentem as preocupações de diretores de jornais, jornalistas e mesmo leitores por uma questão de pertencimento social. Para ilustrar esse ponto, gostaríamos de citar a edição da Folha de S. Paulo de 11 de novembro de 2007, em matéria intitulada "Leitor da Folha está

4 O argumento também é usado por Marcondes Filho, em "O capital da notícia" (1997): "Quando os proprietários de jornais clamam por liberdade de imprensa, não estão batalhando pela supressão geral da censura, mas pela supressão desta como esfera de monopólio do Estado. O monopólio elas pleiteiam para si próprios. Liberdade de imprensa não significa liberdade para informar o que é necessário à sociedade, mas sim liberdade para que a censura dependa somente dos donos de jornal" (Marcondes Filho, 1989, p.100). 
no topo da pirâmide social brasileira". Diz o texto que reproduz uma pesquisa do Datafolha, agência de pesquisas de mercado do jornal:

O leitor da Folha está no topo da pirâmide da população brasileira: 68\% têm nível superior (no país, só 11\% passaram pela universidade) e $90 \%$ pertencem às classes $\mathrm{A}$ e $\mathrm{B}$ (contra $18 \%$ dos brasileiros). A maioria é branca, católica, casada, tem filhos e um bicho de estimação.

A maior parcela dos leitores tem entre 23 e 49 anos, é usuária de internet, faz exercícios e frequenta restaurantes, shoppings, cinema e livrarias. [...]

O leitor é superequipado - tem DVD, celular, computador e câmara digital - e faz uso intenso da internet: a maioria usa buscadores, compara preços, faz pesquisas de trabalho, usa MSN (programa para conversa na rede), faz download de programas e ouve músicas.

São consumidores vorazes de mídia: $92 \%$ assistem a telejornais, $69 \%$ leem revistas, $58 \%$ ouvem notícias no rádio e $57 \%$ seguem noticiário on-line. O meio impresso, porém, é o preferido dos entrevistados: se tivessem que optar por um, $53 \%$ ficariam apenas com o jornal.

O interesse do jornal em conhecer seu "público" nada tem de excepcional, do ponto de vista das estratégias mercadológicas. No entanto, ao visualizar leitores situados numa faixa de renda elevada, com grau de instrução superior, exercendo profissões de status alto, com um estilo de vida marcado pelo consumo sofisticado, usuário de tecnologia avançada, ou seja, com uma inserção social diferenciada do conjunto da sociedade brasileira, a publicação parece sinalizar que a probabilidade de serem agendados certos temas de interesse desse segmento é maior do que outros.

Enquanto os meios parecem representar razoavelmente as questões que envolvem interesses do mercado e até da classe média, o mesmo não ocorre com igual intensidade no caso das maiorias, especialmente os marginalizados. Haveria um "limiar" limitado de preocupação dos meios com esses temas, um intervalo no qual os meios poderiam incluir demandas sociais da cidadania social ampliada. No 
entanto, a perspectiva recorrente dos meios parece tender à cobertura preferencial do status quo econômico, dando espaço maior a temas de política econômica, como "equilíbrio fiscal" ou "fundamentos econômicos", sem a sua contrapartida social.

Há também, por um lado, uma preferência por temas políticos institucionais, relacionados aos poderes Executivo e Legislativo, às candidaturas à presidência, dedicando-se, por outro lado, um espaço reduzido à permanente crise social brasileira e à situação calamitosa das camadas subalternas. As demandas sociais (ou mesmo que não tenham chegado a se constituir em demandas, os "temas sociais"), apesar de desesperadoras, não formam um conjunto de assuntos destacado no conjunto do noticiário. O jornalismo só tangenciaria as questões sociais, em especial nos eventos pontuais agudos (acidentes, calamidades, ocupações), de modo que os direitos sociais ligados à terceira geração da cidadania não formam um assunto privilegiado pela imprensa.

É mais fácil o lançamento de uma coleção de roupas da moda do verão obter uma página no jornal diário do que uma reportagem sobre sub-habitações urbanas conseguir esse destaque. Enquanto a sub-habitação é o cenário secular da sociedade brasileira, ou seja, algo com menor valor-notícia, porque não tem o fator novidade, os novos modelos de um estilista se apoiam exatamente nesse fator. Aparentemente, só em circunstâncias especiais um assunto da esfera da cidadania social assoma o campo do noticiário da grande imprensa. Como hipótese, poderíamos dizer que os meios noticiosos representam bem as questões do mercado e da classe média (consumidora, compradora e leitora dos jornais e revistas) e de forma limitada os temas que afligem as maiorias de forma crônica.

O problema da sub-representação das questões da cidadania social decorreria também da natureza do jornalismo praticado num contexto de mercado, focalizado em critérios de noticiabilidade que privilegiam os acontecimentos pontuais, as pessoas importantes, o número, o impacto imediato e não os processos de longa duração. Nesse caso, as camadas mais pobres da sociedade só alcançariam visibilidade no noticiário em ocorrências pontuais extremas: acidentes, chacinas, confrontações, calamidades, ocupações. Essas situações adquirem valor- 
notícia ou se inserem nos critérios acadêmicos de noticiabilidade pelo número de pessoas envolvidas, pela negatividade ou pelo tom emocional das histórias pessoais e não como indicativos de injustiças, assimetrias sociais, desigualdade de oportunidades e de renda, exclusão histórica, condição de moradia etc. No entanto, cessadas as circunstâncias imediatas do acontecimento, o assunto tende a desaparecer do noticiário ou a restringir-se a pequenas notas nas páginas policiais.

\section{O jornalismo cívico}

Questões colocadas em torno dos compromissos do jornalismo com a cidadania também vêm instigando jornalistas norte-americanos em busca de alternativas, levando muitos jornais a desenvolverem, desde a década de 1990, projetos denominados public journalism ou civic journalism (Lambeth, 1998; Traquina, 2001; Fernandes, 2002). Trata-se de uma modalidade de ação jornalística que visa ajudar as pessoas a superarem "a sensação de impotência e alienação, desafiando-as a envolver-se e a tomar para si a responsabilidade sobre problemas comunitários" (Schaffer, 2001 apud Fernandes, 2002, p.96). Com o apoio de fundações, esses experimentos foram implementados em cerca de duzentas organizações noticiosas que procuraram se conectar com os leitores não apenas de forma convencional, mas enquanto cidadãos, procurando estimular a participação mais informada nos assuntos públicos e elevar a qualidade da deliberação pública, buscando responder a algumas das questões consideradas mais prementes das comunidades dos leitores, tais como o crime juvenil, a desagregação familiar, relacionamento racial e estagnação das economias locais (Lambeth, 1998).

Os jornais cujos projetos mais se destacaram, situados em cidades pequenas e médias do interior dos Estados Unidos, ${ }^{5}$ enviaram seus repórteres para ouvirem as pessoas, fazendo coberturas com popu-

5 Wichita eagle, de Wichita, Kansas; Charlotte observer, de Charlotte, Carolina do Norte e Norfolk Virginian pilot, Norfolk. 
lares; encomendaram sondagens de opinião; afastaram-se das coberturas eleitorais estilo "corrida de cavalos"; procuraram, por meio de pesquisas, conhecer as preocupações dos eleitores e estimularam os candidatos a uma exposição mais explícita dos seus argumentos. Um dos jornais, o Eagle, motivou os cidadãos a pensarem sobre os grandes assuntos e cobriu histórias de sucesso, oferecendo dicas de formas pelas quais os cidadãos podiam se envolver na busca de soluções, e convidou-os para discussões por escrito ou pessoalmente. Um projeto em parceria, adotando os princípios e os temas do civic journalism, denominado Nós, o povo, ${ }^{6}$ envolveu jornais e um canal de televisão, que aumentou o interesse em temas públicos mais do que a ação isolada de um único veículo (idem).

Um dos jornalistas mais envolvidos com o projeto de jornalismo cívico, Davis Merrit, diretor do Wichita eagle, defende que o jornalismo deve ir além de dar as notícias, visando a uma missão mais ampla, de contribuir para melhorar a vida pública, deixando de lado a noção de observador desprendido, substituindo-a pelo papel de participante justo. Para ele, é necessário conceber os leitores não como consumidores, mas como atores da vida democrática, ou seja, como cidadãos (Traquina, 2001). O jornalismo cívico norte-americano quer colocar o cidadão atuante, participando da solução dos problemas, especialmente porque os problemas focalizados nos experimentos estão ao alcance das comunidades e não envolvem políticas nacionais.

Alguns princípios do jornalismo cívico podem, eventualmente, ser observados na prática jornalística tanto de jornais como de telejornais brasileiros e, provavelmente, não por coincidência, o que significa que, malgrado as limitações do jornalismo brasileiro, aprimoramentos são introduzidos a partir de exemplos, especialmente quando merecem atenção e discussão. No caso dos grandes jornais brasileiros, em vez de buscar a participação direta dos cidadãos na resolução dos problemas, há uma tendência a remeter a solução para as políticas públicas do Estado, o que parece adequado, no que se refere a questões estruturais. Percebe-se, hoje, uma sensibilidade

6 O projeto foi desenvolvido em Madison, Wisconsin, Estados Unidos. 
maior em relação aos direitos individuais (situação dos detentos, tortura policial, execuções sumárias), cujas violações são acompanhadas pela imprensa insistentemente, até que providências sejam anunciadas. Uma entidade como a Agência Nacional dos Direitos da Infância (Andi) vem há anos pesquisando, divulgando e estimulando o noticiário sobre temas envolvendo a infância e adolescência, e esse acompanhamento pode influenciar a conduta das editorias, pois casos de violação de direitos e agressões envolvendo adolescentes têm ganhado espaço e tempo crescentes nos meios, indicando uma atenção redobrada para essa temática.

A nosso ver, há, porém, certo descuido com relação aos temas relativos aos direitos sociais. Problemas como a concentração de renda e desigualdade, habitação precária, concentração fundiária, questões urbanas como transporte coletivo, saneamento básico, educação, saúde, lazer e acesso à cultura não costumam ser tratados de forma constante pelos meios. Silva cita uma pesquisa do MEC mostrando que $84 \%$ das matérias sobre educação surgidas na imprensa brasileira basearam-se em fontes governamentais, o que, segundo ele, mostraria que os meios não têm tido iniciativa de cobrir um tema de grande interesse da cidadania. Para o autor, "no Brasil, os direitos humanos e os direitos sociais ainda não encontraram na imprensa, e na mídia em geral, espaços tão dedicados como os que são concedidos aos direitos do consumidor" (Silva in Motta, 2002, p.65).

A nosso ver, na ausência de dados, para responder à pergunta sobre como o jornalismo brasileiro incorpora os temas da cidadania, é possível, impressionisticamente, anotar sinais contraditórios: em alguns momentos o jornalismo tem estado atento, mas não sempre, nem de forma sistemática. O que o caso do jornalismo cívico parece mostrar é que, apesar das diferenças entre os Estados Unidos e o Brasil, em grande parte, as mudanças dependem de decisões para acontecer, de um projeto, de um ímpeto numa determinada direção, ou seja, de um critério normativo. Não há uma essência imutável do jornalismo: feito por seres humanos, capazes de deliberação, ele pode mudar por vontade de seus praticantes. Mas, sobretudo, é importante que ele assuma um compromisso de tipo normativo 
com a sociedade, mesmo considerando a natureza empresarial dos meios de comunicação.

\section{Jornais e sociedade}

Quando se discute o papel da imprensa nos temas da cidadania, pensa-se que a imprensa tenha algum tipo de poder capaz de influir nos processos sociais. No entanto, a rigor, o chamado "poder da imprensa" é um poder simbólico. Poder social efetivo é a capacidade de fazer as coisas acontecerem, como as instâncias do Estado, que podem ou produzir leis, ou criar programas de ação, ou fazer investimentos em áreas que consideram importante, atuando de maneira direta sobre as realidades. O poder da imprensa está na sua capacidade de agendar os temas, enquadrá-los, colocando-os publicamente. Estudando o papel da cobertura do Congresso Nacional por quatro jornais, Rodrigues (2002) conclui que ocorre um efeito de agendamento da ação dos parlamentares, influindo no trabalho de comissões, nos discursos, nas discussões, enfim na ação dos parlamentares, colocando temas latentes. Mas apesar de a autora sugerir uma influência direta, ela também pode exercer influência sobre os cidadãos, de modo a, eventualmente, formar uma corrente de opinião capaz de pressionar as autoridades (do Executivo, do Ministério Público, do Legislativo etc.) a tomarem uma atitude a respeito, por estarem sendo observadas pelos cidadãos-eleitores. Essa ação triangular é, inclusive, reconhecida por Rodrigues, que apresenta um esquema circular do processo de agendamento. Ela escreve que "a imprensa agenda o Congresso porque agenda a opinião pública, que agenda a imprensa, que agenda o Congresso, que agenda a imprensa, que agenda a opinião pública" (in Motta, 2002, p.121). O modelo tem o mérito de não isolar os meios informativos do conjunto da sociedade, como se fossem agentes externos a ela. Pelo contrário, coloca os meios - numa democracia - como instâncias da sociedade civil produtoras de significados, que interagem com as instituições e com as audiências num único processo. 
Opinião pública

\section{$\uparrow \downarrow \uparrow \downarrow$}

Congresso $\rightarrow$ Imprensa

Figura 3. Representação do processo de agendamento

Fonte: Rodrigues in Motta, 2002

O nível de efetividade da ação da imprensa depende do grau de mobilização social alcançado. Se a sociedade civil estiver apática, é possível, mas mais difícil levar a consequências das denúncias e pressões. Dar publicidade aos acontecimentos constitui a essência do trabalho da imprensa, mas pressupõe implicitamente a existência dos leitores (cidadãos). Ou seja, a força da publicidade dada aos acontecimentos advém da coletividade, que toma conhecimento dos fatos publicados e espera providências. Schudson (2003) considera que a ação de distribuir informação tem consequências porque ao fazê-lo os jornais amplificam os acontecimentos, estimulam a interação social numa outra escala, conferem uma certificação de importância e dão saliência ao significado moral dos fatos reportados.

No entanto, há bastante tempo, críticos apontam as limitações dos cidadãos contemporâneos diante dos fatos de uma sociedade altamente complexa, que lhes são apresentados pela imprensa. Num texto clássico, Merton \& Lazarsfeld (in Costa Lima, 1978) referiam-se à condição dos indivíduos bem informados, conscientes dos grandes problemas nacionais, que vão dormir certos de terem cumprido seu dever como cidadãos: o de se informarem adequadamente sobre as questões, mesmo sem nada terem feito a propósito. Chamaram a isso "disfunção narcotizante", porque entenderam que os meios informativos atuavam como autênticos narcóticos sociais que dopariam as pessoas, limitando sua ação efetiva. Dominique Wolton (2004) ecoa hoje essa crítica, ao dizer que a boa informação é condição necessária ao exercício da cidadania, na sociedade 
contemporânea, mas que apesar de bem informado, o cidadão hoje tem pouca capacidade de ação e de decisão. Em termos práticos, o poder dos cidadãos dá-se de forma indireta, por meio das correntes de opinião que podem (ou não) influenciar a deliberação e a ação dos detentores de mandatos populares.

Uma forma de poder, alternativo ao do Estado, só surgiria, portanto, como resultado da interação efetiva entre a ação dos meios noticiosos e a mobilização efetiva dos leitores, por exemplo, por meio de movimentos sociais, manifestações públicas, passeatas, panelaços, apitaços, abaixo-assinados, atos públicos etc. Ou seja, não é razoável supor que o jornalismo possa substituir os cidadãos, que são os detentores do poder, mas ele pode contribuir com sua atuação específica: agendar temas para o debate público racional. A esse respeito, Schudson também argumenta que a notícia não é autônoma, que é preciso ver os meios noticiosos no contexto de outras forças sociais e políticas, como parte do que ele denomina ecologia da comunicação pública. Para ele, "não se trata de decidir o impacto das notícias na democracia (ou da democracia sobre as notícias), mas [de perceber] o caráter mutuamente constitutivo de ambas" (2003, p.31).

Algumas vezes, no entanto, mesmo com a publicidade dada aos acontecimentos, com uma tendência da opinião pública, com uma mobilização, os representantes ou o Executivo acabam deliberando de forma corporativa, ignorando as inclinações manifestadas pela sociedade. A política brasileira recente oferece inúmeros exemplos de situações em que a imprensa revelou problemas, fez críticas, parte da sociedade secundou essas críticas e o governo (Executivo ou Legislativo) passou ao largo dessas vontades, adotando os procedimentos que considerou adequados.

Essas considerações contraditórias sugerem, portanto, que os caminhos que levam as ações dos meios e as pressões dos cidadãos a resultados concretos são tortuosos e que as relações entre o jornalismo e o exercício da cidadania não são sempre consequentes, mas dependem de uma série de circunstâncias peculiares, ou seja, são contingentes. As observações não visam a desacreditar o papel da imprensa e o debate público racional, na concretização dos direitos 
políticos e sociais da cidadania, mas visam relativizar esse papel, ou seja, considerá-lo como um elemento (importante) numa constelação de fatores que atuam de forma complexa no processo histórico total.

\section{Considerações finais do capítulo}

Entre as qualidades geralmente esperadas do jornalismo costumase colocar a imparcialidade, mas o jornalismo cívico indicou que essa não é a visão mais adequada à perspectiva de uma atuação em favor da cidadania. Para esta última, é mais importante considerar que o jornalismo tem compromissos, desde o início, com a defesa dos direitos, o que implica, por exemplo, ser a favor das liberdades, da justiça, dos direitos políticos e sociais. Defende-se o equilíbrio do jornalismo, mas este não quer dizer apatia: um jornalismo indiferente às questões da cidadania seria, a rigor, uma monstruosidade, pois significaria tratar como equivalentes alternativas com valores radicalmente opostos. Diante de um caso de desrespeito aos direitos humanos, como uma execução sumária, ou de trabalho escravo, significaria tratar esses assuntos de forma ambígua, relativizando sua avaliação, e não como algo intrinsecamente mau. Na verdade, espera-se do jornal a defesa dos direitos individuais e coletivos mais avançados e a denúncia dos retrocessos. A adoção dessa linha de base não se dá em prejuízo da correção da reportagem, que deve ser baseada na apuração acurada dos fatos, nos protocolos profissionais, na narrativa independente. Porém, na perspectiva normativa que defendemos, o jornalismo é uma atividade que se legitima por atuar em favor da cidadania e existe para defendê-la, contra cujo ideal conspira, por exemplo, o jornalismo sensacionalista, nos contextos de exaltação ou de justificação da violência.

Nessa direção, percebe-se que na sociedade brasileira, profundamente marcada pela desigualdade e pela exclusão das maiorias de serviços essenciais, existe um espaço muito importante de atuação do jornalismo pelos direitos sociais da cidadania. Jornais, revistas e telejornais nem sempre agendam os problemas sociais, ou não o fazem 
numa frequência compatível com a magnitude desses problemas na realidade, nem dão a eles um espaço ou tempo correspondentes a essa dimensão. No entanto, esses temas, pela gravidade das consequências humanas e pela amplitude dos contingentes populacionais que eles envolvem, são problemas de toda a sociedade, sobre a qual acabam por ter um impacto. Por conseguinte, o jornalismo, considerado como instrumento da esfera pública, por meio do qual os cidadãos tomam consciência de sua realidade e a discutem, deveria - numa visão normativa - representar de forma adequada essa realidade, privilegiando as questões mais relevantes e que alcançam as maiorias, mesmo que essas questões não envolvam diretamente os jornalistas, proprietários de meios de comunicação ou suas audiências.

A correção jornalística também implica, paradoxalmente, não tratar como consensuais questões controvertidas. A sociedade contemporânea, em decorrência das mudanças e transformações muito rápidas, está repleta de temas polêmicos e de incertezas, sobre cujo significado não existe uma opinião unânime ou sobre as quais diferentes instituições ou pessoas têm pontos de vista conflitantes. Nesse caso, o papel da imprensa deve ser exatamente expor a controvérsia, reportando as ideias de todos os lados envolvidos, de forma a constituir-se em veículo e lugar da discussão pública pelos cidadãos.

No estudo do papel da imprensa no fortalecimento da cidadania entrevimos a tensão entre o normativo (o tipo ideal) e o empírico (a realidade imperfeita e complexa). Os valores normativos representam a imprensa como um instrumento de defesa da cidadania, enquanto a abordagem empírica critica as deformações que o poder político e econômico pode impor a essa atividade. Mas as imperfeições da realidade não constituem uma condenação dos princípios, que devem continuar sendo a meta buscada. A resultante da interação entre princípios e realidade da imprensa como empresa capitalista, numa democracia, não é uma posição rígida, sendo mais bem representada pela imagem de um móbile. Caracterizado pelo equilíbrio instável entre suas partes móveis, resultado da ação de pesos e contra-pesos, quando o móbile é tocado, os elementos fazem o conjunto oscilar num intervalo variável, devido à ação das suas peças, mas um bom 
móbile não vai pender unicamente para um lado. Num modelo da sociedade democrática, em que os direitos estão em vigor e as instituições funcionam, a imprensa como uma dessas instituições sofre pressões antagônicas, como a dos critérios normativos de seus compromissos e a das forças do mercado, e deve traduzi-las na forma de um equilíbrio dinâmico.

\section{Referências bibliográficas}

BOBBIO, N. A era dos direitos. Rio de Janeiro: Campus, 1992.

BOTTOMORE, T. Cidadania. In: BOTTOMORE, T., Outhwaite, W. Dicionário do pensamento social do século XX. Rio de Janeiro: J. Zahar Editor, 1996. p.73-4.

ESTEVES, J. L. M. Cidadania e judicialização dos conflitos sociais. Disponível em: http://www2.uel.br/cesa/direito/doc/estado/artigos/ constitucional/Cidadania\%20e\%20Judicializa\%C3\%A7\%C3\%A3०\%20 dos\%20Conflitos\%20Sociais.pdf.

FERNANDES, A. F. Jornalismo, cidadania e direitos humanos: uma relação reflexiva no espaço público. Trabalho apresentado no Núcleo de Pesquisa Jornalismo, XXV Congresso Anual em Ciência da Comunicação, Salvador, set. 2002. Disponível em: http://reposcom.portcom.intercom.org. br/bitstream/1904/18665/1/2002_NP2FERNANDES.pdf.

FERNANDES, M. Jornalismo cívico: um estudo comparado dos modelos americano e brasileiro. In: HOHLFELDT, A., BARBOSA, M. Jornalismo no século XXI: a cidadania. Porto Alegre: Mercado Aberto, 2002. p.95-108.

FUNARI, P. P. A cidadania entre os romanos. In: PINSKY, J. e PINSKY, C. B. (Org.) História da cidania. São Paulo: Contexto, 2003. p.49-79.

GENTILILLI, V. Democracia de massas: jornalismo e cidadania. Porto Alegre: EDIPUCRS, 2005.

KEANE, J. The media and democracy. Cambridge: Polity Press, 1998.

KUNSCH, M. M. K. Campos de estudos emergentes em comunicação nas novas cidadanias. In: BEZZON, L. C. (Org.) Comunicação, política e sociedade. Campinas: Alínea, 2005. p.21-44.

LAMBETH, E. B. Does civic journalism have a future? In: SALVADOR, M., SIAS, P. M. (Eds.). The public voice in a democracy at risk. Westport: Praeger, 1998. p.115-26. 
LANOIX, M. The citizen in question. Hypatia. v.22, n.4 (Fall, 2007). p.113-29.

MARSHALL, T. H. Cidadania, classe social e status. Rio de Janeiro: Zahar, 1967.

MERTON, R. K. e LAZARSFELD, P. F. Comunicação de massa, gosto popular e a organização da ação social. In: LIMA, L. C. (Org.) Teoria da cultura de massa. Rio de Janeiro: Paz e Terra, 2000. p.109-31.

MIGUEL, L. F. Influência e resistência: em busca de um modelo complexo da relação mídia/política. Trabalho apresentado ao X Encontro Anual da Associação Nacional dos Programas de Pós-Graduação em Comunicação (COMPÓS), Brasília/DF, 29 de maio a 1 de junho de 2001. Disponível em: http://www.unb.br/fac/comunicacaoepolitica/2001.html.

RODRIGUES, M. R. Agendando o Congresso Nacional: do agenda-setting à crise da democracia representativa. In: MOTTA, L. G. Imprensa e poder. Brasília/São Paulo: Editora da UNB/Imprensa Oficial SP, 2002. p.103-23.

SAES, D. A. M. de. Cidadania e capitalismo: uma crítica à concepção liberal de cidadania. Disponível em: http://www.unicamp.br/cemarx/ criticamarxista/16saes.pdf.

SCHUDSON, M. The power of news. Cambridge/Londres: Harvard University Press, 2003.

SILVA, L. M. da. Imprensa e cidadania: possibilidades e contradições. In: MOTTA, L. G. (Org.) Imprensa e poder. Brasília/São Paulo: Editora da UNB/Imprensa Oficial SP, 2002. p.47-74.

SINGER, P. A cidadania para todos. In: PINSKY, J. \& PINSKY, C. B. (Org.) História da cidania. São Paulo: Contexto, 2003. p.191-263.

SOUZA, J. P. As notícias e os seus efeitos. 1995. Disponível em http:// bocc.ubi.pt.

TRAQUINA, N. O estudo do jornalismo no século XX. São Leopoldo: Ed. da Unisinos, 2001.

WOLTON, D. Pensar a comunicação. Brasília: Editora UNB, 2004. 

Parte III

VERIFICAÇõES E ANÁLISES 



\section{7 \\ Cenários de representação da POLÍTICA NAS ELEIÇÕES PRESIDENCIAIS BRASILEIRAS $^{1}$}

\section{Introdução}

Em 2006, o torneiro mecânico Luiz Inácio Lula da Silva foi reeleito presidente da República do Brasil, após concorrer em cinco eleições presidenciais, em três das quais foi o segundo colocado nas votações. Tomando a trajetória singular de Lula na política brasileira, partimos dela para um exame em perspectiva da mídia em relação a suas campanhas nesses pleitos. $\mathrm{O}$ capítulo realiza, pois, um retrospecto das pesquisas sobre a mídia e as eleições brasileiras, desenvolvidas por mim e por outros pesquisadores, utilizando o conceito de cenário de representação da política (Lima, 1994), buscando discutir sua influência em cada campanha. Desejamos examinar nesses pleitos a afirmação do autor de que o fator decisivo nos processos eleitorais é o cenário instaurado pela televisão, em especial, no caso brasileiro, pela Rede Globo. Aqui, quando houve dados suficientes, o foco esteve dirigido para a análise do papel específico do Jornal Nacional, o principal telejornal da rede, na construção do cenário, mas a análise da eleição de 2006 sugere a transição de um

1 Versão parcial deste texto foi apresentada no Seminário Temático de Comunicação e Política da Anpocs, em 2004. 
modelo centrado nos meios hegemônicos para formas capilarizadas de influência simbólica.

\section{O ambiente mediático e o significado da eleição}

Considerando a natureza simbólica do processo político, alguns estudos têm concebido a escolha do candidato como o resultado do processo de atribuição de significado ao voto, em resposta a uma dada conjuntura, interpretada pela comunicação de massa. Assim, Robinson \& Charron (in Raboy \& Bruck, 1989) analisaram as formas de envolvimento dos meios na criação de significado público para o referendo do Quebec, de 1980, por meio da construção seletiva do conhecimento social. Os meios de comunicação participam da construção desse significado, ao apresentarem um rol de valores, objetivos e estilos de vida, buscando o consenso público sobre os temas principais. Para os autores, o significado público constitui o quadro de referência por meio do qual diferentes grupos sociais entendem sua própria realidade.

Na mesma direção, Missika \& Bregman (1987) concluem que o significado de um pleito resulta de uma negociação, pela qual um sentido coletivo é dado ao voto. Os estudos sobre o processo de agendamento realizado pelos meios mostram que estes têm um papel importante na definição das prioridades políticas, durante uma campanha, ao enfatizarem certos temas em detrimento de outros. Os temas da campanha são apresentados ao público sob a forma de controvérsias, diante das quais os eleitores tomam suas decisões e a opinião pública adquire uma nova forma, em resposta a cada nova situação política criada.

Essas pesquisas pressupõem que os cidadãos não possuem necessariamente um grupo coerente de preferências antes de fazerem uma escolha eleitoral: são os partidos que estabelecem os problemas, ou as controvérsias, sobre as quais se darão as escolhas, havendo uma forte relação entre a escolha de uma controvérsia e os resultados das eleições. A controvérsia é que constrói a opinião pública e é sobre 
ela que os atores políticos serão julgados. O eleitorado decide o voto com base nos recursos de que dispõe: imagens dos partidos e dos candidatos, visões difusas do mundo político, informações disseminadas pelos meios de comunicação e pela própria propaganda política. Condensando, simplificando e sumarizando as principais controvérsias, os meios de comunicação negociariam o significado do voto.

No Brasil, como já relatado, Venício Artur de Lima, procurando examinar o papel da televisão nos processos eleitorais, formulou o conceito de Cenário de Representação da Política (CR-P) (1994). O conceito tinha sido esboçado por Lima no seu estudo da eleição presidencial de 1989, no qual observava que um “cenário político” propício à candidatura de Collor vinha sendo construído a partir de 1986 por telejornais, em particular o Jornal nacional e outros programas jornalísticos da Rede Globo de Televisão (Globo repórter, Fantástico), pelas telenovelas da rede e pelas pesquisas. Lima observou, nesses programas, a focalização da corrupção que, justamente, viria a ser o tema central da campanha presidencial de Collor, a ponto de dar-lhe a fama de "caçador de marajás". Desde sua posse como governador de Alagoas, em 1986, Collor passou a ser apresentado nos principais programas jornalísticos da Globo tomando medidas contra os funcionários públicos "fantasmas" (denominação a servidores inoperantes) e contra os servidores com altos salários (os "marajás"), de modo que ele era, em 1989, a personagem mais adequada ao cenário construído pela rede de televisão de maior cobertura no país.

O autor elaboraria posteriormente uma minuciosa formulação do conceito de cenário de representação da política, CR-P (Lima, 1994 e 1995). No texto de 1994, ele diz que o CR-P constitui uma estrutura simbólica, contraditória e dinâmica, que assinala os limites nos quais se dão os conflitos políticos. O CR-P, segundo Lima, élugar e objeto da articulação da hegemonia, no qual se expressam, se refletem e se constroem os significados da política. Três pressupostos básicos sustentam essa noção, escreve ele: a existência de uma hegemonia, a existência de uma sociedade media-centric e a presença da TV como meio de comunicação dominante. Nos processos eleitorais, o CR-P 
hegemônico, construído pela televisão (em particular a Rede Globo, dada sua condição de superioridade entre as redes brasileiras), corresponderia à perspectiva e estratégia dos candidatos das classes hegemônicas na sociedade brasileira. Lima formula a hipótese de que uma proposta política dificilmente terá êxito ou um candidato vencerá eleições nacionais e majoritárias caso não se ajuste ao CR-P hegemônico, razão pela qual os candidatos utilizam os símbolos e as tradições culturais nacionais, tentando identificar-se com eles. Os elementos constitutivos do CR-P, para o autor, devem ser buscados nos programas de televisão, como noticiários, shows, novelas, filmes, e os gêneros de maior audiência devem merecer maior atenção.

O conceito, que passou a ser empregado por diversos pesquisadores nas análises dos processos eleitorais brasileiros, forneceu uma abordagem teórica que, a nosso ver, tentava dar conta analiticamente do papel avassalador da Rede Globo na cena política brasileira, como rede hegemônica, em condições de instaurar cenários de representação para a sociedade brasileira. A rede tem uma posição singular na história política brasileira, não só pelo fato de ser a "campeã de audiência", por concentrar as verbas do mercado da publicidade, mas também pela sua atuação deliberada na vida política brasileira, em diversos momentos documentados ao longo das últimas décadas (idem, 1989).

Aguiar(1993) examinou o papel da imprensa no processo político. Para ela, a imprensa dispõe o cenário e os atores, distribui a palavra, elege ou confirma temas para a discussão pública da política, contribuindo para a construção da própria ideia de política e de eleições, bem como de tudo o mais que seja pertinente e significativo para o país. Para a autora, a imprensa fornece representações para os outros meios de comunicação e, consequentemente, para toda a sociedade. Ela seria responsável pelo processo de agendamento por meio do qual o público atribuiria importância aos acontecimentos, pessoas e problemas difundidos pelos meios de comunicação. Segundo essa hipótese, a imprensa teria o papel de articulação dos significados dos fatos, constituindo o lugar por excelência no qual as sociedades elaboram simbolicamente a realidade, conferindo sentido a ela. 
O cenário das eleições não é, portanto, um dado bruto, como os efeitos de uma determinada conjuntura, experimentada diretamente, mas é uma representação construída, o resultado de diversos discursos, podendo ser concebido como interdiscursividade. Situação econômica, condições de vida, habitação, emprego, saúde, salários, serviços públicos, políticas públicas, bem como ocorrências pontuais intensas, no campo político ou social (greves, denúncias etc.) são variáveis que formam uma conjuntura. Mas, mais do que circunstâncias factuais do mundo empírico, o CR-P envolve aspectos significativos, constituídos pelo interdiscurso, os conformam à percepção dessas realidades, por meio de interpretações, veiculadas pelos meios de comunicação, em especial a televisão.

Com o objetivo de discutir o papel dos meios nas campanhas eleitorais, faremos um retrospecto comparativo de aspectos dos cenários de representação da política construídos pela TV nas quatro últimas eleições presidenciais, com destaque para o Jornal nacional, o programa jornalístico de maior influência da Rede Globo de Televisão, transmitido no horário nobre para todo o país, atingindo uma audiência maior que aquelas das demais redes. A tarefa de reconstituir os cenários sempre envolve algum arbítrio, seja na escolha dos corpus, seja na seleção de alguns em uma série enorme de aspectos que poderiam ser fixados pelo analista no estudo das representações. O estudo dos enquadramentos dos meios de comunicação parece ser o método mais seguro para controlar o risco das leituras impressionistas, já que são os meios que, no curto prazo, constroem privilegiadamente as representações sobre os fatos do mundo empírico.

Pretendemos pôr em evidência aspectos mais destacados dos cenários que se destacaram no jornalismo ou nos programas de entretenimento da televisão, baseando-nos em nossas próprias pesquisas, desenvolvidas no período, complementando-as com os trabalhos de outros pesquisadores. Eventualmente, alargamos o âmbito da investigação para enfocar outros meios de comunicação, além dos programas de TV, preconizados no conceito de CR-P, conforme a formulação de Lima. Como as eleições se deram num intervalo de tempo relativamente grande, sobre o qual não houve um estudo sis- 
temático continuado, este capítulo reúne observações independentes entre si, não há um padrão único quanto aos meios enfocados, ou seja, uma série histórica perfeita. Feitas essas ressalvas, as observações procuram estabelecer comparações e contrastes entre os processos eleitorais de 1989, 1994, 1998, 2002 e 2006, tomando como referência o conceito de cenário de representação da política.

\section{9: A Rede Globo em cena}

Lima (2001) investigou sistematicamente o papel da Rede Globo de Televisão na eleição presidencial de 1989, partindo do processo de construção do cenário político, antes de junho desse ano. Sua hipótese é de que o candidato Fernando Collor, apoiado por setores conservadores, adaptou sua imagem pública ao perfil de candidato ideal solicitado por esse cenário. Ele aparecia como o candidato capaz de resolver as questões nacionais, aliás, as mesmas tematizadas pela rede Globo. As novelas do período pré-eleitoral, Que rei sou eu? Vale tudo e $O$ salvador da pátria teriam preparado o cenário político que favoreceu Collor, ao desqualificarem a atividade política e os funcionários públicos, identificados com a corrupção, o fisiologismo e o desperdício: a política aparecia nessas novelas como atividade exercida contra os interesses da sociedade, enquanto os funcionários e políticos eram apresentados como autênticos "marajás". Por sua vez, o telejornalismo participou da construção do cenário político por meio de uma cobertura favorável a Collor e à sua suposta ação moralizadora desde que foi governador de Alagoas, empossado em 1987, dois anos antes da eleição presidencial.

Sabe-se que tão logo tomou posse como governador de Alagoas em 15 de março de 1987 Collor passou a ter cobertura nacional e, em maio de 1988, foi transferida da TV Globo-Brasília para a afiliada TV Gazeta-Maceió (da família Collor de Mello) a competente repórter Beatriz Castro, que cobriu os atos do novo governo, com presença assegurada no Jornal nacional, até duas vezes por semana... (idem, p.235) 
Lima anotou que, entre março e maio de 1989, Collor aparecia em programas como Globo repórter e Fantástico e de junho a agosto sua presença nos telejornais da Rede Globo foi maior do que a dos demais candidatos. Ele observa que seus concorrentes naquela eleição expressaram publicamente suas críticas à "campanha de manipulação da opinião pública” (Brizola) da TV Globo, na qual "o concessionário tornou-se tutor da opinião pública” (Aureliano Chaves).

O cenário seria completado com a antecipação da vitória de Collor por meio da divulgação dos resultados de sondagens de intenção de voto realizadas pelo Ibope, sob contrato da Rede Globo e simultaneamente consultor de Collor, apresentadas pelo Jornal nacional. Essas pesquisas, segundo Lima, passaram a ocupar um papel central na cobertura do processo eleitoral pela emissora, fixando o nome de Collor como o vencedor, constituindo "fator básico na construção do CR-P da eleição de 1989” (idem, p.240).

A partir de julho, a Globo não apenas constrói um cenário favorável a Collor mas beneficia diretamente sua candidatura em seu noticiário, seja omitindo fatos negativos, seja realizando uma cobertura intensiva de fatos negativos em relação a Brizola e Lula, seja dedicando um tempo bem maior ao preferido da rede de televisão. Comportamento semelhante é observado pelo autor com relação ao jornal O globo, que não só colocou o nome de Collor no maior número de títulos de matérias políticas $(30,9 \%)$ como a maioria esmagadora dessas matérias $(84,61 \%)$ lhe era favorável. Finalmente, Lima destaca a edição do último debate entre Collor e Lula, transmitido pelo Jornal nacional, às vésperas da votação do segundo turno, a qual selecionou as atuações mais agressivas de Collor e os momentos desfavoráveis de Lula.

Outros autores, estudando o papel da imprensa na eleição de 1989, observaram que Collor dispôs de farto espaço na mídia e uma "verdadeira adesão editorial dos principais órgãos de imprensa" (Lattman-Weltman, Carneiro e Ramos, 1994, p.22). Esse trabalho mostra que os quatro principais jornais do país adotaram um padrão similar no tratamento editorial das matérias sobre o então governador de Alagoas, sempre apresentado em ação, envolvido em conflitos 
e disputas, buscando a moralização do estado contra os marajás, investindo contra o presidente José Sarney, suspeito e impopular, amplificando a carga dramática de seu estilo. $\mathrm{O}$ padrão de atuação dos jornais analisados foi, em geral, conceder espaço aos seus adversários, Luís Inácio da Silva, o Lula e Leonel Brizola, realizando, entretanto, uma cobertura crítica de seus programas de governo, enquanto tratava superficialmente os problemas da candidatura de Collor, como a manipulação de slogans, o fisiologismo e o esbanjamento de recursos na campanha eleitoral.

Entre os temas que viriam a compor o cenário na imprensa em 1988 e 1989 figuravam as greves e os confrontos trabalhistas, de que o período foi pródigo. $\mathrm{O}$ tratamento dado a esses acontecimentos foi severo e negativo com relação ao movimento sindical, em particular à Central Única dos Trabalhadores (CUT), que apoiava Lula: “ao longo do ano e da campanha foi ressuscitada uma série de velhos fantasmas, como ameaças de fuga de empresários, ocupação de quartos de famílias da classe média por flagelados nordestinos, entre outras "pérolas"” (idem, p.44).

O resultado do segundo turno mostraria um eleitorado dividido quase simetricamente em dois, com a vitória de Collor por uma margem pequena de votos. Essa diferença irrisória revela como os apoios da mídia tiveram que ser muito especiais para que Collor pudesse vencer Lula. Ao mesmo tempo, a campanha de 1989 foi suficientemente longa para permitir que aparecesse uma imagem crítica de Collor, contraditória com a do "caçador de marajás" que ele apresentava nos seus programas eleitorais.

\section{4: O real e o imaginário}

Após o afastamento de Fernando Collor, até por causa desse fato mesmo, o cenário da política passou a ser propício, ao PT, até 1994. Afinal, o impeachment, motivado por denúncias de corrupção do governo, podia ser visto como a confirmação de todas as críticas que Lula tinha feito a Collor durante a campanha de 1989. Durante o 
mandato de seu sucessor, Itamar Franco - empossado por força da renúncia de Collor -, uma sucessão de temas críticos passou frequentar as manchetes na mídia, como os aumentos salariais de parlamentares e o escândalo do orçamento, que revelou desvios milionários, por meio de emendas propostas por deputados. A ação de parlamentares do Partido dos Trabalhadores ganhou muita visibilidade nos meios de comunicação em duas CPIs: a primeira, dos cheques fantasmas, que levou ao impeachment de Collor, e a outra gerada pelo escândalo do orçamento da União, que acabou redundando em absolvições, que pareciam atestar o corporativismo dos partidos tradicionais.

Os trabalhos das CPIs duraram meses, sendo transmitidos diariamente pelos telejornais e às vezes ao vivo, com novas e chocantes revelações, constituindo-se num autêntico espetáculo mediático. $\mathrm{O}$ fato de a corrupção e os escândalos não terem envolvido nenhum político do PT contribuiu para construir uma representação do partido como uma agremiação diferente, porque seus integrantes apresentavam conduta ilibada, livre dos desmandos e vantagens do poder. Durante os trabalhos parlamentares, a atuação de alguns integrantes mais destacados da pequena bancada do PT salientou-se pela correção e pela nitidez, apresentando parlamentares combativos e atuantes.

Já na controvérsia sobre a revisão constitucional, o PT colocou-se decisivamente contra, com a justificativa de preservar as conquistas sociais da Constituição de 1988, uma posição mais simples, objetiva, sintética e simpática. O descomprometimento do PT com o governo federal (nenhum membro do partido integrou o governo de Itamar Franco) também lhe permitiu uma grande liberdade de movimentos, a adoção de iniciativa crítica, bem como uma oposição mais veemente e menos condicional. Outros partidos, na medida em que participaram do governo, viram tolhidas as possibilidades de exibir posições mais recortadas e nítidas em questões como o processo de privatização das empresas estatais e o recrudescimento da taxa de inflação.

Em vários momentos, a imprensa mostrou os partidos políticos acomodados ao usufruto das vantagens do Estado e o parlamento foi diversas vezes criticado pela imprensa por sua acomodação, enquanto 
o PT exibia coerência, destacando-se, em todas as questões, do tom aparentemente mais conciliatório dos demais partidos. Em relação aos partidos poderosos, mas um tanto ambíguos, o PT contrastava por sua conduta de oposição íntegra, por sua atuação crítica nos episódios políticos, a qual ganharia força a partir do processo de impeachment. Em suma, a cobertura jornalística da política fixara uma imagem peculiar e favorável ao PT.

O cenário mais amplo também estivera a favor de Lula, praticamente desde o processo de impeachment, e essa situação perdurou durante todo o primeiro semestre de 1994. Lula era, tacitamente, o candidato natural à presidência, desde o segundo turno de 1989, quando o eleitorado brasileiro se dividira ao meio. O desastre representado pelo governo Collor, implicitamente, contrastava com o prestígio político de Lula, o antagonista, virtualmente identificado como o anti-Collor. A campanha eleitoral anterior e a derrocada do governo eleito até o drama do impeachment tinham tido um papel decisivo na definição de significado da candidatura Lula, que parecia refletir uma identidade política mais coerente, enfrentando, nesse sentido, poucos adversários. Pesquisa do Datafolha, divulgada em junho de 1994, permite observar que a candidatura de Lula apresentava um conteúdo de classe e de posicionamento político, em sentido estrito, ao contrário das demais. Algumas das razões de voto no candidato eram: "foi uma pessoa pobre/operário" (17\%), "representa os trabalhadores" (16\%) e "vai ajudar os pobres/é a favor da classe mais baixa" (12\%). Elas pareciam indicar um embrião de politização do voto, de base não-ideológica, um esboço de percepção da política como atividade pela qual as classes sociais se fazem representar no aparelho estatal. Essa orientação, vista simultaneamente com os elevados índices de intenção de voto em Lula, parecia formar um conjunto significativo coerente num quadro político marcado por ambiguidades. Mesmo sem desfrutar do apoio dos grupos ligados à comunicação de massa e até contra o desejo destes, na pesquisa do Datafolha realizada entre 9 e 13 de junho, Lula contava, naquele momento, com 41\% das intenções de voto, contra 19\% de Fernando Henrique, o adversário mais importante. Lula parecia, então, imbatível. 
O cenário político da sucessão do presidente Itamar Franco, na imprensa, não se afigurava como um ônus para o governo em face da oposição, como ocorrera em 1989, quando a liderança na confrontação com Sarney era disputada por todos candidatos, até o de seu partido. Mas, mais importante que isso, em 1994, o governo lançou o Plano Real de combate à inflação, que se daria em etapas e não trazia decepções para a sociedade como os fracassados planos Cruzado e Collor. ${ }^{2} \mathrm{O}$ fato de o principal oponente de Lula, Fernando Henrique Cardoso, sair do Ministério da Fazenda, na qualidade de candidato do governo, para a disputar a presidência, não representava, portanto, constrangimento a sua imagem política; pelo contrário, seria decisivo para sua vitória, por ser o responsável pelo sucesso na luta contra a inflação. Além de ser um plano econômico, correspondia à criação de um cenário de representação da política capaz de funcionar eleitoralmente, contando com o apoio dos meios de comunicação.

Os fatores potencialmente ameaçadores à candidatura do PSDB estavam na percepção de uma crescente violência urbana, na crise do sistema de saúde, no retorno da inflação descontrolada. Porém, esses problemas não podiam ser integralmente atribuídos a um governo empossado pelas contingências para cumprir um fim de mandato. Além disso, a base da candidatura de Fernando Henrique - o plano econômico da equipe do ex-ministro - apresentava-se justamente

2 Diferentemente dos anteriores, o Plano Real baseava-se na chamada "âncora cambial”. Foi criada inicialmente uma unidade de referência de valor (URV), equiparada ao dólar, para a qual, durante certo tempo, todos os preços do comércio deveriam obrigatoriamente ser convertidos. O plano, como se divulgou, pretendia apagar a "memória inflacionária" por meio da URV, que era estável em relação ao dólar, para só depois introduzir o Real. Em agosto de 1994, a moeda vigente (Cruzeiro Real) foi substituída por um novo numerário, o Real, cujo valor era o da antiga URV, que não tinha sido afetada pela inflação do período em que existira. O valor de um Real foi equiparado ao de um dólar em 1994 e essa paridade foi mantida fixa durante os anos seguintes. A âncora cambial promoveria um movimento importador sem precedentes e um aumento das viagens ao exterior. Internamente, por uma lado a paridade com o dólar garantia a manutenção dos preços, enquanto por outro, prejudicava a indústria nacional por meio da concorrência dos importados, que incluíam itens totalmente supérfluos como batatas fritas. 
como o primeiro passo para a solução dos problemas nacionais. Se o plano concebido dentro do governo Itamar era bom, a ideia de continuidade aparecia como desejável.

O plano econômico lançado por Cardoso, à frente do Ministério da Fazenda, do qual a substituição da moeda física era o aspecto mais espetacular e visível, trouxe matéria para a imprensa, durante meses. O nome da nova moeda dificilmente poderia ser melhor: depois de tantos anos de inflação crônica, teríamos, finalmente uma moeda "real", ou seja, de verdade. Houve, em seguida, a transfusão de dinheiro: todas as notas e moedas foram trocadas por toneladas de reais, numa operação de enorme magnitude. Foi uma espécie de exorcismo, uma liturgia de afastar as notas pecaminosas, para entronizar uma nova moeda, virginal, num ritual de purificação, cujo objetivo, além de simplesmente monetário, era, igualmente, retórico e dramático, marcando de maneira indelével o início de uma nova fase na vida brasileira.

Essa celebração da renovação, da quebra de vínculos com o passado, participou, sem dúvida, da instauração de um clima positivo, apagando a memória inflacionária, para que ela não contaminasse as esperanças dos brasileiros. Não bastasse a força intrínseca do ritual, havia uma oportuna particularidade no mecanismo de conversão. Nos planos anteriores, ao mudar a moeda, cortavam-se apenas os zeros. No Plano Real, uma unidade da nova moeda equivalia a 2.750 cruzeiros reais (a moeda anterior), de modo que para obter o valor convertido era preciso uma segunda operação, de multiplicação, criando, a impressão súbita de que os preços passavam a ser cerca de um terço dos valores antigos: a noção de valor foi, de repente, obnubilada. Olhando o cardápio da lanchonete ou o folheto do supermercado fazia-se involuntariamente uma confusão otimista de que o poder aquisitivo da nova unidade monetária era, aparentemente, maior. A nova moeda passara a equivaler a um dólar americano, fato que seria sistematicamente explorado na propaganda de Cardoso, que mostraria os itens que se podia comprar, então, com uma unidade da nova moeda. Mas, além das impressões, o Real conseguira, efetivamente, fazer cair drasticamente a inflação, estabelecendo um 
cenário de estabilidade monetária, o que, sem dúvida, representava um ganho para os assalariados, às voltas com aumentos constantes dos preços.

A economista Maria da Conceição Tavares afirmaria em uma reportagem que o plano não era eleitoreiro, era eleitoral. Uma forma de interpretar essa afirmação é dizer que o Real correspondia efetivamente a uma mudança monetária importante, mas, também, era posto em circulação num momento politicamente oportuno para o candidato que tinha sido responsável pela sua criação.

\section{O cenário no Jornal nacional}

Além da eficácia simbólica própria da moeda, como portadora de valor econômico, e da capilarização de seu significado pela circulação, que se imiscuiu em todas as relações econômicas do cotidiano, o real também se transformaria na vedete dos noticiários, de maneira natural e insuspeita, pois constituía um genuíno assunto jornalístico. Essa era uma de suas propriedades mais eficazes politicamente, pois justificava o agendamento do tema e abria espaço para enquadramentos favoráveis.

Uma análise do Jornal nacional realizada por Biroli (1995) mostrou como os enquadramentos dados ao plano orientavam percepções auspiciosas sobre os fatos. É possível observar a existência de uma estrutura padrão de enquadramento nas matérias sobre o Real: a simplificação das situações e os confrontos que exaltavam o ministro-personagem Ricupero, fixando de forma positiva o papel do Real. O tom das matérias referentes ao Plano era criado por meio da encenação de uma luta diária entre o governo, as forças do bem, e os preços altos. Significativamente, do lado do bem está o código do consumidor, chamado a sua "bíblia", enquanto os agentes do mal, estabelecimentos que abusam dos preços, formam a "lista negra" do Procon. As chamadas do telejornal são peremptórias: "Ministro da Fazenda se escandaliza com o preço das roupas", "Arma do governo é facilitar as importações"; "O preço da cesta básica pode cair ainda 
mais..."; "Alerta do ministro da Fazenda na guerra dos preços". Personagens dessa dramaturgia, de um lado, são, tipicamente, consumidores (com os quais se identificam os telespectadores) e o ministro da Fazenda, guardião do real. Do outro lado estão os representantes do comércio a quem se pedem "explicações convincentes" para os preços. A matéria jornalística é construída de modo a criar um inimigo público, enquanto Ricupero é o representante mediático do Plano Real e do Governo. Como qualquer cidadão, "se irrita", "fica escandalizado", mas, com seu poder, também "ameaça" com a abertura das importações, ou, então, "espera contar com a ajuda dos consumidores".

Outra polarização que atua nos enquadramentos é entre o velho e o novo, o ingresso na "era do real", com a entrada em cena do "novo consumidor", o "consumidor-cidadão" na fila do Procon, contra o abuso dos preços. O tempo passa a ser medido de acordo com o calendário político-econômico do real, que estabelece um limite imaginário entre passado e o presente.

Finalmente, a queda da inflação reflete-se num pequeno aumento de compras dos consumidores de baixa renda. O real é denominado uma "moeda forte". É o momento de a câmara de TV mostrar nas lojas imagens euforizantes de pessoas comprando, expressões felizes, como "coisas que as pessoas queriam comprar há muito tempo", "quanrenta ferros (de passar roupa) vendidos só hoje". O enquadramento amplifica o efeito da nova moeda, destacando apenas aspectos positivos, que mostram a perfeição da "nova era". As falas de populares promovem sua identificação com as pessoas comuns, eles são a voz do povo. A fala do gerente da loja parece resumir a ideia principal do enquadramento da matéria jornalística: "uma classe menos favorecida em termos de renda, com a estabilização da moeda, passou a ter acesso ao mercado de consumo". Sem se questionar, a matéria contradiz o apelo à contenção do consumo, feito em outras reportagens.

Nesse crescendo de otimismo, ocorreu o conhecido incidente da divulgação de uma gravação de vídeo em que o ministro Ricupero explicava que sua atuação na TV, na transição das moedas, beneficia- 
va a candidatura de Fernando Henrique. A divulgação da gravação pelos meios, inclusive, no horário eleitoral do PT, provocou um escândalo que confirmava o circuito governo - Globo - Cardoso. Ricupero, exonerado, foi afastado da cena econômico-política, com sua imagem de herói, professor, homem íntegro e honesto arranhada. Porém o enquadramento predominante do plano continuou, sem maiores problemas. O cenário de representação tinha se estabelecido de forma a não ser abalado.

Com o lançamento do Real coincidindo com o início da campanha pelo horário eleitoral gratuito por rádio e TV, a vantagem desfrutada por Lula durante o primeiro semestre de 1994 evaporou logo nas primeiras semanas de agosto, com a reversão espetacular das intenções de voto, que passaram a ser favoráveis a Cardoso. A sociedade tinha aprovado a nova moeda sem inflação e identificou Cardoso como responsável por ela, enquanto Lula parecia representar uma ameaça a sua continuidade. O Plano Real inverteu, em poucas semanas, o cenário de representação da política (CR-P), deslocando Lula para um papel secundário e instalando no centro da cena política o ex-ministro da Fazenda de Itamar Franco, que liderara a equipe responsável pela nova moeda. A inflexão das intenções de voto em Cardoso era irreversível e levariam-no a uma vitória tranquila no primeiro turno, ficando Lula, outra vez, em segundo lugar.

O projeto eleitoral de Cardoso continha um elemento decisivo: na qualidade de ministro da Fazenda, ele tivera condições de construir o cenário de representação da política para sua candidatura, centrada no Plano Real e sua ampla difusão mediática. Os votos não brigam com o cenário.

\section{8: Crise e reeleição}

Como observou Azevedo (in Rubim, 2000, p.36), a eleição de 1998 dá-se num ambiente econômico bastante difícil. Apesar dos quatro anos de estabilidade da moeda, de uma política de privatizações, controle do déficit público, a economia brasileira estava muito 
vulnerável financeiramente. A chamada "âncora cambial" que servira para controlar a inflação cobrava seu preço: o sobrevalorizado artificialmente durante quatro anos, como estratégia para manter a estabilidade alcançada em 1994, gerou um desequilíbrio externo. Azevedo apresenta três indicadores macroeconômicos que se encontravam negativos naquela conjuntura: o crescimento do Produto Interno Bruto, a variação anual da renda média das pessoas ocupadas e o nível de emprego. Para ele, apesar da inflação declinante, os três indicadores revelam que o quadro que se desenhava no ano eleitoral era recessivo, trazendo um potencial de risco eleitoral ao candidato à reeleição.

A estratégia da aliança PSDB-PFL no poder para a eleição de 1998 procurava, ainda uma vez, tirar partido da adesão social ao Plano Real, por meio de uma manobra continuísta, representada pela proposta de emenda estabelecendo a reelegibilidade presidencial no exercício do poder. Nessa empreitada questionável eticamente, por beneficiá-lo pessoalmente, Cardoso contaria, outra vez, com o apoio dos meios de comunicação. Repetia-se a articulação das forças tradicionais, organizadas em torno do PFL, com o PSDB, um partido mais moderno, capaz de arregimentar novos grupos de tecnocratas, a fim de conter a possível ascensão de candidatos do PT, num período crítico. A estratégia continuísta afastaria o risco de vitória de um candidato que substituísse todo o grupo político no poder, possibilidade que assustava também a classe empresarial e parte da classe média, que talvez alimentasse receios de transformações no regime de produção baseado no mercado. Essa última perspectiva amplia a probabilidade das adesões ao projeto reeleitoral conservador, abrindo-o em leque para outros matizes do espectro político e avançando sobre setores centristas. O comunismo acabara, é verdade, não havia mais como invocar sua ameaça, mas as tensões estruturais da sociedade brasileira continuavam.

Baseados em trabalhos de análise que conduzimos, vamos examinar como as questões ligadas às eleições de 1998 foram construídas ou representadas por meio da imprensa; como editoriais, artigos e reportagens do Jornal nacional elaboraram os aspectos políticos, éticos, 
administrativos e doutrinários implicados na votação da emenda da reelegibilidade, a seu favor ou contra ela. Nossa interpretação é de que a reeleição de Cardoso era a pedra de toque de toda a estratégia eleitoral de 1998, por meio do aproveitamento das sobras do Plano Real.

\section{Jornal nacional: a eleição invisível}

Conduzimos, em 1998, uma análise de enquadramento das matérias do Jornal nacional, ${ }^{3}$ fixando-nos em dois pontos de observação: a crise econômica e a campanha eleitoral. Com relação ao primeiro ponto, o JN noticiou a crise, mencionou as implicações para o Brasil, mas o tema recebeu um espaço desproporcionalmente menor do que a importância que tinham os acontecimentos para a economia e a sociedade brasileiras, naquele momento e no futuro. Além disso, as matérias foram fatuais, tratando o assunto de forma não-controvertida e, como diziam respeito às medidas do governo, indiretamente punham em evidência o presidente-candidato, capaz de tomar medidas para o combate à crise. $\mathrm{O}$ foco esteve voltado para as consequências dramáticas da crise em diversos países e no Brasil, nas medidas adotadas pelo governo, nos anúncios do FMI divulgando as notas tranquilizadoras do governo e minimizando o tempo concedido a outras vozes.

O JN, na amostra analisada, acompanhou de maneira muito sucinta os acontecimentos internacionais e as repercussões sobre o Brasil, dedicando pouco tempo às notícias sobre a crise financeira mundial. Em 22 telejornais analisados, houve 15 notícias sobre a crise, com duração média de um minuto e meio, em telejornais que oscilaram em torno de 28 minutos. Em apenas dez notícias mencionou-se o Brasil, usando, em geral, um enquadramento de otimismo, salientando as medidas de Cardoso e de sua equipe econômica.

3 Essa análise contou com a participação da estudante de jornalismo Karenine Miracelli, bolsista do Programa de Apoio ao Estudante, da Pró-Reitoria de Extensão da Unesp. 
Os telejornais do $J N$ adotaram uma narrativa simplificada da crise mundial, que parecia alcançar o Brasil como algo vindo do espaço exterior e sobre cujo impacto ninguém tinha tido qualquer responsabilidade. A crise representada na maior parte dos textos do JN examinados é desprovida de um sentido, algo sem antecedentes, formada por uma série de acontecimentos inesperados, como uma espécie de cataclisma, um flagelo planetário, anistórico. A narrativa do telejornal, dada sua estrutura e sua natureza fatual, não propicia elementos significativamente relevantes a uma representação adequada da vulnerabilidade da economia brasileira, fator que tornava a crise tão grave para o país. Além disso, não foram apresentadas as versões conflitantes que um tema dessa magnitude normalmente suscita.

No que diz respeito às eleições, elas ocuparam um espaço reduzidíssimo no noticiário do $J N$, em pleno período eleitoral, como se não estivessem ocorrendo eleições presidenciais. $\mathrm{O} J N$ renunciou à política e a temas relevantes ligados à eleição. A agenda dos candidatos, recurso utilizado nas eleições anteriores e que se constituía de um espaço reservado em todos os noticiários para apresentar o dia-a-dia dos candidatos, foi totalmente abolida.

Por outro lado, o noticiário do $J N$ ingressou numa fase bem conhecida pela diluição, ampliando o jornalismo de entretenimento que enfatiza curiosidades científicas, tecnológicas e do mundo animal, dramas do dia-a-dia. O JN aproveitou-se desses fatos para preencher a pauta diária, dedicando longos minutos, às vezes até blocos inteiros, a sua cobertura. Miguel (in Rubim, 2004) anotaria essa circunstância, ao contabilizar o elevado percentual de matérias na rubrica "variedades" no JN naquele ano.

\section{A crise econômica nos editoriais}

Com o objetivo de identificar as manifestações do jornalismo opinativo sobre as articulações entre a política econômica e monetária do Brasil e a vulnerabilidade do país à crise econômica de 1998, conduzimos um estudo sobre editoriais da Folha de S. Paulo 
entre agosto e setembro (Soares, 2000). Observamos inicialmente que a FSP procurou mais o debate a respeito dos motivos internos que estariam levando o Brasil a uma situação de crise, e também foi mais dura do que $O$ Estado de $S$. Paulo nas críticas às protelações eleitoreiras da desvalorização do real, mantido artificialmente num patamar elevado como forma de garantir a estabilidade econômica interna. A Folha considerou a desestabilização da moeda brasileira inevitável e defendeu a desvalorização do Real antes de 3 de outubro, data da votação em primeiro turno da eleição presidencial.

Quanto a OESP, as observações revelaram uma adesão incondicional dos editoriais ao receituário neoliberal e apoio às medidas já adotadas pelo governo, como a defesa do real contra a desvalorização cambial, elevação dos juros, diminuição da liquidez, em suma, a "austeridade", com previsões de tempos difíceis e de muito sacrifício popular. Fazendo isso, os editoriais restringiram-se a interpretações de curto alcance da crise, pautando-se por argumentações que desresponsabilizavam as políticas econômicas pela força do impacto da crise mundial.

No entanto, no que respeita ao processo reeleitoral, há uma surpreendente convergência entre os editoriais. Em ambos os jornais, o Brasil aparece ameaçado por um processo de especulação internacional, sofrendo o risco de uma grave crise financeira e cambial que ameaça as conquistas do real. Ambos os jornais apresentaram dados de pesquisas em que Fernando Henrique aparecia como o preferido dos brasileiros, batendo, sem dificuldade, o segundo colocado, Luís Inácio Lula da Silva. Para OESP, quase metade daqueles que votam em Lula não confiam no candidato para comandar o Brasil em crise. Os comentários dos editoriais da FSP e de OESP a respeito da preferência dos eleitores pareciam-se: ambos consideravam o resultado das pesquisas consequência da familiaridade do povo para com o presidente já no poder. Cardoso era considerado o homem apropriado para amortecer os problemas da economia brasileira e para continuar a luta pela manutenção de um real forte. Era ele quem os eleitores queriam no poder, com ou sem inflação: se a moeda funcionava, o presidente era o responsável por isso; se Real não fosse bem, ainda 
assim o presidente precisa continuar, pois era o único capaz de fazêlo voltar a ser o que era. Enquanto isso, Lula era uma incógnita, assim como a sua capacidade para enfrentar os graves problemas econômicos brasileiros daquele momento.

A FSP não considerava honesta a atitude de Cardoso de esperar até as eleições para permitir a desvalorização do real, embora não desaprovasse seu nome para presidente. Para o jornal, a crise revelou um Real fraco e a sua recuperação não aconteceria sem que o Brasil, antes, passasse por terríveis dificuldades nos anos seguintes. Havia, portanto, uma clara inconsistência entre a crítica da política econômica e a avaliação do candidato.

Finalmente, falar sobre a crise econômica nos editoriais da FSP foi, geralmente, um motivo para falar de FHC. O foco na crise econômica dava-se, portanto, em detrimento dos demais candidatos à eleição presidencial, já que as atenções se voltaram mais para as atitudes pontuais do presidente e, ao mesmo tempo, candidato à reeleição e provável futuro presidente. Os editoriais da FSP praticamente não avaliaram o ponto de vista e as propostas dos adversários diante da crise.

No caso de OESP o alinhamento ao presidente-candidato foi mais simples, pois os editoriais sobre a crise e as próprias críticas eventuais ao presidente adotaram uma linha bastante moderada, de modo a deixarem sempre espaço para tecer elogios a FHC, nos quais foram pródigos.

Sumarizando, as reportagens do $J N$ pautaram-se, na maioria das vezes, por enquadramentos que reproduziam as posições dos porta-vozes do governo. Os editoriais de OESP, tipicamente, fizeram coro às medidas adotadas para enfrentar a crise, eventualmente reclamando uma maior austeridade. Por fim, apenas a FSP trouxe interpretações mais elaboradas da conjuntura, fazendo referências críticas à dinâmica assimétrica do sistema global e ao histórico da moeda brasileira e suas inconsistências.

Apesar disso, houve uma convergência de representações favoráveis ao presidente-candidato. A retórica eleitoral hegemônica nas eleições presidenciais de 1998 foi baseada na "competência" e 
"preparação" como condições indispensáveis ao futuro presidente. $\mathrm{O}$ fato de $\mathrm{FHC}$ ser candidato à reeleição favoreceu-o sobremaneira, pois o seu comportamento já era conhecido das pessoas e a sua experiência como presidente, supostamente, recomendava-o para o cargo.

A estratégia reeleitoral, baseada na manutenção da estabilidade do real, não apenas resistiu à crise econômica vivida pelo país, como - paradoxalmente - pode ter se beneficiado com ela. Em 1998, um dos maiores medos difundidos era, ao lado da crise, o do retorno da inflação. FHC apareceu nesse cenário como o mais capacitado para o posto de presidente para uma nova fase da luta para conter a moeda. Se a moeda estável aparecia significativamente colada a FHC em 1994, em 1998 o risco da moeda instável, inesperadamente, agregou uma nova positividade à sua representação, convertendo-o numa quase unanimidade jornalística.

\section{Revista Veja: jornalismo e opinião}

Em 1998, um estudo que fizemos sobre edições da revista Veja de $9,16,23$ e 30 de setembro e de 7 de outubro revelou o direcionamento das reportagens analisadas, correspondentes às últimas semanas de campanha eleitoral, para a construção de um cenário consistentemente favorável a Cardoso (Soares, 2000a). No campo econômico, houve a atribuição da responsabilidade da crise às entidades e potências externas, mundializando o fenômeno e desconectando-o das diretrizes da política econômica do governo. Não houve análise propriamente, pois essa teria que mostrar como a política econômica enfraquecera a economia e as empresas brasileiras. Veja subscreveu a política governamental, limitando-se a lamentar a ocorrência da crise externa, sem questionar a política de sobrevalorização do câmbio e de abertura para as importações que, nos últimos anos, tinham eliminado empregos e tornado a economia brasileira vulnerável ao mercado financeiro mundial. $\mathrm{Na}$ área social, deu-se destaque sistemático a indicadores das melhoras recentes na sociedade brasileira. 
Na parte relativa à atividade política e à campanha eleitoral, a revista destacava efusivamente Fernando Henrique nas reportagens, enquadrando-o de forma positiva e entusiasta, antecipando, de passagem, a derrota de Lula. O campo eleitoral foi, assim, monopolizado pelo candidato oficial, sem o qual, depreende-se das matérias, seria o caos. Em Fernando Henrique só se viam qualidades, resumindo a política brasileira ao pensamento único do presidente.

As reportagens analisadas realizam um enquadramento seletivo, que acentua os pontos favoráveis e omite ou atenua os pontos problemáticos da conjuntura. Temas controvertidos são apresentados como unanimidades, a versão é colocada como o relato consensual, produzindo um texto de despistamento, tornado possível por meio de uma operação discursiva cujo álibi são os pormenores fatuais dos eventos e cuja forma é a de uma narrativa pitoresca.

Os enquadramentos que encontramos nas matérias analisadas adotam uma linha de não questionar o governo, de não incomodar e, sempre que possível, de promover. Essa prática, ao contornar, distorcer e camuflar as circunstâncias efetivas da situação do país, não ofereceu elementos de reflexão e avaliação. No final de 1998, os problemas econômicos agravaram-se, mas as medidas corretivas - como a desvalorização do real - só vieram tardiamente, após as eleições, com Cardoso reconduzido para mais quatro anos de presidência.

No trabalho apresentado na 8 reunião da Compós, em Belo Horizonte, 1999, concluíamos:

Em suma, as representações da conjuntura econômica, da situação social e da atividade política examinadas praticam enquadramentos não-críticos às políticas do governo e ao candidato presidente. Não se exercita um jornalismo de esclarecimento, mas de enaltecimento, de apologia, de otimismo. Trata-se de um jornalismo como função política, que contribui para a instauração de um cenário que exime o candidato-presidente de responsabilidade nos acontecimentos negativos da economia e da sociedade e que salienta os resultados positivos - ou menos insatisfatórios - jamais insistindo nos temas problemáticos da política governamental. (Soares in Rubim, 2000, p.100) 
Azevedo (in Rubim, 2000), citando analistas do processo eleitoral, observou que a campanha pela reeleição minimizou para os mais pobres a dimensão e implicações da crise, enquanto construía para a classe média, na qual estão os leitores de jornais, uma imagem de administrador competente e confrável para Cardoso.

\section{Incertezas na eleição de 2002}

Em 2002, novamente as eleições ocorrem num contexto de crise econômica, expressa pelo rebaixamento do Brasil nas avaliações internacionais de risco, pela alta do dólar, pelo crescimento da dívida pública, pelo acirramento dos problemas sociais (representados emblematicamente pelo aumento do desemprego e da criminalidade), que compuseram de forma dominante as agendas jornalísticas, coincidindo com o período da campanha eleitoral. No entanto, na ausência de um projeto governamental de impacto, como o Plano Real, o cenário instável, desta vez, tornaria o resultado do pleito imprevisível, ao contrário de 1998, quando a vitória de Cardoso se desenhou logo nas primeiras semanas de campanha. Essa instabilidade marcaria também a cobertura da política pelos meios, em particular, a Rede Globo, que tem um papel importante na construção do cenário de representação da política.

O Jornal nacional adotou na eleição presidencial de 2002 uma linha completamente distinta daquela da eleição anterior: ampliou a cobertura jornalística, de modo que as eleições ganharam grande visibilidade na mídia, por meio de reportagens, entrevistas com os candidatos e debates, ao contrário de 1998, quando o noticiário político foi mínimo na Rede Globo. Com base em registros quantitativos, Miguel (in Rubim, 2004) observa que na cobertura realizada em 2002 "o destaque absoluto foi a própria eleição presidencial", que mereceu $29,4 \%$ do tempo do noticiário, em contraste com apenas 4,6\% na eleição de 1998. Segundo sua pesquisa, em comparação com 1998, houve uma completa transformação da postura do Jornal nacional em 2002, caracterizada por longas entrevistas ao vivo com candidatos 
e debates entre os candidatos principais, de modo a mostrar a rede como a verdadeira "regente das eleições". As matérias sobre a "esfera pública" ocupariam a maior parte do tempo no noticiário em 2002, com 44,9\% do tempo (em contraste com 12,9\% na eleição de 1998). Além disso, "em comparação com as eleições anteriores, o noticiário da Rede Globo de fato avançou na direção de um tratamento mais equânime entre os diversos candidatos", havendo uma busca "quase obsessiva pela "imparcialidade"”. Miguel levanta a hipótese de que esse fato se deveu à necessidade da rede de ganhar credibilidade para manter-se dominante no mercado, no momento em que este se abria para o capital estrangeiro. Destaca também a situação financeira difícil das Organizações Globo como outro fator, recomendando cautela com o futuro governo, fosse qual fosse.

Porto e colaboradores, também com base em um estudo que quantificou as observações, concluem que "o tratamento equilibrado das diversas candidaturas parece indicar um esforço consciente dos responsáveis pela produção de notícias no Jornal nacional para superar a parcialidade que, em diversos momentos históricos, caracterizou a cobertura noticiosa da Rede Globo" (in Rubim, 2004, p.87). Da mesma forma que Miguel, os autores citados observam que o telejornal adotaria uma postura isenta nas reportagens sobre os candidatos, bem como dedicaria um tempo equivalente para os principais concorrentes.

No seu trabalho, Porto e seus colegas, da mesma forma que Miguel, observam que mais da metade das matérias do Jornal nacional, entre junho e outubro de 2002, tiveram como tema o processo eleitoral. O segundo tema mais frequente foi a economia, adotando como foco discussões sobre a política econômica. Para o autor, o JN não apenas agendava os temas para a audiência como realizava avaliações sobre causas e responsabilidades, recomendando o que os eleitores deveriam levar em conta ao julgar as propostas dos candidatos.

José Serra, candidato do partido governante, ex-ministro da saúde, estava marcado pela sua ambiguidade: saído do governo, mas crítico das políticas adotadas, era o candidato da continuidade ou da mudança? Apoiado pelo presidente, Serra acabava se asso- 
ciando ao quadro de crise, arcando com o ônus dessa condição, sem dispor de um "plano eleitoral" (como o Plano Real, por exemplo), em condições de constituir um cenário para sua candidatura. Lula, pelo contrário, representava o crítico histórico das políticas governamentais, sendo identificado claramente como alternativa à política do presidente Cardoso, cuidando, ao mesmo tempo, de que sua postura oposicionista não fosse interpretada pelo eleitor como radicalismo. Tendo assinado um manifesto comprometendo-se com a economia de mercado e com a estabilidade, tornava-se impossível reeditar contra ele as restrições convencionais do espectro mais conservador, que tinham funcionado bem nas três eleições anteriores. As debilidades da candidatura do PSDB, em contraste com o candidato do $\mathrm{PT}$, coincidem com o equilíbrio de tratamento da Rede Globo em relação às quatro candidaturas principais (Serra, Lula, Gomes e Garotinho), deixando o resultado do processo entregue às próprias campanhas.

A questão teórica sugerida por essa circunstância inédita nas eleições brasileiras recentes é: como aplicar o conceito de cenário de representação da política (CR-P) na situação da vitória do PT, considerando que os instrumentos da construção desse cenário - a mídia - estão historicamente nas mãos do bloco hegemônico liderado por setores conservadores? Em outras palavras, é possível empregar de modo coerente o conceito em 2002, considerando-se que o resultado do pleito favoreceu o candidato derrotado nas eleições anteriores por não se adequar aos CR-Ps vigentes? Indagado, Venício A. de Lima manifestou-se sobre essa questão:

Creio que as eleições presidenciais de 2002 foram marcadas pela crise financeira dos principais grupos de mídia brasileiros, em particular do grupo hegemônico, as Organizações Globo, agravada a partir da brutal desvalorização do real em relação ao dólar americano nos últimos meses de campanha. Isto fez com que a mídia, em particular o grupo hegemônico, se tornasse vulnerável, ocasionando, aparentemente, uma postura de maior equilíbrio na cobertura jornalística. [...] 
Outro fato importante me parece ter sido a ruptura no Bloco Histórico com a dissensão do PFL após a tentativa frustrada de construir a candidatura de Roseana Sarney. Nesse contexto, creio, o PT articulou uma estratégia de alianças políticas "à direita" e uma estratégia de comunicação - iniciada ainda no período de utilização do tempo dos partidos no RTV - que tinha como objetivo aproximar a imagem de Lula do que C. Geertz chama de "centro ativo da ordem social" ou, em outros termos, do CR-P dominante. Essa estratégia incluiu, com destaque, a neutralização de acusações históricas, fundadas na nossa cultura política autoritária, em relação ao "despreparo" de Lula mostrando-o agora cercado por doutores, altamente qualificados, responsáveis por seu programa de governo. E essa estratégia deu certo. Dessa forma, creio, a vitória de Lula dá-se no quadro da hegemonia dominante - e não de uma proposta contra-hegemônica -, embora ele tenha conseguido conservar seu perfil de oposição ao governo de FHC. ${ }^{4}$

Acreditamos que houve um cenário de representação da política, mas com uma mudança do padrão. Primeiro, o enquadramento do jornalismo da Rede Globo deixou de ser alinhado, adotando critérios estritamente jornalísticos na cobertura do processo eleitoral, o que trouxe a competitividade que faltara nas eleições anteriores. Em segundo lugar, a campanha de Lula criaria as condições para que o candidato se enquadrasse no perfil hegemônico, por meio das alianças eleitorais, da mudança de atitudes, dos compromissos assumidos, dos conteúdos dos programas. O candidato agiu deliberadamente, deslocando sua personagem política em direção ao centro, mantendose, no entanto, como oposição às políticas de FHC e portador das propostas de mudança.

O que a eleição de 2002 sugere é que a configuração particular do CR-P numa dada circunstância histórica parece depender do grau de liberdade de atuação dos profissionais dos meios de comunicação. $\mathrm{Na}$ ausência de regulamentação sobre protocolos do trabalho jornalístico

4 Comentário feito em fevereiro de 2003, em correspondência a este autor. 
em relação a candidatos em eleições, a decisão sobre a conduta dos meios no processo eleitoral será arbitrada pelas corporações e visará exclusivamente aos objetivos estratégicos dessas organizações.

A respeito desse último ponto, é interessante acrescentar algumas observações sobre o papel da Globo em 2002, diante da vitória da coalizão liderada pelo PT e do significado público dessa vitória, assinalado pela efusão de alegria provocada por ela, com o investimento de legitimidade que isso traria para o novo governo. $\mathrm{O}$ tom do novo tempo, como não podia deixar de ser, como observou o jornalista Nelson de Sá, com ironia, foi dado por "ninguém menos que Alexandre Garcia. O velho porta-voz, mais de uma década depois, estava sorrindo". Foi ele quem anunciou a vitória de Lula ao país. Sá continua:

Na sequência, entrou o presidente do Ibope, ele que até ajudava Fernando Collor a escrever seus pronunciamentos, para também anunciar com pompa a vitória do petista. E acrescentar, quase orgulhoso:

- Lula deverá ter entre 55 e 57 milhões de votos e isso o tornará o presidente com mais votos na história mundial. (SÁ, 2002)

A vitória de Lula pareceu trazer, a um só tempo, o fim do estigma de Lula e do PT e o começo de uma nova era, com novos rostos na televisão e nas primeiras páginas. Lula, o presidente da República, eleito por uma votação inédita, apresenta-se como líder de uma aliança de largo espectro político, sereno, negociador, emotivo.

Em vista de sua isenção durante a campanha, a Rede Globo pôde festejar sem constrangimentos a vitória do PT como fato político absolutamente normal, no Fantástico de domingo, após a divulgação do resultado da votação no segundo turno, no Jornal nacional da segunda-feira, dedicado excepcionalmente apenas a entrevistar Lula, encerrando sua efusão com o Globo Repórter da sexta-feira, mostrando mais uma vez a trajetória pessoal do presidente eleito. Com a conversão da rede aos novos tempos, como ocorrera antes, nos anos 1980, no episódio das Diretas-Já, a rede já preparava o caminho 
para obter apoio do futuro governo ao socorro urgente do BNDES para suas premências financeiras.

\section{Reeleição de Lula: a superação do CR-P?}

Considerando a cobertura jornalística, as circunstâncias em que se deu a reeleição de Lula foram bastante adversas a sua candidatura. Organizador de um livro coletivo sobre as eleições de 2006, Lima (2007), na Introdução Geral, num texto que já não emprega mais o conceito de cenário de representação da política, parecendo em busca de outras interpretações, anotou:

O processo eleitoral brasileiro de 2006 será lembrado e estudado, entre outras características, por ter sido aquele em que houve forte desequilíbrio na cobertura jornalística dos principais candidatos à presidência da República, verificado por instituições independentes de pesquisa; por haver prevalecido uma atitude de hostilidade ao candidato Lula entre os jornalistas da grande mídia; por um descolamento entre a opinião dominante na mídia e a opinião da maioria dos eleitores; pelo sensível aumento da importância de sites e blogs no debate eleitoral; pela entrada da mídia na agenda pública de discussão; pela colocação da credibilidade da grande mídia em questão e pela crescente organização da sociedade civil, fenômeno que tem provocado a emergência de uma série de novas mediações que diminuíram o poder de influência direta da grande mídia sobre boa parte dos eleitores. (p.27)

Estudos empíricos independentes dos autores dessa obra apontaram a predominância de matérias jornalísticas desfavoráveis ao candidato do PT, iniciadas em 2005, com a crise do chamado "mensalão", que atingiu seu auge às vésperas da realização do segundo turno, quando se dá a prisão de pessoas ligadas ao PT, com uma alta soma de dinheiro, para a suposta compra de um dossiê que incriminaria o candidato do PSDB (idem). 
Um acompanhamento de cinco jornais (Folha de S. Paulo, O Estado de S. Paulo; Agora, Jornal da tarde e Diário de São Paulo) e de quatro revistas (Veja, Isto é, Época e Carta capital) realizado pelo Observatório Brasileiro de Mídia no período de 6 de julho a 27 de outubro (véspera do segundo turno das eleições) mostrou que as matérias sobre Lula foram predominantemente negativas em todo o período, enquanto os demais candidatos tiveram maior percentual de reportagens positivas, com exceção das da revista Carta capital (Jakobsen in Lima, 2007).

Esses resultados são consistentes com os obtidos pelo acompanhamento feito pela Doxa-Iuperj dos jornais $O$ globo, $O$ Estado de S.Paulo, Folha de S. Paulo, entre primeiro de fevereiro e primeiro de outubro, que levaram os pesquisadores a observarem que em nenhum momento o saldo de noticiário de Lula - presidente e candidato - ultrapassou onze pontos negativos, situando-se, na maior parte do tempo, em torno de trinta por cento negativos para os jornais estudados (Aldé, Mendes, Figueiredo in Lima, 2007).

Outros autores apontaram mesmo uma disposição francamente oligárquica, antipetista e antilulista na cobertura de acontecimentos durante o ano de 2006, predominando entre seus textos a interpretação de que a reeleição de Lula teria significado uma derrota da mídia (Rovai, 2007; Kucinski, 2007; Amorin, 2007; Nassif, 2007 e Coimbra, 2007 in Lima, 2007). Para esses autores, os acontecimentos negativos, especialmente denúncias de casos de corrupção envolvendo integrantes do PT ou do governo Lula, receberam uma atenção desproporcional da mídia ou não foram comprovados, tratando-se, na verdade, de uma campanha contra a reeleição de Lula e favorável a seu adversário Alkmin.

Essa cobertura majoritariamente e fortemente desfavorável, no entanto, aparentemente não exerceu influência ponderável sobre o eleitorado, destacando-se, ao longo das pesquisas, entre 20 de fevereiro e 26 de outubro, a estabilidade das intenções de voto, mantendo a vantagem de Lula sobre Alkmin, seu adversário mais importante, sempre em torno de vinte pontos percentuais (Coimbra in Lima, 2007). Para Coimbra, uma das razões para essa indiferença 
do eleitorado à mídia é a base eleitoral de Lula, construída ao longo de suas candidaturas, que fizeram dele uma personagem com uma longa trajetória, de modo que a maioria dos eleitores de Lula já tinha feito sua escolha muito antes do começo das campanhas. Coimbra argumenta que houve uma mudança do antigo modelo de formação da opinião, que vai dos mais bem informados para as maiorias. $\mathrm{O}$ eleitorado de 2006 é muito diferente daquele de 1989, especialmente porque aumentaram a escolaridade, a informação e a idade, fazendo com que os eleitores chegassem à eleição já posicionados. Para o autor, as eleições de 2006 representaram a "derrota da mídia" no sentido da grande imprensa, que não conseguiu atuar como "formadora de opinião".

O próprio Lima (2007) busca explicações para o sucesso eleitoral de Lula em face da posição dos meios, argumentando com o fortalecimento da sociedade civil, traduzido nos conselhos e conferências municipais, estaduais e nacionais organizados para discutir e propor políticas públicas. Outro ponto diferenciador teriam sido os meios alternativos, como rádios comunitárias e a ação de lideranças, especialmente por meio da internet, agindo em formas organizadas de cidadania. Dessa forma, apesar de ser uma fonte importante de informação, a grande mídia estaria passando, cada vez mais, por mediações das organizações da sociedade civil, num processo que, para o autor, corresponde ao fluxo em duas etapas da comunicação observado por Lazarsfeld, na década de 1940, nos processos de propaganda política. A esse fenômeno eminentemente comunicacional, Lima acrescenta a melhora da qualidade de vida das camadas mais pobres, a ampliação da escolaridade, o aumento da massa salarial e o controle da inflação, fatores que teriam levado ao fortalecimento do que ele denomina de uma consciência cidadã.

Entretanto, outra perspectiva do cenário parece-nos determinante. A reeleição, perseguida por Cardoso, em 1998, que se valeu para obtê-la de todos os meios, até os ilegais, traz consigo um resultado óbvio: numa eleição presidencial, as chances de recondução do candidato no exercício do poder são muito maiores do que a de um dos concorrentes ser eleito. $\mathrm{O}$ presidente-candidato desfruta de 
uma visibilidade pública maior nos meios de comunicação, tem um status social mais alto devido ao cargo, e status pode ser traduzido em termos de vantagens eleitorais, apoios. Além disso, espera-se que experiência administrativa acumulada o torne mais apto a resolver os problemas. Mas, acima de tudo, o presidente-candidato dispõe dos meios administrativos e materiais para lançar as bases de um cenário de representação da política que lhe seja favorável, um cenário no qual ele seja o protagonista por meio de inaugurações, visitas, lançamentos e pronunciamentos divulgados nos telenoticiários da noite. Dessa forma, na eleição de 2006, o PSDB, na oposição, estaria provando do veneno que fabricou em 1998.

O fato de os escândalos envolvendo o PT (a partir de maio de 2005 até a prisão de petistas às vésperas do segundo turno de 2006), amplamente noticiados pela imprensa, rádio, TV e internet, não terem conseguido vencer a candidatura Lula, reeleito, em segundo turno, com cerca de $60 \%$ dos votos, parece uma evidência dessa vantagem do candidato à reeleição.

Além dessa vantagem decorrente de sua condição, Lula protagonizou o processo eleitoral num cenário com dados excepcionalmente favoráveis, que só podiam ser creditados a seu governo: recordes de exportação, inflação sob controle, queda do desemprego, quitação da dívida contraída pelo governo anterior junto ao FMI, diminuição da desigualdade dos mais pobres, autossuficiência petrolífera. A oposição e analistas podiam argumentar que o governo se beneficiara de uma conjuntura internacional favorável, ou que fazia assistencialismo, mas o fato inelutável é que somente Lula podia colher os benefícios eleitorais das melhoras nos indicadores sociais e econômicas ocorridas em seu mandato. Mesmo vitórias que decorriam de ações lançadas em administrações anteriores, como a estabilidade da moeda e a autossuficiência em petróleo, por exemplo, acabaram por beneficiar Lula.

Outro aspecto importante do cenário das eleições de 2006 foram as políticas sociais, que alcançam as maiorias. Durante o primeiro mandato, Lula unificou diversos programas do governo Cardoso destinados às camadas populares, a fim de criar o chamado Bolsa Família, que faz a distribuição anual de cerca de 11 bilhões de reais 
a 8,5 milhões de famílias. Embora de alcance mais restrito, Lula também criou o ProUni, programa por meio do qual jovens pobres puderam frequentar cursos em faculdades particulares gratuitamente ou pagando apenas uma parte das mensalidades, sendo a diferença compensada por meio de isenção fiscal das mantenedoras das escolas. Outras ações governamentais beneficiaram as camadas de menor renda, promovendo uma imagem popular do governo Lula. As políticas sociais e assistenciais de Lula podem ter tido um resultado político semelhante ao do Plano Real, no sentido de que os benefícios dessas políticas capilarizaram um sentimento popular muito favorável a Lula, garantindo apoio das maiorias.

Pela primeira vez, nas cinco campanhas presidenciais de que participou, devido a estar concorrendo à reeleição, Lula, na verdade, podia promover a construção de um cenário adequado para sua personagem política, apesar de não dispor do respaldo dos meios de comunicação de massa convencionais (como ocorrera com seus adversários, anteriormente). A experiência pessoal das melhoras nas condições de vida é um meio simbólico direto, de eficiência máxima. Por sua vez, os eleitores souberam interpretar essas melhoras, identificaram a autoria e a apoiaram, votando. É fácil exarar uma crítica elitista nessa política chamando-a de populista, pois ela é, essencialmente, política, na medida em que é consistente com os interesses dos eleitores que dela se beneficiam.

Se essa análise estiver correta, a vitória eleitoral de Lula em 2006 representa, na verdade, uma confirmação da hipótese do cenário de representação da política, apenas numa perspectiva ampliada que, além das representações mediáticas, da "visibilidade" do candidato-presidente atuando para as câmara, inclui as representações das experiências pessoais significativas do eleitorado em face de políticas públicas.

\section{Considerações finais do capítulo}

Dadas as contradições e desigualdades sociais como o Brasil, as eleições presidenciais têm reacendido demandas sufocadas, fazendo- 
as eclodirem simbolicamente nas campanhas eleitorais. Estratégias de comunicação política, nas três primeiras eleições presidenciais diretas, no período pós-regime militar e pós-Sarney, desviaram a canalização das pressões sociais para postulantes sem vínculos reais com os interesses das classes trabalhadoras. Com isso, as eleições presidenciais diretas foram ganhas por alianças de grupos políticos hegemônicos, marcados pelo apoio do PFL, bloqueando a possibilidade de eleição de candidatos de base popular ou com discursos de mudança das políticas social e econômica. As formas mediáticas que expressaram essa aliança eleitoral foram os cenários de representação da política hegemônicos, construídos pelos meios de comunicação de massa, em particular a Rede Globo, com seu poder de meio oligopolista. Dois procedimentos básicos foram observados para realizar essa construção de cenário pelos meios: o agendamento e o enquadramento dos acontecimentos.

Em 1989, os trabalhos de pesquisa realizados revelaram a predileção expressa da Rede Globo de Televisão e de outros meios em relação ao candidato Fernando Collor de Melo. Nas campanhas de 1994 e de 1998, confirmou-se de forma clássica a previsão de Lima (2001, p.214), feita com base na eleição de 1989, sobre a importância da adequação do candidato ao cenário de representação da política para o sucesso eleitoral. A vitória não dependeu nesses casos exclusivamente das propostas de Cardoso, candidato vencedor, de suas habilidades dramáticas, da qualidade dos programas eleitorais, mas, principalmente, de sua sintonia com o cenário de representação da política construído pelos meios hegemônicos. Em 1994 e 1998, os cenários foram construídos com a participação do candidato Fernando Henrique Cardoso: primeiro com o lançamento da nova moeda, depois com a emenda reeleitoral, e o sentido das campanhas adveio de sua articulação consistente com eles. Em 1994, o cenário foi dominado pela queda da inflação, obtida por Cardoso enquanto ministro da Fazenda. Em 1998, em face do favoritismo inicial de Cardoso, houve o desaparecimento da política no noticiário do $J \mathrm{~N}$ e, diante do quadro de crise apresentada como internacional, a alternativa da reeleição acabou por conferir um sentido positivo ao candidato 
à continuidade, mostrado-o nas campanhas como o mais preparado para enfrentar as ameaças à economia brasileira.

Nas campanhas em que foi derrotado, Lula estivera na contramão dos cenários, em circunstâncias que sinalizavam a adequação do candidato do establishment e a incompatibilidade da personagem do candidato de base popular. Porém, em 2002, diante da incerteza quanto aos candidatos favoritos do eleitorado e da crise dos meios, a construção do cenário de representação da política, conforme os estudos realizados sobre o Jornal nacional, esteve mais "livre", controvertida e menos marcada por enquadramentos inclinados a um ou a outro candidato, de modo que a rede hegemônica não se alinhou a nenhum candidato em particular. Novamente, as crises econômica e social estavam em primeiro plano, mas, dessa vez, em face do desgaste do segundo governo de Cardoso e da neutralidade da Rede Globo, viabilizou-se a retórica de Lula. O candidato do PT representaria uma mudança moderada, aceitando compromissos, de modo a assumir uma posição mais ao centro, neutralizando o antilulismo, com um plano de mudança organizada para o país, apoiado por forças políticas representativas.

Por último, em 2006, além do cenário de realizações com vários resultados positivos, nos campos econômico e social, Lula é beneficiário das vantagens mediáticas e administrativas de disputar a reeleição, podendo desfrutar do apoio das maiorias, a partir de suas realizações no primeiro mandato. Certamente, ele não foi eleito apenas com o voto dos mais pobres, podendo contar também com setores de classe média, mas sua votação mais consistente ocorreu nos estados brasileiros em que a presença do governo foi muito importante para diminuir um pouco as distâncias sociais, em especial nas camadas de menor renda.

O conceito de cenário de representação da política, ao ser formulado nos anos 1990, significa uma abordagem conceitual para tratar a influência mediática nos processos eleitorais. Nas três primeiras eleições, esse cenário esteve muito relacionado com o papel da Rede Globo, a qual, atuando junto aos grupos hegemônicos, detinha o privilégio da construção das agendas e dos quadros de referência 
simbólicos para os eleitores. Em 2002, os diversos estudos realizados mostram de forma inequívoca que não se deu uma intervenção orquestrada da rede na construção do cenário, de modo que é preciso enfocar o conceito de forma relativizada. Diferentemente dos pleitos anteriores, parece-nos que o CR-P em 2002 não esteve ajustado de antemão às peculiaridades de uma candidatura em particular, mas resultou de critérios jornalísticos profissionais, e a eleição de Lula dependeu do fato de sua campanha ter se adequado melhor a esse CR-P do que as demais. Portanto a aplicação do conceito, em 2002, precisaria ser feita numa chave diferente daquela das eleições anteriores, porque as circunstâncias históricas mudaram de maneira importante. A ação mais equilibrada da rede teve como resultado um CR-P formulado de maneira mais problemática, controvertida e ambígua, por meio de representações com um gradiente de tonalidades ampliado. Resultado dessa circunstância, sem dúvida, foi a intensificação da luta política, expressa no fato de ter havido dois turnos e disputa eleitoral efetiva.

Já na eleição de 2006, consideramos que o conceito de CR-P ainda é apropriado, que Lula participa da sua construção, dessa vez em uma posição de vantagem por estar no poder. Nessa condição, ele não só foi o beneficiário de uma série de indicadores econômicos melhores, como também estabeleceu políticas que fortaleceram sua ligação com setores de menor renda, as quais também poderiam ser entendidas como meios alternativos de comunicação, capazes de construir cenários de representação da política para essas camadas.

\section{Referências bibliográficas}

AGUIAR, C. B. de. Imprensa e eleições 1989: razão e sedução na opinião das elites. São Paulo, 1993, 340p. Tese (Doutorado em Ciências da Comunicação) - Escola de Comunicações e Artes, Universidade de São Paulo. BIROLI, F. M. A cobertura das eleições presidenciais de 1994 pelo Jornal Nacional da Rede Globo. Bauru, 1995, 87p. Pesquisa de iniciação científica financiada pelo PIBIC/CNPq. Faculdade de Arquitetura, Artes e Comunicação, Universidade Estadual Paulista. (Mimeogr.) 
FOLHA DE S. PAULO As razões do voto e da rejeição. 5 jun.1994, p.1-8. FHC está 24 pontos à frente de Lula, cresce chance de vitória no 1o. turno. 18 set. 1994, Supereleição - Especial, p.1.

LIMA, V. A. de. Televisão e poder: a hipótese do cenário de representação da política, CR-P. Comunicação E Política, Nova Série, v.1, n.1, p 5-22, ago./nov.1994.

CR-P: novos aspectos teóricos e implicações para a análise política. Comunicação Ė política, nova série, v.1, n.3, p 95-106, abr./jul. 1995. Os midia e o cenário de representação da política. Lua nova, São Paulo, n.38, p.239-71, 1996.

Mídia, teoria e política. São Paulo: Fundação Perseu Abramo, 2001. The state, television and political power in Brasil. Comunicação e política. Rio de Janeiro, n.9, 1989. p.159-83.

MIGUEL, L. F. A descoberta da política - a campanha de 2002 na Rede Globo. In:

MISSIKA, J. L., BREGMAN, D. On framing the campaign, mass media roles in negotiatin the meaning of the vote. European Journal of Communication, v.2, n.3, p.289-309, sep.1987.

PORTO, M., VASCONCELOS, R. F., BASTOS, B. B. A televisão e o primeiro turno das eleições presidenciais de 2002: análise do Jornal nacional e do horário eleitoral. In: RUBIN, A. A. C. (Org.) Eleições presidenciais em 2002 no Brasil. São Paulo, Hacker: 2004. p.68-90.

Mídia e eleições 98. Salvador: Editora Universitária Facom/UFBA, 2000. 2004.

ROBINSON, J. L., CHARRON, G-Y. Television news and the public sphere, the case of the Québec referéndum. In: RABOY, M., BRUCK, P. (Eds.) Communication for and against democracy. Montreal-Nova Iorque, Black Rose Books: 1989. p.147-82.

. (Org.) Mídia e eleições de 1998. Salvador: Ed. Universitária/ UFPB,Facom/UFBA, 2000.

SÁ, N.de. Nova velha história. Folha de S. Paulo, Folha Brasil, No Ar. 28/10/2002.

SOARES, M. C. Construindo o significado do voto, retórica da propaganda política pela televisão. São Paulo, 1995. 387p. Tese(Doutorado)-Escola de Comunicações e Artes, Universidade de São Paulo.

Percepções e critérios dos eleitores na campanha eleitoral de 1994. (Trabalho apresentado no GT de Comunicação e Política do IV Encon- 
tro da Associação Nacional de Pós-Graduação em Comunicação Social, Brasília, 1995). Unesp, 1995. 12p. (Mimeogr.).

Lula na TV: aspectos e limitações da retórica eleitoral do PT. CDrom do $11^{\circ}$. Encontro Anual da Associação Nacional dos Programas de Pós-Graduação em Comunicação - COMPÓS. Rio de Janeiro, ECO-UFRJ: 2002.

Os significados do voto. (Trabalho apresentado no GT de Comunicaçào e Política do V Encontro da Compós, São Paulo, maio de 1996) Unesp, 1995, 12 p.(Mimeogr.).

Jornalismo, crise e eleições presidenciais no Brasil. In: ENCONTRO DA ASSOCIAÇÃO NACIONAL DE PÓS-GRADUAÇÃO EM COMUNICAÇÃO - COMPÓS, 9., 2000, Porto Alegre. Anais... Porto Alegre: COMPÓS/FAMECOS-PUCRS, 2000. 1 CD-ROM.

Veja e a construção do CR-P nas eleições presidenciais de 1998. In: RUBIM. A. A. C. (Org.). Mídia e eleições 98. Salvador: Editora Universitária Facom/UFBA, 2000a. p.89-102.

Percepções e critérios dos eleitores na campanha eleitoral de 1994. (Trabalho apresentado no GT de Comunicação e Política do IV Encontro da Associação Nacional de Pós-Graduação em Comunicação Social, Brasília, 1995). Unesp, 1995. 12 p.(Mimeogr.). 



\section{8 \\ REPRESENTAÇÕES DA REELEIÇÃO PELA IMPRENSA ${ }^{1}$}

\section{Introdução}

Esta análise pretende examinar alguns aspectos do processo pelo qual a imprensa participou da elaboração do cenário de representação da política brasileira, tanto pelo prisma da hegemonia como da resistência a ela, ao estabelecer representações sobre a votação da emenda da reelegibilidade pelo Congresso Nacional. Examinaremos, em uma primeira aproximação, as posições dos jornais $O$ Estado de $S$. Paulo e Folha de S. Paulo, expressas em editoriais e artigos de colaboradores, nos espaços abertos para a controvérsia.

\section{Preliminar: eleições e demandas sociais}

Num país com tamanhas contradições e desigualdades sociais como o Brasil, as eleições presidenciais têm reacendido demandas vitais sufocadas, fazendo-as eclodirem simbolicamente nas campa-

1 Trabalho apresentado noVII Encontro da Associação Nacional de Pós-Graduação em Comunicação (Compós), 1998, em São Paulo. Colaborou na preparação deste texto a estudante de jornalismo e bolsista do Pibic Walkiria Vieira. O autor agradece as sugestões metodológicas feitas pelo Dr. Afonso de Albuquerque. 
nhas eleitorais. Como não seria possível atender as reivindicações populares mantendo o status quo, no Brasil pós-regime militar e pós-Sarney, os setores conservadores utilizaram expedientes extraordinários de comunicação política, nas duas eleições presidenciais diretas, com vistas a desviar a canalização das pressões sociais dos partidos de esquerda, especialmente das frentes lideradas pelo PT. Com isso, as eleições presidenciais diretas foram se tornando operações planejadas com bastante antecedência por uma aliança entre grupos conservadores e tecnocratas, visando bloquear a possibilidade de eleição de um candidato comprometido com as maiorias.

Na conjuntura pré-eleitoral de 1994, Lula representava, desde o início, o papel de candidato das maiorias, desfrutando de uma situação excepcional nas prévias, sendo, no entanto, surpreendido, a partir de agosto, pela impressionante virada do eleitorado em direção ao candidato Fernando Henrique Cardoso, em virtude Plano Real, planejado por este último enquanto ministro. O plano, cuja etapa crucial de implantação coincidia com o início da campanha eleitoral, obteve tamanho sucesso que, comparada a ele, a empreitada collorista de 1989 parecia ter sido uma improvisação de amadores. O Plano Real reverteu, em poucas semanas, o cenário de representação da política (CR-P), deslocando Lula para um papel secundário e instalando no centro do drama político o ex-ministro da Fazenda de Itamar Franco, que liderara a equipe responsável pelo Real.

O pressuposto deste capítulo é que a conhecida adesão social ao Plano Real serve de base para a legitimação da próxima estratégia das elites, com o concurso dos meios de comunicação. Mais uma vez, realiza-se uma articulação das forças conservadoras tradicionais com novos grupos de tecnocratas, de maneira a estabelecer uma estratégia capaz de conter uma possível ascensão das reivindicações populares, conduzida por candidatos dos partidos de esquerda, num período crítico, marcado agora pelas altas taxas de desemprego. Dessa vez o estratagema conservador é representado pela proposta de emenda estabelecendo a reelegibilidade presidencial no exercício do poder, cujo beneficiário é o presidente Fernando Henrique Cardoso, identificado com a estabilidade monetária. O objetivo que anima essa estratégia 
continuísta é afastar o risco de vitória de um candidato que substitua não apenas o atual presidente, mas todo o grupo político no poder desde o fim do regime militar, possibilidade que assusta também as categorias sociais plenamente inseridas na economia de mercado. Essa última perspectiva amplia a probabilidade das adesões ao projeto reeleitoral conservador, abrindo-o em leque para outros matizes do espectro político e avançando sobre setores centristas. $\mathrm{O}$ comunismo acabou, não há mais como invocar sua ameaça, mas as tensões estruturais da sociedade brasileira continuam e é preciso administrá-las.

Embora parta dessa hipótese, o artigo não tem, no entanto, a pretensão de verificá-la diretamente, limitando-se apenas, com um objetivo semelhante ao capítulo anterior, a examinar se e como essas questões foram constituídas ou alternativamente representadas por meio da imprensa, como editoriais e artigos elaboraram os aspectos políticos, éticos, administrativos, doutrinários implicados na votação da emenda da reelegibilidade, a seu favor ou contra ela.

\section{A reeleição na imprensa}

O embate reeleitoral trava-se, também, pela imprensa. ${ }^{2}$ E é ela que dispõe o cenário e os atores, distribui a palavra, elege ou confirma temas para a discussão pública da política, contribuindo para a construção da própria ideia de política e de eleições, bem como de tudo o mais que seja pertinente e significativo para o país (Aguiar, 1993). A imprensa articula os significados dos fatos, constituindo o lugar por excelência no qual as sociedades elaboram simbolicamente a realidade, conferindo-lhe sentidos. Assim, também a emenda pela reelegibilidade presidencial implica um processo de elaboração de significados, por meio dos discursos dos jornais.

Mas, como adverte Aguiar, devido à maneira como se estrutura o poder dos meios no Brasil, o terreno da comunicação de massa,

2 Naturalmente, o papel da imprensa nesse episódio é limitado à discussão da legitimidade da emenda, uma vez que a sua aprovação seria restrita ao Legislativo. 
embora decisivo no contexto da ampliação da democracia, afigurase problemático, pois a imprensa nem sempre esteve comprometida com o avanço democrático.

No mês de janeiro de 1997, quando foi votada a emenda da reelegibilidade, o tema frequentou a imprensa diária. Nosso ensaio examina os editoriais dos jornais $O$ Estado de S. Paulo (OESP) e Folha de S. Paulo (FSP) e artigos de colaboradores publicados por esses dois periódicos. Editoriais e colaborações obedecem a lógicas comunicativas muito distintas: enquanto o discurso dos editoriais é institucional, o das colunas é individual. Editoriais podem compor um índice da orientação dos interesses dos grupos dirigentes das publicações, enquanto os artigos refletem um pouco do que se discute nos meios partidários, sindicais, empresariais e intelectuais. $\mathrm{O}$ jornal frequentemente constitui-se num palco de visões conflitantes, as quais, em última análise, concorrem para compor representações dos acontecimentos, legitimando-os ou deslegitimando-os.

\section{As posições dos jornais, com base nos editoriais}

No período de discussão e votação da emenda da reeleição, os editoriais de ambos os jornais estudados formularam sempre representações favoráveis à sua aprovação, empregando, entretanto, uma limitada argumentação. Faremos, em seguida, um resumo das principais ideias defendidas pelos editoriais ao longo do período de discussão e votação da emenda.

Os editoriais de OESP foram categóricos no apoio à emenda, em afirmações como: “... a vontade majoritária do país quer adotar o instituto da reelegibilidade" e "O presidente tem qualidades de sobra para conduzir um plano econômico sério como o Real. Não lhe faltam condições para determinar as diretrizes políticas e econômicas..." (Fumaça sem fogo na convenção do PMDB, de 14 de janeiro).

OESP considera positiva a proposta de um plebiscito sobre a emenda da reeleição, pois este reduziria os poderes do Congresso, colocando, automaticamente, a decisão nas mãos do povo, mas aca- 
ba dizendo que um plebiscito é desnecessário, pois tomaria tempo demais para uma decisão, num país ávido por soluções, ironizando que hoje nem a oposição luta pela consulta popular, diante das manifestações populares favoráveis à reeleição de FHC. Reafirma a necessidade da continuidade do presidente no cargo, para levar adiante o Plano Real e o Programa de Modernização, uma vez que o cenário eleitoral não aponta ninguém à altura dele.

OESP critica a artificialidade da crise que setores do PMDB quiseram abrir com o governo, dado o empenho do deputado Michel Temer em assumir a Presidência da Câmara dos Deputados e do senador Íris Resende em conquistar a Presidência do Senado. Ambos, para disputar os postos almejados, usam manobras para adiar a votação da emenda da reeleição. Para o editorialista, o que existe é a rebelião de alguns senadores do $\mathrm{PMDB}$, que não querem romper com o Palácio do Planalto, mas desejam garantias de que seu projeto de poder será respaldado pelo governo.

O jornal diz que "o chefe do governo teria motivos de sobra para, na metade de seu mandato, dar-se por satifeito com a obra já realizada." (Mudando a fisionomia do país, de 21 de janeiro). O Plano Real é considerado uma obra coletiva, mas sem a direção de FHC não teria sido posta em prática, viabilizando a mudança do país.

OESP aborda a morosidade com que tem caminhado a votação da emenda da reeleição. Não por falta de interesse, mas, pelo contrário, exatamente pela existência de diversos interesses em jogo, o andamento da votação tem sido lento. Michel Temer e Íris Resende atravancam a tramitação da emenda para garantir o apoio a suas pretensões. Outros tantos deputados só aceitam votar a favor da emenda em troca de algum cargo, configurando a barganha. Diante disso, FHC é quem acaba perdendo sua popularidade diante de tantos episódios desgastantes, que param o país e as reformas urgentes.

O jornal considera que as comemorações pela vitória do presidente na primeira votação da emenda da reeleição têm sua razão de ser, porque o primeiro turno acaba se repetindo nas demais votações. E almeja: "Oxalá seja assim..." A imagem desgastada do presidente resulta da necessidade que teve de intervir nas negociações, em 
função do comportamento de parlamentares que o obrigaram a tal procedimento. A paralisação da administração também se deve à necessidade de intervenção de FHC, que precisou concentrar sua atenção num único tema durante semanas, sendo conduzido pelo comportamento de parlamentares. Relaciona as qualidades de FHC e enaltece sua capacidade de governar o país, dizendo ser ele, no momento, o único em condições de ocupar o cargo, já que é o “... presidente mais bem preparado, intelectual e politicamente, que o Brasil teve nas últimas décadas..." "Ninguém é mais capaz que o presidente FHC de levar avante a modernização da economia e das instituições..." (Apenas uma etapa vencida, de 30 de janeiro). Considera ainda a reeleição positiva, indicadora de estabilidade, geradora de investimentos externos, sendo que os únicos prejudicados são os opositores de FHC, que perderam a chance de disputar a presidência sem Fernando Henrique no páreo.

Para OESP, a reeleição é desejada pela população para que "a obra apenas iniciada seja levada adiante por quem tem as melhores condições possíveis de completá-la com pleno êxito" (Uma questão de empenho, de 2 de fevereiro).

$\mathrm{O}$ apoio à reelegibilidade marca igualmente os editoriais da Folha de S. Paulo, mas neste jornal a posição aparece matizada por diversas restrições sobre a forma de encaminhamento. Assim, o jornal enfatiza a necessidade de um plebiscito para que a população participe deste momento político ativamente e não como um "convidado de pedra", assistindo a tomada de decisões estático, sem nada poder fazer. Menciona as pressões a que FHC tem sido submetido pelo PMDB, por exemplo. A forma como foi conduzida a proposta da reeleição implicou barganha e casuísmo, enquanto reformas necessárias aos interesses do eleitorado são deixadas de lado. A reeleição acabou por subordinar-se a "interesses mesquinhos, egoísmos provincianos e caudilhismos rançosos", caindo num "vergonhoso festival de "negociações"', quando decisões importantes deveriam ser tomadas com seriedade (Dois, quatro ou seis, de 16 de janeiro).

Compra de votos, do dia 17 de janeiro, volta a enfatizar a necessidade de realização de um plebiscito, ouvindo a chamada "voz 
rouca das ruas", para que a decisão acerca da emenda da reeleição seja legitimada pelo eleitorado e não no plenário da Câmara Federal, como está programado. O mundo político e administrativo parou, os agentes econômicos estão apreensivos e discussões de maior relevância foram enterradas, tudo em função da obsessão por um único tema, a reeleição. Insiste em que a votação da emenda tem provocado barganha e pressões sobre o presidente, por parte do PMDB, ansioso pela Presidência da Câmara e do Senado. Todos os adiamentos da votação têm como motivo reivindicações pessoais e partidárias, as quais tendem a manchar a tese da reeleição. Embora defenda esta última, o jornal frisa a necessidade de um plebiscito, mediante o qual diversos episódios, como o escândalo da compra de votos, não teriam ocorrido, evitando todo o desgaste pelo qual tem passado o governo.

A FSP aborda como deputados federais, senadores e o próprio presidente se empenharam de forma singular e jamais observada antes, em nenhum outro projeto, em ver aprovada a emenda da reeleição. Enquanto isso, reformas de importância superior são postas de lado, como a reforma política, a previdenciária, a tributária e a administrativa. Favorável à emenda que garante o direito à reeleição, inclusive para os atuais mandatários, a FSP considera inaceitável e altamente inconveniente para o país todas as atenções se concentrarem num único tema.

O jornal alerta sobre o quanto seria prejudicial o afastamento do governante do cargo ocupado para se recandidatar. O argumento é de que a renúncia do governante prejudicaria o caráter de continuidade administrativa, refutando a ideia de que a máquina do governo poderia ser utilizada, desde que haja fiscalização da sociedade. Afirma que "vencer um pleito estando no poder pode não ser tão fácil" (Sair para quê, de 31 de janeiro).

Para a FSP, as manobras da oposição, sobretudo as realizadas pelo $\mathrm{PMDB}$, na convenção do partido que recomendou que seus integrantes votassem contra a aprovação da emenda, enfraquecem os partidos e em nada beneficiam o país. Com a aprovação da emenda, FHC sai fortalecido e bem que poderia apresentar diferentes caminhos para a economia, saúde e educação. Mas a maioria dos parlamentares que 
votaram pela reelegibilidade não representam apoio a FHC, que precisa barganhar para que seus projetos sejam aprovados.

A convocação extraordinária, realizada, teoricamente, para a votação de uma série de projetos importantes, na prática trouxe resultados muito distantes do desejado. Poucos projetos foram discutidos, enquanto toda a atenção se voltava para a votação da reeleição dos mandatários do Executivo. O jornal manifesta sua indignação com o Legislativo, por conferir tamanha atenção e açodamento à emenda da reeleição, enquanto diversas reformas permencem estagnadas em função da morosidade parlamentar.

\section{Argumentos dos artigos de colaboradores}

Vamos examinar, agora, os artigos de colaboradores externos aos quadros dos dois jornais, começando por aqueles que desenvolveram a defesa da aprovação da emenda reeleitoral. NesSe caso, observamos com surpresa que $O$ Estado de $S$. Paulo não trouxe nenhum texto de colaborador favorável à reelegibilidade, enquanto a Folha trouxe alguns artigos favoráveis. Assim, em Reeleição e consulta nacional, publicado em 15 de janeiro, Franco Montoro alega que a reelegibilidade assegura a continuidade de programas de governo que receberam apoio da população, além de ser uma norma aconselhada pelo bom-senso e pela experiência internacional.

André Lara Resende diz, em Riscos, no dia 21, que ideal seria a aprovação da emenda, para não enfraquecer o governo, nem paralisar o seu projeto. Ele critica a morosidade das discussões, apoiando a reeleição, que seria a forma do governo continuar seu trabalho por mais quatro anos.

Carlos Eduardo Moreira Ferreira, presidente da Fiesp/Ciesp, declarando-se favorável à reeleição, tal como os empresários, escreve em Decisão já, de 21 de janeiro, que há necessidade de tomar a decisão rapidamente, porque o tema, ao monopolizar a agenda nacional, paralisa o andamento das reformas, constituindo um obstáculo ao crescimento econômico e à competição no mercado globalizado. 
Gerardo Mello Mourão, em A ética e a reeleição, publicada no dia 23, escreve que no Estado democrático, a ética está aberta ao ecletismo das circunstâncias: a coisa pública não é problema de ética, o Estado é aético. Assim, a emenda não pode ser acusada por esSe aspecto, nem mesmo Fernando Henrique Cardoso desonrou a ética - atributo da pessoa civil dos governantes - ao tentar derrubar a cláusula constitucional que impede a reeleição, mesmo que para seu próprio usufruto.

José Sarney (que no dia 17 fora contra a emenda), em $O$ povo ou a capoeira, de 24 de janeiro, considera que quatro anos são insuficientes, sendo favorável à possibilidade de um governante ser reeleito. A divergência dá-se quanto à forma como vem sendo conduzida, acreditando ser necessário um referendo ou plebiscito para que o povo, como prevê a Constituição, possa decidir.

O senador do PFL, Élcio Álvares, do ES, em A recandidatura de FHC, do dia 27, defende que FHC não está legislando em causa própria, uma vez que sua candidatura só será decidida em 1998. A reeleição é importante por permitir que um governante dê continuidade ao seu plano de governo, pois dispõe de tempo curto - 4 anos - para fazer reformas que o país espera há décadas. Além do mais, trata-se de prática adotada no mundo moderno e a FHC deve ser dado o direito de uma recandidatura, possibilitando a continuidade do programa de governo (reforma do Estado, privatizações, reforma agrária).

Ernando Uchoa Lima, presidente da OAB, em Reeleição com plebiscito, de 27 de janeiro, mostra-se favorável à emenda, porque ela tornaria possível a continuidade de administrações honradas. Porém, defende a realização de um plebiscito, como forma de exercício democrático e legitimador da proposta a ser aprovada. Independentemente dessa etapa, a possibilidade de um candidato ser eleito ou reeleito está intrinsecamente associada a sua conduta, de forma que o povo não concederia novo mandato àquele que realizou um mau governo, o que põe fim ao risco de ressurgimento de oligarquias regionais.

Luiz Gonzaga Mota, com Reeleição e plebiscito, do dia 28 de janeiro, defende que a possibilidade de reeleição é parte de um regime democrático, consistindo numa ampliação dos direitos de escolha 
do cidadão. Um bom governante, depois de um mandato curto mas bem realizado, deveria ter a oportunidade, de acordo com a vontade do povo, de dar continuidade ao seu programa.

Miguel Reale Jr. argumenta, em Reeleição no exercício do poder, de 2 de fevereiro, que não haveria necessidade de desincompatibilização, ou seja, o candidato não necessitaria renunciar para concorrer ao pleito. Além do mais, a desincompatibilização criaria um hiato de meses, tornando inócua a pretensão de proteger a continuidade da administração a ser mantida.

Os articulistas contrários à reeleição distribuíram-se por um espectro político mais amplo, utilizaram uma variedade maior de argumentos e foram mais normativos do que pragmáticos. Vejamos as suas posições críticas, começando por aquelas saídas no OESP.

Fernando Abrucio e Marco Antonio Teixeira em São Paulo e o ano político de 1997, de 15 de janeiro, observam que a reeleição é um casuísmo e que o ano de 1997 se caracteriza como um período de apostas, investimentos e lapidação, tendo como objetivo as disputas eleitorais de 1998, sendo, portanto, uma época de plantio das sementes para o ano seguinte, quando os frutos serão colhidos.

Paulo Rabello de Castro, em artigo de 26 de janeiro, critica o fato de as necessidades do país serem postas de lado em função dos interesses daqueles que ocupam o poder e acabam legislando em causa própria, ao defenderem medidas em que são os grandes beneficiados.

Luiz Weis, em O preço da consulta, de 27, trata da participação popular nas grandes decisões, por meio de plebiscito. A democracia direta é a promotora da cidadania, formadora de bons cidadãos e, numa época de

desgosto universal com os políticos, certas decisões são importantes demais para ficarem nas mãos destes últimos. Principalmente aquelas com maior valor de barganha, por meio das quais se corrompe a consciência de um deputado com favores, cargos ou dinheiro vivo.

Gaudêncio Torquato, em PMDB, entre a cruz e a espada, aborda, no dia 27, a incoerência dos partidos perante seus antigos ideais, em 
especial o PMDB, símbolo da luta contra a ditadura e cujo líder, hoje, tem como meta aprovar a emenda por 60 peemedebistas, em troca do apoio do PSDB e do PTB à sua eleição à Presidência da Câmara.

Jarbas Passarinho ( $O$ costume de mudar, de 28 de janeiro) critica a reeleição, por ser uma revogação de leis que fere a Constituição, implicando a adoção de uma instituição proibida desde a instauração da República. A modificação da lei gira em torno do interesse de Fernando Henrique Cardoso em reeleger-se, utilizando-se dos meios de comunicação em busca do apoio da opinião pública, enquanto conquista votos favoráveis concedendo verbas.

Na FSP também houve um bom número de artigos de colaboradores contrários à reeleição. José Sarney escreve que o único assunto em pauta em Brasília é a reeleição, usando a mídia como base de seus argumentos.

Hélio Bicudo (Reeleição, plebiscito e referendo, de 13 de janeiro) considera perda de tempo a discussão em torno da reeleição, a qual não contribui para o aperfeiçoamento da democracia. A reeleição no contexto da cultura brasileira acaba beneficiando candidatos oficiais por meio do uso da máquina administrativa.

Aldo Rabelo (Candidato a caudilho, de 14 de janeiro) critica a reeleição por ferir uma norma constitucional e a própria democracia, uma vez que são grandes as possibilidades de manipulação eleitoral por um candidato no cargo: "Uma manobra continuísta está sendo ensaiada por Fujimori no Peru e Menem, na Argentina e agora é realizada por FHC, como se ele fosse insubstituível, o único com condições de defender e implementar os direitos da maioria”. Considera o procedimento de FHC mal-intencionado e centrado em ambições pessoais, deixando de lado outros projetos de urgência para a nação, como a reforma administrativa e a reforma agrária.

Roberto Requião (Ai de ti, PMDB, de 16 de janeiro) diz que a base do PMDB é contrária à emenda da reeleição, e que FHC se julga o único, o iluminado, o eleito, criticando suas estratégias de barganha para atingir seus objetivos.

José Sarney, em Da popularidade, de 17 de janeiro, trata da popularidade que cerca os políticos, e a forma como são seduzidos por ela. 
Administrá-la não é considerada tarefa fácil, porém, numa sociedade institucionalizada e democrática, pode-se negociar e atingir um consenso. Referindo-se a FHC, considera-o um presidente do diálogo e da conveniência e por isso sua atitude pró-reeleição é apelativa e desnecessária. Conclui, em contraposição: "vamos marchar para decidir no corpo-a-corpo no Congresso, mas sobretudo nas ruas. Vamos quebrar o PMDB ao meio". Encerra com um provérbio nordestino - "Com grito não se afina rabeca" - para condenar a atitude de FHC.

Emir Sader (Pyongyang é aqui, de 17 de janeiro) chama a enxurrada de manipulações com que o governo entulhou a grande imprensa no final de 96 de "êxtase estatístico": a exposição de dados surrealistas, jamais obtidos por nenhum país na História, emitidos pelo presidente, tem explicação na pensée unique, ou seja, o presidente só pensa em um assunto, a reeleição, e legisla em torno dessa causa. A reeleição serve para que o presidente deixe de lado o que já foi um de suas bandeiras - a reforma política -, bem como o debate sobre a democracia, a saúde, a previdência social, realizando discursos como se vivêssemos num paraíso.

Delfim Neto, em A reeleição e o óleo de cobra, de 22 de janeiro, compara a proposta de reeleição aos óleos de cobra dos filmes do velho Oeste, os quais curavam desde unha encravada até nó nas tripas: "Hoje, o que está sendo oferecido à sociedade no lugar do óleo é a reeleição, a qual daria a FHC oportunidade de dar continuidade ao seu programa de governo. Só assim, por meio da aprovação da emenda da reeleição, FHC poderia continuar no poder e dar soluções aos problemas da nação, principalmente os de ordem econômica, uma vez que o programa de combate à inflação, construído pelos economistas do governo, destruiu o setor produtivo, numa verdadeira armadilha que só eles podem desmontar". Daí a necessidade de mais quatro anos no poder, ironiza.

Almino Affonso (Reeleição e plebiscito, de 22 de janeiro) opõe-se à aprovação da emenda porque ela "cria normas incompatíveis com o nível de nosso desenvolvimento democrático", além de ser um risco, pois, "no futuro, o que faremos se algum malandro ressurgido assumir o poder?" E se cortes familiares se impuserem, por meio da 
possibilidade de candidaturas de parentes, em concomitância com a reeleição do presidente, do governador, do prefeito?

Herbert de Souza (Reeleição e os dinossauros, de 28 de janeiro) diz que o tema da reeleição é parte dos interesses e objetivos de FHC e este se utiliza de argumentos jurássicos para defendê-la, como a não necessidade de mudar, mediante a funcionalidade de seu governo, a moeda forte, a estabilização, como se regesse uma orquestra e o povo somente assistisse ao espetáculo. Enquanto a reeleição se torna uma novela, as reformas são deixadas de lado, em detrimento de uma agenda nacional que passa a inexistir. Esse procedimento fere a democracia, pois induz a uma personalização do poder que, erroneamente, concede caráter pessoal ao governo, o qual, na realidade, deveria ser programático e partidário.

José Dirceu, em A responsabilidade histórica de FHC, de 29 de janeiro, indaga como seria a situação do país, caso o presidente e aliados se dedicassem à reforma agrária, à saúde, à educação, ao fim da corrupção, do fisiologismo e à violência nas cidades com o mesmo empenho que tem sido aplicado à aprovação da emenda da reeleição. Em busca de oito anos de mandato, FHC caminha rumo ao autoritarismo, como um déspota pretensioso a conduzir o Brasil nos próximos vinte anos. E a pressa em aprovar a emenda via Congresso, sem a passagem pela consulta popular por plebiscito, se deve ao fato de FHC ter aversão ao conflito e também porque enfrentar a oposição desgastaria o governo. Além disso, a economia não é tão segura como anuncia a propaganda governista. A estabilidade brasileira é, na verdade, frágil e o "paraíso cantado em verso e prosa pela mídia é pura ficção". Trata-se de uma armadilha como outras que já dominaram o país, como a ditadura, o "milagre" e Collor, que só enganaram o povo.

José Sarney (que no dia 24 fora favorável à emenda) retorna em 31 de janeiro, com A ressaca da vitória, para alertar que a vitória do governo precisa ser administrada, pois implica em cobranças. Recorda Alexis de Tocqueville, que afirmava que a gande vulnerabilidade da reeleição é o fato de os governantes já assumirem seus mandatos pensando nela e transformarem seu governo em instrumento desse desejo. 
Em $O$ avesso do avesso, de 2 de fevereiro, Emir Sader discorre sobre os procedimentos utilizados durante a discussão em torno do tema da reeleição, até sua aprovação, os quais acabaram por contrariar critérios da ética de princípios e da responsabilidade. Em nome da aprovação da emenda, deixaram-se de lado princípios cruciais, como o fortalecimento dos partidos, fidelidade partidária, debate político, reforma da representação dos estados no Congresso, para colocar em prática táticas que vinham ao encontro dos interesses daqueles que se encontravam no balcão de negócios. Assim, entraram em vigor a personalização do poder, uma campanha frenética de desobediência no $\mathrm{PMDB}$, reuniões secretas, apoio firme com votos à reeleição, caracterizadas como manobras fisiológicas. O presidente, por sua vez, nessa tajetória, mancha sua imagem ao lançar-se na busca de mais um mandato e, para minimizar os danos, deveria declarar-se fora da disputa, não usufruindo do privilégio da emenda.

\section{Discussão}

Nos editoriais de OESP examinados, a reelegibilidade representa a vontade da maioria da população, enquanto o presidente atual é o único político que reúne qualidades necessárias para conduzir o país. O plebiscito é um procedimento dispensável e até mesmo nocivo, porque tomaria tempo demais, devendo ser evitado. $\mathrm{O}$ eventual desgaste do presidente deve ser debitado aos parlamentares, especialmento os do PMDB, partido movido a interesses pessoais, que procura tirar partido de sua posição no Congresso. $\mathrm{O}$ desgaste do presidente parece uma consequência perversa da necessidade de intervir no processo.

Os editoriais não discutem a legitimidade ou validade da reelegibilidade, apenas tratam dela no momento político, em face do governo atual, ou seja, a justificativa alegada para sua adoção é pessoal e conjuntural. Nesse sentido, o jornal não poupa elogios a FHC e à sua "obra realizada", embutindo uma chantagem com os eleitores: "se não for Fernando Henrique, então, quem?” Essa formulação 
lembra o que Perelman chama de argumento do desperdício ("depois do que conseguimos, não podemos correr o risco de pôr tudo a perder").

Os editoriais de OESP têm uma plataforma imediata e tangível: a popularidade, o prestígio intelectual de FHC, cujo governo é apresentado como honesto, competente e, sobretudo, responsável pela estabilidade monetária. Por isso, acenam com um próximo mandato de inequívocas realizações, por meio da continuidade administrativa. Os pontos positivos da administração FHC são ressaltados de maneira a arredar seus possíveis aspectos controvertidos e problemáticos. Assim, nem sequer há necessidade de defendê-lo destes últimos. Trata-se de uma administração singular, realizada por um homem culto e competente. Lamenta-se, tão somente, a lentidão do processo de votação da emenda, que acaba por paralisar o governo, bem como as concessões e barganhas que foram exigidas do Executivo. Em ambos os casos, o governo é retratado como vítima desse processo, que na verdade se origina da determinação do Planalto em aprovar a emenda.

Em todos os casos, o pensamento é ad hoc, justificado em última análise pelo protagonista do espetáculo, Fernando Henrique Cardoso, e suas qualidades pessoais. Uma súbita insegurança, um sentimento angustiante de orfandade perpassam a pergunta implícita sobre o futuro sem ele. O clima redentorista instala-se explicitamente no texto, de modo que até mesmo mudar a Constituição em benefício imediato do atual titular da Presidência aparece como alternativa legítima, porque responde a todas as dúvidas, oferecendo uma unanimidade tranquilizadora.

$\mathrm{Na}$ verdade, parece relativamente simples defender a continuidade de um governo representado como sendo competente, projetando hipoteticamente essa situação para futuros cenários. Um fim tão almejado, como o bem-estar da sociedade, legitima os meios a serem empregados, enquanto as questões de princípios escorregam facilmente para um plano secundário. Ao mesmo tempo, a ideia do oportunismo de legislar em causa própria esmaece, mesmo porque não haveria sentido em propor a emenda para um futuro governo, 
uma vez que a motivação vem justamente do entusiasmo com o governo FHC e seu favoritismo nas pesquisas.

A FSP, embora apóie a reeleição, não se estende em argumentos a seu favor, nem nos elogios a FHC, insistindo, antes, na importância do plebiscito, como forma de não só de permitir a participação da sociedade, como de livrar o presidente das pressões dos parlamentares, com seus interesses mesquinhos. Defende que presidente não deve se afastar do cargo para concorrer a um novo mandato, para não neutralizar os supostos efeitos benéficos da continuidade do governo. A não-aprovação da emenda teria sido nociva às reformas, mas o processo de votação preteriu questões mais importantes, que não receberam atenção devida e, com isso, o país viveu uma estagnação durante o período de discussão. Na FSP, portanto, há um equilíbrio entre o que seria uma aceitação da reelegibilidade e uma crítica formal aos procedimentos adotados, fazendo recair a responsabilidade pelas barganhas exclusivamente no parlamento, em interesses menores de integrantes do Legislativo, o que parece corresponder a uma visão tradicional da imprensa sobre os poderes. Enquanto isso, o Executivo foi representado como refém inocente das pressões, em especial das do PMDB.

Os poucos artigos de colaboradores favoráveis à aprovação da emenda foram publicados unicamente na FSP. Os defensores da emenda da reeleição são políticos, intelectuais ou tecnocratas vinculados à coalisão governista, argumentando com base na ideia de que um governo bom e honrado merece concorrer a um novo mandato, o que significaria para o eleitor ter o direito de escolha ampliado. $\mathrm{Na}$ verdade, essa forma aparentemente impessoal de colocar as ideias oculta a verdadeira motivação da iniciativa: o favoritismo de FHC obtido com o sucesso da estabilização monetária. Adota-se, portanto, uma linha de argumentação que finge ignorar a natureza casuística da emenda, invocando a exiguidade dos quatro anos para um bom governo, deixando implícito, no entanto, que o país precisa de FHC, cumprindo, pois, dar-lhe a possibilidade de recondução.

Políticos de partidos que apoiam FHC, aliados e editorialistas dos jornais analisados partiram, geralmente, de uma aceitação declarada 
ou tácita do absoluto sucesso do governo, desenvolvendo, a partir daí, uma argumentação pragmática, que propugna adotar agora a reeleição. Isso significa, em outras palavras, que as instituições - leiase a Constituição - devem curvar-se ante as supostas qualidades e vontades do governante do momento.

Alguns autores nem sequer argumentaram sobre a validade ou oportunidade da reeleição, defendendo diretamente a necessidade de decidir rapidamente sobre ela ou mesmo sobre a inconveniência da desincompatibilização do governante, que acabaria tirando o efeito benéfico da continuidade governamental.

Prevalece, no entanto, o número de manifestações de colaboradores contrários à reeleição, que buscaram desqualificar o processo, representando-o como um casuísmo, legislação em causa própria, interesse pessoal de FHC, manipulação eleitoral, manobra continuísta, uma forma de beneficiar os candidatos oficiais, pretexto para deixar de lado as reformas, "óleo de cobra", criação de normas incompatíveis com a democracia, origem de cobranças futuras, de governos preocupados com a reeleição. Ou seja, aqui, também, nem sempre os argumentos foram doutrinários, fixando-se mais no interesse pessoal de Fernando Henrique, no continuísmo, sem desenvolver análises em profundidade sobre o papel da reelegibilidade no processo político brasileiro. Parte dos artigos dedicou-se também a lamentar os aspectos antiéticos da forma como se deram a tramitação, as barganhas e, por fim, o custo para a sociedade brasileira da concentração das atenções num único tema, durante tanto tempo.

As críticas à emenda vieram de extremos do campo político, distribuindo-se por autores muito diversos, de modo que acabou havendo uma dispersão da argumentação, ora para a ironia, ora para aspectos formais, ora para aspectos políticos, enquanto a defesa da emenda adotou uma argumentação unificada, com base na apresentação dos aspectos tidos como positivos do governo atual e, portanto, dos efeitos benéficos de um novo mandato de FHC, tanto quanto dos demais bons governantes. A heterogeneidade das posições parece ter acabado por promover uma dispersão das representações, que, em vez de fortalecer a crítica, parece diluí-la. No que diz respeito aos 
articulistas de esquerda, não transcenderam o episódio analisado, buscando estabelecer relações mais compreensivas entre o esforço da reeleição e a estratégia conservadora global dos grupos no poder, hipótese deste capítulo, limitando-se a críticas aos interesses imediatos e atitudes pessoais do presidente, ao governo, aos parlamentares, à política econômica etc.

Em suma: por um lado, os dois mais importantes jornais de São Paulo foram unânimes em apoiar a emenda e seu beneficiário, em especial OESP, que adotou um tom bastante oficialista, enquanto a FSP manteve certo distanciamento, insistindo na tese do plebiscito. Por outro lado, houve poucos artigos favoráveis à reeleição e muitos contrários a ela, vindos, na maioria das vezes, do espectro de adversários políticos do presidente. Ora, como os jornais se apresentam como entidades neutras politicamente e defensoras do "bem comum", sua posição aparenta uma independência do jogo político, ao passo que as críticas representam sempre a voz dos prejudicados com a emenda, ou seja, vozes interessadas (para não dizer interesseiras). Por conseguinte, a emenda pode ter logrado uma espécie de aura de unanimidade, se se consideram as posições dos veículos analisados. Enquanto isso, as críticas que os jornais abrigaram, contrárias aos seus editoriais, ao estabelecerem alguma controvérsia, pareciam, afinal, apenas revelar o ambiente de grande liberdade democrática, no qual se dava a votação da emenda. Mas ninguém chegou a escrever sobre isso.

\section{Referências bibliográficas}

\section{I - Livros, artigos e teses}

AGUIAR, C. B. de. Imprensa e eleições 1989: razão e sedução na opinião das elites. São Paulo, 1993, 340p. Tese (Doutorado em Ciências da Comunicação) - Escola de Comunicações e Artes, Universidade de São Paulo.

LIMA, V. A. Os midia e o cenário de representação da política. Lua nova, São Paulo, n.38, p.239-71, 1996.

SOARES, Murilo Cesar. Percepções e critérios dos eleitores na campanha eleitoral de 1994. (Trabalho apresentado no GT de Comunicação e 
Política do IV Encontro da Associação Nacional de Pós-Graduação em Comunicação Social, Brasília, 1995). Unesp, 1995. 12p. (Mimeogr.). Os significados do voto. (Trabalho apresentado no GT de Comunicaçào e Política do V Encontro da Compós, São Paulo, maio de 1996) Unesp, 1995, 12 p.(Mimeogr.).

PERELMAN, C., OLBRECHTS-TYTECA, L. Tratado da argumentação.

São Paulo: Martins Fontes, 1996.

\section{II - Editoriais de jornais}

A AGONIA da reeleição. Folha de S. Paulo, 22-01-97, p.2.

A BATALHA de Brasília. Folha de S. Paulo, 29-01-97, p.2.

A OUSADIA DOS MEIOS. Folha de S. Paulo, 24-01-97, p.2.

AGORA, às reformas. O Estado de S. Paulo, 31-01-97, p.3.

A META da reeleição está mais próxima. O Estado de S. Paulo, 16-01-97, p.3.

AOVOTO, senhores. Folha de S. Paulo, 17-01-97, p.2.

APENAS uma etapa vencida. O Estado de S. Paulo, 30-01-97, p.3.

CONVIDADO de pedra. Folha de S. Paulo, 14-01-97, p.2.

CRITICAR e propor. Folha de S. Paulo, 13-01-97, p.2.

DEDICAÇÃO política. Folha de S. Paulo, 26-01-97.

DOIS, quatro ou seis. Folha de S. Paulo, 16-01-97, p.2.

FUMAÇA sem fogo na convenção do PMDB. O Estado de S. Paulo,14-01-97, p.3.

IMPREVISÍVEL política. Folha de S. Paulo, 02-02-97, p.2.

INVESTIGAR a fundo. Folha de S. Paulo, 25-01-97, p.2.

LEGISLATIVO subestimado. Folha de S. Paulo, 21-01-97, p.2.

MOROSIDADE parlamentar. Folha de S. Paulo, 03-02-97, p.2.

MUDANDO a fisionomia do país. O Estado de S. Paulo, 21-01-97, p.3.

NÃO se deve trocar "alguma coisa" por "nada". O Estado de S. Paulo, 23-01-97, p.3.

O QUE o Congresso tem a fazer. O Estado de S. Paulo, 17-01-97, p.3.

REAÇÃO na hora exata. O Estado de S. Paulo, 15-01-97, p.3.

SAIR para quê? Folha de S. Paulo, 31-01-97, p.2.

SEM euforia. Folha de S. Paulo, 30-01-97, p.2.

SOLUÇÃO para o impasse. Folha de S. Paulo, 28-01-97, p.2.

UMA questão de empenho. O Estado de S. Paulo, 02-02-97, p.3. 


\section{III - Artigos de colaboradores}

AFFONSO, A. Reeleição e plebiscito. Folha de S. Paulo, 22-01-97.

ÁLVARES, É. A recandidatura de FHC. Folha de S. Paulo, 27-01-97.

BICUDO, H. Reeleição, plebiscito e referendo. Folha de S. Paulo, 13-01-97.

CASTRO, P. R. de. FH tem sido prudente e desagradavelmente lento. $O$

Estado de S. Paulo, 26-01-97.

DELFIM NETO, A. A reeleição e o óleo de cobra. Folha de S. Paulo, 22-01-97.

DIRCEU, J. A responsabilidade histórica de FHC. Folha de S. Paulo, 29-01-97.

FERREIRA, C. E. M. Decisão já. Folha de S. Paulo, 21-07-97.

LIMA, E. U. Reeleição com plebiscito. Folha de S. Paulo, 27-01-97.

MONTORO, A. F. Reeleição e consulta nacional. Folha de S. Paulo, 15-01-97.

MOTA, L. de G. Reeleição e plebiscito. Folha de S. Paulo, 28-01-97.

MOURÃO, G. M. A ética e a reeleição. Folha de S. Paulo, 23-01-97.

PASSARINHO, J. O costume de mudar. O Estado de S. Paulo, 28-01-97.

REALE JÚNIOR, M. Reeleição no exercício do cargo. Folha de S. Paulo, 02-02-97.

REBELO, A. Candidato a caudilho. Folha de S. Paulo, 14-01-97.

REQUIÃO, R. Ai de ti, PMDB! Folha de S. Paulo, 16-01-97.

RESENDE, A. L. Riscos. Folha de S. Paulo, 21-01-97.

SADER, E. Pyongyang é aqui. Folha de S. Paulo, 17-01-97.

O avesso do avesso. Folha de S. Paulo, 02-02-97.

SARNEY, J. As orcas e a reeleição. Folha de S. Paulo, 10-01-97.

Da popularidade. Folha de S. Paulo, 17-01-97.

O povo ou a capoeira. Folha de S. Paulo, 24-01-97.

A ressaca da vitória. Folha de S. Paulo, 31-01-97.

SOUZA, H. de. Reeleição e os dinossauros. Folha de S. Paulo, 28-01-97.

TORQUATO, G. PMDB, entre a cruz e a espada. O Estado de S. Paulo, 27-01-97.

WEIS, L. O preço da consulta. O Estado de S. Paulo, 27-01-97. 


\section{9 \\ A CRISE POLÍTICA \\ NA ESFERA PÚBLICA MEDIATIZADA}

\section{Introdução}

O mês de junho de 2005 foi marcado denúncias de corrupção envolvendo figuras do governo brasileiro, a direção do Partido dos Trabalhadores e parlamentares de outros partidos, dando origem a uma grave crise política. O processo foi desencadeado por uma revelação divulgada no próprio âmbito mediático e que alcançou enorme repercussão pela imprensa e pela televisão. Este capítulo toma a crise e sua divulgação como um aspecto da esfera pública mediática, na qual transcorre o drama político. Wolton (1995) defende que a esfera pública contemporânea é instaurada pela comunicação mediática, a qual também constitui uma condição estrutural do funcionamento da democracia, que pressupõe um espaço para o debate dos grandes problemas do momento.

\section{Os meios e a crise}

No início de toda a série de acontecimentos do dominó político brasileiro de 2005 está uma reportagem da revista Veja, revelando o caso de um funcionário dos Correios, filmado ao receber uma quantia 
em dinheiro, que citava o deputado federal Roberto Jefferson, presidente do PTB, como responsável pelo controle de um esquema de corrupção. Na sequência, a gravação do episódio foi mostrada em reportagem do Jornal nacional, de outros telejornais e apareceu em matérias de praticamente todos os jornais brasileiros.

Pressionado pelo envolvimento de seu nome, o deputado Jefferson solicitou entrevista ao jornal Folha de S. Paulo, na qual declarou que dirigentes do PT realizavam uma distribuição mensal de somas em dinheiro para deputados do PP e do PL, partidos da chamada "base aliada" do governo, indicando como responsável pelo esquema o ministro-chefe da Casa Civil. O teor da entrevista novamente foi difundido pelo noticiário dos telejornais, inclusive o $J N$, o que significa amplificar de cerca de centenas de milhares de leitores da Folha para várias dezenas de milhões de telespectadores brasileiros. Em reação à denúncia de Jefferson, a Câmara dos Deputados instalou uma comissão de ética para julgar o deputado por quebra do decoro parlamentar. Na comissão, Jefferson, em depoimento, reafirmou a denúncia feita à Folha, acrescentou inúmeros pormenores da operação, indicando nomes, em uma fala de várias horas, transmitida ao vivo por alguns canais de televisão aberta e por assinatura. À noite, os telejornais tinham um tema amplificado, de conteúdo extremamente grave, dando envergadura inédita à crise política. $\mathrm{O}$ fato ganhara uma repercussão mediática enorme, tornando-se onipresente.

Como consequência desses acontecimentos, deu-se a instalação de uma Comissão Parlamentar de Inquérito (CPI) para investigar a fraude nos correios, origem de todo o processo. A CPI propiciou novo depoimento de Jefferson e, também, da ex-secretária do publicitário acusado de ser o operador financeiro do esquema de corrupção, a qual confirmaria as denúncias do deputado sobre distribuição de dinheiro a parlamentares. Posteriormente, outras CPIs foram instaladas: uma para investigar a distribuição de mesada aos deputados e outra sobre a questão dos jogos de bingo, envolvendo um ex-auxiliar do ministro-chefe da Casa Civil.

Com a avalanche de novos fatos, novos depoimentos, novas denúncias, novos indícios, apreensões pela Polícia Federal de dinheiro 
com ligação a políticos, a questão da corrupção tornou-se rapidamente o tema mais destacado e mais longo dos telejornais, dos jornais e das revistas semanais, figurando invariavelmente em manchetes bombásticas e capas dramáticas. Na TV, além dos noticiários, o tema tornou-se objeto de programas voltados às donas-de-casa, talk-shows, entrevistas e humorísticos, ganhando diversos horários do dia e da noite, impondo-se pela onipresença como item prioritário da agenda pública. O exame sistemático do noticiário desse período ainda precisa ser feito em pormenor, mas aqui queremos sugerir algumas reflexões preliminares.

A difusão sistemática dos acontecimentos para a sociedade colocou-os totalmente fora de controle do governo ou dos partidos, levando à imprevisibilidade sobre os seus rumos e consequências. Além disso, a divulgação de revelações de bastidores, comentários off the record de políticos e autoridades, conversações de grupos, reuniões envolvendo lideranças, opiniões etc, agregou novas informações, de modo que o assunto se manteve "no ar" - e por mais tempo - nos telejornais ou no espaço editorial dos meios impressos. As manchetes, closes de personalidades em lágrimas ou com expressão de aparente desespero, capas dramáticas das revistas semanais atuaram com expressividade, criando intensidade, teatralidade, tensão, capazes de manter o tema na agenda e de interpretar retoricamente o momento. No telejornalismo, a "escalada" de notícias (expressão usada para a sequência de abertura do telejornal em que os apresentadores anunciam as reportagens) criava um efeito de urgência para as novas revelações. Esses elementos expressivos - além da gravidade própria dos fatos-colaboraram para tematizar de forma intensa os episódios, conferindo-lhes a aparência de fatos incontornáveis, clamando por encaminhamentos ou soluções. O problema não se limitou, portanto, aos círculos palacianos ou ao âmbito do congresso, sendo, desde o início, uma questão pública a desenrolar-se no campo mediático. As instâncias formais de poder tornaram-se, em certos momentos, reféns dos meios, forçadas a agir ou a posicionar-se devido à divulgação dada aos fatos pelo noticiário e à sua repercussão em outros gêneros e formatos mediáticos. 
Não tardaram os anúncios de demissões, exonerações de diretores de estatais, pedidos de afastamento de diretores do PT, a retomada do projeto de reforma política (em especial, o capítulo do financiamento público das campanhas), a abertura de inquéritos policiais e uma minirreforma ministerial, com vistas a criar maior apoio político para o governo. São medidas que evidenciam a repercussão política e administrativa não apenas dos acontecimentos em si, mas de sua divulgação mediática, a qual pressionou de tal forma os responsáveis que tornou imperiosa, do ponto de vista político, a implementação de algumas mudanças.

A rápida passagem pelos acontecimentos mostra uma variedade de tipos de ações da mídia, algumas das quais elencamos abaixo:

- As denúncias. A revelação de ilegalidades envolvendo autoridades, documentadas por gravações, repercute no campo mediático e desencadeia processos de reação, forçando a tomada de medidas pelas autoridades responsáveis, no âmbito político, administrativo, jurídico e policial.

- Entrevistas. Da mesma forma que as denúncias, entrevistas concedidas a um meio de comunicação, em que os entrevistados trazem informações importantes e inéditas, têm efeitos em cadeia nos demais meios.

- Investigações. Conduzidas por iniciativa dos meios noticiosos, as reportagens investigativas podem apurar dados novos, cruzar documentos, localizar testemunhas, fazer ilações e inferências que resultam em novas interpretações. Nesse caso, a imprensa age como uma instância de poder paralela às instâncias legais, as quais eventualmente são forçadas a tomar atitudes a respeito das revelações obtidas. Frequentemente, as matérias podem se tornar parte do próprio processo político, passando a integrar os acontecimentos e precipitando seus desdobramentos.

- As transmissões ao vivo. Tipo de ação peculiar à radiodifusão, em especial à televisão, as transmissões de sessões de órgãos parlamentares incumbidas de ouvir testemunhas e acusados (Comissão de Ética da Câmara, as CPIs) suscitam nos espec- 
tadores a sensação de serem testemunhas e participantes dos acontecimentos, que são convertidos em tema obrigatório das conversas do cotidiano. As transmissões amplificam o significado do assunto na agenda pública, aumentando sua importância, além de transferirem aos mesmos a coloração emocional própria dos debates. Também é inevitável que os acontecimentos sejam convertidos em espetáculo teatral, com personagens, conflitos, drama etc. Atores com maior talento destacam-se pelo histrionismo; bons oradores, pela argumentação.

- Vazamentos. A divulgação de conversas e acordos de bastidores entre autoridades, políticos ou lideranças tem o dom de abortar acertos convenientes a alguns atores políticos, mas prejudiciais aos demais ou ao andamento das apurações.

- A interpretação. A avaliação política, moral ou econômica dos fatos, em editoriais, colunas, comentários ou matérias assinadas na imprensa contribui para a construção dos seus significados públicos, no contexto de uma disputa pelo sentido dos acontecimentos, na perspectiva de jornalistas, especialistas, intelectuais ou lideranças.

- A contextualização dos acontecimentos. As reportagens podem conter retrospectivas, historiar os fatos, compará-los com momentos semelhantes no passado ou em outras sociedades, dando-lhes uma dimensão relativa.

Esses gêneros e formatos jornalísticos mostram que, muito mais que meros canais de informações de outras arenas, os meios são protagonistas ativos da esfera pública contemporânea. Como ambiente e arena do debate público, legitimando vozes em diferentes posições sociais, os meios pressionam as instâncias do Estado obrigando-as a abandonarem as tendências corporativas e a se explicarem diretamente à opinião pública, coibindo acordos e acomodações em circuito fechado, bem como as saídas astuciosas, baseadas em tecnicalismos processuais.

Observa-se, por fim, que, na crise, o jornalismo alcança maior evidência do que na normalidade, devido ao aumento da imprevisi- 
bilidade dos acontecimentos, à situação de instabilidade das forças políticas, à percepção de mudança iminente, ao risco aumentado (por exemplo, na economia), à transição que se anuncia para uma nova ordem. É também saliente na crise o clima psicológico generalizado de decepção, o desejo de revanche contra maus políticos, a satisfação de ver delitos punidos. Por último, mas não menos importante, há o inevitável caráter de espetáculo, de teatro, do autêntico reality show proporcionado pelos interrogatórios, pelas discussões e depoimentos transmitidos diariamente ao vivo pelas CPIs. Essa abordagem espetacular está presente também na narrativa dos noticiários de TV, na reverberação das manchetes dos jornais e das capas chamativas das revistas semanais.

\section{Discussão}

Os meios de comunicação integram, ao lado do Estado e da opinião pública, o próprio campo da política contemporânea. Na crise, são os responsáveis pela divulgação dos desvios e pela manutenção em evidência dos seus desdobramentos, agendando-os de forma sistemática, a ponto de evidenciarem a necessidade de reafirmação das normas sociais e dos princípios republicanos. Esta ação pode aparecer sob a forma da simples convocação para depor, da publicidade dada aos depoimentos, ou por meio da punição efetiva dos responsáveis, com seu afastamento de funções públicas, exoneração, cassação de mandatos, perda de direitos políticos e de status social, condenação judicial.

Importante para esse resultado é a consonância geral do discurso a respeito da orientação delituosa dos fatos denunciados. Não há uma voz discordante em todo o espectro mediático de que desvios graves vinham acontecendo e que não devem ser exclusividade do PT ou dos partidos da "base aliada", mas algo que impregna a política brasileira. Também é uma reclamação geral - na imprensa e fora dela - que é preciso averiguar, punir e, sobretudo, sanear a política e a administração pública brasileira. Essa unanimidade é legitimada 
pelo fato de que a corrupção é um tipo de uma privatização da coisa pública, que não beneficia senão os próprios praticantes. No campo empresarial, a corrupção foi apontada em diversos momentos como sendo uma forma de concorrência desleal. Para todos os demais cidadãos - pobres ou ricos - a corrupção significa em todo o mundo menos recursos públicos para investimentos, obras, projetos sociais, financiamentos que possam promover o bem comum, o interesse público, o desenvolvimento econômico e social.

Dessa percepção do caráter injusto e antissocial da corrupção provavelmente advém o ímpeto com que a imprensa se dedicou à ampla cobertura dos fatos e mesmo a sua convergência valorativa a respeito deles. $\mathrm{O}$ fato de os meios constituírem um amplo setor da iniciativa privada, portanto, destacado de uma subordinação imediata do Estado, confere a eles uma relativa liberdade de atuação. Além disso, é exatamente esse tipo de independência que os leitores esperam da imprensa em geral e, em particular, dos jornalistas como profissionais. Dessa maneira, da situação peculiar da imprensa - uma quase instituição pública não-estatal - advém o seu papel nesse processo. Adicione-se que essa quase instituição não é centralizada, mas plural, ligada a grupos distintos, o que permite a ação de pesos e contrapesos, controlando excessos possíveis de um ou outro veículo.

Apesar de que não se trata de uma imprensa com perspectiva popular (uma vez que é propriedade de grupos econômicos privados), ela pode defender alguns valores que interessam à maioria da sociedade, independentemente das classes sociais, como a lisura na administração pública. No entanto, não é frequente no jornalismo alcançar esse denominador comum com o conjunto da sociedade. Há temas com implicações imediatas para as maiorias, como educação, emprego, saúde, habitação, sobre quais a cobertura da imprensa é bastante parcimoniosa e muitas situações injustas e desumanas, de caráter crônico, não suscitam clamor mediático equivalente ao dos casos de corrupção ou desonestidade administrativa. Essa situação é indicativa de um viés na esfera pública mediática, cujas peculiaridades ainda é preciso analisar. 


\section{Referências bibliográficas}

GOMES, W. da S. Esfera pública, política e media. Trabalho apresentado no GT de Comunicação e Política da COMPÓS. São Leopoldo: Unisinos, 1997.

Sobre a transformação da política na era da comunicação de massa. Trabalho apresentado no GT de Comunicação e Política da COMPÓS. São Bernardo do Campo: Umesp, 2004.

Duas premissas para a compreensão da política-espetáculo. Revista de comunicação e linguagens. Comunicação e Política. Lisboa: Edições Cosmos, 21-22, 1995. 434p. Edição especial. p.299-317.

Esfera Pública e Media - II. Trabalho apresentado no GT de Comunicação e Política da COMPÓS. São Paulo: PUC,1998.

HABERMAS, J. Mudança estrutural da esfera pública. Rio de Janeiro: Tempo Brasileiro, 1984.

MESQUITA, M. Tendências da comunicação política. Revista de comunicação e linguagens. Comunicação e Política. Lisboa: Edições Cosmos, 21-22, 1995. 434p. Edição especial. p.383-402.

WOLTON, D. As contradições do espaço público mediatizado. Revista de comunicação e linguagens. Comunicação e Política. Lisboa: Cosmos, 21-22, 1995. 434p. Edição especial. p.167-88. 


\section{0 \\ LEGITIMIDADE E LEGALIDADE NOS ENQUADRAMENTOS JORNALÍSTICOS DA CAMPANHA PRESIDENCIAL DE 2006}

\section{Introdução}

Procuramos neste capítulo perspectivar as contribuições teóricas à democracia segundo dois princípios: o da legitimidade do poder, que compõe a questão democrática em seu sentido mais profundo de validade, e o da legalidade, implicando o respeito à linha de Direito, os critérios republicanos de submissão do poder à lei.

\section{A legitimidade}

A legitimidade foi um tema estudado originalmente por Max Weber, que a considerava uma forma de dominação política racional, diferenciando-se de outras formas como a tradicional e a carismática. No entanto, a discussão desenvolvida pelo sociólogo sob a denominação de legitimidade volta-se, na verdade, para questões declaradas por ele próprio como referentes à dominação legal, ou seja, de legalidade, denominação pela qual serão referidas em nosso texto. Empregamos o termo legitimidade para indicar questões de representatividade, mérito e identificação, as quais só ganharam sentido pleno e força no contexto de democracias de massa, ao longo do século 
XX. A legitimidade do governo é o problema básico da democracia e refere-se à aceitação popular do poder, entendendo que a democracia deve expressar a vontade da sociedade e corresponder a ela.

Para situar com nitidez esse princípio, é interessante opor tirania e democracia como polos antitéticos ideais, contendo entre eles um continuum de pontos intermediários, nos quais se podem situar as diversas formas de concretização democráticas históricas. No despotismo, a aquisição do poder, historicamente, envolve métodos não prescritos, maliciosos, clandestinos ou excludentes de outros postulantes ou se dá pela força pura e simples (manu militari). O método é instituído unilateralmente e monopolizado por um grupo, sendo, por conseguinte, socialmente particularizante, arrebatado por uma classe, um grupo ou partido.

Em contraste, na democracia, em tese, o acesso ao poder deve darse por meios competitivos universais, como por eleição ou por mérito (caso dos concursos para cargos públicos, por exemplo). Apenas para cargos e funções de confiança, adota-se um meio discricionário, no caso da indicação, quando o detentor do poder pelas urnas faz uso de sua investidura para selecionar colaboradores, como ministros e secretários. A indicação, portanto, deve ser usada limitadamente, uma vez que é um procedimento não democrático em si mesmo e cuja legitimidade advém de um mandato popular. A legitimidade está assentada na crença na soberania popular, segundo a qual o poder supremo está nas mãos do povo, o que revela certo ceticismo com relação aos políticos, por mais iluminados estadistas que sejam. Assim, eleições frequentes são necessárias para manter os políticos em xeque, como forma de evitar a corrupção de suas funções (Birch, 1993).

Para Sartori (1994), nas eleições estamos diante do "povo governante". Os votos expressam a experiência pré-eleitoral, de modo que as eleições promovem um governo baseado na opinião. Eleições sem opinião livre não têm qualquer conteúdo democrático, argumenta o autor, destacando que, nas democracias de hoje, os meios de massa desempenham um papel amplo e central na formação da opinião pública.

A democracia, sendo uma forma competitiva de obtenção do poder, é a expressão simbólica e civilizada do conflito social, mediante os 
partidos, o discurso, os debates, as campanhas. O governo democrático é uma arena para o confronto entre grupos organizados, que expressam interesses opostos e garantem a realização de compromissos que levem em conta esses interesses. O pluralismo radical considera que o conflito, em vez de ser um problema para a democracia, é uma de suas virtudes (Cunningham, 2001). Para os autores dessa corrente, não apenas o conflito é inevitável na vida social e política, como o seu reconhecimento e institucionalização pela cultura e instituições democráticas é uma defesa contra a autocracia. Ora, o conflito tem sua primeira manifestação na competição eleitoral, quando grupos adversários se opõem, mas o antagonismo atravessa os mandatos, com a disputa entre partidos situacionistas e opositores.

$\mathrm{O}$ conflito também remete à legitimidade, na medida em que implica o reconhecimento recíproco das posições de situação e de oposição e da existência do mérito do vencedor. Ribeiro (2002) considera que a democracia é um meio de resolver conflitos, porque aceita a divergência, renunciando à unanimidade. Os procedimentos democráticos significam que somos incapazes de definir racionalmente a melhor alternativa, numa disputa entre posições antagônicas sobre assuntos controvertidos de natureza política e social, sendo preferível resolvê-los pela discussão e pelo sufrágio. Resolver os conflitos por meio do voto torna a aceitação dos derrotados mais fácil do que usando outros procedimentos, sendo possível, por isso, produzir relações sociais melhores, mais pacíficas e maior cooperação. O caso da Índia a esse respeito é paradigmático: justamente a diversidade religiosa, étnica e linguística impulsiona a sociedade indiana para sua adesão à democracia (Dahl, 2001).

Autoridades precisam ter, também, representatividade política. Para isso, os postulantes devem ser defensores dos interesses e demandas das classes que representam. Na tirania, o poder concentra-se nas mãos do déspota, de um círculo próximo a ele ou, no máximo, do partido, do qual procedem as decisões. Nesse núcleo originam-se unilateralmente as determinações, as quais não admitem discussão ou recurso de outras instâncias. O núcleo do poder age como um buraco negro cósmico, a absorver todo o poder para seu interior, deformando completamente as noções de justiça, humanidade, equilíbrio e, por 
fim, de racionalidade. Em contraste, no governo democrático, o exercício do poder deve expressar a realização dos compromissos dos grupos eleitos com seu eleitorado, negociando pontos, de modo a fazer leis e implementar programas de ação consensuais. Assim, em última análise, o poder deverá ser exercido em consonância com a maioria, que sufragou um programa de governo, mas levando em conta outras vozes.

\section{A legalidade}

Enquanto a aquisição do poder pelo voto confere legitimidade social ao poder democrático, por meio da representatividade, o princípio da legalidade significa a linha de Direito e advém do controle do poder das autoridades pelas normas jurídicas. A legalidade expressa o princípio republicano do respeito à lei, ao bem comum, ao patrimônio, revelando o cuidado com a coisa pública, acima dos interesses e das reivindicações particulares de facções, categorias ou classes (Baker, 2001). O poder do déspota não é controlado por nenhuma instância ou pessoa. Suspendem-se as leis, os tribunais são encenações; os parlamentos são homologadores da vontade do ditador; a imprensa é censurada; as reuniões públicas são proibidas; os partidos de oposição são extintos; a educação política e social resume-se às cartilhas ortodoxas; as liberdades públicas desaparecem e a sociedade civil é absorvida pelas instâncias estatais. É o domínio da propaganda, da doutrinação sistemática e do controle da opinião pública. Na democracia, o exercício do poder dá-se com estrita observância às leis, sendo distribuído entre os poderes Executivo, Legislativo e Judiciário. O governo saído do sufrágio precisa compor uma equipe, delegando poderes, eventualmente, formando coalizões e distribuindo parcelas do poder entre partidos.

Na democracia, legitimidade e legalidade devem caminhar juntas, pois, modernamente, governo democrático significa necessariamente a vigência de princípios republicanos (ainda quando se trata de monarquias). O controle implica a vigilância (fiscalização), a delimitação do poder e das competências (pela lei) e a responsabilização (legal) dos detentores do poder. 
Bobbio (2000) resume a democracia ao "governo das leis", o conjunto de regras que estabelecem quem está autorizado a tomar as decisões coletivas e com quais procedimentos, sendo fundamental a regra da maioria. Ela se baseia nos direitos de liberdade de opinião e expressão, de reunião, de associação, que formaram a base do Estado liberal, pressuposto histórico e jurídico do Estado democrático e sobre o qual se constitui o Estado de Direito. Ribeiro (2002), na mesma linha, diz que o caráter democrático da política moderna é dado pelos direitos, que exprimem a pressão popular sobre o poder.

Por isso, o governo democrático possui instâncias que podem responsabilizar o governo ou titulares do poder político por desvios. O governo deve responder por seus atos a instâncias judiciais institucionalizadas e independentes. Assim, no próprio aparelho do Estado encontram-se os representantes dos partidos de oposição, os conselhos de ética, as comissões parlamentares de inquérito, o Ministério Público, a Defensoria Pública, o Judiciário, a Polícia Federal, os Tribunais de Contas, as corregedorias. As instâncias de responsabilização fiscalizam possíveis desvios com relação às leis ou à legalidade do governo, sobre assuntos como a corrupção, o abuso do poder, a usurpação, o uso da máquina a favor dos candidatos da situação. Se a legitimidade se refere às questões propriamente políticas, a legalidade diz respeito às questões do controle legal do poder.

A vigilância do poder, no entanto, é tarefa disseminada socialmente, tendo elementos que ultrapassam o aparelho do Estado, espraiando-se pela sociedade civil. Fora do Estado estão as associações, entidades de direitos civis, ordens profissionais, sindicatos, movimentos sociais, constituindo a opinião pública ou, numa forma mais orgânica, o que Habermas denominou esfera pública, de que faz parte a chamada esfera pública mediática, representada pela imprensa, redes de televisão e rádios, que podem funcionar como fóruns para a discussão dos problemas políticos e crítica da condução geral do governo. As instâncias de controle fora do governo podem atuar politicamente, cobrando compromissos, questionando a legalidade das ações, reivindicando priorização de certos pontos, apoiando políticas, denunciando os desvios etc. 
Resumindo, a Democracia, na sua concepção em termos normativos ideais, implica pelos princípios de legalidade:

- que a aquisição do poder se dê por meios universalmente distribuídos, respeitando, em primeiro lugar, a delegação originária do poder pela cidadania;

- que o poder seja distribuído em instâncias independentes;

- que o governo seja temporário, conduzido com respeito às leis, e em que haja controle e fiscalização efetiva dos órgãos, pessoas e agências do poder por instâncias públicas e pela sociedade civil, havendo a possibilidade efetiva de aplicação de sanções legais aos governantes.

\section{Enquadramentos}

A controvérsia central da campanha presidencial de 2006, no âmbito mediático, pode ser examinada pelo prisma da tensão entre as reivindicações de legalidade e legitimidade, que atuaram como enquadramentos antagônicos, definidores do significado do voto. Assim, neste capítulo, pretendemos verificar como os princípios democráticos de legitimidade e de legalidade, coincidentemente ou não, constituíram importantes enquadramentos noticiosos para as reportagens sobre a campanha eleitoral.

Segundo Entman, enquadramentos constituem propriedades específicas da narrativa noticiosa que encorajam percepções e pensamentos sobre eventos e compreensões particulares sobre eles. Os enquadramentos de notícias podem ser constituídos por palavras, metáforas, expressões, ironias, imagens visuais, insinuações e sugestões da narrativa noticiosa. São dois os fatores essenciais do enquadramento: seleção e saliência: "Enquadrar é selecionar alguns aspectos de uma realidade percebida e torná-los mais salientes num texto comunicativo, de modo a promover uma definição de problema particular, uma interpretação causal, avaliação moral e ou recomendação de tratamento" (Entman, 1993). 
A clivagem mediática em duas perspectivas foi muito evidente nas campanhas eleitorais e entre as revistas e nos chamados blogs políticos: uns enquadrando a candidatura de Lula a partir de sua representatividade, outros questionando o candidato com base em questões "éticas", embora, a rigor, fossem mais propriamente questões legais, haja vista que migraram para o terreno dos inquéritos policiais e processos judiciais. ${ }^{1}$

Uma forma assumida pelo enquadramento de legitimidade foram referências seja à vantagem de Lula em termos de intenções de voto, verificadas nas pesquisas eleitorais (indicativas do apoio popular), seja às políticas sociais do governo, implementadas durante o primeiro mandato, as quais se disseminaram entre as camadas de menor renda, alcançando agregados extensos.

Por sua vez, as referências às denúncias de problemas "éticos" do governo e da campanha do PT, como dissemos, participaram da constituição do enquadramento da legalidade. Além das questões surgidas no ano de 2005, como o chamado "mensalão", destacou-se, durante a própria campanha, a prisão pela Polícia Federal de integrantes da campanha do candidato do PT ao governo do estado de São Paulo, envolvidos na tentativa de comprar uma documentação contra o adversário, candidato do PSDB, favorito nas pesquisas, sobre sua alegada participação em esquemas de corrupção, no tempo em que fora ministro da Saúde do governo anterior.

O tema da legalidade foi o enquadramento dominante das reportagens da revista Veja, com diversas denúncias de corrupção contra integrantes do governo e do PT, as quais constituíam também o principal argumento da campanha do adversário de Lula, Geraldo Alkmin. Enquanto isso, o apelo à legitimidade esteve na base da campanha pela reeleição de Lula, aparecendo, também, nos enquadramentos das matérias das revistas Carta capital e Isto é, que desta-

1 A preferência pela menção à ética talvez se deva ao fato de que, no Brasil, o epíteto "legalista" é considerado "direitista", embora poucos se lembrem, por exemplo, que a campanha pela posse do vice-presidente João Goulart, em 1961, contra a qual se insurgiam os setores golpistas, tenha se baseado exatamente no princípio da legalidade, violado, afinal, em 1964. 
caram a representatividade popular do governo e do candidato, formando um enquadramento mais complexo, cheio de deslizamentos semânticos, culturais e de valores políticos implícitos (como avanço versus retrocesso político). Essas publicações também invertiam as acusações no chamado "caso do dossiê", denunciando implicações do Ministério da Saúde, durante Governo Fernando Henrique Cardoso, na operação de compra de ambulâncias superfaturadas.

Uma análise das expressões das matérias políticas de edições da revista Carta capital, de 27 de setembro e de 11 de outubro, mostra como a publicação enquadrou a personagem do presidente por meio de expressões ligadas ao tema da legitimidade, ${ }^{2}$ seja salientando sua vantagem nas pesquisas, que denotam apoio popular, sejam os sucessos de sua política econômica e social. Enquanto isso, os enquadramentos das duas edições de Veja baseavam-se em questionamentos da legalidade da candidatura Lula, em razão de denúncias referentes ao mensalão, ao caso do dossiê, entre outras, Nas duas edições, Veja empregou duas expressões relativas à legitimidade da campanha de Lula e 12 expressões críticas da sua legalidade, enquanto Carta capital utilizou, respectivamente, 11 e oito expressões. Alguns exemplos dessas ocorrências podem ser vistos nos quadros 1 e 2 .

Quadro 1: Expressões de Carta capital referentes a Lula, no enquadramento de legitimidade

Carta capital, 27 de agosto: Sólida estabilidade na candidatura Lula; no Nordeste, Lula massacra seu adversário; há uma aprovação maciça do governo entre os brasileiros que ganham até um salário mínimo; favoritismo de Lula; Lula está melhor hoje do que, por exemplo, Fernando Henrique Cardoso em meados de 1998; Lula está sendo votado apesar do 'mensalão' e não porque o 'mensalão' é irrelevante para seus eleitores; o programa (Bolsa Família) é a promessa cumprida, o compromisso básico que Lula honrou.

Carta capital 11 de outubro: $\mathrm{O}$ kart de Lula acelerou mais rápido que o de Alckmin; Lula ainda é o favorito; crescente e consistente votação do presidente ao longo dos anos; as primeiras sondagens de opinião [...] sorriam de novo para Lula.

2 Os quadros 1 e 2 estão baseados no trabalho acadêmico de estudantes de Sociologia da Comunicação Higueras, C. E. D., Alvarez, F. L. e Mendes, M. P. V. R., realizado em 2006. 
Quadro 2: Expressões utilizadas por Veja para referir-se a Lula, no enquadramento de legalidade.

Veja, 27 de setembro: complacente; patrono da desastrada compra com dinheiro sujo do falso dossiê; é altamente provável que Lula soubesse que, no seu comitê reeleitoral, havia um bunker clandestino; nunca um presidente se cercou de tanta gente suspeita; tudo indica que, com a eleição de Lula, o aparelho estatal foi tomado de assalto por seus asseclas cevados no banditismo partidário-sindical; métodos criminosos.

Veja, 11 de outubro: não-republicano; arrogância; fugir do debate.

O Partido dos Trabalhadores também recebeu de Veja um enquadramento pelo prisma da legalidade, no mesmo período, expresso em escolhas textuais como exemplificadas no quadro 3:

Quadro 3: Expressões referentes ao PT, no enquadramento da legalidade, em Veja.

O PT e Lula já tinham levado a proporções épicas a corrupção governamental; onda anti-PT gerada pelo episódio; a turma petista armou a bandalheira da compra com dinheiro sujo do falso dossiê contra tucanos; a militância sentiu o golpe do dossiê e ficou envergonhada com a dinheirama de reais e dólares e não achou argumentos para explicar o ocorrido; sucessão de escândalos que o PT vem financiando; o PT, mesmo depois de um escândalo atrás do outro, surpreendeu nas urnas; sucessivos escândalos; com seus métodos criminosos, o PT lançou o país em uma grave crise política; rica trajetória de delinquências; notória ausência de ética e moral da esquerda; impressionante multiplicidade de ações irregulares patrocinadas pelo governo e seu partido; dinheiros clandestinos que circulam nos desvãos do PT; caixa dois do PT; submundo petista; guerra eleitoral suja do PT; circunscrever a sujeira ao âmbito paulista do Partido dos Trabalhadores; esgoto sindical do Partido dos Trabalhadores; há fortes indícios de que ao menos parte dos dólares encontrados com os petistas entrou de maneira ilegal; dinheirama do PT; dólares petistas que comprariam serviços dos Vedoin.

Comparando os enquadramentos das revistas Veja e Isto é do período de 29 de outubro a 15 de novembro, ${ }^{3}$ percebe-se que Veja fez 86 referências aos escândalos, empregando expressões como crime eleitoral, abuso de poder, origem ilícita (do dinheiro), abuso, dinheiro petista, dutos de esgoto. Por sua vez, Isto é se referiu aos escândalos

3 Dados produzidos pelos estudantes de Sociologia da Comunicação Alcantarilla, I. P., Enrico, L. e Mota, R., em trabalho acadêmico de 2006. 
apenas 21 vezes, com expressões menos contundentes como acusações, sucessão de escândalos, juntar os cacos, crise, desmandos éticos.

Divergência muito mais nítida pode ser observada também entre os blogs jornalísticos. Por exemplo, o Blog do Noblat, ligado ao jornal O Estado de S. Paulo, focaliza exclusivamente os problemas do governo e do PT, que são ironizados em dezenas de comentários dos leitores. Já os blogs Conversa afiada, do jonalista Paulo Henrique Amorin, e Carta maior destacam unicamente as realizações econômicas e o significado político de um governo eleito de base popular, defendem-no dos seus críticos, o primeiro adotando o tom de sarcasmo contra integrantes da situação, o segundo usando um tom mais combativo.

É importante frisar que há suspeitas e denúncias de corrupção também contra candidatos do PSDB, principal partido da oposição ao PT, referentes aos governos anteriores daquele partido, mas o foco principal das reportagens da grande imprensa recaiu nas denúncias contra o governo e o PT. Provavelmente por essa circunstância, divulgou-se uma queixa dos situacionistas de que a imprensa estaria contra a candidatura do PT, sendo que a cobertura jornalística das denúncias motivou reclamações do próprio presidente interino do partido, em entrevista à Folha de S. Paulo, logo após a vitória de Lula.

Assim, num contexto de grande polarização, esses meios de comunicação, frequentemente, optaram por assumir posições, mediante enquadramentos noticiosos. Não pareceu, na verificação realizada, tratar-se de enquadramentos eventuais, mas da expressão de um engajamento deliberado e ativo em um dos princípios (legitimidade/legalidade), que resultam em casos observáveis de atenuação das acusações ou da sua amplificação, conforme o posicionamento do veículo.

Essa partidarização tácita dos meios, aparentemente, relaciona-os a grupos interessados em ter voz na política ou os revela, eles próprios, como vozes interessadas, fazendo do jornalismo uma forma de propaganda invisível. A conduta de revistas e dos blogs em 2006 pode ser relacionada à crise financeira vivida pelos meios de comunicação no Brasil, que os aproximaria de grupos econômicos ou 
políticos. Essa circunstância pode ter contribuído para retirar uma maior complexidade dos enquadramentos das matérias jornalísticas, estreitando o limiar das apurações, levando a narrativas limitadas, que apresentam assuntos controvertidos como se fossem consensuais.

\section{Os enquadramentos e a reeleição}

Estudos controlados de recepção têm relacionado os enquadramentos noticiosos às percepções da audiência sobre os assuntos reportados, demonstrando que eles podem ter consequências sobre a forma como as audiências percebem e compreendem um assunto ou evento, podendo até mesmo alterar suas opiniões (Shen \& Edwards, 2005; Rhee, 1997). Os resultados têm sido estudados sob a denominação de "efeitos de enquadramento", que ocorreriam porque as pessoas têm a tendência para empregar "atalhos cognitivos" ou heurísticos para processar a informação, baseando-se nas informações disponíveis para fazerem seus julgamentos. Assim, se os meios noticiosos enfatizam determinada informação sobre um assunto, ela se torna acessível à audiência e pode afetar opiniões e atitudes.

No entanto, o enquadramento de legalidade, caracterizado pelas denúncias, apesar de muito difundido, em razão dos escândalos, não enfraqueceu a força eleitoral do candidato à reeleição, que chegou a crescer, levando-o à esmagadora vitória no segundo turno. ${ }^{4} \mathrm{O}$ u seja, com base nos resultados eleitorais, parece consequente a hipótese de que o eleitorado tenha efetivamente atribuído importância menor para as questões republicanas ou de legalidade. A alegação de que a maioria dos eleitores não tem acesso a jornais e revistas, nos quais o enquadramento da legalidade apareceu em reportagens mais pormenorizadas, não se sustenta, uma vez que os telejornais também noticiaram amplamente as denúncias. Assim, os resultados eleitorais

4 A votação nos candidatos parlamentares envolvidos em escândalos, aparentemente, foi afetada pelas denúncias e pelo seu enquadramento noticioso, com a não-reeleição da maioria deles e o enfraquecimento eleitoral de outros. 
sugerem que o tema não teve muita importância na construção do significado do voto para os eleitores. Como manifestou o ministro Ciro Gomes, Lula não teria ganhado no primeiro turno devido à economia, e não devido à crise instaurada pelo dossiê, arrematando: "E o povo lá quer saber de dossiêe?" (Fernandes, 2006)

Para discutir o impacto da comunicação sobre o eleitor, é preciso tomar como ponto de partida que a reeleição é um processo muito favorável à legitimidade do presidente em exercício, pois o candidato situacionista desfruta de uma maior visibilidade e status mais alto, numa sociedade que valoriza muito o respeito à autoridade. Também é preciso ter em vista que o processo todo ocorreu num quadro político em que a maioria dos partidos teve envolvimento com alguma denúncia, o que, em princípio, tornava-os mais ou menos equivalentes em termos "éticos". No ambiente de denúncias cruzadas, acusações recíprocas e suspeitas permanentes em relação a autoridades, as referências legais ou "éticas" talvez tenham ficado difusas e a questão dos valores tenha se relativizado para os eleitores, envolvidos num clima de ceticismo.

A imagem de legitimidade da candidatura de Lula, além disso, pode ser relacionada a um conjunto de outros fatores específicos. $\mathrm{O}$ horário de propaganda eleitoral gratuita permitiu um contraponto com o noticiário, favorecendo a disseminação do enquadramento de legitimidade. Lula apresentou, durante a campanha pela televisão, uma grande quantidade de realizações administrativas e políticas sociais, de âmbito nacional. Sucessos econômicos do governo Lula foram um trunfo importante para sua campanha, especialmente a recuperação do nível de emprego, aumentos nas exportações, reduções na taxa de juros (embora ainda muito altas à época das eleições), estabilidade monetária, pagamento do empréstimo tomado ao FMI, realizações da Petrobrás e um crescimento econômico ligeiramente maior do que o do antecessor.

Outro ponto, destacado nas pesquisas qualitativas do PT, é que Lula aparecia na campanha como representante simbólico de uma maioria que "chegou lá". Lula exerce uma liderança popular, construída ao longo de duas décadas, em que participou de todas 
as campanhas diretas para presidente pós-redemocratização. A percepção de Lula como representante dos trabalhadores em geral, simbolizando as maiorias, conferiria a ele uma grande legitimidade política.

A estratégia de campanha negativa de Alkmin, cobrando diretamente a questão da legalidade, durante o primeiro debate, soou aos eleitores como ofensiva ao presidente, o candidato de origem $e$ de grande apoio popular, sendo atenuada nos demais debates. Pelo contrário, as acusações a Alkmin de privatista podem ter reforçado a legitimidade da candidatura de Lula, enquadrando-o como defensor das empresas públicas.

O resultado das eleições de 2006, aparentemente, relativiza a sempre mencionada força do poder mediático convencional no processo eleitoral: Lula teria vencido apesar da mídia, no âmbito de um cenário de representação da política desfavorável. Em face da ampla cobertura jornalística dos problemas envolvendo o governo, o resultado eleitoral parece sinalizar inicialmente que o "poder da mídia" convencional, no processo eleitoral, não deve ser considerado como um dado bruto, mas que precisa ser examinado em relação à conjuntura, especialmente àquela formada por meios alternativos, de natureza econômica e social.

A considerar o resultado das urnas, o eleitorado, confrontado entre o enquadramento de legalidade relembrado diariamente pelo conjunto dos meios de comunicação e o da legitimidade, representado pelos sucessos econômicos do governo, percebeu a implicação de seu destino pessoal e coletivo nas políticas públicas, especialmente nos programas sociais. Na verdade, programas sociais são capilarizados na sociedade, atuando como um meio de comunicação alternativo, interpelando individualmente cada eleitor diretamente beneficiado por eles ou integrante de uma categoria, agregado ou comunidade em que haja pessoas beneficiadas. Um fenômeno de capilarização, com resultantes eleitorais semelhantes, ocorreu durante a campanha presidencial de 1994, quando o lançamento do Plano Real transformou a nova moeda em um meio de comunicação que concretizava o significado dos seus benefícios econômicos para a população, resul- 
tando na eleição, no primeiro turno, de Fernando Henrique Cardoso, ministro da Fazenda à época da idealização do Plano.

O governo Lula confirmou sua legitimidade, obtida com uma vitória inequívoca nas urnas, mas ainda tem de enfrentar uma série de problemas legais, e a discussão política passa a envolver inquéritos e tribunais. Enquanto isso, a oposição, temerosa da pecha de golpismo e, sobretudo, preocupada com a implicação de seus integrantes nas denúncias de corrupção relativas aos governos anteriores, abranda suas críticas após a derrota, à medida que Lula se fortalece com uma ampla coalizão partidária. Nesse contexto, a legitimidade adquire mais força do que a legalidade, numa república historicamente traumatizada pelos golpes e na qual muitos membros da categoria política, independente de partidos, via de regra, não estabelecem um distanciamento muito nítido entre o interesse público e o privado.

Apesar do valor básico da democracia ser a legitimidade, consubstanciada no apoio popular e na representatividade dos governantes, a continuidade da democracia historicamente tem sido quebrada por problemas de desrespeito à legalidade. Expressando essa preocupação, o senador Jefferson Peres afirmou, em entrevista recente (Lago, 2006), que o corte na política brasileira, hoje, não é mais entre a esquerda e a direita, mas entre republicanos e patrimonialistas. Enquanto os republicanos priorizam as disposições constitucionais referentes aos princípios da legalidade, impessoalidade, moralidade e publicidade, que devem reger a administração pública, os patrimonialistas estão, pelo contrário, interessados em confundir o interesse público e o pessoal ou partidário.

\section{Entre o ideal e a realidade}

A democracia é a forma de equacionar a questão da distribuição do poder político na sociedade, como condição para todas as tarefas seguintes. Legitimidade é a palavra-chave desse regime, identificando seu vetor eminentemente político, assentado nas formas universais de aquisição do poder, por delegação da vontade popular. Legalidade 
é o seu lado republicano, seu polo de direito, com ênfase na vigilância, na norma e na responsabilização (accountability). Ambos agem como duas colunas que sustentam o arco da convivência política civilizada. Problemas envolvendo a tensão entre legalidade e legitimidade marcam a instauração democrática brasileira, em contraste com as formulações ideais, salientando sua incompletude. O encaminhamento dos problemas do desenvolvimento, da distribuição da riqueza, das prioridades nacionais depende do aprimoramento da democracia, fortalecendo a representatividade, mas também o tônus republicano do governo, revelado pelo vigor de suas instituições.

Nesse processo, a imprensa tem um papel importante de fiscalização, zelando tanto pela legitimidade quanto pela legalidade do governo, ecoando os interesses dos cidadãos, mas, também, criticando e fiscalizando quando houver evidências de desvios. No entanto, o que uma verificação dos enquadramentos de uma amostra pequena sugeriu foi que os veículos, em certos momentos, parecem tornar-se protagonistas da luta política, assumindo posições sob a forma de enquadramentos não-controvertidos, ou seja, partidarismo.

\section{Referências bibliográficas}

BAKER, C. E. Media, markets and democracy. West Nyack: Cambridge University Press, 2001.

BAQUERO, M. Cultura política participativa e desconsolidação democrática; reflexões sobre o Brasil contemporâneo. São Paulo em Perspectiva. v.15 n.4. São Paulo out./dez. 2001.

BIRCH, A. The concepts and theories of modern democracy. Londres: Routledge, 1993.

BOBBIO, N. O futuro da democracia. São Paulo: Paz e Terra, 2000.

CASTRO SANTOS, M. H. Que democracia? Uma visão conceitual desde a perspectiva dos países em desenvolvimento. Dados. v.44 n.4. Rio de Janeiro, 2001

CHEIBUB, J. A. \& PRZEWORSKI, A. Democracia, eleições e responsabilidade política. Revista Brasileira de Ciências Sociais, São Paulo, v.12, n.35, p.49-61, out. 1997. 
DAHL, R. Sobre a democracia. Brasília: Ed. da Universidade de Brasília, 2001.

DEETZ, S. A. Democracy in an age of corporate colonization developments in communication and the politics of everyday life. Albany: State University of New York Press, 1997.

DINIZ, E. Globalização, reforma do estado e teoria democrática contemporânea. São Paulo em Perspectiva. v.15 n.4. São Paulo, out./dez.2001.

ELSTER, J. 1994. Peças e engrenagens das Ciências Sociais. Rio de Janeiro: Relume-Dumará.

The Market and the Forum: Three Varieties of Political Theory. In: BOHMAN, J. \& REGH, W. (Eds.). Deliberative democracy: essays on reason and politics. Cambridge: MIT, 1997.

A possibilidade da política racional. Revista Brasileira de Ciências Sociais, São Paulo, v.14, n.39, p.14-40, fev. 1999.

ENTMAN, R. M. Framing US Coverage of International News: contrast in narratives of the KAL and Iran Air incidentes. Journal of Communication, 41 (4), p. 6-27, Autumn, 1991.

Framing: toward clarification of a fractured paradigm. Journal of Communication, 43 (4), p. 51-58, Aug., 1993.

KINZO, M. D. Partidos, eleições e democracia no Brasil pós-1985. Revista brasileira de Ciências Sociais. v.19, n.54. São Paulo: fev. 2004.

LAGO, R. No Brasil há excesso de falta de ética. Isto é, n.1932, 1/12/2006, p.7-12.

MARSHALL, T. H. Cidadania, classe social e status. Rio de Janeiro : J. Zahar, 1967.

MIGUEL, L. F. Representação política em 3-D: elementos para uma teoria ampliada da representação política. Revista brasileira de Ciências Sociais. v.18 n.51 São Paulo. fev. 2003.

O’DONNELL, G. Teoria democrática e política comparada. Dados v.42 n.4 Rio de Janeiro, 1999.

REIS, F.W. Democracia, igualdade e identidade. In: PERISSINOTTO, R. M. \& FUKS, M. (Orgs.). Democracia: teoria e prática. Rio de Janeiro: Relume-Dumará, 2003.

REIS, F. W.; CASTRO, M. M. M. de. Democracia, civismo e cinismo: um estudo empírico sobre normas e racionalidade. Revista brasileira de Ciências Sociais. v.16, n.45. São Paulo, fev. 2001.

RHEE, J. W. Strategy and issue frames in election campaign coverage: a social cognitive account on framing effects. Journal of Communication. 47 (3), 1997, Summer, p.26-48. 
RIBEIRO, R. J. A república. São Paulo: Publifolha, 2001. A democracia. São Paulo: Publifolha, 2002.

RODRIGUES, A. T. A democracia como invenção política. Revista brasileira de Ciências Sociais. n.22. Curitiba, jun. 2004.

SALES, C.V. As máscaras da democracia: notas sobre a teoria democrática contemporânea à luz dos eixos dahlsianos. Revista brasileira de Ciências Sociais. n.24. Curitiba, jun.2005.

SARTORI, G. A teoria da democracia revisitada. v.1: o debate contemporâneo. São Paulo: Ática, 1994.

SCHUMPETER, J. A. Capitalismo, socialismo e democracia. Rio de Janeiro: J. Zahar, 1984.

SHEN, F., EDWARDS, H. H. Economic individualism, humanitarism and welfare reform: a value-based account of frame effects. Journal of Communication, 55(4), p.795-808, Dec. 2005.

SOARES, M. C. Análise de enquadramento. In: DUARTE, J., BARROS, A. (Orgs.) Métodos e técnicas de pesquisa em comunicação. São Paulo: Atlas, 2006.

WEBER, M. Economia e sociedade. Brasília: Ed. Universidade de Brasília, 1994.

Ensaios de sociologia. Rio de Janeiro: Livros Técnicos e Científicos, 1982. 



\section{1 \\ A LUTA PELA DEMOCRATIZAÇÃO \\ DOS MEIOS E AS TECNOLOGIAS DIGITAIS}

\section{Introdução}

A discussão sobre políticas democráticas de comunicação é relativamente recente no Brasil. Nas primeiras décadas do século XX, quando foram se disseminando o fonógrafo, o cinema, o rádio, nem sequer a comunicação constituía um campo de estudos próprio, de modo que inexistiam conceitos e teorias que dessem respaldo a uma reflexão sobre o assunto. Sem referências teóricas que servissem de suporte, era muito difícil prever o impacto que os meios teriam futuramente nas sociedades, por isso, até meados do século passado, eles foram sendo incorporados ao dia-a-dia da sociedade como novidades tecnológicas e formas de entretenimento e informação, sem uma discussão ampliada de seu significado ou sobre a importância de políticas públicas para eles. As discussões, à época das primeiras implantações dos meios eletrônicos, ficaram limitadas aos âmbitos político e econômico, tratados na esfera do governo ou dos empresários do ramo, como assunto para círculos fechados, enquanto à sociedade cabia o papel, literalmente, de espectadora.

Apesar de o início da radiodifusão no Brasil ter ocorrido por iniciativa do antropólogo e educador Roquete Pinto, um entusiasta das aplicações educacionais do novo meio, logo os aficionados do 
rádio buscaram patrocínio comercial para as emissoras, como forma de financiamento, dando início à dominância do modelo comercial privatista. Poucos anos depois, houve a instauração do governo autoritário surgido do golpe de 1930. No contexto da chamada Era Vargas, pelo decreto 20.047, de 1931, teve início a tradição brasileira de o governante em exercício fazer concessões de canais de radiodifusão a aliados ou simpatizantes políticos, usando os meios de comunicação como moeda política (Almeida, 1971; Santos, 2004). A televisão, cujas transmissões tiveram início em 1954, desenvolveu-se seguindo o modelo já traçado pelo rádio, como concessão a título precário outorgada pelo presidente da República. As políticas democráticas de comunicação só vieram a ser discutidas na década de 1980, quando os modelos operacionais já estavam consolidados, os canais concedidos e os meios já solidamente estabelecidos, sob a forma de empresas e redes poderosas e influentes.

A tomada de consciência da importância de políticas democráticas de comunicação parece, portanto, extemporânea, na medida em que significa colocar tardiamente uma discussão que não foi feita na época propícia (as primeiras décadas do século XX), procurando reformar modelos vigentes há longo tempo, o que, obviamente, levaria a reações dos grupos proprietários dos meios, aliados às forças políticas. Na atualidade, identificam-se novos fundamentos jurídicos para a reabertura da discussão, apresentando a comunicação como um novo direito social (Ramos, s. d.), e o espectro eletromagnético, que torna as comunicações possíveis, como um recurso natural das nações, tratando-se de um bem coletivo (Schiller, 1976). A percepção contemporânea dos meios como construtores de cenários de representação das realidades políticas, sociais e culturais (Lima, 1988, 1990, 1997) implica que a atividade política se dá num ambiente mediático, por meio do qual os cidadãos acompanham as discussões, deliberações, votações etc., e esse cenário pode ser representado por meio de enquadramentos muito distintos. Portanto, controlar os meios eletrônicos representa uma forma de poder que precisaria ser regulado. As manifestações da cultura, as artes, o cinema ou a música também se tornaram dependentes das comunicações - em 
particular da televisão - para alcançar audiências ampliadas em sociedades com dezenas ou centenas de milhões de pessoas. Desse modo, os concessionários de serviços de radiodifusão não poderiam agir como meros exploradores dos canais, devendo participar da promoção e difusão da cultura e atender a demandas que a sociedade viesse a formular por meio de representantes, de modo a satisfazer ao interesse público.

Os novos meios de comunicação pós-televisão, como a TV a cabo, as rádios comunitárias, a internet e a TV digital surgem num contexto histórico totalmente diverso daquele das primeiras décadas do século XX. Eles alteram o quadro geral das comunicações, instauram modelos operacionais distintos, colocando a discussão sobre a necessidade de rever as investiduras e repactuar marcos legais e direitos, criando a expectativa de novas oportunidades para a reforma da legislação.

\section{Comunicações e poder no Brasil}

Um dos aspectos mais destacados da comunicação no Brasil hoje é a tendência para a oligopolização do controle dos meios, apesar de ela ser expressamente proibida pela Constituição brasileira. A concentração mediática no Brasil ocorre em três níveis: da propriedade, da audiência e da distribuição da verba publicitária pelas agências. Segundo o Intervozes (2005), baseado em dados da Associação Nacional de Jornais (ANJ) de 2002, haveria no país 523 jornais diários, com circulação média de 6,97 milhões de cópias (para uma população de mais de 180 milhões de habitantes), sendo que somente cinco têm relevância nacional. Apenas oito grupos detêm os meios de comunicação mais importantes no Brasil: Globo, RBS, Abril, Bandeirantes, SBT, Record, Folha de S. Paulo e Estado de S. Paulo. O grupo Globo, o mais importante, com cinco emissoras próprias e 108 afiliadas, alcança praticamente a totalidade do território e da população do Brasil, obtendo mais de 50\% da audiência de TV aberta. Dados de 2005 mostravam que a soma das audiências da Rede Globo e do Sistema Brasileiro de Televisão (SBT) constitui 
cerca de 75\% da audiência brasileira de TV aberta. As verbas publicitárias historicamente também têm se concentrado na Rede Globo (Intervozes, 2005).

Além da concentração horizontal da propriedade, ou seja, a posse de redes de um mesmo meio de comunicação, ocorre, em particular na televisão, a concentração vertical, o que significa que a maior parte da produção dos conteúdos é realizada pelas próprias emissoras. Isso se deve à ausência de exigência legal e de cultura empresarial de terceirização da produção por estúdios independentes ou uma abertura para os produtores de filmes locais, como é obrigatório há décadas nos Estados Unidos e na Europa, onde a veiculação de filmes pela TV há muito é considerada a fórmula salvadora das cinematografias nacionais.

Por último, há a chamada propriedade cruzada, representada pelo controle de diversos meios de comunicação, inclusive numa mesma cidade, caracterizando um monopólio da informação. $\mathrm{O}$ grupo Globo, novamente, apresenta-se como o mais destacado exemplo da concentração cruzada, ao deter, além da maior rede de TV do país, jornais, 15 emissoras de rádio, participação nos grupos de televisão por assinatura Net e Sky, a Editora Globo, com 11 títulos de revistas, um portal eletrônico e duas gravadoras (Som Livre e RGE). Em termos de cabodifusão, o grupo detém empresas que produzem conteúdo (como os canais SporTV, GNT, Multishow e GloboNews) e distribuidoras (a operadora Net Brasil), além de participação acionária na empresa que controla toda a rede de cabos e infraestrutura (Net Serviços). Esse complexo vem sendo usado também para oferecer outros serviços, como internet de banda larga (idem). Sobre a concentração mediática no Brasil, escreve Bolaño:

Trata-se de um modelo nacionalista e concentracionista que, ao mesmo tempo em que protege os capitais instalados da concorrência externa, limita a manifestação das expressões locais e o desenvolvimento de um panorama audiovisual diversificado, servindo basicamente aos interesses políticos e econômicos hegemônicos que se articulam no seu interior. Assim, a inexistência de regras anti- 
monopolistas, como aquelas relativas à propriedade cruzada e concentração multimídia, evidencia menos um suposto liberalismo do modelo do que a existência de uma espécie de capitalismo selvagem por parte de grupos familiares e oligarquias locais e nacionais que detêm o privilégio da exploração privada desse bem público que é o espectro de frequências, protegidos por uma lei criada sob medida para servir aos seus interesses particulares (2003, p.35).

Na maioria dos estados brasileiros, os grupos que controlam regionalmente a mídia estão diretamente ligados às oligarquias regionais. Exemplos notórios são os dos estados da Bahia, no qual a radiodifusão é controlada direta ou indiretamente por Antonio Carlos Magalhães, e o do Maranhão, onde o controle é da família Sarney. Essa situação vem sendo denominada "coronelismo eletrônico", numa adjetivação à expressão "coronelismo" proposta por Leal (1997) em 1949 para referir-se à troca de favores entre o poder público e os chefes políticos locais, geralmente proprietários de terras, origem do mandonismo, do filhotismo, do falseamento do voto e da desorganização dos serviços públicos locais. Para Santos e Caparelli (2005), os coronéis políticos de outrora se transformaram nos coronéis eletrônicos de hoje, usando, como instrumento de poder, em vez da propriedade rural, as estações geradoras e retransmissoras de radiodifusão. Esses autores consideram o coronelismo eletrônico uma forma de clientelismo político, que se dá entre os detentores do poder político e os proprietários de canais de televisão, bloqueando a diversidade da televisão e priorizando os interesses particulares, em vez do interesse público. Uma base de dados construída por Suzy dos Santos (apud Santos \& Caparelli, 2005) permitiu elaborar uma tabela do número de outorgas controladas por políticos, na qual se computam $33,6 \%$ das geradoras de propriedade de pessoas que exercem ou exerceram mandato eleitoral. Mas em alguns estados esse percentual é ainda maior, como a Bahia, com 57\%; o Maranhão, com 72\%; o Ceará, com 55\%; o Rio Grande do Norte, com 85\%.

A presença de políticos no controle dos grupos de comunicação acaba sendo também uma barreira ao desenvolvimento de uma 
legislação que vise evitar a concentração mediática. Na verdade, muitos parlamentares são proprietários ou sócios de veículos de radiodifusão ou, então, têm o controle de veículos registrados em nome de amigos ou parentes. Dessa maneira, observa o Intervozes, os proprietários dos meios, na condição de parlamentares, legislam em seu interesse.

As relações entre o poder político e a radiodifusão não se limitam ao parlamento. O poder Executivo, também, lançou mão da atribuição legal para a concessão de serviços de radiodifusão, com a finalidade de obter apoios políticos. O caso mais conhecido é o que foi protagonizado pelo ministro das Comunicações Antonio Carlos Magalhães, durante o governo Sarney, em cuja gestão foram cedidas centenas de canais de rádios FM a políticos, visando à obtenção de apoio para votação dos cinco anos de duração para o mandato do presidente José Sarney. Segundo Motter (apud Almeida, 2002), nunca na história brasileira um governo distribuiu tantos canais em tão pouco tempo, nem fez uso político desse fato de forma tão explícita. De 15 de março de 1985 a 5 de outubro de 1988, quando foi promulgada a Constituição, foram concedidas 1.028 emissoras de rádio e tevê, sendo 539 (52\%) distribuídas nos últimos nove meses da Constituinte, a grande maioria destinada aos que votaram no mandato de cinco anos para o presidente Sarney. O ministro, proprietário da TV Bahia, valeu-se, também, da sua condição para montar um império mediático na Bahia, fazendo concessões de emissoras de televisão, de rádio e retransmissoras de TV a aliados políticos e membros de sua família (Almeida, 2002). A partir dessa posição de força, Magalhães pôde atacar livremente seus adversários, como o governador Waldir Pires, sem sofrer contra-ataques. Com isso, Magalhães estava seguindo ao pé da letra o lema atribuído a ele mesmo, em 1975: "quem tem televisão, rádio e jornal estará sempre no poder" (apud Almeida, 2002).

Mais tarde, durante a gestão de Fernando Henrique Cardoso no primeiro mandato, em dezembro de 1996, o ministro das Comunicações, Sérgio Mota, autorizaria concessões de cerca de quatrocentas retransmissoras de TV - na maioria para políticos - à época da vota- 
ção da emenda da reeleição do presidente em exercício. As retransmissoras concedidas estavam habilitadas à produção de conteúdo, ou seja, na prática, podiam funcionar como emissoras de TV, sendo que a outorga dependia apenas de uma permissão do Executivo, facilidade que tornava possível a cessão sem passar pelo Congresso (Costa \& Brener, 1997).

Ainda no primeiro mandato de Cardoso, deu-se a promulgação da Lei Geral de Telecomunicações, em 1997, que privatizou a telefonia e criou a Agência Nacional de Telecomunicações (Anatel). Esta última teria as funções de regular a telefonia, anteriormente de responsabilidade do Ministério das Comunicações, e a cabodifusão, mas não alcançaria a radiodifusão, que permaneceu regulada pelo antigo Código Brasileiro de Telecomunicações. Ao distinguir a regulamentação entre telecomunicações e radiodifusão, a nova lei rompeu a unidade do Código Brasileiro de Telecomunicações, de 1962, permitindo a reforma das telecomunicações, ao mesmo tempo em que deixava intacta a parte referente ao rádio e televisão, controlados por grupos políticos fortemente representados no Congresso Nacional (Bolaño, 2003). A radiodifusão conseguiu, dessa forma, assegurar a continuidade de sua autonomia perante os poderes e controles da sociedade, ao situar-se como um serviço singular, constitucionalmente estabelecido e não como serviço de telecomunicações, como ocorre nos demais países (Ramos, 1997).

Quanto maior a concentração dos meios de comunicação, menor a quantidade de grupos que podem ter acesso a eles, resultando na redução virtual da liberdade de expressão da sociedade, cujo exercício efetivo fica restrito às famílias detentoras dos oligopólios de meios existentes. No entanto, todas as vezes que se discute a necessidade de regulamentação das comunicações, os empresários do setor se defendem com o argumento de ameaças de restrições à liberdade de expressão, de censura dos meios, recusando a discussão. Exemplo recente dessa postura foi o tratamento dado em 2004 aos projetos de criação do Conselho Federal de Jornalismo e da Agência Nacional do Cinema e do Audiovisual, que sofreram pressão permanente até serem arquivados, sem avaliação do mérito. 


\section{A luta pela democratização da comunicação}

Ramos (s. d.) considera que o "marco liberal moderno para a discussão da relação entre comunicação e democracia é a Primeira Emenda à Constituição americana", que estabelece que não se fariam leis restringindo a liberdade de expressão e de imprensa. Para o autor, esse princípio chegaria ao século XX amparado pelo conceito de "livre fluxo das ideias", dedução do liberalismo econômico. Segundo esse conceito, qualquer tentativa de submeter os meios de comunicação a regulação governamental passaria a ser tratado como uma forma de cerceamento ou de censura.

Ao longo do século passado, porém, a visão liberal, que identificava o livre fluxo de ideias e informações com democracia, começou a sofrer questionamentos, que alcançariam, na década de 1960, a Unesco. O impacto e as perspectivas trazidas pelo desenvolvimento da televisão foram decisivos para o reconhecimento da importância da comunicação para o desenvolvimento e a educação. Surge, então, na década de 1970, um debate internacional sobre políticas nacionais de comunicação, especialmente entre autores e políticos socialistas, que atribuíam um papel importante à ação do Estado na produção de mudanças sociais e no desenvolvimento da democracia. Essas ideias provocariam uma reação dos liberais, teoricamente fundamentados no conceito de livre fluxo de informação, que eram minoria na Unesco, contra países do então chamado Terceiro Mundo, na circunstância do auge da Guerra Fria entre Estados Unidos e União Soviética.

Nesse contexto de confrontação, a Unesco instalou uma comissão, presidida por Sean McBride, para discutir a questão das aplicações sociais dos meios de comunicação. Ao final dos trabalhos, a comissão divulgou o chamado relatório McBride, contemplando as posições mais progressistas sobre o papel dos meios nas sociedades contemporâneas e criticando o fato de sua destinação meramente mercadológica. Esse resultado levaria os Estados Unidos (o maior financiador da Unesco), a Inglaterra e o Japão a se retirarem da organização, como forma de extinguir, por meio do estrangulamento econômico da agência, as discussões sobre as políticas públicas para os meios de comunicação. 
Santos (1995) considera que a primeira fase do movimento pela democratização da comunicação no Brasil, a qual denominou "de resistência”, teria tido início após o golpe de $1964 .{ }^{1}$ Para o autor, até então a comunicação mediática não estava colocada como uma questão política, uma vez que o tema nem constava das propostas dos setores progressistas nem das chamadas reformas de base do presidente Goulart. Não havia até aquele momento um sistema de comunicação de massa consolidado no país e a maioria da sociedade brasileira ainda era rural. Mas a partir da segunda metade da década de 1960, estrutura-se o sistema brasileiro de comunicação de massa, liderado pela modernização das telecomunicações realizadas pelos governos militares, a partir dos pressupostos da doutrina de segurança militar. Escreve o autor:

Os governos militares, de 1964 a 1985, tinham muita clareza sobre o papel político da comunicação mediática e implementaram políticas para o desenvolvimento de jornais, rádio, televisão e informática. Aos grandes jornais diários concederam empréstimos subsidiados para construção de novas sedes e modernos parques gráficos, além de lhes destinarem vultosas verbas publicitárias.

No campo das telecomunicações, infraestrutura básica para o rádio e a televisão, criou-se a Embratel, em 1965 e o Ministério das Comunicações e o Conselho Nacional de Telecomunicações, em 1967; instalou-se a rede nacional de microondas e o sistema de transmissão via satélite e transformou-se o Departamento de Correios e Telégrafos em empresa pública, em 1969; em 1972, criou-se a Telebrás e implantou-se a televisão em cores. De acordo com a doutrina de segurança nacional, ideologia oficial do regime militar, a comunicação, ao lado dos poderes militar, político e econômico, seria um dos quatro pilares básicos do poder nacional para se atingir

1 A nosso ver, recuar a periodização dos movimentos pela democratização mediática até o regime militar de 1964 parece ser o resultado de um olhar retrospectivo, à luz do que aconteceu a partir dos anos 1980, quando tem início propriamente a luta por políticas de comunicação. 
a integração nacional e a integração social. Os meios de comunicação foram fundamentais para a modernização-conservadora, empreendida no período, e para a legitimação, ainda que precária, do regime. (Santos, 1995).

Ao lado dessas ações no sentido de modernizar a comunicação, os governos militares implantam formas de censura à imprensa e às artes. Têm início, então, movimentos de resistência em espaços sociais mais restritos, como as Comunidades Eclesiais de Base (CEBs), entidades profissionais, organizações e partidos clandestinos, utilizando meios de comunicação de baixa tecnologia, como jornais mimeografados e panfletos, de circulação restrita. É nesse contexto de repressão política que vão surgir, a partir de 1969, as publicações alternativas com qualidade gráfica e editorial como Pasquim, Opinião, Coojornal, Movimento e outros, discutindo temas que não figuravam na grande imprensa. Mas esses veículos também eram gravemente afetados pela repressão e censura, amargando ameaças e prejuízos econômicos. Nos anos 1970, a luta pelas liberdades e contra a censura acabaria envolvendo diversas organizações da sociedade civil, como a Federação Nacional dos Jornalistas (Fenaj), a Ordem dos Advogados do Brasil (OAB), a Associação Brasileira de Imprensa (ABI), a Conferência Nacional dos Bispos do Brasil (CNBB).

A segunda fase do movimento pela democratização da comunicação, para Santos, é a que ele denomina "de conquistas", tendo como marco de início o VII Congresso da Associação Brasileira de Ensino e Pesquisa de Comunicação, realizado em 1983, em Florianópolis, quando é proposta a criação da Frente Nacional de Lutas por Políticas Democráticas de Comunicação. Para Santos, tratava-se de um salto qualitativo dos setores organizados da sociedade, em comparação ao movimento de resistência anterior, pois, então, eram vislumbradas possibilidades de transformações institucionais dos meios de comunicação, a partir do plano jurídico, considerado fundamental para mudanças estruturais no sistema de comunicação.

No ano seguinte, é criada, em Brasília, a Frente Nacional de Lutas por Políticas Democráticas de Comunicação, com a participação 
de parlamentares e dezenas de entidades ligadas à comunicação e à cultura, a qual formula uma série de propostas de reformas democratizantes da comunicação, envolvendo o rádio, a televisão, a imprensa, o cinema, a publicidade, tecnologias de comunicação, liberdade de informação, educação e comunicação popular. Era a primeira vez que entidades da sociedade civil organizavam uma frente nacional para tratar especificamente da comunicação, propondo em seu manifesto de constituição "mudanças profundas na estrutura do modelo da comunicação social", com o objetivo de que a comunicação passasse a responder às expectativas da sociedade. Naquele ano, foi lançado pela Fenaj e outras entidades a brochura Proposta para uma política democrática de telecomunicações e de comunicação social, enquanto o Centro de Comunicação e Cultura (CEC) de Brasília divulgava o documento A transição política e a democratização da comunicação social. Os jornais noticiavam que profissionais ligados ao MDB de São Paulo preparavam uma proposta para as comunicações da Nova República.

No ano seguinte, o Centro Brasileiro de Estudos Latino-Americanos (Cebela) divulgava o documento Proposta de uma política nacional de comunicação para o Brasil. Esses documentos defendiam

a criação de um sistema democrático de comunicação no Brasil, o fim dos monopólios, a criação de um Conselho Nacional de Comunicação Social, com a participação da sociedade civil, o reconhecimento do direito à comunicação como um novo direito humano, e a liberdade irrestrita de expressão. (Santos, 1995, p.7)

As críticas e propostas elaboradas na época eram bem abrangentes, incluindo os meios impressos, o cinema, o rádio, mas, principalmente, a televisão, marcada pela concentração de canais, empresas e de audiência, indicando a existência de um oligopólio privado, com operação em rede nacional não-limitada significativamente, mediante critérios que induzissem à regionalização da produção. Observava-se também a predominância de canais comerciais privados, a concentração de fontes geradoras e emissoras da maior parte 
da programação no Rio e em São Paulo. Pela primeira vez, criticavase a inexistência de instâncias por meio das quais fosse viabilizada a participação dos profissionais e do público nas orientações do sistema. Criticava-se também o intenso uso do sistema de televisão por políticos, a atuação política dos detentores das concessões, a concessão pelo governo de benefícios especiais às emissoras, em troca de seu apoio político. O movimento entendia que os concessionários de radiodifusão deveriam pagar pela exploração econômica da concessão, gerando recursos para a criação de um fundo que financiaria emissoras públicas (não-estatais), não-comerciais, de forma a criar uma diversidade de formas de radiodifusão: defendia a pluralidade de modelos de radiodifusão, em vez da opção pelo modelo privado comercial, exclusivamente. Propunha que a programação da radiodifusão estabelecesse horários de transmissão nacional, regional e local, de forma a representar a heterogeneidade de temas, gostos, interesses das audiências.

Eram sugeridas diversas medidas para alterar o quadro da radiodifusão, como a proibição de que um concessionário acumulasse mais de uma concessão para radiodifusão; a prioridade nas concessões para entidades sem fins lucrativos; a limitação da abrangência geográfica das concessões; a limitação da potência das emissoras, a fim de regionalizar as produções e diversificá-las; a reserva de mercado para programas de estúdios independentes; o estabelecimento de limites máximos para a exibição de programas produzidos em outros estados e fora do país e de limites mínimos (reserva de mercado) para a produção local e regional; a orientação da atuação das emissoras por conselhos estaduais e municipais democraticamente eleitos e socialmente representativos.

Vivia-se um clima de otimismo, com a convocação da Assembleia Nacional Constituinte, havendo a expectativa de que a nova Constituição brasileira fosse um instrumento capaz levar a uma profunda democratização da Comunicação Social. Centenas de propostas renovadoras eram encaminhadas à Subcomissão de Ciência, Tecnologia e Comunicação e à Comissão da Família, da Educação, Cultura e Esportes, da Ciência e Tecnologia e da Comunicação, preparatórias 
dos textos para debate no plenário da Constituinte, enquanto a imprensa noticiava que Roberto Marinho encarregara algumas pessoas de acompanhar os trabalhos. Ao final de meses de discussão, na sessão de votação do texto da relatora, deputada Cristina Tavares, os deputados ligados aos meios de comunicação derrubaram o relatório apresentado pela mesa, sem apresentar substitutivo, fazendo com que a comissão de Comunicação fosse a única a não ter um documento para encaminhar ao plenário da Constituinte.

Apesar dessa reação, algumas propostas dos parlamentares ligados aos movimentos sociais das comunicações acabaram sendo apresentadas nas discussões plenárias da Constituinte, votadas e incorporadas pela Constituição. Entre elas estão a proibição de restrições à manifestação do pensamento, à criação, à expressão e à informação; a proibição de monopólios e oligopólios de meios de Comunicação Social; a regionalização da produção cultural, artística e jornalística; a criação do Conselho de Comunicação Social, ligado ao Senado Federal, com participação de representantes da sociedade. Essas conquistas, muitas vezes, ficaram no papel, como declarações retóricas e não como leis que precisariam ser regulamentadas e cumpridas. O caso mais célebre é o do Conselho de Comunicação Social, que levou 14 anos para ser instalado, após negociações e gestões dos setores progressistas, mas que tem uma atuação muito limitada pela legislação que regulamentou sua criação (Roldão, s. d.).

A terceira fase da luta, caracterizada por Santos como "de indefinições”, teria iniciado em 1989, com o I Encontro Nacional de Rádios Livres, quando foi criado o Coletivo Nacional de Rádios Livres. No ano seguinte, no Rio de Janeiro, é lançado o Comitê pela Democratização dos Meios de Comunicação, na sede da ABI, com o apoio de dezenas de entidades sindicais e da sociedade civil. Diversos comitês estaduais pela democratização da comunicação começam a se instalar em 1990, resultando em junho de 1991 na criação do Fórum Nacional pela Democratização da Comunicação, organizado nos estados por comitês instalados pelos sindicatos locais de jornalistas e radialistas, com a coordenação nacional principalmente a cargo da Federação Nacional dos Jornalistas (Fenaj) e da Federação Nacional 
dos Trabalhadores em Emissoras de Rádio e Televisão (Fitert). Nos comitês era constante a presença de acadêmicos e estudantes de comunicação, além dos profissionais (Ramos, s. d.).

Nesse mesmo ano, o Fórum mobiliza-se e impede a tentativa do governo de conceder a exploração dos serviços de cabodifusão por meio de portaria ministerial. Segundo o relato de Ramos (s. d.), os representantes do Fórum salientaram que, pelos impactos que a TV a cabo produziria e por tratar-se de um serviço com características semelhantes às da radiodifusão, sua implantação deveria passar pelo Congresso Nacional, sob a forma de lei, em vez de ser normatizada por uma simples portaria. Após anos de negociações entre o Fórum, o governo e representantes empresariais, a lei da cabodifusão foi finalmente sancionada em dezembro de 1994. Na avaliação de Ramos (s. d.), o texto apresenta mecanismos inéditos na legislação das comunicações brasileiras, destacando-se o estatuto público atribuído às redes de TV a cabo, o que permitiu, entre outros dispositivos, a distribuição gratuita de canais disponibilizados para o Senado e a Câmara Federal, Assembleias Legislativas e Câmaras de Vereadores, instituições universitárias e de ensino superior, instituições de caráter educativo-cultural e entidades ou instituições comunitárias. Segundo o autor, a lei assegurou que as redes de cabodifusão não fossem dedicadas, integrando-as ao sistema nacional de telecomunicações, instaurando um estatuto público moderno e democrático para as novas redes privadas de banda larga, subordinadas à Agência Nacional de Telecomunicações (Anatel), o que assegura um controle público sobre elas.

Um dos pioneiros das mobilizações e um dos criadores do Fórum Nacional pela Democratização da Comunicação, Daniel Hertz, escreveu em 1992 que se procurava superar o oposicionismo e a linguagem de impotência que até então marcavam as posições do movimento. Para ele, a luta pela democratização da comunicação não deveria ficar à espera do momento de uma conquista do Estado ou em que se produziria uma Globo com sinal contrário, com a substituição do mal pelo bem. Em vez disso, o Fórum revindicava, com sua participação na redação da lei da cabodifusão, o estabelecimento 
de novas relações políticas com os meios de comunicação, em torno da ideia chave de controle público dos meios:

A ideia de democratização, sob este enfoque, passa a ser encarada como processo: nenhuma conquista é pequena demais para ser desprezada e nenhuma vitória poderá ter a dimensão de resultado final. Os programas fechados e finalistas são substituídos por uma conduta orientada por objetivos estratégicos. Assim fundamentado, o Fórum preocupa-se, imediatamente, menos com a socialização da propriedade e mais com o controle do conteúdo da programação.

Apesar da vitória, Ramos (s. d.) ressaltaria que após anos de intensa atividade na questão da lei da cabodifusão, "a capacidade de mobilização e a articulação pragmática, que caracterizou a ação do Fórum Nacional pela Democratização da Comunicação no início dos anos 90, arrefeceu ao ponto de desaparecer neste final de década”. Em 2003, o Comitê Rio, em carta ao FNDC, avaliou que o Fórum não teria conseguido colocar para a sociedade civil a importância da luta pela democratização da comunicação social, levando à desmobilização do Fórum em 1997.

\section{As tecnologias digitais}

O novo milênio trouxe um panorama bastante diferente para as perspectivas de democratização dos meios, especialmente em razão das tecnologias de digitalização das comunicações. A internet, lançada no Brasil em 1995, disseminou-se, em poucos anos, por milhões de terminais, em residências, escritórios, escolas e bibliotecas. Embora não tenha sido objeto das lutas anteriores, a internet teve um impacto generalizado na abertura da comunicação, por meio da disponibilização de informações a baixo custo por sites pessoais, organizações, movimentos e entidades, de forma livre e independente. Assim, do ponto de vista social, a internet é um estímulo ao protagonismo, à pluralidade, diversidade, favorecendo a crítica e disseminando-a. 
Além de suportar recursos de multimeios, que a tornam um protótipo da convergência digital, a rede das redes de computadores, com abrangência planetária, propiciou o aumento da oferta de informação gratuita em todos os setores e viabilizou a emergência da interatividade em diversos graus. Os blogs, o jornalismo on-line, as páginas dos movimentos sociais são algumas das novas possibilidades comunicativas críticas e alternativas que revelam a internet como um novíssimo protótipo de comunicação, cujo princípio é o da interatividade. Com sua implantação, a discussão deslocou-se para as políticas de inclusão digital, visando estender a rede às maiorias, como condição de efetivação do seu potencial democratizante, para que o fosso tecnológico não se alargue entre ricos e pobres, trazendo mais desvantagens ainda para estes últimos. Apesar de tudo, a internet não é a utopia finalmente realizada, pois os grandes fornecedores de informações tradicionais (revistas, jornais e redes de TV) expandiram seus negócios para o chamado ciberespaço, no qual dominam como fornecedores de conteúdo e em termos de número de acessos.

Houve, em seguida, o decreto da criação da televisão digital, que renovou o ímpeto da mobilização das entidades por mudanças na radiodifusão, uma vez que essa tecnologia implica uma transformação radical das transmissões de TV, permitindo a multiplicação do número de canais disponíveis, a TV de alta definição, interatividade, entre outras características. A sociedade brasileira foi subitamente colocada em face da adoção de uma nova tecnologia de comunicação que abre inúmeras possibilidades culturais, educacionais e de cidadania. Inúmeras decisões precisavam ser tomadas para configurar um modelo de TV digital, implicando questões tecnológicas, mas, sobretudo, a adoção de políticas de comunicação, com repercussões de natureza social, cultural e econômica. Nesse processo, de um lado estão as possibilidades de renovação do quadro atual, com a abertura do uso do espectro, e do outro lado está o interesse corporativo das redes, cujo maior objetivo é não mudar em nada o controle sobre a fatia do espectro eletromagnético de que dispunham. Para a decisão, o governo escolheu 2006, sintomaticamente, um ano eleitoral, embora a opinião dos especialistas é que deveria haver mais tempo para maio- 
res definições, mesmo porque a implantação da TV digital não estava em estágio avançado em nenhum lugar do mundo (Intervozes, 2006).

Para o Intervozes - Coletivo Brasileiro de Comunicação Social - a TV digital deveria possibilitar a entrada de novos atores, especialmente de caráter público, a fim de garantir a democracia efetiva e a liberdade de expressão e pensamento, em sua dimensão coletiva, estabelecendo um sistema público de comunicação, sem fins lucrativos e sob o controle da sociedade. A melhor maneira de estimular a migração para a TV digital, segundo o Intervozes, seria por meio da criação de novos canais, e não a transmissão em alta definição, que exige receptores de custo inacessível para a maioria da audiência de TV aberta no Brasil.

Para Gustavo Gindre, ${ }^{2}$ integrante do Conselho Consultivo do Sistema Brasileiro de TV Digital e militante histórico pela democratização da comunicação, o envolvimento das entidades na discussão da TV digital foi enorme, com atividades em todo país, todas as semanas, sob a forma de debates ou audiências públicas nas capitais. O Ministério Público se envolveu, foi criada uma frente nacional com dezenas de entidades, foram redigidas propostas e duas revistas foram impressas sobre o tema. No entanto, o coordenador do Intervozes, lamenta a tendência em haver pouco ganho para a democratização da comunicação com a transição para a TV digital. Para Gindre, deverá ser mantida, por exemplo, "a política de conceder um canal inteiro de $6 \mathrm{MHz}$ para cada emissora (um espaço que antes abrigava apenas uma única programação e que agora pode levar até oito programações simultaneamente)".

Para a Frente Nacional por um Sistema Democrático de Rádio e TV Digital, "o anúncio da decisão a favor da adoção do padrão de modulação japonês (ISDB), no apagar das luzes do primeiro mandato do presidente Lula e em plena Copa do Mundo" foi um erro histórico, mostrando que "o governo brasileiro, infelizmente - e à semelhança dos anteriores -, seguirá tratando a comunicação exclusivamente como uma moeda de troca política”. O Fórum critica a

2 Eme-mail a este autor. 
falta de transparência do processo decisório, dizendo que a adoção do ISDB descartou as alternativas tecnológicas desenvolvidas no Brasil. Para o Fórum, a adoção da tecnologia japonesa põe em risco a possibilidade de o Brasil se tornar um grande produtor mundial de conteúdos multimeios, para o que seria necessário democratizar o espectro e adotar tecnologias baseadas em software livre para a criação e reprodução desses conteúdos internacionalmente.

As manobras das redes de televisão, em particular a Rede Globo, visando dirigir as deliberações sobre a TV digital, revelam como é assimétrica a relação de forças entre o movimento democrático da sociedade civil e as redes de TV. Ao longo da história das lutas pela democratização dos meios no Brasil, o que se percebe é o predomínio das corporações mediáticas na produção legislativa e nas decisões governamentais. Mas o caso da TV digital representou uma radicalização dessa tendência, com o processo de transição sendo conduzido por um ex-funcionário da própria Rede Globo, na condição de ministro das Comunicações.

\section{Considerações finais do capítulo}

Iniciada, efetivamente, na década de 1980, a luta pela democratização da comunicação representou uma tomada de consciência de que a configuração dos meios de comunicação eletrônicos em um país é resultado de decisões políticas de instâncias governamentais e da dinâmica legislativa, influenciadas pelos sistemas de pressão de atores bem posicionados no momento em que se instalam os meios. Apesar de vários revezes sofridos pelos movimentos sociais, a Constituição de 1988 incorporou alguns princípios e instrumentos democratizantes, os quais, ao longo do tempo, se tornaram meramente declaratórios, não adquirindo vigência efetiva. Posteriormente, a produção da legislação da TV a cabo contou com a participação da sociedade, por meio do FNDC, sem limitar o predomínio do grupo Globo no setor. Apesar de tudo, se, por um lado, a cabodifusão, dado seu caráter de operação transnacional, apresenta uma desnacionalização 
da programação, por meio dos canais de filmes e desenhos animados norte-americanos, por outro, a vitória do FNDC viabilizou a criação dos canais legislativos, universitários e comunitários. É preciso lembrar, por último, que a TV a cabo distribui sua programação para um segmento estreito da audiência, formado por quatro milhões de residências, incluindo todas as operadoras, num universo de 45 milhões de residências com televisão.

A TV digital trouxe uma nova e vigorosa retomada do movimento social pela democratização mediática, mas as forças de pressão corporativas foram vencedoras. Ao lograrem a manutenção de $6 \mathrm{MHz}$ para suas concessões, as redes mantêm a posse do espectro eletromagnético como usucapião, ou seja, direito adquirido, renovando o que Gindre denominou de "política dos fatos consumados", que tem mais poder do que as leis. Grandes corporações, solidamente estabelecidas do ponto de vista econômico e financeiro, têm quadros de engenheiros e advogados, desfrutam de articulações políticas diretas e privilegiadas com o governo, por meio do Ministério das Comunicações, de modo que suas vantagens, no confronto com os movimentos sociais pelas definições dos sistemas, são muito grandes, fazendo com que sejam levados em conta prioritariamente seus objetivos, em detrimento das possibilidades culturais e educativas da TV digital para a sociedade.

Na trajetória do movimento de democratização, observa-se, por conseguinte, um padrão: o establishment da radiodifusão manteve-se imponderável em face das lutas, revelou a capacidade de perpetuarse inalterável, mantendo a posição dos grupos proprietários. Já as inovações tecnológicas no campo das redes de computadores é que criaram a situação inédita representada pela internet, abrindo caminhos promissores à maior participação social na comunicação.

O discurso dos líderes do movimento pela comunicação democrática mudou desde 1980, com a experiência da participação nas discussões sobre as novas tecnologias. Ao contrário da perspectiva de uma transformação radical da comunicação brasileira, como aparece nos documentos dos anos 1980, ecoando as posições do relatório McBride, alguns discursos adotam, hoje, uma dose de realismo político 
e econômico, ao mesmo tempo em que os militantes revelam grande domínio dos aspectos técnicos e legais das questões. Admite-se, hoje, informalmente, que certo grau de concentração, ou de tamanho mínimo, é necessário à atividade da televisão, em face dos custos de produção audiovisual, da necessidade de escala de produção e, também, para viabilizar a competitividade no mercado mundial de conteúdos. Em lugar da fragmentação das redes de comunicação, passou-se a defender, cada vez mais fortemente, a necessidade de regulamentação democrática da atividade de radiodifusão, visando ao bem comum e ao pluralismo, bem como o combate da barganha de concessões e favores em troca de apoio político.

Do ponto de vista da sociedade - encarada pelos meios como audiência e consumidora de serviços, novidades tecnológicas e entretenimento -, ao longo desse tempo não chegou a existir mobilização pela democratização mediática, a qual abrangeu especificamente as categorias profissionais da comunicação, professores e estudantes universitários de Comunicação Social. Colocada diante de questões que envolvem princípios teóricos e aspectos técnicos, não dominados pela maioria das pessoas, num país em que a comunicação sempre foi controlada por poucos grupos, a sociedade foi limitada a assistir a implantação de novos meios de comunicação como resultado de decisões tomadas, quase sempre, em gabinetes acessíveis apenas a empresários.

A grande revolução no panorama brasileiro (e, também, mundial) das comunicações foi provocada pela internet, apesar de sua precoce tomada pela publicidade e pelo mercado. A rede mundial de computadores, ao viabilizar a digitalização de qualquer informação (escrita, fotográfica, sonora, cinematográfica), apresenta-se como um protótipo da convergência digital, veiculando textos, imagens, vídeos, música. Ela permite também a correspondência individualizada, a formação de comunidades, as páginas pessoais, os blogs jornalísticos, trazendo novas possibilidades de uso a baixo custo pelo ativismo social, cultural e político. O paradoxo da internet é que a facilidade de disponibilização das informações não garante, necessariamente, acesso pelos usuários, o qual depende de estratégias mercadológicas 
e promocionais que não estão geralmente ao alcance das iniciativas de caráter não-comercial. Essa limitação redunda na reprodução das desigualdades: a hegemonia das empresas do mercado real persiste no mundo virtual.

As lutas pela democratização da comunicação mostram que, dada a grande concentração do poder político na sociedade brasileira, contrário a qualquer mudança, para democratizar os meios é preciso lutar para democratizar a sociedade.

\section{Referências bibliográficas}

ALMEIDA, J. de. Oligarquia, mídia e dominação política na Bahia: a rede carlista de televisão e rádio. São Carlos, 2002.Dissertação de Mestrado - UFSCAR.

ALMEIDA, M. A comunicação de massa no Brasil. Belo Horizonte: Ed. Júpiter, 1971.

BOLAÑO, C. R. S. Políticas de comunicação e economia política das telecomunicações no Brasil. Convergência, regionalização e reforma. 2.ed. Aracaju: Universidade Federal de Sergipe, 2003.

BOLAÑO, C. R. S., BRITTOS, V. C. (Org.). Rede Globo: 40 anos de poder e hegemonia. $1^{a}$ ed. São Paulo: Paulus, 2005.

COSTA, S., BRENER, J. Coronelismo eletrônico: o governo Fernando Henrique e o novo capítulo de uma velha história. Comunicação e Política, Rio de Janeiro, v.4, n.2, nova série, maio-ago., 1997.

FRENTE NACIONAL POR UM SISTEMA DEMOCRÁTICO DE RÁDIO E TV DIGITAL. Governo comete um erro histórico. Observatório da Imprensa. ANO 11 - n. 387. Disponível em http://observatorio. ultimosegundo.ig.com.br/artigos.asp?cod=387TVQ002.

HERTZ, D. Luta pela democratização da comunicação com novos rumos. São Bernardo do Campo: Intercom, 1992. Mimeo.

INTERVOZES. Tv digital: princípios e propostas para uma transição baseada no interesse público. Rio de Janeiro: Coletivo Brasil de Comunicação Social, 2006. Disponível em www.abranet.org.br/doc/ tv-digital-intervozes.pdf Acesso em 18/02/2006.

INTERVOZES. TV digital. Suplemento de Caros amigos, Ano X, n.111, junho 2006.

EAL, V. N. Coronelismo, enxada e voto: o município e o regime representativo no Brasil. Rio de Janeiro, Nova Fronteira, 1997. 
LIMA, V. A. De Televisão e política: hipótese sobre a eleição presidencial de 1989. In: Comunicação e política. n.11, abr.-jun.1990. p.29-54.

State, television and political power in Brasil. Critical studies in mass communication.v. 5, n.2, 1988.

Comunicações, política e democracia. In: TRINDADE, A. A. C. e CASTRO, M. F. A sociedade democrática no final do século. Brasília: Paralelo 15, 1997.

RAMOS, M. C. Televisão a cabo no Brasil: Desestatização, reprivatização e controle público. Disponível em: http://www.intexto.ufrgs.br/vln4/av1n4a2.html.

A força de um aparelho privado de hegemonia. In: BOLAÑO, C. R. S., BRITTOS, V. C. (Orgs.). Rede Globo: 40 anos de poder e hegemonia. $1^{\text {a }}$ ed. São Paulo: Paulus, 2005. p.57-76.

Uma nova legislação para as comunicações brasileiras e o paradoxo da radiodifusão. Tendências XXI, II(2), 1997. p.176-82. Lisboa. Disponível em: http://www.unb.br/fac/publicacoes/murilo/index.htm.

ROLDÃO, C. G. Conselho de Comunicação Social: um instrumento para a democratização da comunicação? Disponível em http://reposcom. portcom.intercom.org.br/handle/1904/17920. Acesso em 29/06/2006.

SANTOS, J. M. A democratização da comunicação nos discursos da sociedade civil brasileira: 1974-1994. Ordem/Desordem, n.12, p.9-16, ago. Belo Horizonte, 1995.

SANTOS, S. Uma convergência divergente: a centralidade da TV aberta no setor audiovisual brasileiro. 270p. Salvador, 2004. Tese de doutoramento - Universidade Federal da Bahia.

SANTOS, S., CAPPARELLI, S. Coronelismo, radiodifusão e voto: a nova face de um velho conceito. In: BOLAÑO, C. R. S., BRITTOS, V. C. (Orgs.). Rede Globo: 40 anos de poder e hegemonia. $1^{\text {a }}$ ed. São Paulo: Paulus, 2005.p.77-101.

SCHILLER, H. O império norte-americano das comunicações. Petrópolis: Vozes, 1976. 


\section{Parte IV}

\section{BALANÇO \& PERSPECTIVAS}





\section{2 \\ O JORNALISMO NA CONSTRUÇÃO DA ESFERA PÚBLICA DEMOCRÁTICA}

Os textos reunidos neste volume abordaram assuntos diversos, mas eles podem ser vistos como momentos de um grande processo social de construção das representações. Esse processo parte dos acontecimentos, temas e controvérsias que são retoricamente construídos pela comunicação mediática, em especial pelo jornalismo, oferecendo enquadramentos concorrenciais nos debates que constroem a esfera pública, entendida como o território da discussão livre entre os cidadãos sobre questões de interesse comum, a arena na qual se tomam e se justificam as decisões políticas (Maia, 2006).

Procuramos, nesse percurso, identificar algumas relações entre as representações mediáticas, em particular o papel complexo do jornalismo, a política, a democracia e o desenvolvimento dos direitos da cidadania. Vamos sumarizar agora algumas observações, procurando fazer um balanço dos resultados que julgamos ter alcançado e avançar algumas interpretações gerais.

\section{Representações, retórica e comunicação}

As representações, num sentido geral, podem ser consideradas processos de substituição de objetos por diversos tipos de símbolos e 
discursos, por meio dos quais os seres humanos tomam consciência dos objetos do mundo empírico ou imaginário, pensam sobre eles, além de utilizá-los para se relacionarem com outros seres humanos. $\mathrm{Na}$ construção das representações estão envolvidos processos cognitivos individuais (representação mental), as influências da cultura e da estrutura social, a ação dos meios de comunicação e, por fim, discute-se que as representações teriam um caráter distribuído por cada uma dessas instâncias, pessoas e artefatos culturais.

A retórica é uma forma de representação estruturada discursivamente, seja pela construção de argumentos - que chamamos de persuasão -, seja pela evocação de emoções - que denominamos sedução -, a fim de obter a identificação e apoio de outras pessoas para uma determinada causa ou projeto. As peças retóricas, por meio das quais os fatos são representados, confrontam-se publicamente, numa luta simbólica, que influencia a direção do pensamento das pessoas, integrando, em seguida, os processos pelos quais as sociedades debatem problemas, definem situações, constroem hierarquias de valores e tomam decisões políticas.

Ao longo do século XX, os meios de comunicação ganharam enorme importância como produtores e disseminadores de representações e definições de realidade para amplas audiências. As sociedades humanas tornaram-se largamente dependentes desses meios para construírem sua imagem do mundo, para se posicionarem perante questões, para se orientarem. Na política, os meios aparecem enquadrando situações, representando acontecimentos para a sociedade, de modo a situá-los numa constelação de valores, ideologias, interpretações e imaginários que serão utilizados como referências para o pensamento e julgamento pelas pessoas. No entanto, alegou-se que a disseminação das representações na sociedade contemporânea, trazendo novas possibilidades expressionais, teria posto em crise o conceito ao viabilizar a construção de simulacros, elidindo as fronteiras entre a realidade e sua imagem.

As crises políticas do primeiro governo do PT, com a disseminação de interpretações discordantes pela mídia, confundindo as audiências em controvérsias, revelações e ocultações de crimes, 
parecem constituir um momento de exacerbação dos simulacros, a partir dos quais a realidade de um delito depende da capacidade de exibição de fotos ou gravações que o revelem ou desmintam, bem como sua importância varia conforme o tempo e o espaço que os meios dedicam a essas narrativas.

Essa circunstância, no contexto da fragmentação epistemológica que caracteriza o contexto da pós-modernidade, destaca a urgência de uma crítica mediática capaz de devolver uma relativa positividade à noção de representação. Assim, a análise das representações mediáticas, numa perspectiva de leitura crítica dos meios ou de media literacy, aparece como um caminho necessário à busca da racionalidade no debate público e uma condição para a deliberação democrática. Habilidades críticas não são necessárias apenas a especialistas ou profissionais de Comunicação, mas vem-se insistindo na importância delas na educação formal, para o exercício pleno dos direitos da cidadania.

Destacamos dois conceitos correntes na bibliografia, capazes de contribuir para a crítica da comunicação jornalística: o agendamento e o enquadramento. Pelo primeiro deles, podemos identificar uma correspondência entre a ordem de importância que os leitores atribuem às questões públicas correntes não necessariamente de acordo com a sua relevância ou urgência reais, mas sim com a hierarquia da apresentação desses temas nos jornais. Já o conceito de enquadramento permite uma análise qualitativa das reportagens jornalísticas, em busca de uma "retórica implícita" nos textos, que pode ser identificada na escolha e repetição de palavras, expressões, ênfases e atenuações linguísticas, seleção das fotos, sentidos latentes nos elementos visuais que, sutilmente, conferem saliência a um ponto de vista sobre o assunto enfocado.

\section{Democracia, mídia e cidadania}

Para a sociedade brasileira, o lento e doloroso processo de superação do regime militar, ao longo de duas décadas de avanços e retrocessos, conferiu um significado especial à democracia, como 
reconquista do Estado de Direito, pela devolução do poder político aos civis. O contraste com a experiência vivida dos anos de chumbo destacou o valor das eleições diretas para todos os cargos, das garantias individuais, das liberdades públicas, de expressão e de imprensa, de organização partidária, da independência da justiça e do direito de ir e vir, entre outros. Não bastasse essa aversão peculiar à via autoritária, em decorrência da experiência vivida pelas sociedades brasileira e de outros países vizinhos, o fim dos regimes comunistas de partido único (ocorrido de forma geralmente pacífica, como resultado de pressões de movimentos populares nacionais) nos anos 1990 foi um golpe profundo na esperança de que utopias autoritárias possam representar o caminho para a felicidade coletiva. Ou seja, sociedades que viveram sob ditaduras, de direita ou de esquerda, não têm saudades do passado e valorizam mais do que tudo a democracia, seja como um fim em si mesma, seja como meio para poderem avançar em direção a outras realizações. Os problemas dos governos democráticos, como ineficiência, corrupção, incapacidade para eliminar as desigualdades e a miséria, por um lado, mostram as imperfeições desse regime, mas por outro não permitem condená-lo, porque ele constitui, justamente, o único regime que admite a correção dos erros, pela crítica e alternância no poder por escolha popular, enfim, a mudança, o aperfeiçoamento.

A democracia não significa apenas eleições, mas a existência de disputa eleitoral é essencial para normatizar o acesso universal ao poder político. Esse mesmo princípio procedimental, longe de fixar apenas um método administrativo de circulação das elites, implica o reconhecimento de uma sociedade dividida (os partidos são a expressão dessa divisão), a existência de conflitos de diversas naturezas, em suma, concepções diferentes das questões públicas, das prioridades e das soluções para os problemas destacados. Ou seja, eleições - mais do que o momento para a apresentação das pretensões políticas pessoais dos candidatos - expressam o dissenso tácito na sociedade e criam os instrumentos, os limites e as formas para sua expressão simbólica.

Depois dessa discussão sobre as dimensões do conceito de democracia, o foco da segunda parte do livro recaiu no papel desempenha- 
do pela comunicação na sua implementação, tema de controvérsia histórica entre as vertentes liberal e crítica. A primeira considera que os meios são elementos essenciais à existência e funcionamento do regime democrático, argumentando que os meios de comunicação jornalísticos têm um papel específico e insubstituível, enquanto a tradição crítica defende que os meios estão corrompendo as bases desse regime político. A avaliação negativa da tradição crítica enfatiza o caráter oligárquico da propriedade dos meios, que os levaria a agendar prioritariamente temas de interesse dos grupos econômicos estabelecidos, enquadrando de forma negativa as ações contrárias a esses interesses, ou seja, usando o espaço de representação próprio dos meios para destacar os temas de forma interessada.

Sugerimos uma forma de superação dessa antinomia por meio do conceito de hegemonia, a partir da qual podem se dar condições para um equilíbrio dinâmico entre pressões contrárias, criando no âmbito mediático um espaço de dissenso e tensão nas sociedades democráticas, que impediria a visão monolítica de uma classe. Assim, a democracia implicaria o reconhecimento da existência de conflitos reais (políticos e econômicos), que se expressam por meios simbólicos, retóricos e discursivos, processo do qual fariam parte os meios de comunicação. Imaginamos, por conseguinte, que os meios de comunicação, num contexto hegemônico capitalista, possam, a partir das pressões de classes ou de segmentos diferentes da sociedade, constituir o próprio espaço público mediatizado, capaz de viabilizar a interlocução, o debate, no âmbito da sociedade civil. No entanto, esse espaço é sempre objeto de um questionamento e não um lugar estático, de modo que o valor da tradição crítica está exatamente em salientar os estreitamentos, os oligopólios e manipulações, e reivindicar novas configurações, de modo a ampliar o número e o volume das vozes discordantes das maiorias.

De forma semelhante, a questão da cidadania foi examinada a partir de seus pressupostos normativos - do dever ser - e em termos críticos - da situação histórica concreta. Se a primeira é passível de uma crítica por estar marcada por declarações formais, essencialistas, derivadas de certos postulados apriorísticos, no entanto, ela serve de 
referência para os objetivos valorizados, ou seja, de critério para a avaliação das conjunturas históricas. A visão crítica, por outro lado, realiza a correção de uma conceituação otimista, mostrando que, especialmente no caso dos direitos sociais, os meios de comunicação não apresentam sempre uma abordagem neutra, mas tendem a enfatizar a perspectiva dos jornalistas (ou seja, da classe média) ou dos proprietários (ou seja, capitalistas). Apesar disso, é possível observar a presença crescente de reportagens sobre direitos de cidadania no noticiário, o que mostra que os meios de comunicação, também nesse caso, são um campo de tensões e de pressões cruzadas e que podem desempenhar um papel relevante na ampliação e universalização dos direitos da cidadania, dependendo para isso de processos sociais que vão além das redações, envolvendo a opinião pública, o processo político, os movimentos sociais, as transformações econômicas. Em última análise, o jornalismo é visto como parte de um processo histórico englobante, sobre o qual pode exercer alguma influência, sendo ao mesmo tempo influenciado por outros atores e instituições, num jogo complexo que se desenrola por meio de ações e reações e não pela força de um único princípio. Os meios noticiosos não podem, portanto, ser considerados determinantes do processo democrático em uma sociedade, pois eles próprios dependem das instituições democráticas para atuarem com liberdade, situação em que passam a ter um papel nos desenvolvimentos políticos. Essa é uma conclusão semelhante àquela de Schudson (2003 e 2003a), para quem notícias e suas instituições existem mesmo onde não há democracia, argumentando que as notícias "têm pouco a ver com a democracia política, a menos que o Estado inclua ou tolere um grau de autogoverno e crítica do poder do Estado" (2003 a, p.197).

\section{Representações jornalísticas do processo democrático brasileiro}

A ação da política pode ser considerada em duas modalidades distintas: a propaganda política (mais especificamente, a propaganda eleitoral) e o jornalismo político, embora haja manifestações 
confundidas de ambas. A propaganda política como retórica propriamente dita, ou seja, representações da realidade elaboradas, tem por finalidade imediatamente reconhecível conquistar apoios políticos e eleitorais, seja com base em argumentos, constituindo a persuasão, seja por identificações emocionais, a que chamamos sedução.

No entanto, o jornalismo político forma um conjunto peculiar de representações da realidade, devido à cobrança de um compromisso ético-normativo com a referencialidade neutra em relação ao mundo social, que levou Cook (2005) a considerá-lo como uma autêntica instituição política. As reportagens jornalísticas suscitam credibilidade, dados os pressupostos protocolos profissionais que presidiriam as tarefas de apuração, reportagem e redação. Essa é a percepção da audiência ou dos leitores, embora, como referimos anteriormente, o trabalho jornalístico caracteriza-se pelo agendamento e enquadramento dos acontecimentos e não por ser um mero reflexo da realidade. $\mathrm{O}$ jornalismo, de forma semelhante à retórica, tem um papel importante na construção de cenários de representação da política, especialmente pelas redes de televisão, sendo, eventualmente, capaz de influir nos processos eleitorais, momento em que os candidatos mais identificados com os cenários hegemônicos têm mais chances eleitorais do que os demais (Lima, 2001).

Ainda assim, para ser aplicado às diferentes circunstâncias das eleições brasileiras de 1989 a 2006, o conceito de cenário de representação da política solicita percursos interpretativos próprios em diferentes momentos. Se nas eleições de Collor e de Cardoso a análise do agendamento e dos enquadramentos jornalísticos da Rede Globo pode indicar que a rede construiu cenários favoráveis aos eleitos, a indefinição sobre o candidato predileto, em 2002, levou à construção de um cenário de incerteza, que não beneficiava nenhum candidato em particular, sendo, antes, favorável à competitividade da disputa eleitoral. Já em 2006, os meios atuaram intensamente na divulgação dos problemas de corrupção envolvendo personagens do governo Lula, sem criar um obstáculo à sua releição.

A série de reportagens sobre os problemas do governo, no período que antecedeu as eleições, gerou controvérsias entre diversos 
observadores e analistas sobre o papel dos meios noticiosos. De um lado, há um entendimento de que os meios adotaram uma abordagem preconceituosa em relação ao governo Lula, acentuando os problemas, antecipando condenações, ao mesmo tempo em que davam pouco destaque à importância das realizações. De outro lado, há as condenações e críticas ao governo, feitas pelos próprios autores dos textos jornalísticos, geralmente colunistas dos meios de comunicação, editorialistas e autores das reportagens. Nas publicações impressas também apareceu essa controvérsia, caracterizando um confronto entre legitimidade e legalidade: enquanto alguns veículos defendiam o governo e as ações de Lula, com base em seu grande apoio popular, outros cobravam uma conduta republicana dos integrantes do seu governo.

Identificamos diversas formas pelas quais os meios de comunicação atuaram na fiscalização do governo Lula. Apesar das alegações de que a cobertura dos meios foi uma forma de ação política contra o governo do PT, é importante lembrar que, na maioria das vezes, a divulgação dos fatos depreciativos ao governo geralmente secundou denúncias surgidas entre aliados ou de atuações de instâncias do próprio Estado, como de um parlamentar da base aliada, do Judiciário, do Ministério Público, da Polícia Federal. Essas instituições, aliás, têm poder de fato nessas situações, enquanto a imprensa tem exclusivamente o poder simbólico de comunicar-se diretamente com a opinião pública, constituindo, por essa via tão somente uma força de pressão indireta sobre o governo.

Apesar da quantidade de notícias desfavoráveis ao governo divulgadas pelos meios noticiosos, especialmente em decorrência dos casos do "mensalão", em 2005, e do "dossiê" contra José Serra (candidato ao governo de S. Paulo), em 2006, Lula, na nossa interpretação, teve condições de atuar na construção do CR-P em 2006 por diversos motivos: a) por ser o candidato com maior visibilidade mediática dada sua condição de presidente em exercício, b) o que também lhe conferia status político mais alto, além de ele ser c) o único candidato com experiência administrativa de presidente, d) por causa dos sucessos na economia e e) pela implantação políticas 
sociais de grande cobertura populacional. A ação simbólica das políticas de caráter popular implantadas pelo governo federal foi decisiva para a construção do cenário, não pela influência difusa da comunicação mediática convencional (imprensa, radiodifusão), mas por meios que interpelam os interesses dos eleitores diretamente, por intermédio de políticas sociais que são, simultaneamente, materiais (concretas) e simbólicas, capilarizadas na sociedade por meio das famílias beneficiadas.

A conjuntura peculiar da reeleição de Lula negou, portanto, a crença na força da influência irresistível dos meios de comunicação convencionais sobre a sociedade, mostrando como medidas de natureza econômica e social, além de sua materialidade tangível, constituem símbolos poderosos que participam da construção do cenário de representação política, atenuando o poder dos meios tecnológicos.

\section{Perspectivas de trabalhos futuros}

Ao concluirmos este livro, procuramos aplicar as contribuições teóricas na identificação de problemas e realização de análises, mas também acreditamos vislumbrar um horizonte de estudos futuros das relações entre os meios e as dinâmicas sociais e políticas.

Especificamente, é preciso aumentar nosso conhecimento sobre o poder e influência do jornalismo no processo democrático brasileiro por meio de estudos que combinem análises das conjunturas políticas às análises de enquadramento dos fatos pelos meios noticiosos, acompanhando os desdobramentos efetivos que possam ter sido provocados pelo jornalismo.

De forma similar, é importante examinar o papel dos meios na defesa dos direitos da cidadania e na conquista de novos direitos. Destacamos neste enfoque a relevância de estudar o agendamento e os enquadramentos construídos sobre os movimentos sociais e sobre os problemas sócio-econômicos, políticos e jurídicos, tais como a distribuição de renda, moradia, acesso à educação, à saúde, segurança e igualdade racial e de gênero, os direitos das criança e do 
adolescente. A análise dos enquadramentos do jornalismo sugere que a atenção a esses temas não é incompatível com a organização empresarial dos meios, voltados para o mercado, e que se trata mais de uma questão de pautá-los sistematicamente, mantendo o foco no papel social e político do jornalismo.

Esses temas para investigação dão uma ideia do imenso campo de estudos das relações entre comunicação, democracia e cidadania que vimos estudando em nosso grupo de pesquisa a partir de 2007. Tratase de temas que abordam as questões sociais de forma transversal, articulando as abordagens da Comunicação à Sociologia, à Ciência Política e ao Direito, num empreendimento multidisciplinar, que visa pôr em evidência o papel da Comunicação (em particular, do jornalismo) nos processos sociais ampliados e no aprimoramento da esfera pública democrática brasileira.

\section{Referências bibliográficas}

COOK, T. E. Governing with the news: the news media as a political institution. Chicago/Londres: The University of Chicago Press, 2005.

LIMA, V. A. Mídia, teoria e política. São Paulo: Fundação Perseu Abramo, 2001.

MAIA, R. Política deliberativa e tipologia de esfera pública. In: ENCONTRO DA ASSOCIAÇÃO NACIONAL DE PÓS-GRADUAÇÃO EM COMUNICAÇÃO - COMPÓS, 15, 2006, Bauru. Anais... Bauru: COMPÓS, 2006. 1 CD-ROM.

SCHUDSON, M. The sociology of news. Nova Iorque: Norton, 2003.

The power of the news. Cambridge/Londres: Harvard University Press, 2003a. 


\author{
SOBRE O LIVRO \\ Formato: $14 \times 21 \mathrm{~cm}$ \\ Mancha: 23,7 x 42,5 paicas \\ Tipologia: Horley Old Style 10,5/14 \\ 1 a edição: 2009 \\ EQUIPE DE REALIZAÇÃO \\ Coordenação Geral \\ Marcos Keith Takahashi
}




\section{CULLURA \\ ACADÊMICA}

Editora 